Historic, Archive Document

Do not assume content reflects current scientific knowledge, policies, or practices. 

69.63
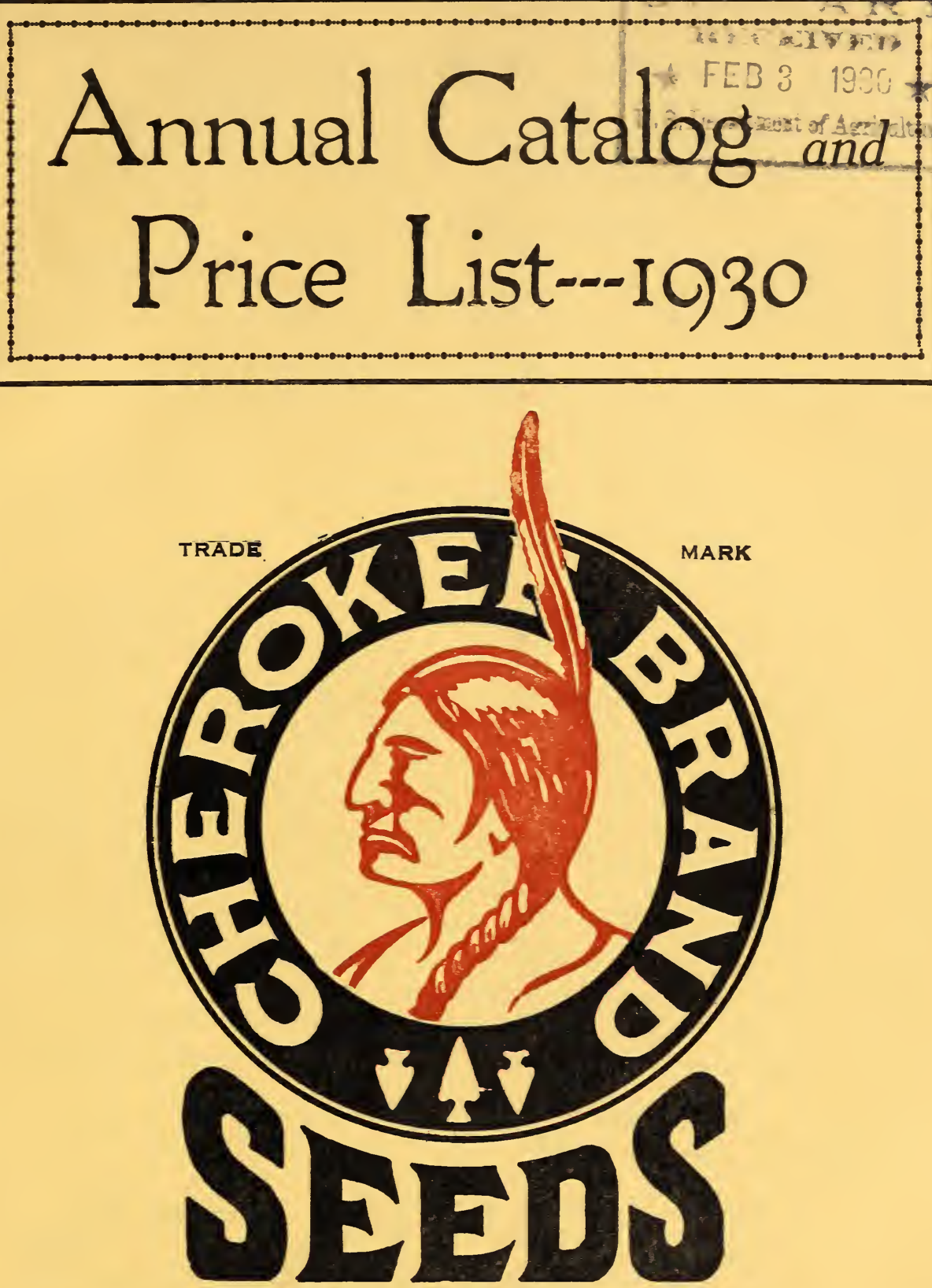

Asheville Seed Company Asheville, North Carolina COLLEGE STREET AT LEXINGTON AVENUE 


\section{Grove Park Evergreen Lawn Grass}

The basis of Grove Park Lawn Mixture is Kentucky Blue Grass to which is added White Dutch Clover and a number of quick growing and valuable fancy grasses which produce a green turf much sooner than can be obtained by blue rrass alone. Providing the soil is not sour, and is properly and thoroughly fertilized, the blue

\section{Shady Park Lawn Grass}

Few grasses grow well in shaded portions of awns or groves, hence it is necessary to sow a mixture of grasses which are adapted for growing in the shade. Our Shady Park Mixture is composed entirely of choice clean seed of the finest and most costly grasses which have been rrass will eventually take entire possession. In the meantime a good looking lawn is obtained while the blue grass, which is slow to germinate, is getting established. Lime and Fertilizers are described on page 49 and back cover.

Postpaid, lb. 50c; 5 lbs. $\$ 2.15 ; 10$ lbs. $\$ 4.05$.

Not Prepaid, lb. 40c; 5 lbs. $\$ 1.90 ; 10$ lbs. $\$ 3.70$.

found to thrive in shaded locations and it pro duces an abundant and even growth of beautiful grass.

Postpaid, lb. 60 c; 5 lbs. $\$ 2.65 ; 10$ lbs. $\$ 5.05$.

Not Prepaid, lb. 50c; 5 lbs. $\$ 2.40 ; 10$ lbs. $\$ 4.70$.

\section{How To Secure PREPARATION OF SEED BED}

A fine lawn requires a rich, well drained soil. All weeds, roots and other debris should be removed and the soil spaded to a depth of eight or ten inches, and thoroughly pulverized like garden soil for the reception of small seed. Large areas can be plowed and disked, but the soil should be thoroughly pulverized before the seed is sown.

\section{FERTILIZATION}

Grass seed send out long feeding roots which absorb a large quantity of plant food in making heavy green turf. It is necessary to mix fertilizer to the depth of eight or ten inches to supply this plant food. The class of fertilizer used will have a direct bearing on the finished lawn. To avoid numerous noxious weeds that lways come by the use of fresh manure, we advise fertilizing your lawn with Pulverized Sheep Manure, a natural fertilizer, free from all weed seed. Ground Bone Meal is also valuable as an enricher of lawns and a top dressing. Bone Meal or Sheep Manure, or a mixture half of each, should be applied at the rate of 30 lbs. for 300 square feet. As a top dressing, $18 \mathrm{lbs}$, to 300 square feet.

Vigoro is a well balanced, high grade fertilizer, that has given excellent results in building lawns; it is especially valuable in building new lawns. Use 4 lbs. to 100 square feet. As top dressing 2 lbs. to 100 square feet.

Ants, which frequently infest lawns, can be driven off by the use of Tobacco Dust, which is also a good fertilizer, or by using Antrol described on page 50 .

\section{A Beautiful Lawn}

\section{LIMING THE SOIL}

When the soil is excessively acid it will be found necessary to lime the land. Lime sweetens the soil and in addition liberates plant food and makes a clay soil easier to work. Lime is listed on page 49 .

\section{SOWING THE SEED}

For spring sowing, Lawn Grass Seed should be sown as early as possible, from February to May, or if in the fall, from September to the last of November. Many people follow the practice of sowing lawn grass seed on top of snow with very great success. As the snow melts, the seed is carried to the proper depth. Thick seeding gives the best results. It should be sown at the rate of $1 \mathrm{lb}$, to 250 square feet or $150 \mathrm{lbs}$. to an acre. The seed should be carefully and evenly sown, lightly raked in, and afterwards, provided the soil is not too wet, rolled or made firm by patting down with the back of a spade. This packing brings the seed in close contact with the soil and prevents drying out; it also gives a quicker and a more even germination.

Lawns should not be neglected. The grass should be kept cut, rolled if necessary, and watered in dry weather, bare spots reseeded and weeds dug out as fast as they appear. Please see back pages of this catalog for Lawn Mowers, Rollers, Weed Pullers, Tools, and Fertilizers.

\section{Cherokee Garden Hose}

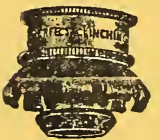

HOSE

COUPLINGS

Postpaid, pair 35c.

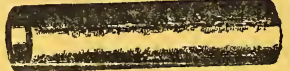

CHEROKEE GARDEN OR LAWN HOSE-A 5-8 inch sunproof red rubber hose that wont kink. Best grade of rubbed used and No. 10 hard finish flsh net twine instead of soft cotton; couplings included but nozzle is extra.

Price, $15 \mathrm{c}$ per $\mathrm{ft}$.

\section{Rainbow Hose Nozzle}

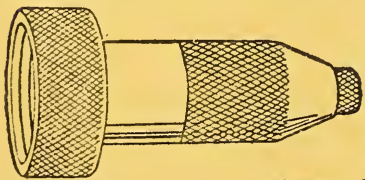

This Nozzle runs on a hard fibre washer which absorbs water and eliminates all wear and leaks. Gives either a full or soft stream or fine spray and a positive shut off.

Postpaid, 85c: Not Prepaid, 75c
Rainbow Lawn Sprinkler

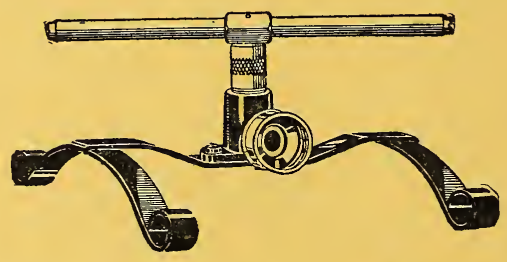

Revolves rapidly on any pressure. Wearing and friction almost eliminated by use of water absorbing fibre washers. Made of Brass. Will not stick or corrode. Distributes about $5 \mathrm{gal}$ lons of water per minute evenly over every portion of ground, 20 feet from sprinkler. Will indefinitely, without repair or attention, do the work it was built for. A lasting source of satisfaction at a fair price.

No. 5-Stands 4 inches high. 7 inch revolving head. Postpaid, \$2.25. Not prepaid, $\$ 2.00$.

No. $91 / 2$-Stands 36 inches high. Water discharged 6 feet in the air. Postpaid, $\$ 4.00$.

Not prepaid, $\$ 3.50$. 


\section{ORDER BLANK FOR SEEDS, ETC.}

All prices in this catalog, except where otherwise noted, are based on customer paying transportation charges. Please see page 1 for Parcel Post rates, conditions of sale, direction for ordering, sending money, etc.

\section{ASHEVILLE SEED COMPANY ASHEVILLE, N. C.}

\section{Please Do Not Write Here}

Date Received

Date Filled

Filled $\mathrm{By}$

Shipped By

Order Number.

\section{Amount Enclosed}

Check

P. O. Money Order

Exp. Money Order

Cash.

Stamps

County

State

R. F. D

Express or Freight Office

(If different from Postoffice)

ASHEVILLE SEED COMPANY gives no warranty, express or implied, as to description, quality, productiveness, or any other matter, of any seeds, bulbs or plants they send out and they will be in no way responsible for the crop. If the purchaser does not accept the goods on these terms, they are at once to be returned, money will be refunded and no sale has been made.

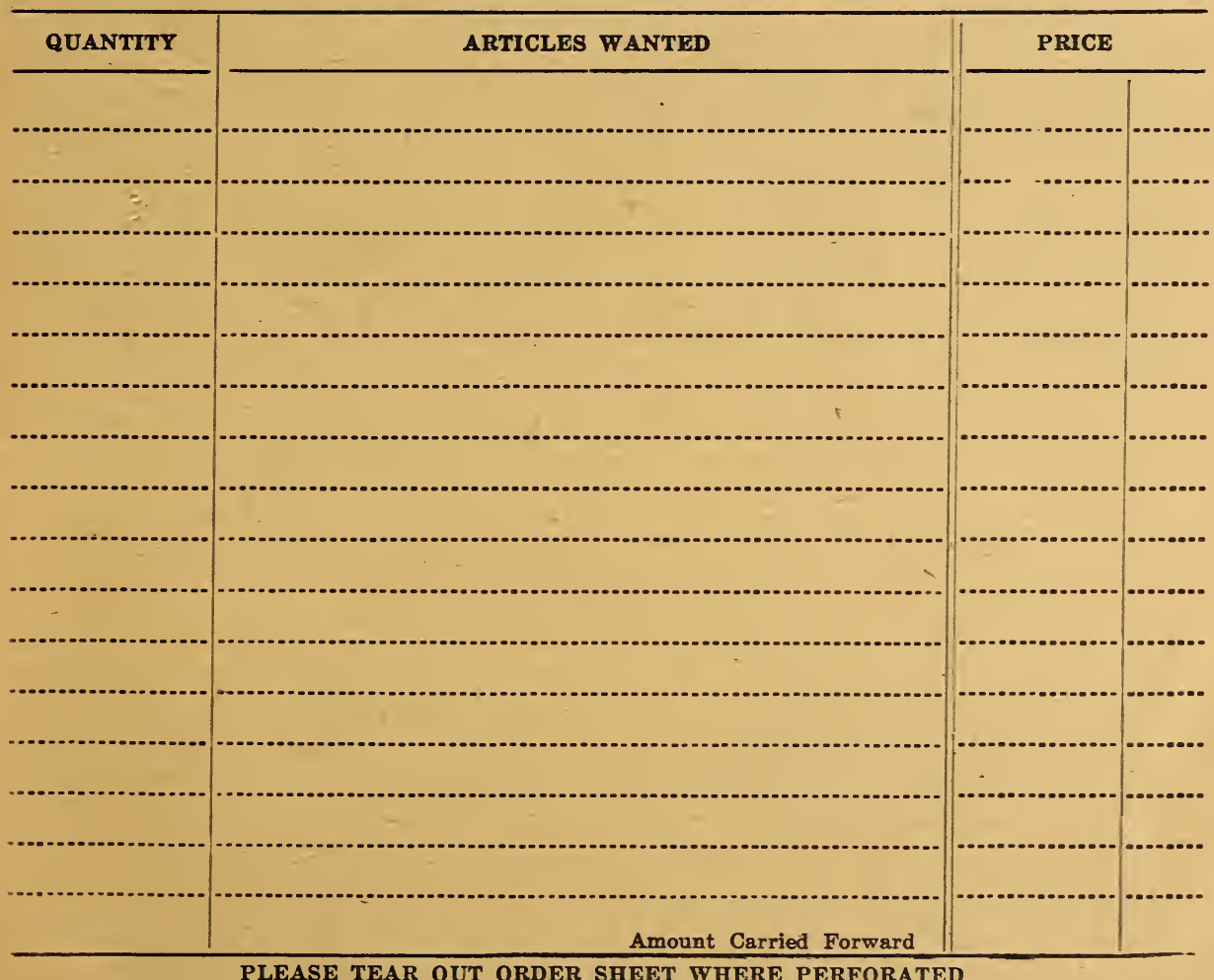


PRICES SUBJECT TO CHANGE WITHOUT NOTICE

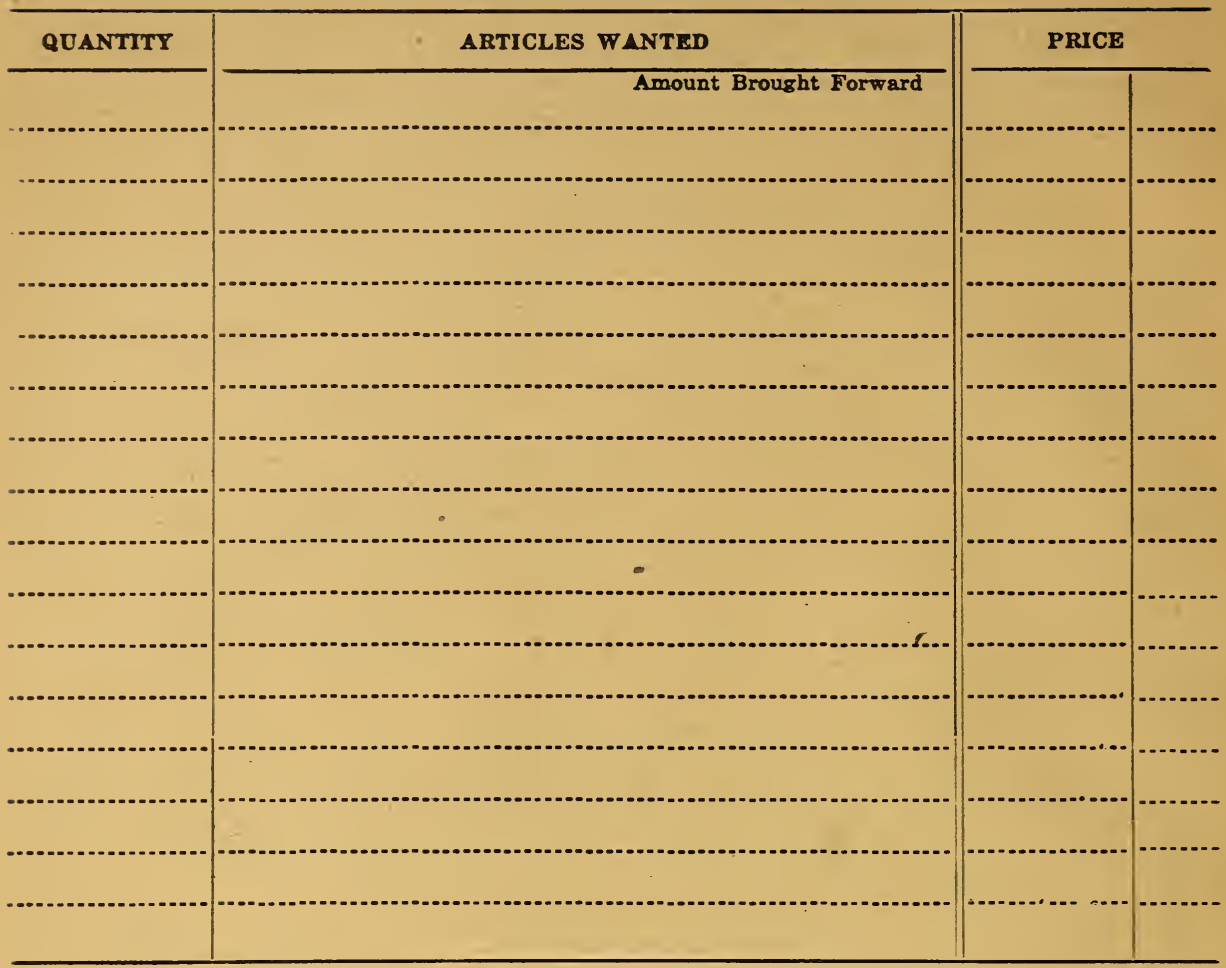

Bỳ carefully checking this list before sending your order, a great saving may be made in transportation cost, and you may also find that an important and an immediate necessity has been omitted.

$\begin{array}{llll}\text { Garden Seed } & \text { Lawn Seed } & \text { Insecticides } & \text { Garden Tools } \\ \text { Flower Seed } & \text { Bulbs } & \text { Fungicides } & \text { Orchard Tools } \\ \text { Field Seed } & \text { Fertilizers } & \text { Dusting Materials } & \text { Lawn Tools } \\ \text { Poultry Supplies } & \text { Incubators } & \text { Sprayers } & \text { Feeds, Etc. }\end{array}$

Kindly list below the names of any friends whom you think would be interested in receiving our catalog.

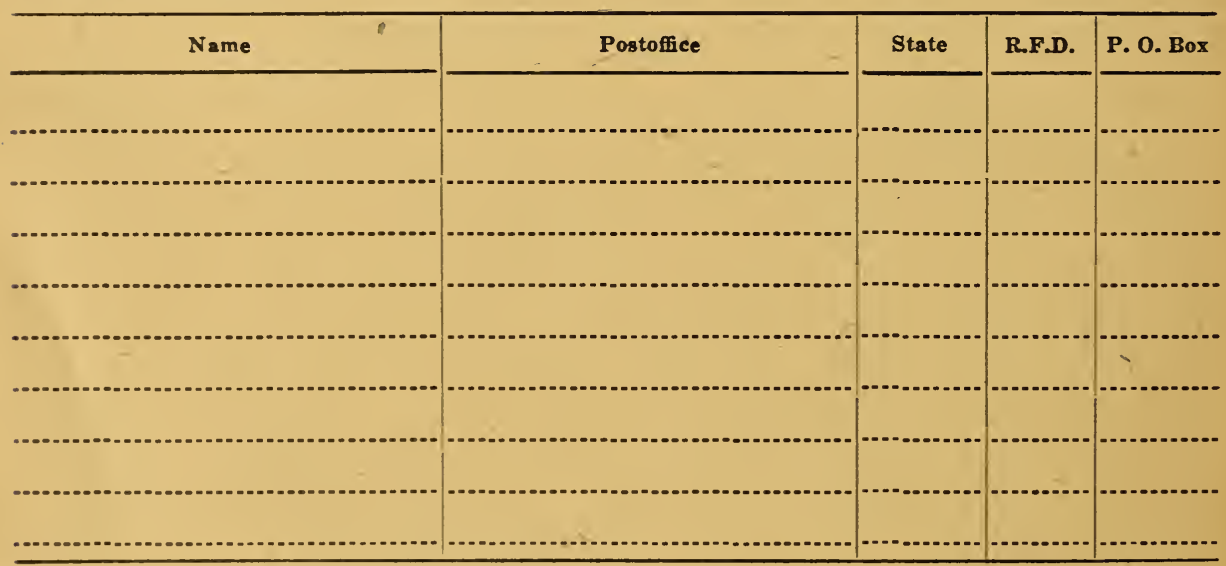




\section{DIRECTIONS FOR ORDERING [INFORMATION ]}

CONDITIONS OF SALE-All quotations are ubject to market changes and goods being unsold on receipt of order. Asheville Seed Co. gives no warranty, express or implied, as to description, quality, productiveness or any other matter of any seeds, plants or bulbs they send out, and they will be in no way responsible for the crop. If the customer does not accept the goods on these terms, they are at once to be returned, money will be refunded and no sale has been made.

ORDER EARLY-Do not delay ordering until you are ready to use the seeds or goods you want. The inconvenience and annoyance of delayed shipments, etc., can be aroided by customers placing their orders early for all their requirements. The loss of time in planting caused by delays in receiving goods and the possibility of advances in price point to the advantage and wisdom of early buying.

HOW TO SEND AN ORDER-You will find in the front and back of this catalog an order sheet, perforated for tearing out; also an addressed envelope to send the order in. When convenient, always use this order sheet. Please do not write anything on the sheet except items wanted and what pertains to the order. Write on separate sheet asking for prices, or questions to be answered, or information given; this will avoid the possibility of being overlooked; also insure quick attention to information asked.

Please be careful to sign your Name, Street Address or R. F. D. Number, Postofice, County and State, on each letter sent us. It is a good plan to prunt or typewrite.

HOW TO SEND MONEY-Remittance should be made either by Post Office or Express Money Order, Certified Check or Bank Draft. Postage stamps in small denominations, to cover small purchases are entirely satisfactory. Always register letters containing currency. Coin should not be sent by mail.
C. O. D. SHIPMENTS-Shipping C. O. D. onb adds to the cost, as the buyer pays the expense of collection. If you prefer shipment C. O. D. please remit with your order one-half the amount of the bill. Under no circumstances will we ship perishable goods (plants, etc.) C. O. D.

POSTPAID PRICES-Mean that merchandise so quoted will be delivered postpaid to your door if you live on an $R$. F. D. route or at any post office within the first 4 zones. Please add postage when to be shipped out of 4th zone using "Not Prepaid" prices as the basis.

TRANSPORTATION CHARGES-On articles quoted "Not Prepaid" customers pay the freight or express charges. If goods quoted "Not Pre.paid" are to be sent parcel post, consult the following table and add sufficient postage to your remittance to cover postage; bearing in mind that no packages may be sent through the malls weighing more than $70 \mathrm{lbs}$. and must not exceed 84 inches (length and girth combined). Shipments of seeds amounting to more than 70 lbs. therefore, must be devided and additional bags used. If remittance does not include postage on "Not Prepaid" articles to be sent Pareel Post, sufficient seed will be deducted to cover the charge. Insecticides marked "poison" can not be shipped by mail.

BAGS-On orders for quantities at prices quoted "not prepaid," of clovers, timothy, red top or herds grass, alfalfa, millet, rape, vetch, eten which must be shipped in cotton bags, we charge extra for the bags as follows: $2 \frac{1}{2}$ bu. seamless bag $35 \mathrm{c} ; 1$ bu. cotton bag $25 \mathrm{c}$; $1 / 2$ bu. size $20 \mathrm{c}$; peck size 10c. When remittance is not sufficient to cover bag charge, sufficient seeds will be da ducted to cover the cost of same. On orders for seeds in any quantity when ordered at prices quoted "postpaid" there is no charge for bags. We make no charge for bags for oats, rye, barley, field corn, cow-peas, soy beans and ouch grass seeds as can safely be shipped in burlap bags.

\section{PARCEL POST RATES FROM ASHEVILLE}

\begin{tabular}{|c|c|c|c|}
\hline $\begin{array}{l}\text { United States Parcel Post Rates } \\
\text { (Seeds, plants and bulbs included) }\end{array}$ & $\begin{array}{l}\text { First } \\
\text { pound } \\
\text { or } \\
\text { fraction }\end{array}$ & $\begin{array}{l}\text { Each } \\
\text { additional } \\
\text { pound or } \\
\text { fraetion }\end{array}$ & $\begin{array}{l}\text { Packages must not exceed- } \\
84 \text { inches (length and girth } \\
\text { combined) }\end{array}$ \\
\hline $\begin{array}{l}\text { Local Rate, Asheville } \\
\text { 1st Zone, within } 50 \text { miles of Asheville } \\
\text { 2nd Zone, over } 50 \text { and under } 150 \text { miles } \\
\text { 8d Zone, over, } 150 \text { and under } 300 \text { miles } \\
\text { 4th Zone, over } 300 \text { and under } 600 \text { miles } \\
\text { 5th Zone, over } 600 \text { and under } 1000 \text { miles_-- } \\
\text { 6th Zone, over } 1000 \text { and under } 1400 \text { miles- } \\
\text { 7th Zone, over } 1400 \text { and under } 1800 \text { miles.- } \\
\text { 8th Zone, over } 1800 \text { miles.-- }\end{array}$ & $\begin{array}{r}\$ 0.7 \\
.07 \\
.07 \\
.08 \\
.08 \\
.09 \\
.10 \\
.12 \\
.13\end{array}$ & $\begin{array}{r}30.01 \\
.01 \\
.01 \\
.02 \\
.04 \\
.06 \\
.08 \\
.10 \\
.12\end{array}$ & $\begin{array}{l}\text { Limit of weight this zone, } 70 \mathrm{lbs} \\
\text { Limit of weight this zone, } 70 \mathrm{lbs} \\
\text { Limit of weight this zone, } 70 \mathrm{lb} \\
\text { Limit of weight this zone, } 50 \mathrm{lbc} \\
\text { Limit of weight this zone, } 50 \mathrm{Jb} . \\
\text { Limit of weight this zone, } 50 \mathrm{lbs} \\
\text { Limit of weight this zone, } 50 \mathrm{lbs} \\
\text { Limit of weight this zone, } 50 \mathrm{lbs} \\
\text { Limit of weight this zone, } 50 \mathrm{lbe}\end{array}$ \\
\hline
\end{tabular}

All small Parcel Post packages, weighing 8 ounces or less can be sent at the special rate of 1 cent for each 2 ounces or fraction to all parts of the United States. (Over 8 ounces must be sent at Parcel Post rates.)

Kindly Remit for Postage when it is necessary so as to avoid delay in fllling and shipping order. 


\section{PLANTING CALENDAR for FARM and GARDEN}

\section{JANUARY}

Vegetables-Little can be put in open ground except Asparagus roots. Prepare hot beds and sow Eariy Cabbage, Lettuce, Radish, Beet, Cauliflower, and Onion.

Flowers-Sow in open ground Sweet Peas. Sow in hot beds, Pansy, Daisy, Verbena, Asters, and other Flower Seeds, for later transplanting. Fall bulbs can usually be planted.

Farm-If weather permits sow Canada Field Peas. Top dress grain, grass, and clover fields.

\section{FEBRUARY}

Vegetables-Sow in hot beds Early Cabbage, Cauliflower, Lettuce, Onion, Beets, and the middle or the last of the month, in hot beds, Tomatoes, Egg Plant and Pepper. The last of this month sow in open ground Early English Peas, Kale, Beets, Spinach, Carrots, Radish and Parsley. Set out Asparagus, Horse Radish and Rhubarb Roots, Onion Sets and Hardy Lettuce Plants; also early planting of Irish Potatoes.

Flowers-Sow in open ground Sweet Peas. In hot beds, boxes or pots inside Flowers to be transplanted later. Sow Grove Park Lawn Grass.

Farm-Sow Canada Field Peas, Oats and Dwarf Essex Rape. The middle to the last of this month grasses and clovers can be sown.

\section{MARCH}

Vegetables-This should be an active month with all vegetable growers. Sow in open ground Garden Peas for succession, Early Cabbage, Cauliflower, Spinach, Kale, Mustard, Lettuce, Betts, Carrots, Parsnips, Salsify, Early Turnips, Rhubarb Roots, Asparagus and Horse Radish Roots, and Irish Potatoes. Set out Cabbage, Cauliflower, Lettuce and other plants that you have had in hot beds after hardening them by leaving the glass open at night. Pick a warm corner and sow Herb Seed.

Flowers-Sow in open ground Sweet Peas and the hardy kinds of Flower Seed, as they will bloom earlier. The last of this month set out Tuberose, Gladioli, Cannas, Caladiums, and Dahlia Roots. Sow Grove Park Lawn Grass. Farm-Sow Canada Field Peas, Clovers and all Grasses, Spring Oats and Dwarf Essex Rape.

\section{APRIL}

Veretables-Plant Early Garden Corn, English Peas, Snap Beans, Irish Potatoes, Cabbage, Tomatoes and Lettuce in open ground for succession. Sow Beets, Carrots, Radish, Parsnips, Salsify, Parsley, Celery, Early Turnips, Kohlrabi, Collards, Mustard and Kale. Put out Onion Sets, Asparagus Roots, Rhubarb Roots. Bed Sweet Potatoes. The middle to the last of this month plant Cucumbers, Squash, Watermelons and Cantaloupes.

Flowers-Sow hardy Flower Seed; after the middle of the month, the half hardy kinds. Set out Lily. Dahlia, Canna, Tuberose and Gladioli Bulbs, Coleus, Salvia and other bedding plants. Sow Grove Park Lawn Grass Seed.

Farm-Sow Clover and Grass Seeds; Oats early in the month. Later in the month sow Mangel Wurtzel Stock Beets, Field Corn, etc.

\section{MAY}

Vegetables-Nearly all tender seeds can be sown this month; also for succession sow Carrots, Beets, Parsley, Radish, Brussels Sprouts, Parsnips, Salsify. Plant Pole, Bunch, Snap and Lima Beans, Garden Corn, Okra, Squash, Cucumber, Cantaloupe, Watermelon and Pumpkin. Sow now Late Cabbage and Cauliflower Seed to make plants for fall. Set out Tomatoes, Pepper and Egg Plants.

Flowers-Vine Seed for shade, all floral Bedding Plants, Tuberose, Gladioli, Cannas, Dahlias and other Bulbs can be planted out successfrlly. Sow Grove Park Lawn Grass Seed.

Farm-All the Sorghums, Millets, Cow Peas, Soy or Soja Beans, Field Corn, Mangel Wursel Beets for winter feeding, etc.
JUNE

Vegctables-Plant Collards, Okra; Bunch and Late Pole, Snap and Lima Beans, Late Peas, Cucumbers, Squash, Turnips, Garden Corn; for succession, Late Potatoes, Radish and Beets. Set out Tomatoes, Cabbage, Egg Plants, Pepper. Sweet Potato Plants.

Flowers-Nasturtiums and other Flower Seed for fall and winter use; Vine Seed for shade; Coleus, Salvia and other Bedding Plants.

Farm - Sow Millet, Sudan Grass, Sorghums, Cow Peas, Soy Beans, Navy Beans. Plant Late Corn, Pumpkins and Watermelons.

\section{JULY}

Vegetables-Set out Cabbage, and Celery Plants for fall and winter use. Plant Snap Beans for succession, and Sugar Corn for late roasting ears. Sow Rutabagas and early varieties of Turnips, Lettuce, Mustard, Collards, Kohlrabi. Plant Cucumbers for picking and table.

Flowers-Plant Nasturtiums for late blooming; keep all plants well watered; use a sprinkler on your lawns.

Farm-Sow Crimson Clover at the last working of your corn. Buckwheat can be sown for bees, forage, an improver of the soil, and grain. Sow Cow Peas and Soy Beans; these are improvers of the soil and fine hay crops; also for early hay or fodder sow Millet, Sudan Grass and Cane.

\section{AUGUST}

Vegetables-Sow Cabbage and Lettuce for fall heading; set out Cabbage and Celery Plants; continue planting Snap Beans for succession. Early English Peas planted this month will give a good fall yield. Sow winter varieties Radish, Turnips, Rutabagas, Spinach, Kale, Mustard, Endive, Collards, Parsley, and Onion Seed.

Flowers-Make first planting of Pansy, Daisy and other perennial flower seeds. Keep all plants well watered.

Farm-Crimson Clover should be sown in every available place. It is a great enricher of the soil, and makes very nutritious feed. Rye and Barley should be sown for fall and winter grazing and afterwards will make a crop of grain. Alfalfa can safely be sown. Towards the end of the month, sow Hairy Vetch, Dwarf Essex Rape, Grasses and Clovers.

\section{SEPTEMBER}

Vegetables-Sow Winter Radishes, Spinach, Turnips, Mustard, Parsley, Kale, White Silverskin and other Onion Sets.

Flowers-Hyacinths, Tulips, Narcissus and other Bulbs can be planted this month; also Pansy and other perennial flower seeds. Sow Grove. Park Lawn Grass Seed.

Farm-Sow all kinds of Grasses and Clovers and Hairy Vetch. Crimson Clover should by all means be sown, as it makes fine winter grazing and is a great soil improver. Continue to sow Winter Rye and Winter Barley for early grazing crops as well as for grain: Dwarf Essex Rape for sheep, pigs, and poultry. Oats this month get well rooted before spring.

\section{OCTOBER}

Vegetables-Sow early sorts of Cabbage, Turnips, Spinach, Kale, Mustard ; set out Asparagus Roots and all varieties of Onions Sets.

Flowers-Plant Hyacinths, Narcissus, Tulips, and other Bulbs. Sow Pansy and other perennial flower seeds. Fall seeding of lawn frequently does better than spring. Sow Grove Park Lawn Grass Seed, and fertilize with Vigoro or with Bone Meal and Sheep Manure.

Farm-This is the month to sow Wheat, Winter Oats, Rye, Barley, Vetch and Rape. The earlier you can get in your Grasses and cover crops the better. 


\section{PLANTING CALENDAR (Continued)}

\section{NOVEMBER}

Vegetables-Hot beds or cold frames should be made to sow Lettuce and early varieties of $\mathrm{Cab}$ bage; set out Onion Sets, Asparagus Roots, Rhubarb and Horse Radish Roots. Spinach can be sown early in the month.

Flowers-Hyacinths, Tulips, Daffodils, Crocus, and other flowering bulbs should be planted. Grove Park Lawn Grass Seed can usually be sown early in the month; using Bone Meal as fertilizer.

Farm-Sow Rye on all vacant places; it makes a fine winter cover and grazing crop. Sow Wheat, Barley, Vetch, Rape and Grasses.

\section{DECEMBER}

Vegetables - In hot beds, sow Lettuce and Cabbage. Beets and Radish can be forced in hot beds for winter use as well as Lettuce which often proves very profitable. In open ground set out Asparagus, Rhubarb and Horseradish roots.

Flowers-This month Hyacinth, Tulips, Daffodils, Crocus, and other bulbs should be planted. In case of snow it is a good plan to sow Grove Park Lawn Grass Seed, using Bone Meal as fertilizer on top of the snow.

Farm-Wheat and Rye can usually be sown early in December.

\section{INDEX}

Name

Alfalfa

Page

Antrol

Aphistrogen

Arsenate of Lead

Artichoke

Asparagus Seed

Asparagus Roots

Barley

Baskets

Beans, Garden - 5-6-7-8

Beans, Soy - - 47

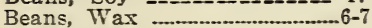

Beans, Shell

Beans, Cornfield

Beans, Lima

Beets, Garden

Beets, Stock

Birds \& Supplies_._.Back Cover

Black Leaf 40 ........................... 50

Blue Grass ……................... 43

Blue Stone (Copper Sulphate) 50

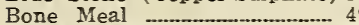

Bordeaux Mixture _............ 50

Broom Corn _.___ 45

Brooders Brussels Sprouts 60

Brussels Sprouts _-.__ 4

Buckwheat

Cabbage Seed _-............-. 10

Caladium Bulbs ......................... 29

Calcium Arsenate _-___ 50

Calf Meal _=-_-_-_-__-_-_ 64

Canada Field Peas....____ 45

Canna Roots

Cantaloupe

Caponizing Tools …_..._____ 63

Carrots, Garden _.........-..- 11

Cauliflower …-...---.---- 11

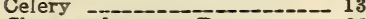

Chrysanthemum Roots ........ 28

Clovers ________ 40

Collards

Corn, Field - 48

Corn, Garden -_-_- 12

Corn, Pop _-_____ 17

Corrosive Sublimate ................. 21

Cow Ease …............................ 50

Creeping Bent Grass................. 43

Cress

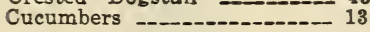

Dahlia Roots …....................... 28

Directions for Ordering............ 1

Dog Feed ___

Don Sung

Dowco

Dry Lime Sulphur ……........... 50

Egg Plant .......................... 14

Endive ……………-.............. ${ }^{14}$

Fern Stands .....................................63

Fertilizers …............................. 49

Fescue, Sheep's …………-....... 43

Fescue, Meadow ...................... 43

Fescue, Red or Creeping......... 43

Field Seeds …........................40-44
Name

Fish Oil Soap

Flower Boxes

Flower Pots

Flower Seed

Fly Death

Forage Crops

Fungicides

Garden Plows \& Cultivators 53

Glass Cloth .................Back Cover

Gladioli Bulbs

Back Cover

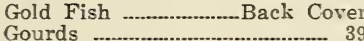

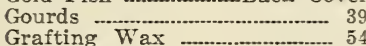

Grape Dust

Grass Catcher

Grass Hook

Grass Seeds ……………..........42-4

Grogreen

Herbs ..................... 22

Horse Radish Roots ……....... 14

Hose, Garden ….............. Cort

Hose, Nozzel .............Front Cover

Incubators

Inoculation

Insecticides

Insectrogen

Iris Roots

Kale

Kohlrabi -

Labels, Wood - 63

Lawn Grass Seed...Front Cover

Lawn Mowers _______ 58

Lawn Rollers

Leg Bands ............................. 63

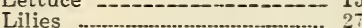

Lily of the Valley .................... 29

Lime, Hydrated

Magnesium Arsenate _-_.-- 50

Melons, Musk _.......... 16

Melons, Water _._. 17

Millet ---_-_-_-_-_-_-_---- 45

Mustard ........ 18

Nasturtiums _._._-_._-_-_ 85

Nest Eggs ……....................... 63

Nitrate of Soda _..._._. 49

Oats

Oat Sprouters …...................... 63

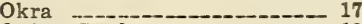

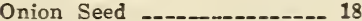

Onion Sets -

Orchard Grass -

Para Dichlorobenzine -... 50

Parsley 19

Parsnips - 19

Parsnips Mixture -

Peas, Garden _-_ 20

Peas, Field or Cow________ 17

Peat Moss …_.................... 19

Pepper Roots

Phlox Roots ……..................... 27

Pigeon Feed
Name

Page

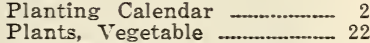

Plant Tubs ……...... Back Cover

Potatoes, Irish …………........ 21

Poultry Feed …....................... 64

Poultry Remedies ..................... 64

Poultry Punches …………-...... 63

Poultry Supplies …..............60-63

Pruning Tools ….................... 54

Pumpkin …_......................... 22

Putnam Brooders .................. 59

Rabbit Feed …….......................... 6

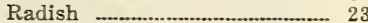

Raffia _...................................... 63

Rakes ....................................... 55

Rape, Dwarf Essex …............ 46

Rat Poison .............................. 50

Red Top ……………- 43

Rhubarb Roots …………....... 22

Roses -...-. 27

Rose Sprays ................................ 27

Rough Stalked Meadow Grass 44

Rutabaga Seed ....................... 26

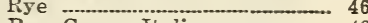

Rye Grass, Italian ............ 43

Rye Grass, Perennial or English.

Salsify

Seed Sowers …................... 63

Sheep Manure, Pulverized.... 49

Slug Shot …....................... 50

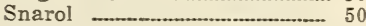

Spinach ………………-............ 24

Sprayers …............................5 51-52

Squash ……-...... 21

Stimugerm …............................ 41

Stimuplant ……............................ 49

Sudan Grass ................................. 44

Sulphate of Ammonia.............. 49

Sulpho Tobacco Soap................ 50

Sweet Peas ……….................... 37

Swiss Chard

Tall Meadow Oat Grass......... 42

Thermometers _._.n-n....... 59

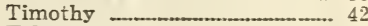

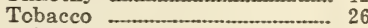

Tobacco Dust ……..........__ 49

Tomato Seed ……..................... 25

Tobacco Knife .............................. 57

Tools, Orchard, Lawn \&

Tuberose Bulbs

Turnips …..........- 26

Vermingo …………………............ 50

Vetch

Vigoro

Vine Seeds

Watermelon -......................

Water Glass …………........................... 63

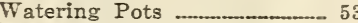

Weed Killer .................. 50

Whale Oil Soap........................ 50

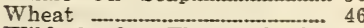

Wild Garden Flower Seed.... 38

Wood Meadow Grass......._._. 44

90-10 Dust 


\section{HIGH QUALITY VEGETABLE SEEDS}

All vegetable seeds that we offer are bought from reliable growers, are of the best strains and tharoughly tested for vitality. These seeds comprise the popular varieties that have proven successful to this section and any gardener, whether for the home or market, will find in our stock a sufficient range of selection for all practical purposes. We suggest that you consult the Planting Calendar on page 2; the pages on which are listed fertilizers, insecticides and fungicides; also those deseriblas sprayers and tools. The inoculation of bean and pea seed with Stimugerm is highly recommended as it will inerease the crop, insure an even stand and improve the condition of the soil.

\section{ASPARAGUS}

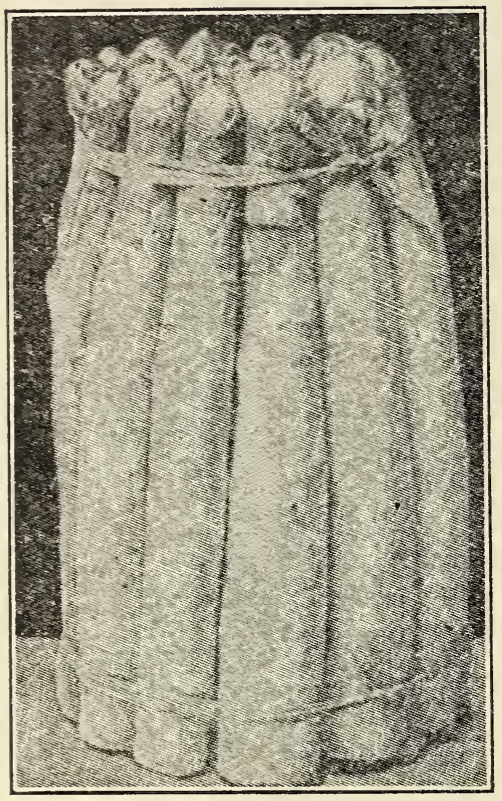

ASPARAGUS requires rich, well drained ground and plenty of potash which can be obtained by using \& high grade commercial fertilizer containing a high percentage of potash. Keep free of weeds, but do not dig the soil deeply enough to disturb the crowns or roots. In the late fall mow or cut the tops and burn them to destroy disease. Mulch with coarse manure and in the spring fork in the fall dressing with an ounce of salt to the square yard. Bordeaux will check rust and Arenate of Lead will destroy the Asparagus beetle Chlckens and ducks will devour the insects when tarned into the beds.

During the first season quick maturing, lowgrowing crops can be grown between the Asparagus rows. These may include bush beans, dwarf peas, early cabbage, lettuce and radishes but avoid tall-growing or long season crops.

ROOT CULTURE - The home gardener will find growing Asparagus from roots much easier. and cuttings may be had at least a year sooner. Prepare trenches $3 \mathrm{ft}$. apart and about 18 inches deep; fill with a liberal quantity of well rotted manure; after covering the manure with a few inches of dirt, set the plants $11 / \mathrm{ft}$. apart in each trench; 4 inch covering of good soil is then added. Do not exhaust the plants by cutting too late, especially the first bearing season; 100 roots plant a bed $20 \mathrm{ft}$. by $20 \mathrm{ft}$. Set roots either in spring or fall.

Fertilizers and Insecticides are listed on pages 49 and 50 .
CULTURE OF SEED-Sow the seed thinly is rows $1 \mathrm{ft}$, apart in April or May. 1 oz. produces 300 roots. To secure strong healthy plants, keep down all weeds and thin the poorest seedlings to 3 inches apart in each row. The roots may be dug either the first or second year in the fall after the plants die, and set either in the fall or spring, as described under "Root Culture."

MARY WASHINGTON-The Washington variety which was developed by the United States Do partment of Agriculture has proven as nearly rust proof as is possible to produce Asparagus. This in addition to the vigor of the plants, the thick shoots, the heavy yield and fine flavor make it an exceptionally valuable variety. The shoots are of rich, dark green color tinted somewhat darker at tips. The Mary Washington type is considered the best of the Washington variety.

Postpaid, pkt. $10 \mathrm{c}$; oz. $20 \mathrm{c} ; 1 / 4$ lb. $65 \mathrm{c} ; \mathrm{lb} . \$ 2.00$.

ASPARAGUS ROOTS-See page 22.

\section{ARTICHOKE SEED-Green Globe}

The Green Globe Artichoke is cultivated for its flower heads, which are cooked like Asparagus. Sow the seed in hot beds during February and transplant in May into rows 3 ft. apart and $2 \mathrm{ft}$. in the rows. The seeds may bo sown in the open during the month of April, and then the stand thinned. Artichoke requires a deep, rich, sandy loam with plenty of well rotted manure. When cold weather comes, protect the plants with a heavy covering of leaves or manure. If properly cared for the plants will bear for several years. Try a few in your garden. Although more or less of a novelty in this section, they are considered a great delicacy in the big cities and command a fancy price. An ounce plants $40 \mathrm{ft}$. of drill.

Postpaid, pkt. 10c; 1/2 oz. 45c.

\section{BRUSSELS SPROUTS}

The sprouts resemble miniature cabbage, growing, closely to stalk of the plant, being produced in abundance from the tip to the ground. Plant in May, transplanting $11 / 2$ feet apart, and cultivate like late cabbage. In the fall break off the leaves to give the heads more room. After hard frosts the flavor and delicacy are greatly improved.

The seed we offer is selected market garden stock raised and used by Long Island truckers. Plant seed $1 / 8$ inch deep. One ounce producen about 2000 plants.

Postpaid, pkt. $10 \mathrm{c}$; $1 / 2$ oz. $15 \mathrm{c}$ oz. $25 \mathrm{c}$.

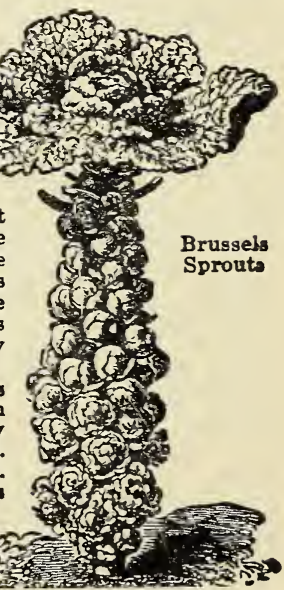




\section{DWARF OR BUSH BEANS}

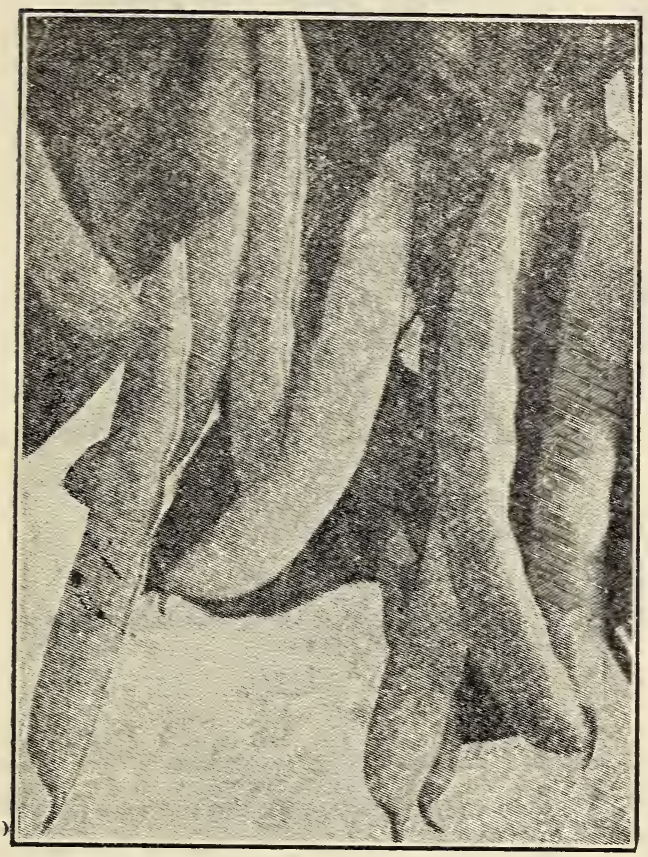

Improved Early Red Valentine Beans

CULTURE - Beans are very sensitive to both cold and wet. For the earliest crop, plant just as soon as the weather gets warm -in this section about the first of April. To have a succession, plant every two weeks throughout the summer until the middle of August. Make the rows 2 to 3 feet apart, drop the beans 3 inches apart and cover 11/3 to 2 inches deep. Give frequent but shallow cultivation up to blossoming time, not afterward, and never when the plants are wet. Plant in a light loamy soil that warms up quickly. Use plenty of fertilizer. Inoculate this seed with Stimugerm.

One pound will plant 60 feet of drill; 100 pounds to an acre in drills.

\section{Extra Early Red Valentine}

A very hardy, extra early and productire standard variety. Pods $41 / 2$ inches lons; cound, medium green, slightly stringy and of sood quality. The extreme hardiness of this bean accounts largely for its great popularity as it germinates in colder ground than do ther varieties. Recommended especially for first planting in the spring and last planting in August.

Postpaid, 1/2 lb. 25c; lb. 40c; 2 lbs. 70c; 5 lbs. $\$ 1.50$.

Not prepaid, lb. $30 \mathrm{c}$; 5 lbs. $\$ 1.25$.

\section{Giant Stringless Green Pod}

Somewhat similar to Burpee's Stringlese, but pod is a little longer, straighter and more slender, more depressed between beans and slightly lighter in color; early, hardy, entirels stringless and of highest quality.

Postpaid, $1 / 2$ lb. $25 \mathrm{c} ; \mathrm{lb} .45 \mathrm{c} ; 2$ lbs. $80 \mathrm{c}$; 5 lbs. $\$ 1.75$.

Not prepaid, lb. $35 \mathrm{c} ; 5$ lbs. $\$ 1.50$.

\section{Burpee's Stringless Green Pod}

This famous and popular bean is still unequaled as an early stringless green pod variety. It is stringless, ripens early, and remains crisp and tender long after maturing. The vines bear long, round, thick and very meaty pods, about 5 inches long, entirely free from strings. The attractive deep green color and unusual quality of these green pods has placed them in high favor. It has given entire satisfaction everywhere.

Postpaid, $1 / 2$ lb. 25c; lb. 45c; 2 lbs. $80 \mathrm{c}$; 5 lbs. \$1.75. Not Prepaid, lb. 35c; 5 lbs. $\$ 1.50$.

\section{Tennessee Green Pod}

This well known variety is almost as early s the Red Valentine. The productive plants bear handsome flat pods of dark green color almost stringless, and of exceptionally fine lavor and quality. Unlike most early beans, the quality remains good throughout its bearing season. The hardy and exceedIngly prolific tendencies of the Tennessee Green Pod accounts for its popularity 23 an early bunch bean.

Postpaid, $1 / 2$ lb. 25c; lb. $40 \mathrm{c}$; 2 lbs. $70 \mathrm{c}$ : 5 lbs. $\$ 1.50$. Not prepaid, 1b. $30 \mathrm{c} ; 5$ lbs. $\$ 1.25$.

For larger quantities than quoted in catalog please ask for prices stating quantity desired.

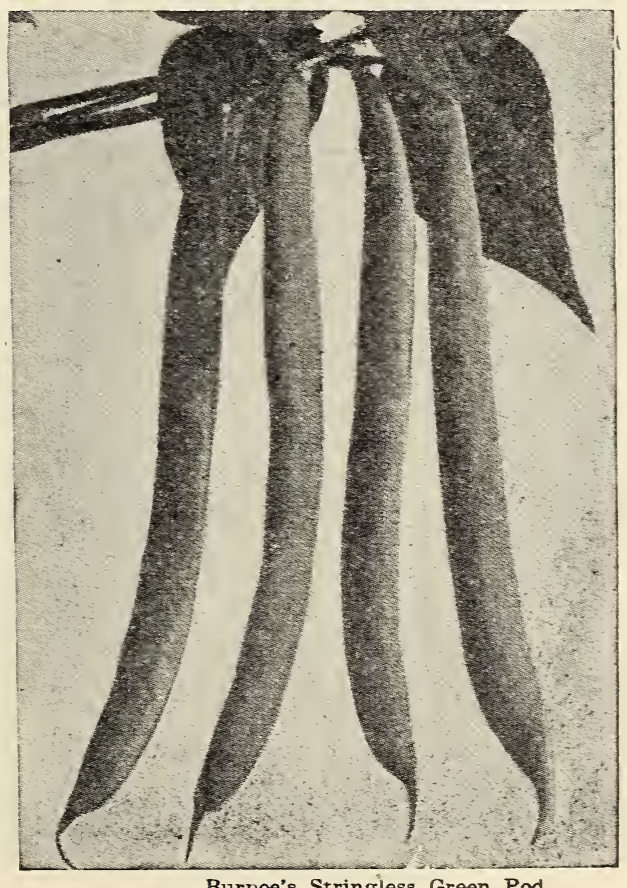

Burpee's Stringless Green Pod 


\section{Dwarf Or Bush Beans-Continued}

\section{Fordhook Favorite Bush}

A new, white seeded, high quality bean. Pods are $51 / 2$ to 6 inches long, straight, almost round, thick and meaty and showing marked depres: sions around the beans; strictly stringless and medium green in color; medium early and moderately productive.

Crop very short. Place order early for full

requirements. $1 / 2$ lb. 35c; lb. 60c; 2 lbs. $\$ 1.15$; 5 lbs. $\$ 2.50$. Not Prepaid, lb. $50 \mathrm{c} ; 5$ lbs. $\$ 2.25$.

\section{Bountiful or Early Six Weeks}

Best of the flat-podded stringless rarieties. Pods $61 / 2$ to 7 inches long, stout, flat and slightly curved, stringless, slightly fibrous, attractive and of fine quality: color, light green. Very early, vigorous, hardy, and productive. This variety may also be grown as a shell bean for winter. Postpaid, 1/2 lb. 25c; lb. $45 \mathrm{c} ; 2$ lbs. $80 \mathrm{c}$; 5 lbs. $\$ 1.75$. Not prepaid lb. $35 \mathrm{c} ; 5$ lbs. $\$ 1.50$.

\section{Rogers Stringless Refugee}

A very productive, hardy and vigorous late sort Ideal for canning and fine for the home garden as well. Fifteen inch dark strong vine, $51 / 2$ inch round stringless green pod ready for table use in approximately 84 days after planting. Postpaid, $1 / 2$ lb. $25 \mathrm{c} ; 1 \mathrm{lb} .45 \mathrm{c} ; 2$ lbs. $80 \mathrm{c} ; 5$ lbs. $\$ 1.75$. Not prepaid, lb. $35 \mathrm{c} ; 5$ lbs. $\$ 1.50$.

\section{Pencil Pod Black Wax}

This is the best strain of black wax beans. It is medium early, fairly hardy, productive and of the very highest quality. The plants are strong growing with roughened leaves. The pods are six inches long, round, slightly curved, fleshy and of a deep yellow color. They are tender, absolutely stringless and are produced through a long season.

Postpaid, 1/2 lb. 25c; lb. 40c; 2 lbs. 70c; 5 lbs. $\$ 1.50$. Not prepaid, lb. $30 \mathrm{c} ; 5$ lbs. $\$ 1.25$.

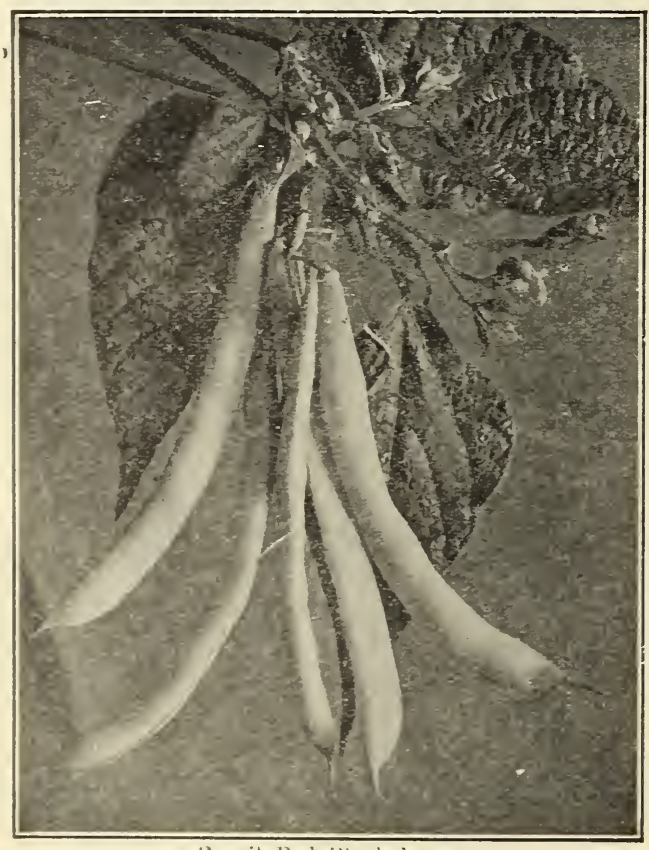

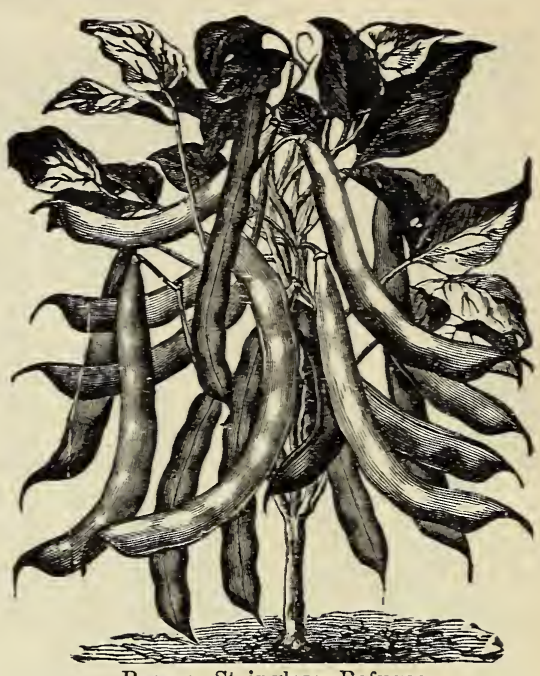

Rogers Stringless Refugee.

\section{DWARF SHELL BEANS}

CULTURE-Plant when ground is warm in spring and up to July 1st, in rows 2 feet apart and beans 3 inches apart, 11/2 inches deep. Keop well hoed and draw the earth up to the stemas but only when dry, as working when wet with rain or dew will cause rust and injure the crop. Sow Kidney Beans at rate of 75 lbs. to the acre; $1 \mathrm{lb}$. to $100 \mathrm{ft}$. of drill. Navy Beans $45 \mathrm{lbs}$. to the acre, $1 \mathrm{lb}$. to $150 \mathrm{ft}$. of drill.

RED KIDNEY - A well-known fleld var iety grown extensively for dry-shell pur poses. Of dwarf growth, very hardy and prolific. The pods are 51 , to 6 inches long, seeds are kidney-shaped of $\mathbf{a}$ light shade of red. It is one the largest of all baking beans.

Postpaid, 1/2 lb. 25c; lb. 35c; 2 lbs. $65 \mathrm{c}$ : Not prepaid $1 / 2$ lb. $15 \mathrm{c} ; 1 \mathrm{~b} .25 \mathrm{c} ; 5$ lbs. $\$ 1.15$.

WHITE NAVY-Pods are light green, straight, short, about three and threefourths inches, but usually containing six small oval white beans of superior quality for use as dry beans.

Postpaid, 1/ lb. 20c: lb. 35c; 2 lbs. 65e. Not prepaid, $1 \mathrm{~b} .25 \mathrm{c} ; 5$ lbs. $\$ 1.10$.

\section{BEAN BEETLE PEST}

To stop ravages of the Bean Beetle Pest the vines and foliage must be thoroughly sprayed with Magnesium Arsenate or dusted with Calcium Arsenate. These articles are described on page 50. Sprayers and Dusters are listed on pages 51 and 52 .

For larger quantities than quoted in catalog, please ask for prices, stating quantity desired. 


\section{POLE OR CORNFIELD BEANS}

CULTURE-Pole Beans are more sensitive to cold than the bush kinds, and should not be planted before the ground is warm-two or three weeks later than bush beans. Set poles 6 to 8 feet long, 3 to 4 feet apart, in 4 foot rows and plant 5 or 6 beans 2 inches deep around each pole. They may also be planted in the cornfield and allowed to run up the stalk. More troublesome to grow than bush beans, although they are of better quality and bear longer and more profusely. One ib. will plant 100 hills: $30 \mathrm{lbs}$, to the acre. Inoculate this seed with Stimugerm.

\section{White Creaseback}

Very hardy, very early and moderately productive. Pods 5 to 6 inches long, uniform, round and slender; slightly stringy, very fleshy, brittle and fine grained; fair quality; color light green. Beans small, oblong and white in color.

Postpaid, I/2 lb. $25 \mathrm{c}$; lb. $35 \mathrm{c}$; 2 lbs. $60 \mathrm{c}$ 5 lbs. $\$ 1.25$

Not prepaid, I/2 lb. $15 \mathrm{c}$; lb. $25 \mathrm{c} ; 5$ lbs. $\$ 1.00$.

\section{White Kentucky Wonder or Burger's Stringless Green Pod}

A very early, white seeded variety. Pods 6 to 7 inches long, round and nearly straight; very tender, fleshy and stringless; of high quality; color medium green.

Postpaid, I/2 lb. 25c; lb. 35̃c: 2 lbs. $60 \mathrm{c}$ lbs. $\$ 1.25$

Not prepaid, $1 / 2$ lb. $15 \mathrm{c}$; lb. $25 \mathrm{c}$; 5 lbs. $\$ 1.00$.

\section{Kentucky Wonder or Old Homestead}

The most popular, green-podded elimbing, or corn-hill bean; early and productive. Pods 8 to 9 inches long, very slender, decidedly eurved, slightly stringy, tender and good quality.

Postpaid, $1 / 2$ lb. 25c; lb. 35c; 2 lbs. $60 \mathrm{c}$; 5 lbs. \$1.25.

Not prepaid, I/2 lb. $15 \mathrm{c}$; lb. $25 \mathrm{c}$; $5 \mathrm{lbs} . \$ 1.00$.

\section{October or Horticultural, Wren's}

\section{Egg or Cranberry}

An old, well known, standard sort. Mid-season in maturity, hardy and productive. Pods 5 to 6 inches long, straight, flat, stringless and of good quality: color dark green, splashed with bright red. Especially adapted for mountainous districts, short seasons and cool locations.

Postpaid, $I / 2$ lb. $25 \mathrm{c}$; lb. 35c; 2 lbs. 60c; 5 lbs. $\$ 1,25$

Not prepaid, I' 2 lb. $15 \mathrm{c}$; lb. $25 \mathrm{c}$; 5 lbs. $\$ 1.00$.

\section{Striped Creaseback, or Scotia}

A very hardy and productive mid-season cornfeld bean. Pods 616 to 7 inches long, round, straight and creasebacked; slightly stringy, very fleshy, fine grained, attractive and good quality; pods light green.

Postpaid, I/2 lb, 25c; 1b. 35c; 2 lbs, 60c: 5 lbs. $\$ 1.25$

Not prepaid, I/2 lb. $15 \mathrm{c}$; lb. $25 \mathrm{c} ; 5$ lbs. $\$ 1.00$

\section{Lazy Wife}

A late, productive, standard sort. Pods 5 to 6 inches long, broad, straight and flat, stringless, very fleshy, brittle, fine grained, attractive and excellent quality. Color medium green; dry beans round and white. This is a superior variety for the home garden, also as a field bean among corn. Desirable either for cooking in the pod or shelled for winter.

Postpaid, $I_{2}$ lb. $25 \mathrm{c}$; lb. $35 \mathrm{c}$; 2 lbs. $60 \mathrm{c}$; 5 lbs. \$1.25.

Not prepaid, $1 / 2$ lb. $15 \mathrm{c} ; 1 \mathrm{~b} .25 \mathrm{c} ; 5$ lbs. $\$ 1.00$

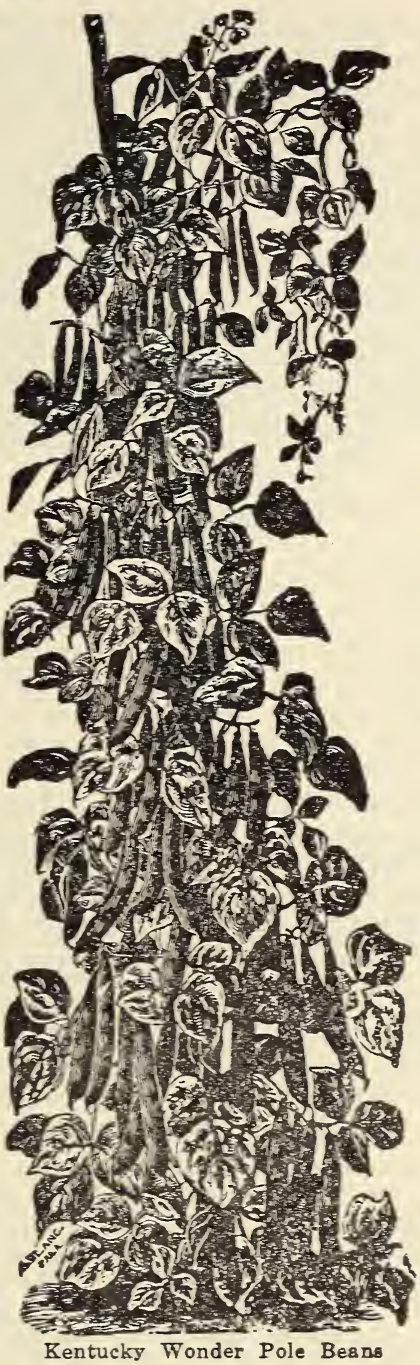

Red Speckled Cut-short

A well known, hardy, late and productive sort, Pods 31,6 to 4 inches long, stout, straight and flat, stringy, fine grained and fair quality; color light green.

Postnaid, I/2 lb. 25c; lb. 35c; 2 lbs. $60 \mathrm{c}$; lbs. $\$ 1.25$

Not prepaid, ${ }^{1 / 2}$ lb. $15 \mathrm{c}$; 1b. 25c; 5 lbs. $\$ 1.00$.

\section{Golden Cluster Wax}

An excellent pole wax-podded sort: early, rigorous, hardy and productive. Pods 616 to 7 inches long, extremely straight, broad and flat; very fleshy, stringy though fine grained, attractive and good quality; color light waxy-yellow. Beans, white, oval-shaped.

Postnaid. $\mathrm{I}_{2}$ lb. $25 \mathrm{c}$; lb. 35c; 2 lbs. $60 \mathrm{c}$ : 5 lbs. $\$ 1.25$.

Not prepaid, $1 / 2$ lb. $15 \mathrm{c}$; lb. $25 \mathrm{c}$; 5 lbs. $\$ 1.00$. 


\section{LIMA BEANS}

\section{Plant More Lima Beans For Boiling, Baking And Canning}

While Lima Beans are rapidly growing in popularity, this excellent table food is still not grown so extensively as it merits. Lima Beans have a rich and delicate flavor that is not found in other types of beans, and for this reason are unexcelled for baking, boiling, or canning. They are largely used as green beans cooked either alone or with sugar corn. As a dried bean they

keep as well as other types in any climate and are more nutritious food than most varieties.

Lima Beans should not be planted until the ground is warm and all danger of frost is over. The germination of practicaliy all Limas is not as high as ordinary beans, hence a liberal planting is necessary and cheaper in the end.

Inoculate this seed with Stimugerm.

\section{DWARF OR BUSH LIMAS}

CULTURE-Bush Limas are planted for early crop, since they come into bearing much sooner than pole varieties. The dwarf varieties are not as prolific as the Pole Lima Beans, but they produce a good crop of equal quality and are not so difficult to grow; always plant the eyes down, dropping 3 beans 15 inches apart in rows 3 feet apart. The bean should be covered from $11 / 2$ to 2 inches deep.

\section{Henderson's Bush Lima}

A dwarf form of the Small White Lims, raluable on that account, and extreme earliness, hardiness and productiveness. Continuing to grow and set pods until frost. Pods are medium dark green, short, about two and three-fourths inches, flat and contain two to four beans which are of excellent quality either green-shelled or dry. Seed mall, flat and white with slight tinge of yellow. One pound will plant 100 hills; 30 lbs. to the aere.

Postpaid, $1 / 2$ lb. $25 \mathrm{c}$; lb. $35 \mathrm{c}$; 2 lbs. $65 \mathrm{c}$.

Not prepaid, $1 / 2$ lb. $15 \mathrm{c}$; $1 \mathrm{~b}$. $25 \mathrm{c} ; 5$ lbs. $\$ 1.15$.

\section{Burpee's Improved Bush Lima}

This is a little the earliest maturing of the large veeded limas. The plants are vigorous and productive. The pods are medium green, very large, about five inches long, thick, and usually contain four beans, which are unusually thick, of largest vise and excellent quality, and usually show a creenish white tinge which is generally considared an indication of superior quality. One of the best and most extensively used bush limas for the market as well as home garden. One pound will plant 60 hills; 60 lbs. to the acre.

Postpaid, $1 / 2$ lb. $30 \mathrm{c}$; lb. $45 \mathrm{c} ; 2$ lbs. $80 \mathrm{c}$.

Not prepaid, $1 / 2$ lb. $20 \mathrm{c}$; lb. $35 \mathrm{c} ; 5$ lbs. $\$ 1.45$.

\section{Fordhook Bush Lima}

A most excellent variety and exceedingly popular with market gardeners. Pods about 5 inches long, containing 4 to 5 large oval-shaped, very thick white beans of the so-called Potato Lima trpe. The plants are vigorous and erect, bearing well above the ground. The pods, which are produced in large clusters, are medium green in color. The beans are of exceptionally fine quality and are produced so abundantly as to make this one of the best paying crops that can be ralsed. One pound will plant 60 hills; 60 lbs. to the acre.

Postpaid, 1/2 lb. $30 \mathrm{c}$; lb. $50 \mathrm{c}$; 2 lbs. $90 \mathrm{c}$.

Not prepaid, $1 / 2$ lb. $20 \mathrm{c}$; lb. $40 \mathrm{c} ; 5$ lbs. $\$ 1.75$.

\section{TALL OR POLE LIMAS}

CULTURE-Plant 3 or 4 beans to the hill 3 ft. apart in 3 or $4 \mathrm{ft}$. rows. Cover $11 / 2$ to $2 \mathrm{ln}$ ches deep with eyes down. It is necessary to provide poles 6 to $8 \mathrm{ft}$. long for each hill. The beans will make a very rapid growth if a small shovel full of well rotted cow manure is added to each hill when the poles are set. All Pole Limas are exceedingly prolific and are preferred by truck gardeners.

\section{Carolina Seiva or Small Seeded Pole Lima}

"The Butter Bean of the South." These grow quickly, mature early, and are extremely prolife. The beans are small and white, on the order of Henderson's Bush Lima. They make dried bean of superior merit. One pound will plant 100 hills ; $30 \mathrm{lbs}$. to the acre.

Postpaid, 1/2 lb. 25c; lb. 35c; 2 lbs. 65c.

Not prepaid, $1 / 2$ lb. $15 \mathrm{c} ; \mathrm{lb} .25 \mathrm{c} ; 5$ lbs. $\$ 1.15$.

\section{King of the Garden Lima}

The vines of this standard pole lima are very vigorous and productive. The pods are medium dark green, very large, five to six inehes long. broad, flat, filled with four or five very large white beans of finest quality. On account of its large pods it is a favorite with market gardeners. It will come into bearing earlier and make larger pods if not more than two vines are left to grow on a pole. Seed very large, ovoid, flat, white with slight greenish tinge. One pound will plant 60 hills ; $60 \mathrm{lbs}$. to the acre.

Postpaid, I/2 lb., 25c; lb., 40c; 2 lbs., 70c. Not prepaid, lb., $30 \mathrm{c} ; 5$ lbs., $\$ 1.30$.

\section{Carpinteria Pole Lima}

A most desirable pole lima for the home and market garden. The vines are strong, growing and vigorous, producing an abundance of fine, large, medium green pods, five to six inches long, usually closely filled with four beans of largest size, much thicker than the average pole lima The color is distinctive in having a decided sreonish tint, an indication of very finest quality. When cooked, the beans are very thin skinned, extremely tender and of finest flavor. Seed very large, exceptionally thick, retaining the distinotly green tinge. One pound will plant 60 hills: 60 lbs. to the acre. Postpaid, 1/ 1b., 25c; lb., 40c: 2 lbs., 70c. Not prepaid. lb.. 30 c: 5 lbs., $\$ 1.30$.

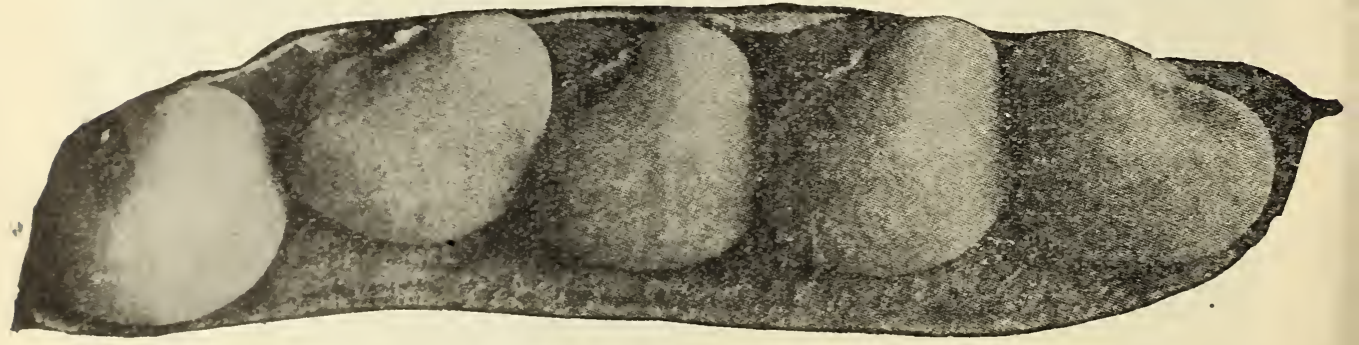




\section{GARDEN OR TABLE BEETS}

CULTURE-Beets thrive best in rather light, mellow and deep-worked soil which has been thoroughly enriched with well-rotted manure or fertilizer, which should be well mixed with soil. Sow in drills about 18 inches apart, covering about one inch deep and thin out the plants to 4 inches apart in the drills. For a small garden the drills need not be more than 12 to 15 inches apart. One ounce will sow $50 \mathrm{ft}$. of drill, 6 to $8 \mathrm{lbs}$. to the acre.

\section{Extra Early Egyptian}

The best variety for forcing; also excellent for first early crop outdoors, being very early. Small tops, roots distinctly flat but moderately thick, very dark red; flesh dark purple red, zoned a lighter shade. Much used for bunching.

Postpaid, pkt., $5 \mathrm{c}$; oz., 10c ; $1 / 4$ lb., $30 \mathrm{c}$; lb., $90 \mathrm{c}$.

\section{Crosby's Egyptian}

The largest of the very early sorts. It is very quick to attain size. The shape is a little flat but very uniform. The tops are small, the color is bright red, flesh a trifle lighter in color and lightly zoned; very sweet and tender. An improvement on other Egyptian sorts, being almost as early and of more desirable shape, color and quality. Excellent for early outdoor planting and bunching for sale or home use.

Postpaid, pkt. $5 \mathrm{c}$; oz. $10 \mathrm{c} ; 1 / 1 / 1 \mathrm{lb} .30 \mathrm{c}$; lb. $90 \mathrm{c}$.

\section{Early Eclipse}

An early beet expecially desirable for the home garden and used for bunching. The tops are small with medium sized, round, bright red roots; flesh bright red, zoned pinkish white. A very tender, crisp and sweet beet, especially when young, but retains these good qualities as it gets older.

Postpaid, pkt., 5c ; oz., 10c; 1/4 lb., 30c; lb., 90c.

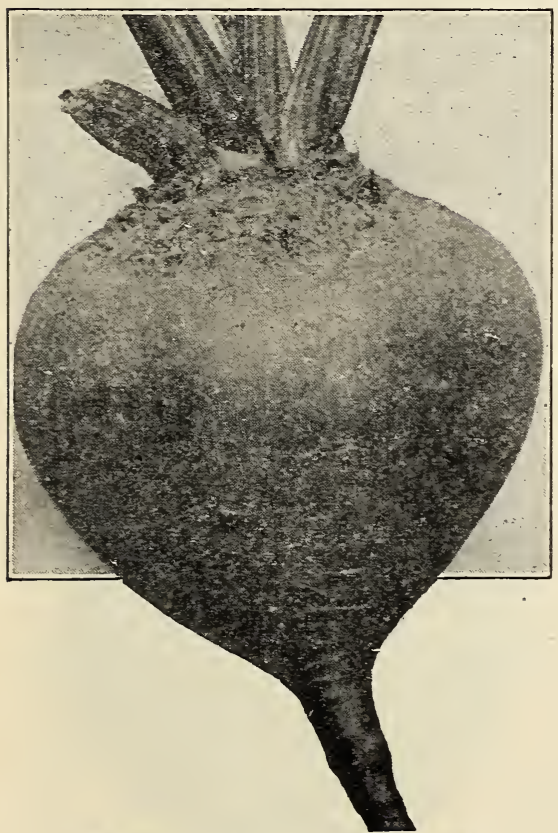

Edmand's Early Blood Turnip Beet

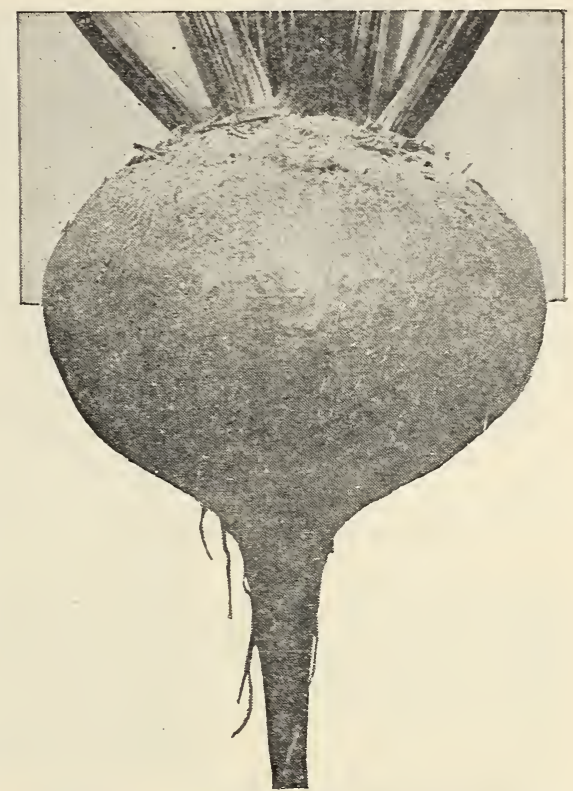

Detroit Dark Red

Edmand's Early Blood Turnip Beet

A desirable second early market sort and suitable as well for the home garden. Short tops, roots nearly round, dark red; flesh purplish red with light zoning. Although classed as a second early variety, it is grown largely as a main crop beet and as it is a splendid keeper, is well adapted to this purpose.

Postpaid, pkt., 5c ; oz., 10c ; $1 / 4$ lb., 30c ; lb., 90c.

Detroit Dark Red or Red Ball

One of the very best sorts for home or market garden and for canning purposes. Roots uniformly smooth of medium size, and globe shaped; skin dark red, flesh solid vermillion red, seldom showing any white zones. Quality is of the very best, sweet, tender and never stringy. A good variety for early and late planting. The tops being small and upright growing, permit close planting. This is our biggest seller and from all reports, is the beet best adapted to this section.

Postpaid, pkt., 5c; oz., 10c ; $1 / 4$ lb., $30 \mathrm{c}$; lb., $90 \mathrm{c}$.

\section{SWISS CHARD-TURNIP BEETS}

Swiss Chard is grown much in the same way as beets. The seed should be sown during April or May, in drills 16 to 20 inches apart, and the seedlings thinned out to stand from one to two feet apart in the row. Swiss Chard grows easily in any well-drained, fertile soil. The plants are quite hardy, and will yield throughout the summer and fall until severe frosts touch the foliage. The leaves are usually boiled, similarly to spinach, which they resemble in flavor. The large white ribs are creamed like asparagus. One ounce for 100 feet of drill; 4 lbs. per acre in drills.

LUCULLUS-An enormous yielding, strons growing variety with extra large leaves whieh are thick, heavily crumbled and curled.

Postpaid, pkt. $5 \mathrm{c}$; oz. $10 \mathrm{c}$; $1 / 4$ lb. $30 \mathrm{c}$; lb. \$1.0.

\section{For Stock Beets See Page 45}




\section{LONG ISLAND GROWN CABBAGE SEED}

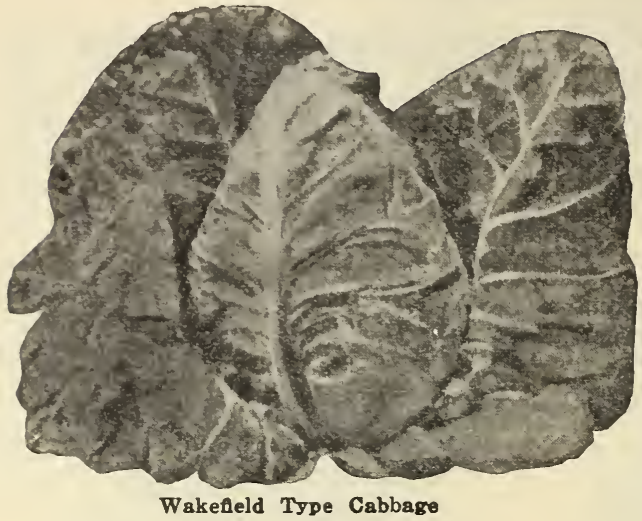

Culture-For plants of the earliest sorts, sow seed in January or February under glass, and put out in flats or frames about 2 inches apart each way. Transplant to open ground as soon in spring as the land can be properly prepared. A rich, warm, fibrous loam is best. Set the early plants in rows about 18 inches apart, and rows at least 2 feet apart. Give thorough cultivation and irrigate in dry weather if practicable A little nitrate of soda applied around the plant is of great benefit. A fertilizer with a high percentage of potash will also do much good. For late cabbage plants, sow seed in drills in open ground during April and May, and transplant in June and July about 2 feet apart in $21 / 2$ foot rows. Dusting with tobacco dust, slug shot, ete., are good and safe remedies for some of the insect pests attacking plants of the cabbage family. Sow one ounce for 2,000 plants; 6 to 8 ounces for one acre. Cover $1 / 2$ in. deep.

\section{Early Jersey Wakefield}

The most popular extra early cabbage. Plants are compact, erect, with few outer leaves and withstand cold and unfavorable weather well as they are very hardy. Heads are medium size, cone shaped and solid. This variety has been for a long time the market gardeners favorite for a first early cabbage.

Postpaid, pkt. $5 \mathrm{c}$; oz. $25 \mathrm{c} ; 1 / 4$ lb. $75 \mathrm{c} ; \mathrm{lb} . \$ 2.50$.

\section{Charleston or Large Wakefield}

This is a selection from the best Early Jersey Wakefield type with the same characteristics, but is much larger and although it matures about a week later, is popular with many growers on account of its large size.

Postpaid, pkt. $5 \mathrm{c}$; oz. $25 \mathrm{c} ; 1 / 4$ lb. $75 \mathrm{c} ; 1 \mathrm{lb} . \$ 2.50$.

\section{Copenhagen Market}

Very fine and nearly as early as Jersey Wakefeld Plants are vigorous but compact bearing on short stems heads that are large, round and solid with few outer leaves, light green in color and of upright growth. An excellent variety for either home or market garden.

Postpaid, pkt. $5 \mathrm{c}$; oz. $30 \mathrm{c} ; 1 / 4$ lb. $90 \mathrm{c} ; \mathrm{lb} . \$ 2.75$.

\section{Henderson's Early Summer}

A splendid second early sort, being ten days later than Jersey Wakefield. Heads are medium in size, round, somewhat flattened, compact and solid; outer leaves are spreading and light green in color. A sure and reliable header.

Postnaid, pkt. $5 \mathrm{c}$; oz. $25 \mathrm{c} ; 1 / 4$ lb. $75 \mathrm{c}$; $1 \mathrm{~b} . \$ 2.50$.

\section{Early Flat Dutch}

A standard second early short stemmed variety. Heads are similar to Late Flat Dutch, except that they are somewhat smaller and mature earlier. A ure header and thoroughly satisfactory cabbage in every way.

Postpaid, pkt. $5 \mathrm{c}$; oz. $25 \mathrm{c} ; 1 / 4$ lb. $75 \mathrm{c} ; \mathrm{lb} . \$ 2.50$.

\section{Early Drumhead}

Produces large, firm, broad, flat heads, fine grained and sweet. Heads weighing from 15 to 25 pounds. It is ready for marketing two or three weeks earlier than the Late Drumhead.

Postpaid, pkt. $5 \mathrm{c} ;$ oz. $25 \mathrm{c} ; 1 / 4$ lb. $75 \mathrm{c} ; \mathrm{lb} . \$ 2.5 \mathrm{C}$

\section{Late Flat Dutch}

A very popular and highly esteemed variety, extensively cultivated for market and family use. Heads are large, round, flattened and very firm: has a short stem and is very hardy. A fine main crop cabbage.

Postpaid, pkt. $5 \mathrm{c}$; oz. $25 \mathrm{c} ; 1 / 4$ lb. $75 \mathrm{c} ; \mathrm{lb} . \$ 2.50$.

\section{Large Late Drumhead}

This is a very hardy and desirable fall and winter cabbage. Heads large, flat and solid. A good keeper and shipper.

Postpaid, pkt. $5 \mathrm{c}$; oz. $25 \mathrm{c} ; 1 / 4$ lb. $75 \mathrm{c} ; \mathrm{lb} . \$ 2.50$.

\section{Danish Ball Head}

One of the best winter sorts and one of the most hardy. The strong growth of this variety enables it to withstand dry weather well, and its good keeping quality makes it a most valuable cabbage for winter storing. Heads which are borne on short stems are medium size, round and very solid. A handsome and valuable type that should be more extensively grown in this section.

Postpaid, pkt. $5 \mathrm{c}$; oz. $30 \mathrm{c} ; 1 / 4$ lb. $90 \mathrm{c} ; \mathrm{lb}$. $\$ 2.75$.

CABBAGE PLANTS-See page 22.

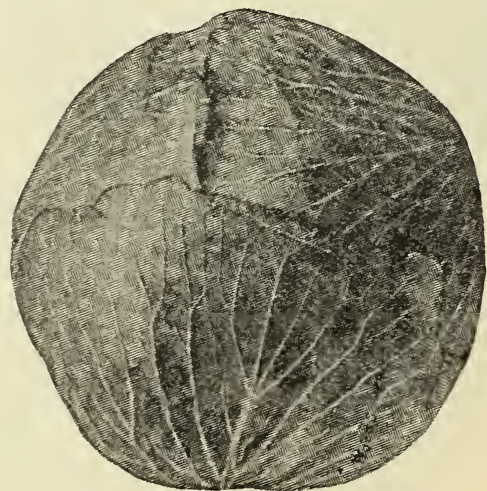

Danish Ball Head. 


\section{CARROTS}

CULTURE - Sow in a light, rich, deeplyworked soil as early as you can work the ground, in drills 12 inches apart and $1 / 2$ inch deep; press the soil firmly after planting and when well up thin out to 3 or 4 inches apart in the row. For field culture, make the drills 18 to 24 inches apart; later sowings should be made in July and August for a late crop to store for winter. In dry weather soak the seeds before sowing. To store for winter, pack in dry earth or sand in the cellar or put them outside on a well-drained situation, covering with a few inches of straw and 6 to 8 inches of earth to protect from frost. One oz. will sow $100 \mathrm{ft}$. of drill; 3 to $4 \mathrm{lbs}$. to the acre.

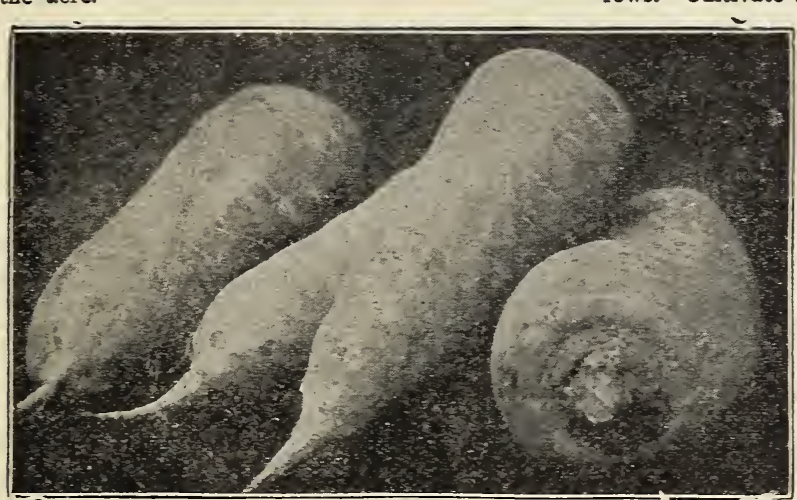

CAULIFLOWER

CULTURE-Cauliflower requires much the rame treatment and cultivation as cabbage, but is not as bardy in resistance to either hot or cold or dry weather. The plants should have an abun. dance of water in the summer and protection during cold weather. Early planting is essential in this section. Plant in hot beds in February, March and early April, cover seed with 1/2 in. fine soil firmly pressed down. Transplanting should be done in moist weather. Be sure to transplant to a rich, well fertilized moist soil, at least as rich as the seed bed. 14 oz. produces about 500 plants, 3 to 4 ounces make enough to plant an acre. Set plants 15 to 18 inches apart in 3 foot rows. Cultivate frequently. When the heads are about two inches across, tie up the outer leaves to blanch the heads and protect them from the sun and weather; this prevents them becoming bitter and discolored. Cut when head is hard and compact.

EARLY SNOWBALL - Thi variety is not only the earliest to head but a remarkably sure header, making large, solid, perfect, pure white heads of the finest quality.

Plant compact in growth with ew short, outside leaves. Suitable alike for home or market garden and adapted for foreing as well es growing out of doors.

For several years we have been importing Early Snowball Cauliflower seed direct from Europe. Truckers have had splendid success with their crops from this seed. We believe that Cauliflower can be made
Danver's Half Long Carrote

OXHEART-Very early and one of the heaviest rielders and the best for stiff and heary soils where the longer varieties might fail. Fully the top, and from 3 to 4 inches in length. The lesh is bright orange in color; free from hard core or fiber, and are sweet and tender. Exceptonally fine for the home garden, and solls quiekly on the market, due to its fine appearance and superb quality. They are sweetest when still small.

Postpaid, pkt. $5 \mathrm{c}$; oz. $10 \mathrm{c}$; $1 / 4$ lb. $30 \mathrm{c} ; \mathrm{lb} . \$ 1.00$.

CHANTENAY - A most excellent, medium early, half long variety. It is one of the best in quality for the market and home garden, while its grent productiveness and the ease with which it can bo harvested make it desirable as a field sort. The tops are medium sized with small neck. The mature roots are thick, five and one-half to six inches in length, uniformly half long or stump rooted but tapering slightly, smooth, deep orange red in color. The flesh is very crisp and tender. Although a medium early sort the roots are suitable for use nearly as early as any. The variety is extensively used for bunching

Postpaid, pkt. 5c; oz. $10 \mathrm{c} ; 1 / 4$ lb. $30 \mathrm{c} ; \mathrm{lb} . \$ 1.00$.

DANVER'S HALF LONG-A half long orange earrot, grown largely on account of its great productiveness and adaptability to all classes of soil. It is a desirable second early and main crop carrot for the home garden and is also suitable for feld culture. The tops are of medium size. The mature roots are of medium length, six to eight inches long, tapering uniformly to a blunt point. The flesh is deep orange, tender and of good qual. th. Although the roots of this variety at maturity are comparatively short, they often produce a large a bulk as the longer field sorts and are more easilly harvested.

Postpaid, pkt. 5c; oz. 10c; 1//z Ib. $30 \mathrm{c}$; lb. $\$ 1.00$. srown roots measure $2 \frac{1}{2}$ inches in diameter at one of the best paying crops for this section, as it always commands a good price. It requires pays the effort expended.

Postpaid, pkt., 15c; 1/4 oz., 55c; 1/2 oz., \$1.00; oz., $\$ 1.75 ; 1 / 41$ lb., $\$ 6.00$.

\section{CAULIFLOWER PLANTS-See page 22.}

\section{COLLARDS}

Collards are cultivated and grown much the same as cabbage. They are strictly a Southern vegetable and are the old time winter greens, being improved by the touch of frost.

Sow the seed thickly in drills, in rich ground, transplanting when about four inches high; or sow in drills where the plants are to remain and when well started, thin to two or three feet apart in the row. In this section seed may be sown from March to May, but is usually sown from July to September. Sow 1 oz. of seed to $100 \mathrm{ft}$ of row, covering $1 / 2$ in. deep.

TRUE GEORGIA OR SOUTHERN-This is the white or green stemmed variety, growing two to three feet high and forming a large, loose open head or cluster of leaves with a rather long stem A frost, if not too severe, will improve rather than injure the quality of the leaves.

Postpaid, pkt. $5 \mathrm{c}$; oz. $10 \mathrm{c}$; $1 / 4 \mathrm{lb} .25 \mathrm{c}$; lb. $75 \mathrm{c}$.

NORTH CAROLINA SHORT STEM-A decided improvement, and has proved very popular wherever grown. Has short stem, large spreading leaves, very hardy, withstanding drought in summer and cold in winter. Its flavor and cooking qualities are the very best.

Postpaid, pkt. $5 \mathrm{c}$; oz. $10 \mathrm{c} ; 1 / 4 \mathrm{lb} .25 \mathrm{c}$; lb. $75 \mathrm{c}$. 


\section{GARDEN AND SUGAR CORN}

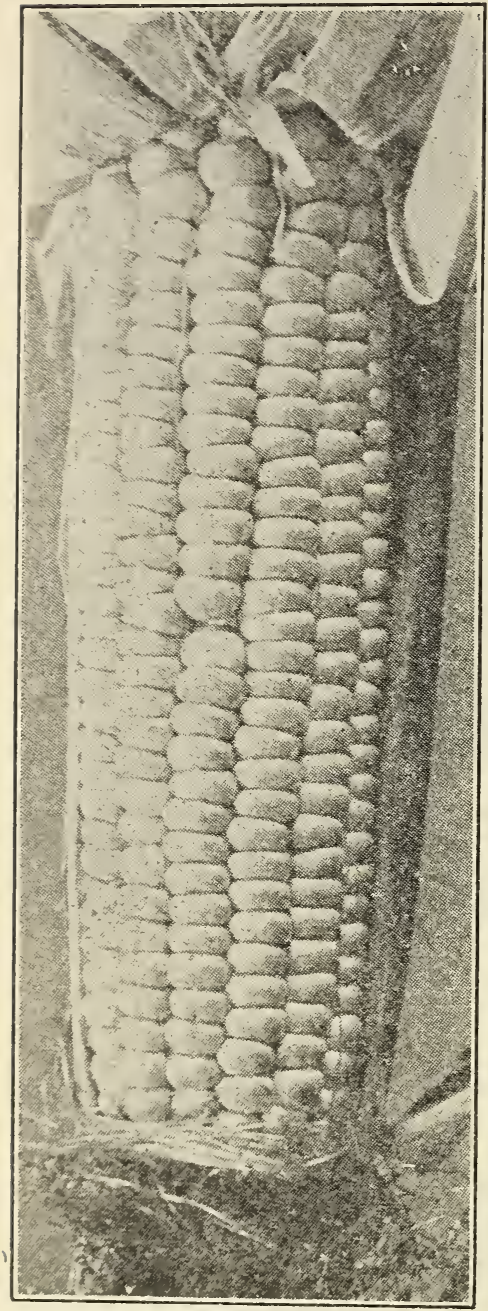

Golden Bantam Sugar Corn

CULTURE-Corn thrives best in a rich, warm wellmanured soil, that has been deeply and thoroughly worked before planting. To secure bumper crops use commereial fertilizer in addition to stable manure. Plant the early varieties the last of March or early in April; 8 weet corn are tender and should not be planted till the ground thoroughly warm, otherwise they are liable to rot.

Plant at intervals of about two weeks apart, so as to have a succession of roasting ears throughout the season This method is also a protection in case the first plantings are lost. Continue plantings through July and into August, if season is favorable, for late roasting ears.

If planted in rows, make the rows three to four feet apart and place the seed twelve to sixteen inches apart in the row, covering one inch deep with fine soil firmly pressed down.

If planted in hills, make the hills for the early varietic. three feet apart each way and plant four to six kernels to the hill. For the later sorts the hills should be three and one-half to four feet apart each way. Hoe frequently and when six inches high thin so as to leave three or four plants in the hill. Give frequent and thorough but shallow cultivation until the tassels appear. One pound will plant 100 hills; 10 to 12 lbs. plants an acre.

ADAMS EXTRA EARLY-Not a sugar corn, but a good small roasting ear largely grown for very early use, being hardy, standing early planting and the thick, hard husks not only protect the ear from cold, but prevent the entrance of the corn worm. For extra early roasting ears this is the variety to plant, but will not produce a big, showy ear. Postpaid, 16 lb., 15c; lb., 25c; 2 lbs., 40c; 5 lbs., 90c. Not prepaid, lb., 20c; 5 lbs., $70 \mathrm{c}$.

IMPROVED LARGE ADAMS-This is also a hardy corn about two weeks later than Adams Extra Early, but mueh bigger and better. The stout stalks grow to $7 \mathrm{ft}$. in height, bearing one or two large or medium sized ears, which are well filled with fine white grain that is of excellent qualits if pulled at the proper stage. Not a true sugar corn, but an excellent roasting ear.

Postpaid, 1/ lb., 15c; lb., 25c; 2 lbs., 40c; 5 lbs., 90c.

Not prepaid, lb., 20c; 5 lbs., 70c.

TRUCKER'S FAVORITE-For a second early corn to follow Adams Early, or for late planting to mature early, this is a good sort. It is a white corn, with good depth of grain tender and sweet, and makes most desirable size for roasting ears. It makes an excellent field corn to follow potatoes and other early crops and in addition to being an excellent roasting ear, makes fine meal. Not a true sugar corn, but one of the favorite roasting ears.

Postpaid, 1/2 lb. $15 \mathrm{c} ;$ lb. $25 \mathrm{c} ; 2$ lbs. $40 \mathrm{c} ; 5$ lbs. $90 \mathrm{c}$.

Not prepaid, lb., 20c; 5 lbs., $70 \mathrm{c}$.

GOLDEN BANTAM-This is the earliest of the true sweet corns. For sweetness and richness of flavor it has no equal. It is hardy, a vigorous grower, an early maturing variety of very dwarf growth and can, therefore, be planted closer than other sorts and through a longer range of season. The cob is small but fills out nicely with large, deep, cream-colored kernels, which turn to yellow when ready for the table. Each stalk bears two or three well flled ears, sis to seven inches in length and eight rowed.

Postpaid, $1 / 3$ lb., 20c ; lb., 35c; 2 lbs., 60c ; 5 lbs., $\$ 1.25$. Not prepaid, 1\% lb., 15c; lb., 25c; ह lbs., $\$ 1.00$.

HOWLING MOB-A big eared medium early corn with the sweet flavor of the late varieties Stalks usually bear two ears 7 to 8 inches lons with 12 to 14 rows of pearly white grains. The shock extends well over the tip and protects it from the worm so destructive to early sweet corn. Postpaid, $z / 2$ lb., 20c : lb., 35c; 2 lbs., 60c: 5 lbs., $\$ 1.25$. Not prepaid, $1 / 2$ lb., $15 \mathrm{c}$; lb., $25 \mathrm{c}$; 5 lbs., $\$ 1.00$.

COUNTRY GENTLEMAN-The leading midseason variety and a very popular and satisfactory corn for this section. The ears are 7 to 8 inches long, cob small, white and densely covered with long, slender, white grains without row formation. The stalks grow $6 \frac{1}{2}$ to 7 feet high, bearing two or three ears. A good yielder, and keeps in good condition a long time.

Postpaid, 1/2 lb. 20c; lb. 35c; 2 lbs. 60c; 5 lbs. $\$ 1.25$.

Not prepaid, 1/2 lb. $15 \mathrm{c}$; lb. $25 \mathrm{c}$; 5 lbs. $\$ 1.00$.
STOWELL'S EVERGREEN-The standard main crop sweet corn, more extensively planted than any other variety, being the general favorite for the home garden and market for late use. If planted at the same time with earliest kinds, it will keep the table supplied until October. The stalks grow about 7 1-2 feet high, bearing an sbundance of ears 8 to 9 inches long, sixteen to eighteen rowed with very deep, sweet white grains of delicious flavor, remaining a long time in $g 00 d$ cooking condition.

Postpaid, 1/2 lb. 20c; lb. 35c; 2 lbs. 60c; 5 lbs. $\$ 1.25$.

Not prepaid, 1/2 lb. $15 \mathrm{c} ; \mathrm{lb} .25 \mathrm{c} ; 5$ lbs. $\$ 1.00$.

For Larger quantities than quoted in cata log please ask for prices stating quantity desired. 


\section{CUCUMBER SEED}

CULTURE-In order to obtain the largest yield of cucumbers, the soil should be well enriched with well rotted manure or sheep fertilizer, but an abundance of good fruit can be raised on any rich garden oil. Plant the seed not over an inch deep in hills four to six feet apart each way, dropping fliteen to twenty seeds in a hill. After the plants begin to crowd and danger from the striped beetle is prettry well over, thin to three plants to the hill. Give frequent but shallow cultivation until the plants make runners so long that this is impracticable.

In this section it is best to make two sowings; one in the early spring and the second late in June and early in July. One ounce is gufficient for 50 hilis; 2 lbs. to the acre. Spray with Dowco or a mix ture of Arsenate of Lead and Bordeaux when plants are young, in late afternoon or early evening. A light sprinkling of tobacco dust also does a great deal of good. Try planting a radish seed in every hill, as it helps to keep the bugs awsy.

Pick the fruit as soon as it is large enough and before it begins to ripen, otherwise the vines will stop bearing.

WHITE SPINE, MMPROVED EARLY - The earliest and best known of the White Spines; a short, square ended, rather three cornered type, 7 in. long, very oroductive, fine for slicing or pickles; medium green color.

Postpaid, pkt. 5c; oz. 15c; 1/t lb. 40c; lb. \$1.25.

EARLY CLUSTER-Very early and prolific Fruit which is borne in clusters in the center of the plant, is light green in color, chunky in shape and about 5 inches long.

Postpaid, pkt. 5c; oz. $15 \mathrm{c} ; 1 / 4$ lb. $40 \mathrm{c} ; \mathrm{lb} . \$ 1.25$.

CHICAGO PICKLING-A small, crisp, dark green early, prolific sort more largely used for pickling than any other kind. 6 inches long. Postpaid, pkt. $5 \mathrm{c}$; oz. $15 \mathrm{c}$; $1 / 4$ lb. $40 \mathrm{c}$; lb. $\$ 1.25$.

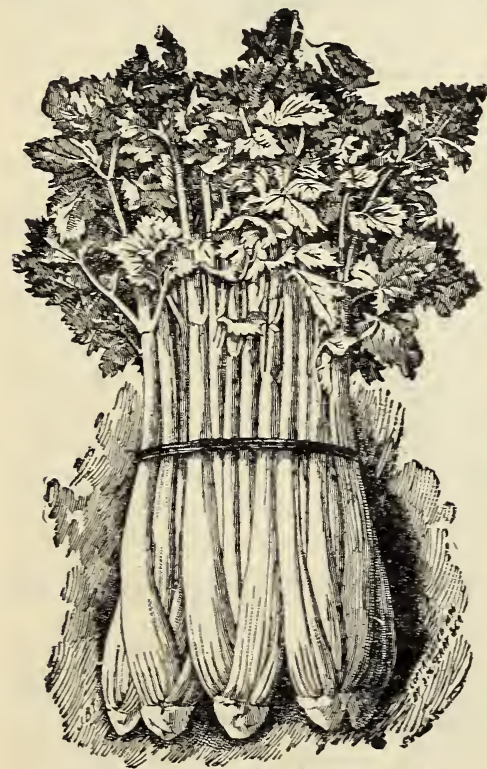

Golden Self Blanching Celery
DAVIS PERFECT-An extra long, dark green mid-season type of White Spine; retsins its color and good qualities long after being picked; fruit is 11 inches long, smooth and tapering at botb ends, flesh crisp, solid, with few seeds.

Postpaid, pkt. $5 \mathrm{c}$; oz, $15 \mathrm{c} ; 1 / 4 \mathrm{lb}, 40 \mathrm{c} ; \mathrm{lb}, \$ 1.25$. LONG GREEN, IMPROVED-A standard late, well known table sort. Twelve to fourteen inches long, slender, more or less warted, tapering towards the stem end, color dark green, flesh whito and firm.

Postpaid, pkt. 5c; oz. $15 \mathrm{c} ; 1 / 4$ lb. $40 \mathrm{c} ; \mathrm{lb} . \$ 1.25$.

\section{CELERY SEED}

CULTURE-Sow seed in February, March or April, in rows, and if dry enough, press the soil firmly with a roller or the back of a spade. Soak seed for 24 hours before planting; cover very lightly and keep constantly moist. When 4 inches high, cut off tops to make the plants grow stockr. Transplant from June to October in rows 3 feet apart, 6 inches apart in row. When the plants are nearly full grown they should be "handled," which is done by gathering the leaves together while the earth is drawn about the plant to one-third its height, taking care that none of it falls between the leaves. Repeat the process every few days until only the tops of the leaves are visible. One oz., sows about 100 feet, and produces about 2,000 plants.

IMPROVED WHITE PLUME-The earliest and most easily blanched as well as the most satisfactory celery for spring sowing in this section. Foliage is an attractive light green. Stalks are pure white, crisp and of a delicious nutty flavor. It is a popular variety for early market and a great addition to the home garden.

Postpaid, pkt. $5 \mathrm{c}$; $1 / 2$ oz. $15 \mathrm{c}$; oz. $25 \mathrm{c} ; 1 / 41 \mathrm{~b} .75 \mathrm{c}$.

GOLDEN SELF-BLANCHING-A golden jellow color; ribs are brittle, and of a delicious flavor. This is the earltest maturing sort. Stalks are heavy, perfectly solid, about 20 inches high; easily blanched.

Postpaid, pkt. 5c; $1 / 2$ oz. $35 \mathrm{c}$; oz. $60 \mathrm{c} ; 1 / 4 \mathrm{lb}$. $\$ 2.25$.

WINTER QUEEN-This is the finest winter variety. It is of dwarf growth; foliage is a rich green color. The plants make large bunches of extra heavy stalks with very large hearts. It is easily blanched and is a splendid variety for either home garden or truck farmers.

Postpaid, pkt. $5 \mathrm{c} ; 1 / 2$ oz. $15 \mathrm{c}$; oz. $25 \mathrm{c} ; 1 / 1 / 1 \mathrm{lb} .75 \mathrm{c}$.

CELERY PLANTS-See page 22. 


\section{EGG PLANT}

CULTURE-Seed germinates slowly and should be started in hotbed, covering $1 / 4 \mathrm{in}$. deep, for in this, as in all semi-tropical plants, it is important to secure a rapid and continuous growth from the first, the plants never recovering from a check received when young. When plants have two rough leaves transplant three or four inches apart. When the ground is warm and all danger not only from frosts, but from cold nights is past, harden off by gradual exposure to the sun and air and decreasing the supply of water, then carefully transplant to open ground, setting two and onehalf feet apart in a deep, rich loamy soil. In very cool and wet summers egg plants frequently fail to head. In such cases try pinching off the ends of the branches after plants begin to bloom, so that only two or three fruits will set. Dust with slug shot to protect from bugs. One ounce for 1,000 plants; 6 ozs. to plant an acre.

Matures in about 120 days from sowing.

BLACK BEAUTY-This earliest and most desirable of Egg Plants has gradually superseded all other varities. The fruits which are borne freely on strong, stocky plants, are egg-shaped and grow to good size. The skin is a rich dark purple which does not fade when the fruits reach maturity. For plants see page 22 .

Postpaid pkt. $5 \mathrm{c} ; 1 / 2$ oz. $25 \mathrm{c}$; oz. $45 \mathrm{c} ; 1 / 4$ lb. $\$ 1.50$.

\section{KALE OR BORECOLE}

CULTURE-Generally sown from August 15th to October 15th, but frequently sown in the spring with satisfactory results. Sow either broadcast or in drills 18 inches apart, and give some cultivation, and they will yield greens throughout the winter. Two ounces plant 100 feet of drill; 8 to $10 \mathrm{lbs}$. to the acre broadcast, 5 to $7 \mathrm{lbs}$. in drills. Cover seed $1 / 2$ in. deep.

DWARF CURLED SCOTCH - A handsome, very finely curled, dwarf, spreading variety; foliage long and of an attractive bright green. Very hardy and of excellent flavor.

Postpaid, pkt. $5 \mathrm{c}$; oz. $10 \mathrm{c} ; 1 / 4$ lb. $25 \mathrm{c}$; lb. $75 \mathrm{c}$.

DWARF CURLED SIBERIAN-A hardy, vigerous and spreading variety; leaves are large and rather plain in the center, but cut and frilled at the edges; color is a bluish-green.

Postpaid, pkt. $5 \mathrm{c}$; oz. $10 \mathrm{c}$; $1 / 4$ lb. $25 \mathrm{c}$; lb. $75 \mathrm{c}$.

TALL CURLED SCOTCH-Plants of this variety grow 2 to $3 \mathrm{ft}$. in height, bearing long, plume-like, light green leaves, which are much cut and deeply curled at the edges; very hardy.

Postpaid, pkt. $5 \mathrm{c}$; oz. $10 \mathrm{c} ; 1 / 4 \mathrm{lb} .25 \mathrm{c} ; \mathrm{lb} .75 \mathrm{c}$.

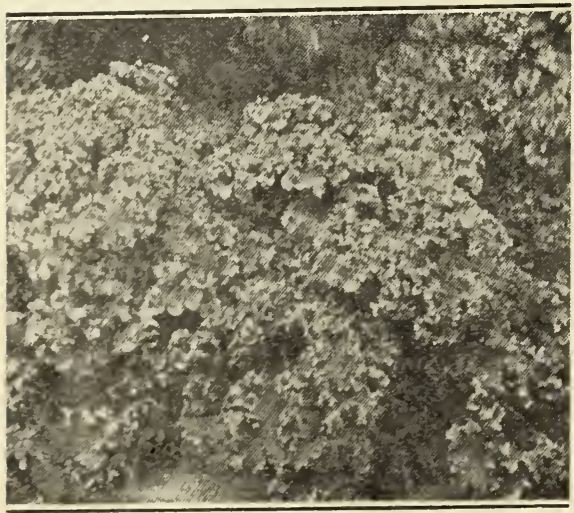

Dwarf Carled Scotch Kalo

\section{ENDIVE}

CULTURE-One of the best salads for fall and winter use. Endive is not only much used for salads and garnishing, but is also desirable for greens and for flavoring soups and stews.

Plants may be grown at any season of the year but are more generally used late in the fall. For early use sow from March 15th; for fall supply sow in June through September in drills fourteen to twenty inches apart and when well started thin the plants to one foot apart. When nearly full grown tie the outer leaves together over the center in order to blanch the heart of the plant. By covering fresh plants every few days a succession may be kept up.

One ounce sows $200 \mathrm{ft}$. of drill. Cover $1 / 4 \mathrm{in}$. deep.

MOSS GREEN CURLED-A very hardy medium green curled leaved sort, crisp and tender: blanches creamy white. The preferred and much the best variety.

Postpaid, pkt. $5 \mathrm{c}$; oz. $15 \mathrm{c} ; 1 / 4$ lb. $45 \mathrm{c} ; \mathrm{lb} . \$ 1.25$.

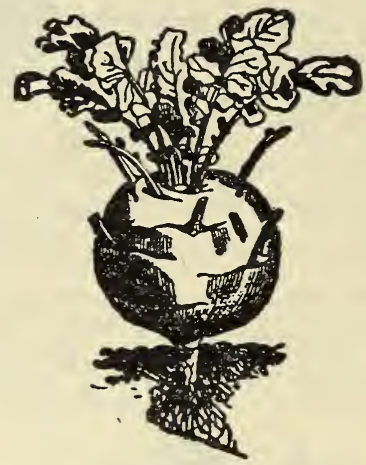

White Vienna Kohl-Rabi

\section{KOHL-RABI}

CULTURE-The edible part is the turnipshaped bulb formed above ground. It is tender and excellent when used before fully grown, combining somewhat the flavors of cabbage and turnip. Seed should be sown in light, rich soil as early in spring as possible in rows one and onehalf feet apart and when well established, thin to six inches apart in the row. Plantings at intervals of ten days will give a succession until hot weather, when they fail to grow well. Plantings may be made the latter part of July for fall use. Sow $1 \mathrm{oz}$. to $100 \mathrm{ft}$. of drill. Cover $1 / 2$ in. deep.

EARLY WHITE VIENNA-Extremely early, with distinctly small tons; bulbs medium size, very light green or nearly white and of best quality. Worthy of a place in any garden.

Postpaid, pkt. $5 \mathrm{c}$; oz. $20 \mathrm{c}$; $1 / 4$ lb. $65 \mathrm{c}$.

\section{HORSE RADISH ROOTS}

Horse Radish rarely produces seed, but is grown from pieces of the roots. Mark off the rows $31 / 2$ ft. apart, in rich, moist, well-prepared ground, and set the pieces of roots 18 inches apart in the rows vertically, the small end down, and the top 1 to 2 inches below the surface. Cultivate thoroughly until the tops cover the ground, when their shade will keep down the weeds. See Page 22 for prices. 


\section{LETTUCE SEED}

CULTURE-Sow in hotbeds $1 / 4$ in. deep in February and March, harden off and set out 8 to 12 inches apart in 18 inch rows. For succession, sow every 3 weeks. Sowing may be made in open ground early in the Spring and the plants thinned out. Lettuce is easy to grow, but requires rich, moist soil, clean and thorough cultivation, and plenty of water to give it that quick growth on which depends its tenderness and flavor. After plants are set out, a side-dressing of Nitrate of Soda will stimulate their growth.

For fall use plant in July and August. Plant the hardy kinds in September and October. Protect with straw or litter and they will head up in the spring. One ounce will sow about $100 \mathrm{ft}$. of drill or produce about 1500 plants. About $2 \mathrm{lbs}$. will make plants enough for an acre.

\section{Grand Rapids}

The favorite loose-leaved forcing lettuce and the best to sow outside in the spring and fall for family use. Leaves short, spatulate in shape, excessively blistered and crumpled and the border heavily fringed; color very light green, with no trace of brown. Grows very rapidly and keeps in good marketable condition for a long time after cutting. A most handsome and attractive lettuce and deservedly popular.

Postpaid pkt. 5c; oz. $15 \mathrm{c}$; $1 / 2$ lb. $45 \mathrm{c} ;$ lb. $\$ 1.50$.

\section{Big Boston}

Very popular for outside for summer and fall use as well as cold frame forcing. Head large and compact, leaves broad, almost smooth, but wavy at the edge; color light green, slightly tinged reddish-brown, heart greenish tinged yellow. Big Boston gives the best of satisfaction under all conditions and is a favorite with home gardeners, and as it ships well, is largely raised by truckers.

Postpaid pkt. $5 \mathrm{c}$; oz. $15 \mathrm{c} ; 1 / 4$ lb. $45 \mathrm{c} ; \mathrm{lb} . \$ 1.50$.

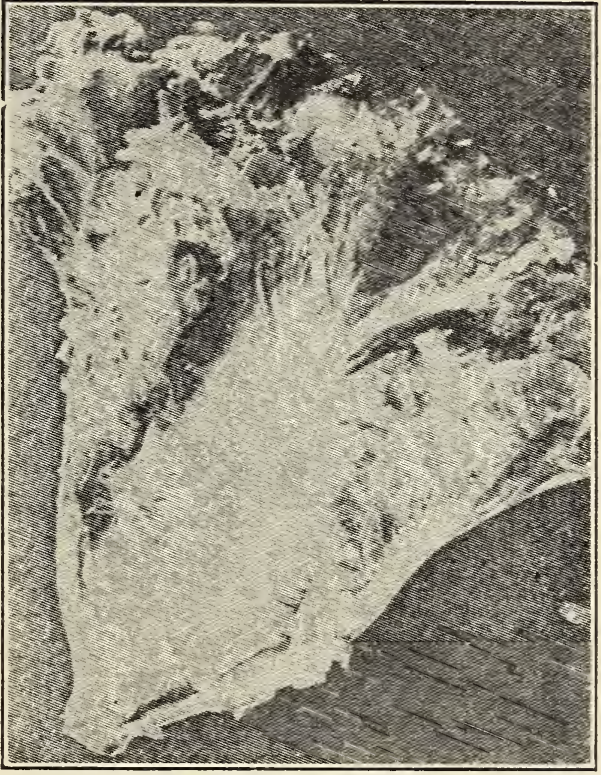

Grand Rapids Lettuce

\section{Iceberg}

A large, late, crisp cabbage heading variety; heads very firm, hard and well blanched, leaves broad, fairly blistered and crumpled, borders finely frilled; color medium green with faint brown tracing on the border. Quality is the best. Adapted for late fall sowing.

Postpaid pkt. 5c; oz. 20c; 1/t lb. 50c; lb. $\$ 1.75$.

\section{New York or Wonderful}

A very large, late globular heading variety; leaves broad, of thick texture, fairly blistered and crumpled and the borders frilled; color dark green. The quality is excellent and as it is a reliable grower in almost every soil, it can be highly recommended. Known in California and the West as "Los Angeles," and shipped east under the trade name of "Iceberg." Splendid for late fall sowing. Postpaid, pkt., 5c ; oz., 25c ; $1 / 4$ lb., $75 \mathrm{c}$ : lb., $\$ 2.25$.

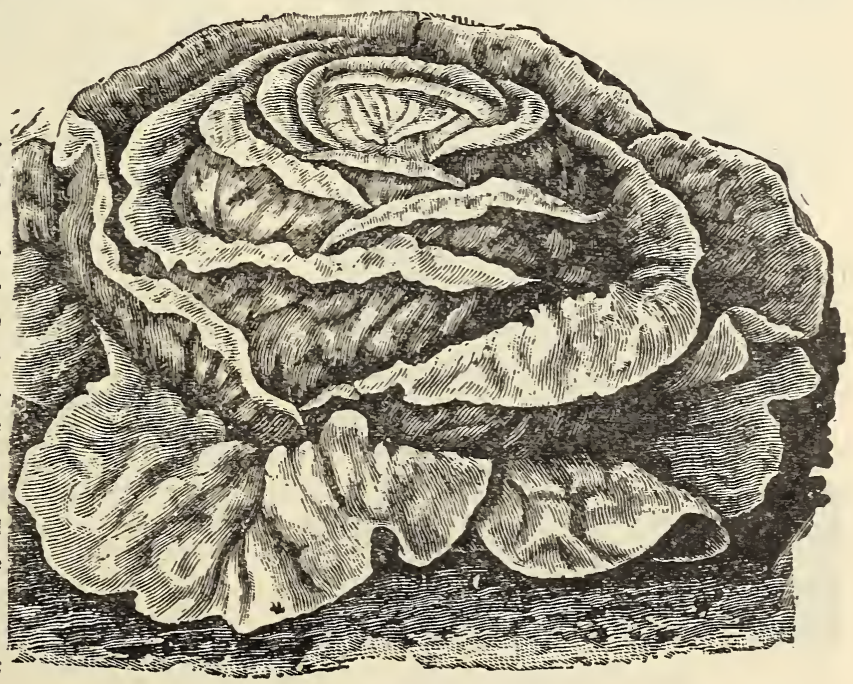

Big Boston Lettuce 


\section{MUSKMELON OR CANTALOUPE}

\begin{abstract}
CULTURE-A rich, sandy soil and good seed are a b s o lutels essential for success in raising the best muskmelons. The seed should not be planted until the ground has become dry and warm: plant in bills 4 to $6 \mathrm{ft}$. apart each way: old well rotted manure or sheep fertilizer should b e thoroughly mixed with the soil in each hill and in liberal quantity. Add a good commercial fertilizer and make the hills rich. Put from 10 to 16 seeds to the hill, 1 in. deep, and when danger of insects destroying the young plants is past, thin out, leaving 4 strong plants to the hill. Give frequent but shallow cultivation until vines cover the ground. Spray with Dowco, or a mixture of Arsenate of Lead and Bordeaux. Applications of Tobacco Dust will also do a great deal of good. A radish plant grown in each hill will help to keep the bugs away. One ounce will plant $\mathbf{5 0}$
\end{abstract} hills ; 2 lbs. to an acre.

\section{Salmon-Tint Rocky Ford}

Pollock's $10-25$ is the best of the Rocky Ford type of melons. The melons are solidly netted, without ribs, very uniform in size and shape, do not develop soft spots and can be picked closer than any other type of Rocky Fords. The flesh is a rich salmon about two thirds of the depth, changing to green near the rind. This color is very uniform.

Pkt. $5 \mathrm{c} ;$ oz. $10 \mathrm{c} ; 1 / 4$ lb. $35 \mathrm{c}$; lb. $\$ 1.25$.

\section{Banana Cantaloupe}

Shaped somewhat as the name indicates; grows about 24 inches long: flesh deep salmon color. Has a banana flavor. This melon does well in this section and is very popular with a great many growers. Postpaid, pkt. 5c; oz. $10 \mathrm{c} ; 1 / 4 \mathrm{lb}, 35 \mathrm{c}$; lb. $\$ 1.25$,

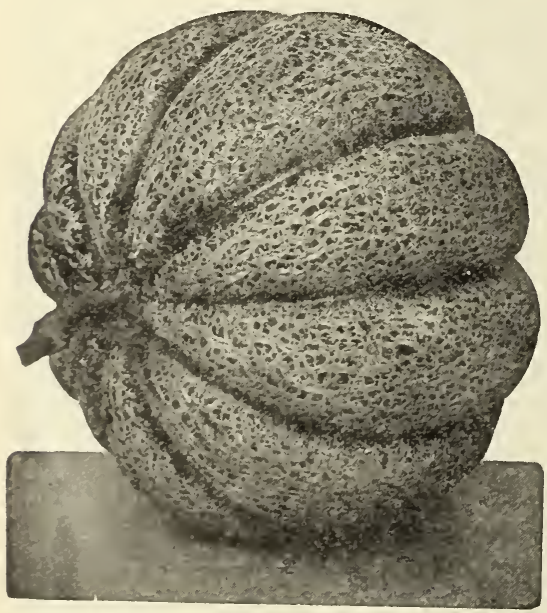

Hoodoo (Hearts of Gold)

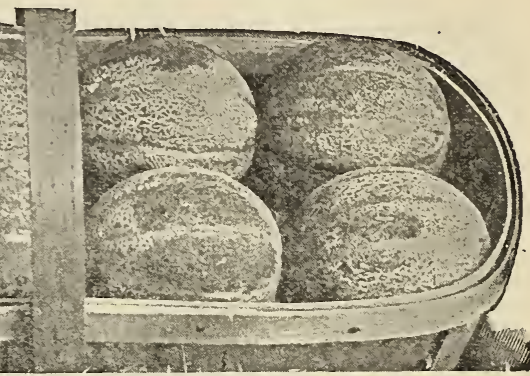

Gold Lined Rocky Ford

A round type of Rocky Ford; entirely covered with fine netting and without ribs. The flesh is a rich salmon color at the center shading to light green at rind. The seed cavity is small and the meat thick and of excelient flavor. This fine melon, known also as Eden Gem, does exceptionally well in this section and is very popular.

Postpaid, pkt. $5 \mathrm{c}$; oz. $10 \mathrm{c} ; 1 / 4$ lb. $35 \mathrm{c} ; \mathrm{lb}$. $\$ 1.25$.

\section{Hoodoo, Hearts of Gold}

A splendid, small, mid-season variety; fruit round, with tendency to heart-shape, densely covered with fine gray netting and distinctly ribbed. flesh very thick, ripening, thoroughly to the rind, with small seed cavity; of a rich orange color and highest quality. A fine shipping sort. Try this melon; you will like it.

Postpaid, pkt. 5c; oz. $10 \mathrm{c} ; 1 / 4$ lb. $35 \mathrm{c} ;$ lb. $\$ 1.25$.

\section{Tip Top}

A netted type melon, and a most excellent main crop sort. Fruit large, gray-green in color, round, flattened at ends, distinctly ribbed and well netted; flesh very thick, deep salmon color, and of the highest quality; a fine melon for home or market.

Postpaid, pkt. 5c; oz. $10 \mathrm{c}$; $1 / 4$ lb. $35 \mathrm{c}$; lb. $\$ 1.25$.

\section{Honey Dew}

This late variety has become extremely popular on account of its large size and excellent quality. The fruit is oval in form, about 10 inches long and 8 inches in diameter: surface smooth and hard, without ribbing or netting; creamy white in color, turning to lemon tint when fully ripe; flesh light emerald green : very thick, ripening to the rind; very tender with an extreme sweetness found in no other melon. An excellent variety for storing.

Postpaid, pkt. $5 \mathrm{c}$; oz. $10 \mathrm{c} ; 1 / 4$ lb. $35 \mathrm{c}$; lb. $\$ 1.25$.

\section{CRESS}

WATER CRESS-A hardy plant which can easily be grown in a shallow pond of fresh water or along the edges of shallow running streams. Seed may be readily started in pans or boxes of very moist earth. When the young plants are well grown, they should be transplanted to the stream or pond.

Postpaid, pkt. $10 \mathrm{c}$; $1 / 2$ oz. $20 \mathrm{c}$; oz. 35c.

UPLAND CRESS - Extra Curled (Peppergrass.) A small, curled plant, having a fine pungent flavor and used as a salad. Sown in the spring, 1 oz. to about $200 \mathrm{ft}$. of drill, about one ft. apart. Postpaid, pkt., 5c ; oz., 10c ; $1 / 4$ lb., $25 \mathrm{c}$. 


\section{SOUTHERN GROWN WATERMELON SEED}

\begin{abstract}
THE WATERMELL ON SEED WE OF. FER IS SOUTHERN GROWN AND PRO. DUCED BY AN EX. PERT WHO DEVOTES HIS ENTIRE TIME TO THE BUS. INESS. SEED OF THIS KNND IS MORE EXPENSTVE THAN ORDINARY STOCK BUT RESULTS MORE THAN $J U S T$ I F Y THE SLIGHT ADDITION. AL COST. YOU WILL BE PLEASED WITH THIS SEED.

CULTURE - Prepare the soil by thoroughly working in well rotted manure, pulverized sheep manure or poultry droppings; rich soil gives the plants a good start before insects attack them. Results will justify the use of plenty of highgrade commercial fertilizer, in addition to composte. Make hills $8 \mathrm{ft}$. apart each way, plant 10 to 12 seeds to a hill, covering 1 inch deep; when well up, thin out, leaving 3 strong plants to a hill. Spray with Dowco, or a mixture of Arsenate of Lead and Bordeaux. Applications of Tobacco Dust will also do a great deal of good. A radish plant grown in each hill will help to keep the bugs away. One ounce will plant 30 hills;
\end{abstract} 3 lbs, to an acre.

\section{Georgia Rattlesnake}

Is an elongated gray with light green stripes; an excellent shipper, vines vigorous and produetive. Flesh red and sweet, seeds white with black tips. Time for ripening about 80 days. Average weight 25 pounds.

Postpaid, pkt. 5c; oz. $10 \mathrm{c} ; 1 / 4$ lb. $25 \mathrm{c}$; lb. $90 \mathrm{c}$.

\section{Halbert's Honey}

This melon is dark green, slightly ridged and blunt at both ends, the flesh is very sweet and melting, leaves no trace of pulp; bright crimson; not a good shipper. Rind very tender; grows very long in shape: small white seeds with black tips: time for ripening about 85 days. Average weight 25 pounds.

Postpaid, pkt. 5c; oz. $10 \mathrm{c}$; $1 / 4$ lb. $25 \mathrm{c}$; lb. $90 \mathrm{c}$.

\section{Tom Watson}

One of the best melons either for market or home use; very prolific, attains a larger size than any of the long green melons, frequently growing 50 or 60 pounds in weight; no tipped ends or necks to rot: one of the best shippers. The rind is thin but tough, flesh deep red; tender, firm and sweet; produces melons 18 to 24 inches long by 10 to 12 inches in diameter; seeds light brown, smeared with darker brown; time for ripening about 90 days.

Postpaid, pkt. $5 \mathrm{c}$; oz. $10 \mathrm{c} ; 1 / \frac{1}{4} \mathrm{lb} .25 \mathrm{c} ; \mathrm{lb} .90 \mathrm{c}$

\section{STONE MOUNTAIN}

A new round watermelon showing slight ribes or lobes like a cantaloupe. The color of the smooth skin is light green. The flesh is uniform, beautiful, deep crimson without any white hearts or stringiness. The fruit averages about 45 pounds. The rind is too tender to permit long distance shipping, but for home and local market, it has no equal. It is very prolific and exceptionally sweet. The seeds are white with black points or tips; in some cases there are black spots on the sides; time for ripening about 100 days.

Postpaid, pkt. $5 \mathrm{c}$; oz. $15 \mathrm{c} ; 1 / 4$ lb. $40 \mathrm{c} ; \mathrm{lb}$. $\$ 1.25$.
Tom Watson Watermelon

Improved Kleckley Sweet

This watermelon is known locally as Red River, it is very popular and does exceptionally well in this section. Dark green skin, thin rind; flesh bright scarlet, solid, very sweet and crisp; not a good shipper for long distance. The fruits are oblong and uniform in size; seeds cream with an occasional seed smeared with brown; time for ripening about 85 days; average weight 25 pounds.

Postpaid, pkt. $5 \mathrm{c}$; $\overline{\mathrm{oz}} .10 \mathrm{c} ; 1 / 4$ lb. $25 \mathrm{c} ; \mathrm{lb} .90 \mathrm{c}$.

\section{Peerless or Ice Cream}

This melon has become a favorite with a great many; flesh deep crimson and fine grained, excellent quality, dark mottled green rind, shape oblong. Seed cream white, some smeared with brown. Time for ripening about 85 days. Average weight 30 pounds. Is is one of the finest quality melons grown, especially for the home grower.

Postpaid, pkt. $5 \mathrm{c}$; oz. $10 \mathrm{c}$; $1 / 4$ lb. $25 \mathrm{c}$; lb. $90 \mathrm{c}$.

\section{OKRA OR GUMBO}

CULTURE-Grown for its green seed-pods, which are used in soups or stewed and served a vegetable. Can be cured like dried apples and then used for soup at any time. When the all has become warm, sow thickly in rows $3 \mathrm{ft}$. apart, and when large enough, thin out to a foot apart in the rows. One ounce will sow $30 \mathrm{ft}$. of row: 8 to $10 \mathrm{lbs}$. to the acre. Cover 1 in. deep.

\section{Extra Early Dwarf}

An extra early maturing variety. Very productive. Plants are more dwarf in habit of growth than those of other varieties. Pods short, deep green, slightly corrugated, tender and of good quality. Postpaid, pkt. $5 \mathrm{c}$; oz. $10 \mathrm{c} ; 2$ oz. 15c ; $1 / 4$ lb. $25 \mathrm{c}$; lb. $75 \mathrm{c}$.

\section{White Velvet}

The plants are about three and one-hale feet high, early maturing and very productive. The pods are white, long, smooth and are tender until nearly full sized. Postpaid, pkt. $5 \mathrm{c}$; oz. $10 \mathrm{c}$; 2 oz. $15 \mathrm{c} ; 1 / 4$ lb. $25 \mathrm{c}$; 1b. $75 \mathrm{c}$.

Perkins' Mammoth (Long Green)

This variety is about three feet high, vers early and productive. The pods are deep green, very long, slender, slightly corrugated, ver tender and of good quality. This is destrable market as well as home garden sort. Postpaid. pkt. 5c; 0z. $10 \mathrm{c} ; 2$ oz. $15 \mathrm{c}$; $1 / 4$ lb. $25 \mathrm{c}$; lb. $75 \mathrm{c}$ 


\section{MUSTARD}

CULTURE-It is used the same as spinash or boiled with meats as greens. Sow in February, March or April, or in September and October, either broadcast or in rows six inches apart. One ounce sows 80 feet of drill; 5 to $6 \mathrm{lbs}$. broadcast to an acre, covering $1 / 2$ in. deep.

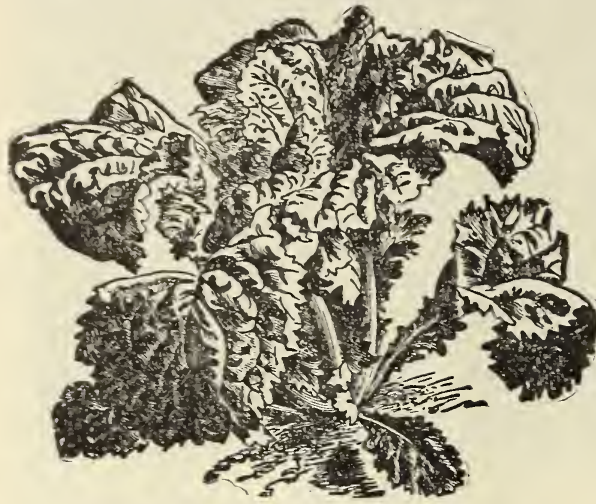

Southern Giant or Curled Mustard

SOUTHERN GIANT CURLED-Plants vigorous and hardy, of upright, spreading growth; leaves large, light green-tinged yellow, much erumpled and frilled at the edges. Succulent, pungent, and of 8 weet flavor. The most popular with Southern growers.

Postpaid, pkt. $5 \mathrm{c}$; oz. $10 \mathrm{c}$; $1 / 4$ lb. $25 \mathrm{c}$; lb. $75 \mathrm{c}$.

CHINESE BROAD LEAF-Plants rather tall and upright growing and produce considerably more leaf growth than other varieties. The leaves are large, broad, comparatively smooth and have broad, distinct midrib. When cooked the leaves are of excellent quality. The rariets is distinct in that it stays in condition witbout bolting to seed considerably longer than otherm.

Postpaid, pkt. 5c; oz. $10 \mathrm{c}$; 1/4 lb. $20 \mathrm{c} ; 1 \mathrm{~b} .75 \mathrm{c}$.

\section{ONION SETS}

CULTURE-One quart will plant about 30 feet of row; 12 to 15 bushels an acre. Plant 2 to 4 inches apart in rows 12 to 18 inches apart; set the onions right side up $1 / 2$ inch to 1 inch deep cover and firm dirt down. Soil should be rich and what is known as quick growing soil with plenty of old, well-rotted stable manure, sheep manure or a commercial fertilizer, containing a high percentage of potash. Onions must be kept free from weeds. All varieties can be set out in the fall as well as early spring.

SILVER SKIN-Produce earliest green onions. Postpaid, qt. $35 \mathrm{c}$; gal. $\$ 1.00$; peck $\$ 1.50$.

YELLOW DANVERS-Standard for color in most markets. Postpaid, qt. $35 \mathrm{c}$; gal. $\$ 1.00$; peck, $\$ 1.50$.

WHITE MULTIPLIER-Very productive and of the finest flavor, matures very early, producing a cluster of good sized onions from a single set. No onion keeps better.

Postpaid, qt. $35 \mathrm{c}$; gal. $\$ 1.00$; peck $\$ 1.50$.

YELLOW POTATO-The old original English multiplier. Make a large onion every other year Sets produce big onions and big onions produce sets. Postpaid, qt. $35 \mathrm{c}$; gal. $\$ 1.00$; peck $\$ 1.50$.

When larger quantities of Onion Sets are desired, please write for prices.

\section{ONION SEED}

CULTURE-Sow in spring as early as sroond can be worked. Soil mut be rich, thorourhls clean and pulverized. Use well rotted stable mse nure, sheep manure, or a commercial fertilizer containing a high percentage of potash. Sow in rows 12 to 18 inche apart, covering one-half inch and when seedlings are 3 to 4 inches tall, thes should be thinned to stand 3 to 4 inches spart in the row. Onions must be kept free from weeds. For raising sets and onions for pickling, row should be 10 to 12 inches apart. Lato plantings are made in August and September. One ounos sows 100 feet of row; 5 to 6 lbs. to the acre. For growing pickling onions use 25 to $80 \mathrm{lbs}$. to the acre; for sets 40 to 50 lbs.

PRIZETAKER-One of the largest, handsomest and most profltable onions grown. It is strictly "fancy" and is sold on fruit stands in the fall a "Spanish" onion. Prizetaker is globe-shape hes pale yellow skin and white flesh, which is very mild and of pleasantly pungent flavor. Bulbe will grow to enormous size if seed is sown under glass in February and seedlings transplanted into rich soil outdoors as soon as weather permits.

Postpaid, pkt. $5 \mathrm{c}$; oz. $25 \mathrm{c} ; 1 / 1$ lb. $75 \mathrm{c}$; lb. $\$ 2.25$.

SILVER SKIN OR WHITE PORTUGAL-A large flat, white onion of mild and pleasent is vor: hard and flne grained. Silver Skin is tensively grown for sets and is also largely used for pickling onions. A splendid variety for the home or market garden and for green onions.

Postpaid, pkt. $5 \mathrm{c}$; oz. $25 \mathrm{c} ; 1 / 4$ lb. $75 \mathrm{c} ; \mathrm{lb}$. $\$ 2.25$.

YELLOW GLOBE DANVERS-The best know and most largely grown yellow onion. The balb are medium to large size, averaging about 2 inches in diameter, uniformly glob shape, hav small necks and ripen evenly. The skin in light yellow; flesh is creamy white, crisp and mild is flavor. A fine keeper, matures early and is uni versally recommended for general crop and for growing sets. The standard in most markets.

Postpaid, pkt. $5 \mathrm{c}$; oz. $25 \mathrm{c}$; $1 / 4$ lb. $75 \mathrm{c}$; lb. $\$ 2.25$.

LARGE RED WETHERSFIELD-The mot generally grown and best known red variety. The bulbs are large, somewhat flattened; std purplish red; flesh purplish white; very hare and solid; an excellent keeper and a hear crop per. A rood onion for poor and dry soil and fer growing sets but not as popular as formerly.

Postpaid, pkt. $5 \mathrm{c}$; oz. $20 \mathrm{c}$; $1 / 4$ lb. $60 \mathrm{c} ; \mathrm{lb} . \$ 2.00$.

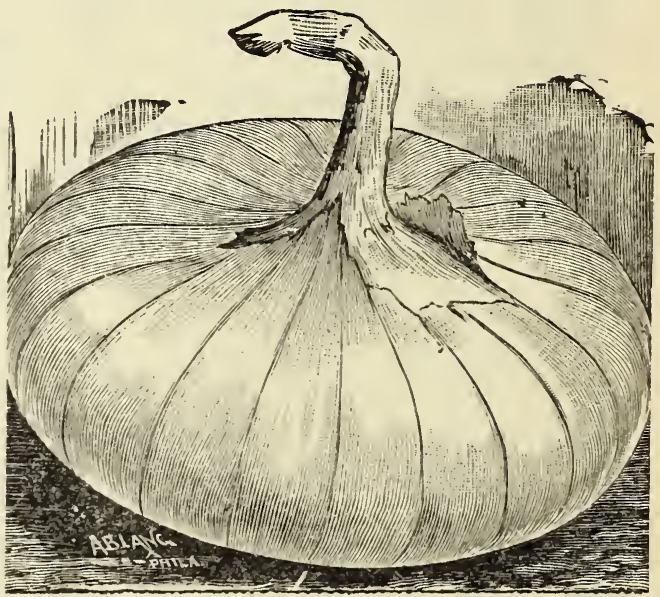

Silver Skin or White Portagal Onion 


\section{PEPPER SEED}

Peppers are used for seasoning meat and vegetable dishes, for salads or as mangoes. Sow seed early in hot beds $1 / 4$ inch deep or in open seed bed when ground is warm in light soil. When about 3 inches high transplant in rows 18 inches apart. 2 feet apart in the rows. Keep free from weeds and fertilize when about 6 inches high. Poultry droppings are particularly valuable to use. One ounce will produce 1000 plants.

PIMENTO-Sweetest pepper grown, a very thick fleshed, heart-shaped, mooth mild crimson variety, much used for salads; very prolific.

Postpaid, pkt. 5c; oz. $30 \mathrm{c}$; $1 / 4$ lb. $90 \mathrm{c}$

RUBY KING-This is a fine variety, growing from 4 to 6 inches long, and 3 to 4 inches thick. The flesh is very thick, mild and pleasant to the taste. It is a fine sort for stuffing or for pepper hash, and also makes an excellent dish for salad. Postpaid, pkt. $5 \mathrm{c}$; oz. $30 \mathrm{c}$; $1 / 4$ lb. $\$ 1.00$.

LARGE BELL OR BULL NOSESometimes called Sweet Mountain. The plants are vigorous, about two feet high, compact, and very productive, ripening their crop uniformly and early. The fruits are 3 in. long, 2 in. diameter, thick, mild flavored, and of excellent quality. The color is deep green when fruit is young, bright crimson when ripe. One of the best varieties for mangoes or stuffed peppers. Postpaid, pkt. 5c; oz. $30 \mathrm{c}$; $1 / 4 \mathrm{lb}$. $\$ 1.00$.

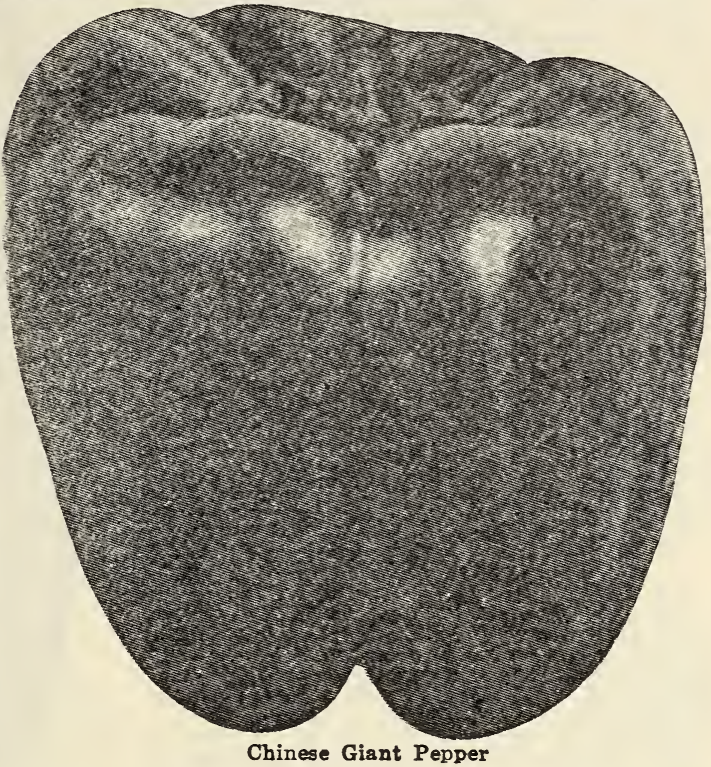

CHINESE GIANT-One of the very largest of the mild red varieties. Plant of short, stocky growth, with light green foliage; fruits pendent, thick, blocky and square ended, 4 to 5 inches in diameter and of equal length; color, brilliant glossy scarlet. One of the very best varieties for salads and large mangoes.

Postpaid, pkt. 5c; oz. 50c; $1 / 4$ lb. $\$ 1.75$.

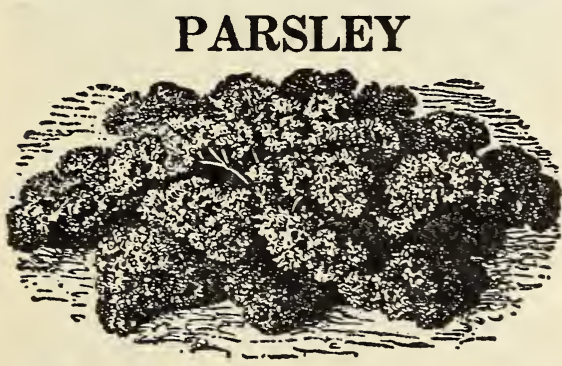

CULTURE-This well known plant is very useful for flavoring soups and stews and for garnishing. One ounce sows 100 feet. Sow both Spring and Fall.

Parsley succeeds best on rich, mellow soil. The seed is even slower than parsnip in germinating and should be sown as early as possible in the spring, in drills one to two feet apart covering not more than one-half inch with fine soil firmly pressed down. When the plants are well up thin to stand four to six inches apart in the row. When the plants are about three inches high cut off all the leaves; the plant will then start a new Erowth.

A few radish seeds should be sown in the row with parsley to mark the row and allow early cultivation. The radishes can be pulled early and will not interfere with the parsley. Top dress with well rotted manure or sheep fertilizer. Fall

LONG RED CAYENNE-This is a fine, slender variety, about 4 in. long, often curved and twist. ed, very hot, bright red, and of exceedingly pungent flavor as a seasoner. It is a good keeper. When fully ripe can be gathered, dried and strung for winter use.

Postpaid, pkt. 5c; oz. $30 \mathrm{c}$; $1 / 4$ lb. $\$ 1.00$.

PEPPER PLANTS-See Page 22.

sowings can be made as late as October in hot beds or cold frames.

CHAMPION MOSS CURLED-The best and most improved strain of Parsley. It is beautifully curled and crimped, and is best for garnishing and fiavoring. If cut when about 3 inches high, it starts a new growth that will be better curled and a brighter color. It makes an ornamental plant for edging walks.

Postpaid, pkt. $5 \mathrm{c}$; oz. $10 \mathrm{c} ; 1 / 4$ lb. $30 \mathrm{c}$; lb. $\$ 1.00$.

\section{PARSNIP}

CULTURE-Plant as early in the spring as the weather will permit till the middle of June. Plant $1 / 2$ inch deep in a rich, deeply worked, sandy loam, in rows, 18 inches apart, cover light$1 y$, and when 2 inches high thin out to 4 to 6 inches apart. Parsnips germinate slowly, especially in dry weather; plant a few radish seeds with them to mark the row for early cultivation. Parsnips are improved by frost so they can be dug as wanted, or stored for winter use. One ounce sows 20 feet of drill; 5 to 6 lbs. sows an acre.

SUGAR OR HOLLOW CROWN-Better known and more generally grown than any other sort roots smooth, usually 15 inches long by 3 inches in diameter at the top; tender and sugary.

Postpaid, pkt. $5 \mathrm{c}$; oz. $10 \mathrm{c} ; 1 / 4$ lb. $30 \mathrm{c}$; lb. $90 \mathrm{c}$ 


\section{GARDEN OR ENGLISH PEAS}

(Varieties Marked With Star $\left(^{*}\right)$ Are Wrinkled)

CULTURE - Plant the smooth varieties as early as the ground can be worked, 2 inches deep in double rows 6 to 8 inches apart, $21 /$ to $8 \mathrm{ft}$. between the double rows and stake the tall varieties with brush. The wrinkled peas are not as hardy as the smooth sorts and they should be planted later; they are sweeter and better flavored. They should be kept clean and the earth worked toward them 2 or 3 times during the growth. For a continuous crop, plant every 2 weeks as late as August for a fall crop. Gather as fast as they are big enough to use, otherwise they will stop bearing. Peas mature earlier in a light, rich soil; for general crop, a moderately heavy soil is best. Two lbs. will plant $100 \mathrm{ft}$. of row; 90 to $100 \mathrm{lbs}$. per acre. Inoculate this seed with Stimugerm. Use plenty of good fertilizer.

\section{First and Best}

A standard extra early smooth pea. It is the hardiest, most prolific and profitable of the very early sorts. The well-filled pods containing usually 6 to 8 peas are of fair quality. Height $21 / 2 \mathrm{ft}$. Postpaid $1 / 2$ lb. $20 \mathrm{c} ; \mathrm{lb} .35 \mathrm{c} ; 2$ lbs. $60 \mathrm{c} ; 5$ lbs. $\$ 1.25$.

Not prepaid, $1 / 2$ lb. $15 \mathrm{c}$; lb. $25 \mathrm{c} ; 5$ lbs. $\$ 1.00$.

\section{Alaska (Large Podded)}

Early, large, smooth, blue pea; large, broad dark green pods. Hardy, standing early planting. Uniform maturity and other distinct valuable qualities have made it popular with the gardeners and canners. A good early variety for the home garden. Height $3 \mathrm{ft}$.

Postpaid $1 / 2$ lb. 20c: lb. 35c: 2 lbs. 60c; 5 lbs. $\$ 1.25$. Not prepaid, $1 / 2$ lb. $15 \mathrm{c}$; lb. $25 \mathrm{c} ; 5$ lbs. $\$ 1.00$.

\section{Superb}

An early variety, especially fine for home and very popular with market gardeners. The foliage is a medium green and the pods a dark green. The pods are 4 inches long, pointed and somewhat curved. The seed is green and slightly wrinkled. Very prolific. Height 16 inches.

Postpaid, 1/ lb. 25c; lb. $35 \mathrm{c} ; 2$ lbs. $65 \mathrm{c} ; 5$ lbs. $\$ 1.40$.

Not prepaid, $1 / 2$ lb. $15 \mathrm{c}$; lb. $25 \mathrm{c} ; 5$ lbs. $\$ 1.15$.

\section{*Little Marvel}

An extra early fine dwarf sweet flavored pea, which is rapidly taking the place of some of the older and better known varieties. A fine variety for either private or market garden. Foliage and pods very dark green: pods 3 inches long, nearly round and square ended, containing 7 very dark green peas of high quality. Very productive. Height 14 in.

Postpaid, $1 / 2$ lb. 25c; lb. 35c ; 2 lbs. $65 \mathrm{c}$; 5 lbs. $\$ 1.40$

Not prepaid, $1 / 2$ lb. $15 \mathrm{c}$; lb. $25 \mathrm{c} ; 5$ lbs. $\$ 1.15$.

\section{*Blue Bantam}

A splendid large-podded, early, dwarf variets which does well in this section and is very popplar. Vine and foliage stout and healthy, medium dark green; pointed pods deep green, 4 in. long, broad and straight, containing 6 to 8 deep green peas of excellent quality. Heicht 15 in.

Postpaid, $1 / 2$ lb. $25 \mathrm{c} ;$ lb. $35 \mathrm{c} ; 2$ lbs. $65 \mathrm{c} ; 5$ lbs. $\$ 1.40$

Not prepaid, $1 / 2$ lb. $15 \mathrm{c}$; lb. $25 \mathrm{c} ; 5$ lbs. $\$ 1.15$.

\section{*Gradus, or Prosperity}

A standard, early large podded variety, very popular with market gardeners. Vine and foliage moderately heavy and medium green; pods medium green, $3 \% / 4$ in. long, semi-round, straight, slightly curved at the tip, and pointed, containing 6 to 8 large, very sweet, medium green peas: moderately productive and of high quality Height $21 / 2$ feet.

Postpaid, 1// lb, 25c : lb, 35c : 2 lbs, $65 \mathrm{c}$ : 5 lbs. $\$ 1.40$

Not prepaid, $1 / 2 \mathrm{lb}, 15 \mathrm{c} ; \mathrm{lb}, 25 \mathrm{c} ; 5$ lbs. $\$ 1.15$

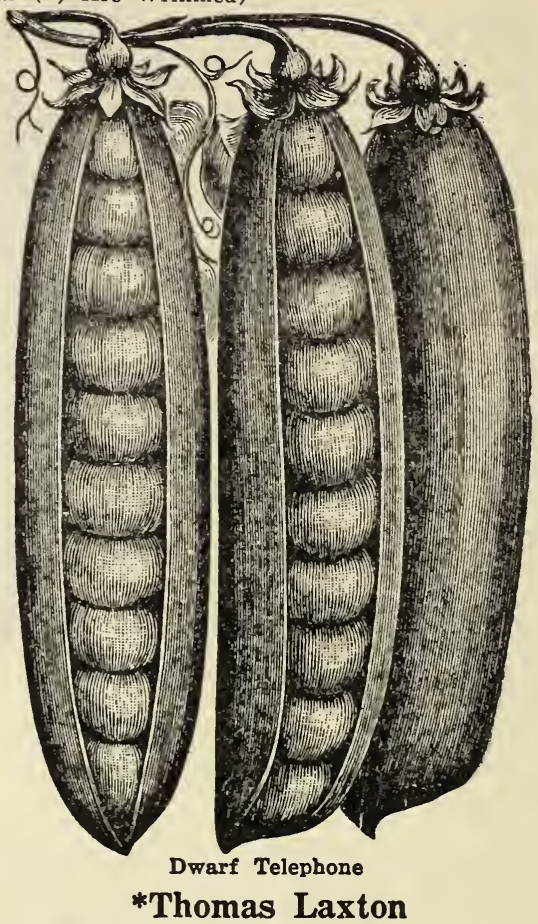

A very popular garnener's variety. Vine and foliage moderately stout, medium green: pods medium green $3^{1 / 2}$ in. long, straight, nearly round and square ended, containing 7 medium dark green peas of superior quality. Compared with Gradus, is a little earlier, more productive, but with a smaller, less broad pod. Height $2 \frac{1}{2}$ feet. Postpaid, $1 / 2$ lb. $25 \mathrm{c}$; lb. $35 \mathrm{c} ; 2$ lbs. $65 \mathrm{c} ; 5$ lbs. $\$ 1.40$.

Not prepaid, $1 / 2$ lb. $15 \mathrm{c}$; lb. $25 \mathrm{c} ; 5$ lbs. $\$ 1.15$.

\section{*Dwarf Telephone}

An excellent second early and main crop variety. Vines and foliage dark green and exceptionally stout; pods dark green, $41 / 2$ in. long, straight and pointed; containing 8 to 10 dark green peas of the best quality. Height about 2 feet.

Postpaid, $1 / 2$ lb. $25 \mathrm{c}$; lb. $35 \mathrm{c}$; 2 lbs. $65 \mathrm{c} ; 5 \mathrm{lbs} . \$ 1.40$

Not prepaid, $1 / 2$ lb. $15 \mathrm{c}$; lb. $25 \mathrm{c} ; 5$ lbs. $\$ 1.15$.

\section{*Tall Telephone}

An old standard, high quality, large podded pea. Vine and foliage strong and heavy, medium green. Pods $4 \frac{1}{2}$ in. long, medium light green, straight, broad and pointed, containing 8 large, light green peas. A main crop and very productive variety. Height about $31 / 2$ feet.

Postpaid, $1 / 2$ lb. $25 \mathrm{c}$; lb. $35 \mathrm{c} ; 2$ lbs. $65 \mathrm{c} ; 5$ lbs. $\$ 1.40$.

Not prepaid, $1 / 2$ lb. $15 \mathrm{c}$; lb. $25 \mathrm{c} ; 5$ lbs. $\$ 1.15$.

\section{SALAD PEA}

MAMMOTH MELTING SUGAR-It is the very best edible pea obtainable. The large broad pods are of delicious sweet flavor, being very brittle and entirely stringless. Vine stout, medium green; pods light green, $3^{1} / 2$ in. long, 1 in. broad, nointed, containing 7 light green peas. Seed smooth and white. Season of Telephone. Height $3 \mathrm{~T} / 2$ feet. Postpaid, $1 / 2 \mathrm{lb} .25 \mathrm{c}$; lb. $45 \mathrm{c} ; 2$ lbs. $80 \mathrm{c}$.

Not prepaid, $1 / 2$ lb. $20 \mathrm{c} ; 1 \mathrm{lb} .35 \mathrm{c} ; 5$ lbs. $\$ 1.40$ 


\section{MAINE GROWN SEED IRISH POTATOES}

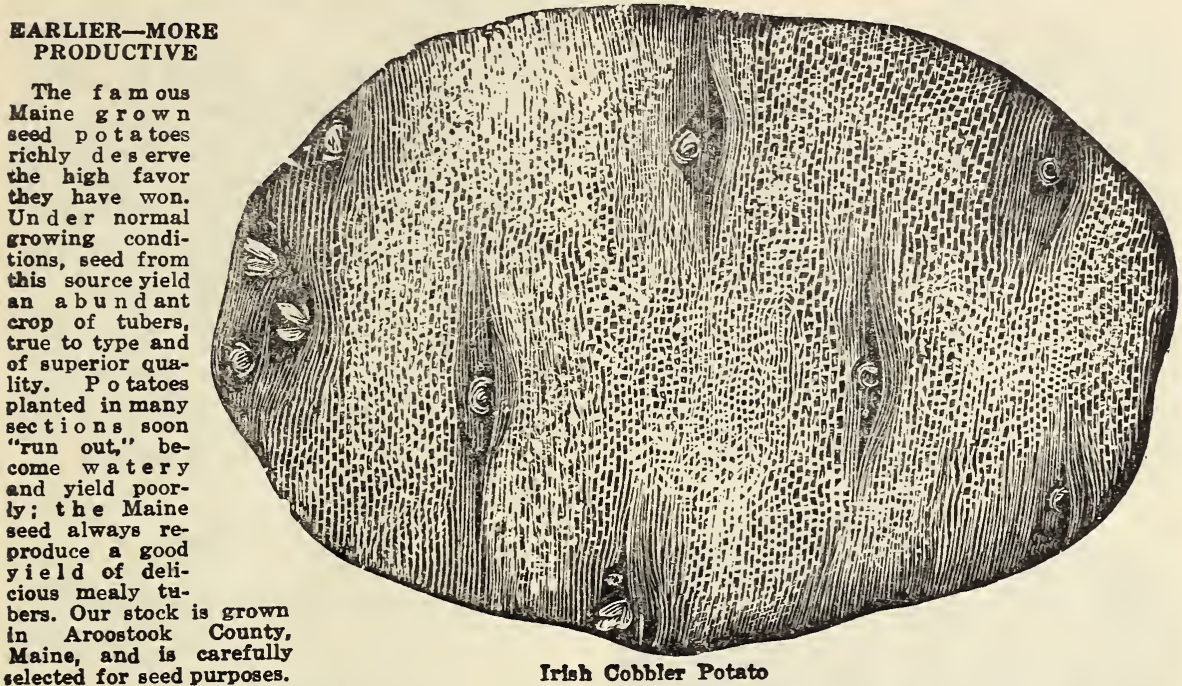

\section{Culture}

Potatoes do best in a rich sandy loam that contains plenty of vegetable matter; a clover sod or land that was heavily manured for the previous crop supply ideal conditions. Cut the potatoes, leaving two eyes to each piece, and plant 15 inches apart in three-foot rows, 4 inches deep for early plantings, 6 inches deep for later plantings : cultivate frequently to keep down the weeds and conserve moisture, for a shortage of moisture means a poor crop. Apply fertilizer either in the row or broadcast before the potatoes are planted, and be sure to work it into the soil so that it will not come in contact with and burn the potatoes. Do not use stable manure, as it means scabby potatoes. Continue cultivating till the plants attain full growth and the vines begin to spread.

One peck will plant about 100 feet of row, or 100 hills. Ten bushels are required to plant an acre.

See page 49 for fertilizers.

\section{To Prevent Potato Scab}

Before cutting the potatoes, put them in a burlap bag and dip them in the following solution, allowing to remain about two hours, dry before cutting: $4 \mathrm{oz}$. Corrosive Sublimate (Bichloride of Mercury) to 30 gals. of water. Dissolve first in small quantity of hot water. Dip whole bag in the solution and add Corrosive Sublimate when you put in more water. Use only in wood, enamel or concrete containers. BE CAREFUL! DEADLY POISON! Do not let anything eat potatoes after they are treated! Not prepaid $1 / 4$ lb. $75 \mathrm{c} ; \mathrm{lb} . \$ 2.50$.

\section{Insect Remedies}

For Blight spray with Bordeaux Mixture and when bugs appear, apply Arsenate of Lead, Copper Sulphate, Calcium Arsenate or Slug Shot, repeating treatment as often as necessary. Write for a Spraying Chart. See page 50 for Insecticides and fungicides.

\section{Early Red Bliss Triumph}

This is a very plump, smooth, pink-skinned potato that is very widely grown throughout the South. It is earlier than Cobbler and more productive than Rose, and therefore fills in between the two. Those who like a potato with a pink skin and white flesh, will find the Red Bliss most satisfactory. It peels without waste, is a fine yielder and is in great demand in a great many sections where its merits are appreciated and on account of its extreme earliness. Matures in about 110 days.

\section{Irish Cobbler}

This has been the standard white variety for many years, and it is hard to find another that can compare in looks or flavor. The skin is white and smooth; the potato symmetrical; flesh good clear white and mellow when cooked. It is the leading commercial variety and there are more Cobblers grown than all the other kinds put together. Its popularity is due not only to its extreme earliness-being ten to twelve days earlier than Early Rose-but is also based on its reputation as a reliable and uniform yielder. One of its strong characteristics is that it makes few if any very small potatoes, practically all being medium to large size, and one rarely sees a knotty Cobbler for they are generally plump handsome potatoes. Matures in about 115 days.

\section{Early Rose}

This is one of the most popular potatoes for the early market. Besides being early in maturing, it is very productive, and of excellent quality. The skin is pink and the flesh firm. They make a good appearance and are easily marketed. Very mealy and dry and keep well. Does better on poor land than most sorts. Matures in about 125 days.

\section{Green Mountain}

Possibly the best-known late Potato on the market. A prolific yielder, growing tubers of large size, oval and fine white flesh. The skin is a dull cream or light russet, the eyes are comparatively small and shallow. Most profitable Potatoes, for market or home use. There is no variety superior in quality to Green Mountain it has a delightful dry mealy flavor when cooked. A good variety to store for winter use.

After February 1st write us stating quantities and varieties you are interested in. 


\section{PUMPKIN SEED}

CULTURE-Pumpkins are rapidly growing in favor throughout the South. The larger and coarser sorts make excellent stock food while the majority of the sorts make excellent pies and are used in a number of other ways.

Pumpkins may be planted most any time during spring and early autumn among corn rows, or in the open. Plant in hills 8 to 10 feet part. mixing well-rotted manure in each hill. Put 8 to 10 seeds in each hill, 1 inch deep, and cultivate till the vines get strong, when they should be thinned out, leaving two or three of the strongest in each hill. When planted in corn, plant at the same time as the corn in every fourth row, 10 to 12 feet apart in the rows, letting the hill of pumpkins take the place of a hill of corn. Do not grow near squashes or melons. Keep off bugs by dusting with Slug Shot or Arsenate of Lead. One ounce will plant 20 hills, three pounds, one acre. Use a good commercial fertilizer containing a high percentage of Potash.

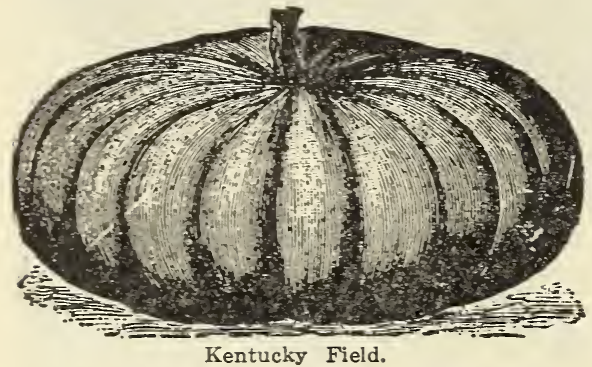

\section{Kentucky Field or Large Cheese}

A very popular Southern sort; large and flattened. A wonderful keeper; a good stock variety; a valuable eating and pie sort, also suitable for canning. Skin mottled light green and yellow, changing to a creamy yellow when they mature. Flesh yellow, tender, and of excellent quality. Postpaid, pkt. $5 \mathrm{c}$; oz. $10 \mathrm{c}$; $1 / 4$ lb. $30 \mathrm{c}$; lb. $90 \mathrm{c}$.

\section{Sweet or Sugar \\ (New England Pie)}

Fruit small, round, flattened at the ends, and slightly ribbed; skin and flesh deep orange yellow; flesh very thick and of high quality. It is not a large pumpkin, but one of the sweetest and best for pies. It is fine grained, deliciously sweet, and a very good keeper.

Postpaid, pkt. $5 \mathrm{c}$; oz. $10 \mathrm{c}$; $1 / 4$ lb. $30 \mathrm{c}$; lb. $90 \mathrm{c}$.

\section{Green Striped Cushaw}

This is one of the finest pumpkins in existence, a long, crooked neck, terminating in a round or oblong end, enclosing a very small seed cavity; flesh surrounding seed cavity is rich yellow: tender, very thick and of the best flavor. The neck is absolutely solid, rivaling the finest sweet potatoes for baking and as a pie sort it has no equal. Skin with mottled green and white stripes. Fruit will weigh from 10 to 15 lbs. A splendid keeper.

Postpaid, pkt. 5̌c; oz. 10c; $1 / 4$ lb. 40c; lb. $\$ 1.25$.

\section{King of Mammoth}

The giant among pumpkins; specimens have been grown to weigh 250 pounds and reaching two feet or more in diameter; fruit round and flattened, slightly ribbed; skin salmon-orange, flesh bright yellow and very thick. Grown only for stock feeding or as a curiosity.

Postpaid, pkt. 5c; oz. 10c; $1 / 4$ lb. $35 \mathrm{c} ; 1 \mathrm{lb} . \$ 1.25$.

\section{VEGETABLE PLANTS}

No plants or roots sent C. O. D. Prices subject to change without notice and goods being unsold.

\section{Cabbage Plants (Frost Proof)} Postpaid Prices.

100 to 400 plants 500 plants .................................. 1.50 per 500

1000 or more plants.............................22.50 per 1000

Cauliflower (Double Rooted)

SNOWBALL-Ready about March first.

Postpaid, doz. 40c; 50 for $\$ 1.50,100$ for $\$ 2.75$. Celery (Double Rooted)

Not ready until after June 15th

Postpaid, doz. 35c; 50 for $\$ 1.00 ; 100$ for $\$ 1.75$.

Egg Plant (Double Rooted)

BLACK BEAUTY-Ready May, June and July.

Postpaid, doz. 40c; 50 for $\$ 1.50 ; 100$ for \$2.75.

Peppers (Double Rooted)

Ready May and June.

Postpaid, doz. 40c; 50 for $\$ 1.50 ; 100$ for $\$ 2.75$.

\section{Sweet Potatoes}

Ready May and June. Ask for prices.

\section{Tomatoes (Double Rooted)}

Please refer to Page 25 for varieties handled.

In ordering please state your first, second and third choice as we are frequently sold out and unable to secure particular varieties. Ready April, May, June and July.

Postpaid, doz, 40c: 50 for $\$ 1.50 ; 100$ for $\$ 2.75$. Prices are for even quantities of one variety.

\section{HARDY ROOTS}

\section{Asparagus Roots}

MARY WASHINGTON (2-year size), Postpald. 50 for $\$ 1.25 ; 100$ for $\$ 2.00 ; 500$ for $\$ 7.00$.

Not prepaid, 50 for $\$ 1.00$; 100 for $\$ 1.75$; 500 for $\$ 6.50$.

\section{Horse Radish Roots}

Ready about February 15.

Postpaid, 25 for $50 \mathrm{c}$; 50 for $85 \mathrm{c}$; 100 for $\$ 1.60$.

\section{Rhubarb Roots}

Do best in a moist or shady place; set out early in the spring or fall in deep, well worked soil, \& ft. apart each way. Mix freely with manure or coarse litter. A barrel placed over the plants gives ideal protection from the sun and produce longer and more tender stalks. The best stems are produced the second year, but it continues to produce for several years. Apply plenty of maxure; sheep manure is a splendid fertilizer.

Plant in the fall or early spring.

Postpaid, 20c each; 8 for $50 \mathrm{c}$; doz. $\$ 1.7 \mathrm{~F}$

\section{HERB SEED}

CULTURE-Sow in early spring in drills 12 to 15 inches apart, and thin out young plants. Gather when just coming into bloom, tie in small bunches and dry in the shade.

DILL-An annual, cultivated for its seeds, which have an aromatic odor and a warm pungent taste. Used for flavoring soups, stews and pickles, being particularly desirable for use in cucumber pickles, as it heightens the flavor.

Postpaid, pkt. $5 \mathrm{c}$; oz. $10 \mathrm{c}$; $1 / 4$ lb. $30 \mathrm{c}$; lb. $\$ 1.00$.

LAVENDER-A perennial mostly grown for the sweet scented flowers which, when dried, are placed in the linen closet to impart their delicate perfume to the linen.

Postpaid, pkt. $10 \mathrm{c}$; $1 / 2$ oz. $30 \mathrm{c}$; or. $50 \mathrm{c}$

SAGE-A perennial and the most extensively used and most valuable of all herbs for seasoning. For the dressing in roasted fowls and for sausage, etc., sage is almost a necessity.

Postpaid pkt. $10 \mathrm{c} ; 1 / 2$ oz. $25 \mathrm{c}$; oz. $45 \mathrm{c}$ 


\section{RADISH SEED}

CULTURE-For an early supply sow in a not-bed in February, care being taken to give abundant ventilation to prevent running to leaves. For open-air culture and succession, sow from middle of March until September at in tervals of 10 days. Radish do best in a rich losmy soil and must be cultivated often snd thoroughly, as it is very important to mature the crop quickly, to retain their crisp, tender quality.

Sow 1 inch deep in drills 12 to 18 inches apart and thin out plants to to 6 inehes in the row. Can also be sown as a catch-crop between row of beets, lettuce, onions, ete., or somb in the same drill with slow-growing vegetables like earrots and parsnips.

Fertilize with sheep manure and side dress with Nitrate of Soda. Pull when ready as they be come pithy when allowed to stay in groond too long. One oz. 80 ws $50 \mathrm{ft}$. of drill; 9 to $10 \mathrm{Ibs}$. to an acre.

\section{Rapid Red}

The best and quickest growing round red radish and one of the slowest of this type to shoot to seed. Round bright scarlet and with the smallest possible top. Fine for the home garden or for the market; also one of the best forcing varieties. This is the biggest seller and most popular radish in this section. Postpaid, pkt. 5c; oz. 10c $1 / 4$ lb. $30 \mathrm{c}$; lb. $\$ 1.00$.

\section{Sparkler White Tip}

A splendid radish popular with private garden. ers as well as growers for the market. Practically the whole lower portion is white and the upper part is deep scarlet. It is larger, rounder and more showy than similar varieties and for this reason as well as for its many fine qualities, is a big seller on the stands; also adapted for forcing. Postpaid, pkt. $5 \mathrm{c}$; oz. $10 \mathrm{c} ; 1 / 1 \mathrm{lb} .30 \mathrm{c}$ : lb., $\$ 1.00$.

\section{French Breakfast}

The leading oblong or olive shape radish for market use or home garden. The flesh is white, firm, crisp, juicy, tender and mildly pungent. Tho skin is bright rose scarlet with small white tip. This variety is very early and a rapid grower either under glass or outdoors.

Postpaid, pkt. 5c; oz. 10c; $1 /$ lb. $30 \mathrm{c}$; lb. $\$ 1.00$.

\section{Cincinnati Market}

The leading long red radish, and one of the earliest. The roots when matured are 5 to 6 inches long and about one-half of an inch in dimeter. Being long standing, it is one of the most desirable varieties for outdoor summer planting for the home garden or market. It is also adapted for forcing. On the stand it will outsell any similar radish put in competition with it as it is brittle and crisp. Postpaid, pkt., $5 e$; oz. $10 \mathrm{c} ; 1_{ \pm}^{\prime} \mathrm{lb}$. $30 \mathrm{c}$ : lb. $\$ 1.00$.

\section{White Icicle}

The finest long white radish and considered by many the best radish in cultivation. The young radishes are ready for use in 25 days and continue to grow, fully retaining their crisp tenderness and mild flavor until quite large. These radishes are transparent white, have small tops. allowing close planting and are very erisp and brittle. A festure greatly in its favor is that it

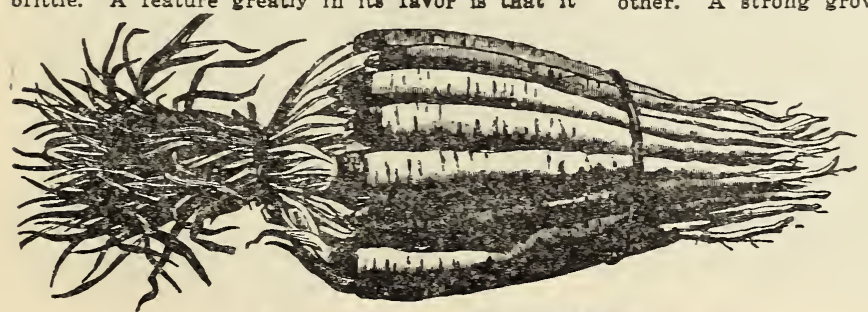

Mammoth Sandwich Island Salsify

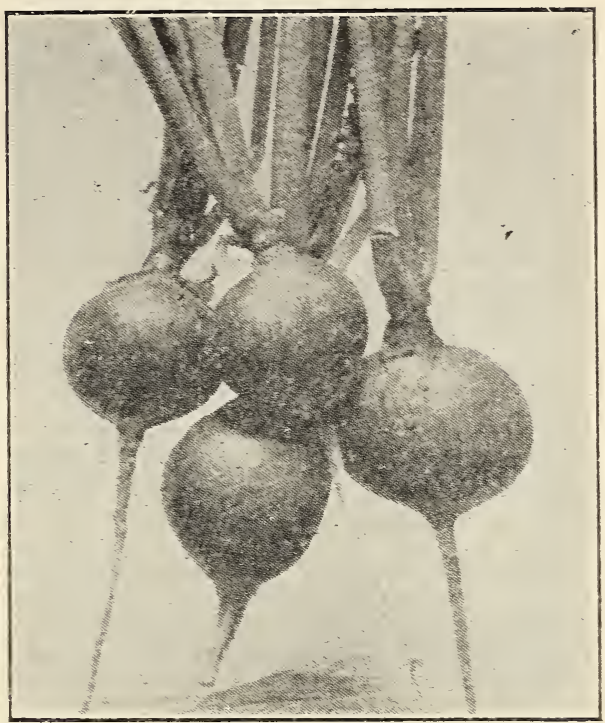

Rapid Red Radiah

remains in good condition while growing for a long time, thus allowing a continuous pulling from the same planting. Recommended for either spring or fall sowing. Try White Icicle.

Postpaid, pkt. $5 \mathrm{c}$; oz. $10 \mathrm{c}$; 1 ib. $30 \mathrm{c}$; lb. $\$ 1.00$.

\section{Rose China Winter (Scarlet China)}

The best of the winter sorts. Roots are cylin drical, or largest near the bottom, stump rooted or blunt at both ends; skin smooth and bright deep rose color: flesh white, crisp and pangent the roots grow 4 to 5 inches long and 2 inches thick. Sow in August and September.

Postpaid, pkt. $5 \mathrm{c}$; oz. $10 \mathrm{c}$; 1/4 lb. $30 \mathrm{c} ; \mathrm{lb} . \$ 1.00$.

\section{SALSIFY OR OYSTER PLANT}

CULTURE-Sow from March to July in sich, light, deeply-worked soil in rows 18 inches apart and thin out to 4 to 6 inches. Perfectly hardy and can remain out all winter. Fertilize with Sheep Manure or a good commercial fertilizer. Do not use coarse or fresh manure as it makes the roots ill-shaped and uneven. One ounce sows 50 feet of drill; 6 to 8 pounds to an acre. Cover seed $1 / 2$ inch deep.

MAMMOTH SANDWICH ISLAND-The best and most popular variety in cultivation, being far superior in size, weight and productiveness to any other. A strong grower, producing large, thick, tapering, almost white roots with little tendency to branch. One of the most desirable winter vegetables. The roots when cooked are rers palatable and nutritious and are served in a rar. iety of ways. The flavor is similar to ossters, and Salsify makes most ex. cellent soup. Postpaid Package $5 \mathrm{c} ; 0 \mathrm{z}$. 


\section{SPINACH SEED}

CULTURE-This is a very important crop in our market gardens, and is one of the most easily managed of all vegetables, requiring but little culture, and may be had fit for use the entire season. The main crop is sown in September, October and November, but for summer use it may be own at intervals of 2 or 3 weeks during $\mathrm{March}$ and April. The fall sowings should be covered when in exposed places, only with straw or litter during the winter to prevent freezing. Spinach is most tender and sweet when grown in rich soil; it finds a ready and profitable market. Two ounces sow $100 \mathrm{ft}$. of drill; 12 to $15 \mathrm{lbs}$. per acre in drills 18 to 24 inches apart. Cover seed one inch deep.

\section{Bloomsdale or Norfolk Savoy}

This very early and hardy variety is the popular favorite of the market and home gardener. The plant grows upright, the crumpled leaves are medium in size, and of beautiful dark green color, crisp and tender. In extremely hot weather it has a tendency to go to seed, but for early spring and fall planting it has no superior. Postpaid, pkt., 5c ; oz., $10 \mathrm{c}$; 2 oz., $15 \mathrm{c}$; $1 / 4$ lb., $20 \mathrm{c}$; lb., 50c.

\section{King of Denmark}

The best long season spinach, remaining two weeks longer than any other before bolting to seed. Plant vigorous and spreading; leaves large, rounded, crumpled and blistered: deep green in color. A good variety to follow Bloomsdale for spring sowing. This new variety is a very valuable addition to the Spinach family. Postpaid, pkt., 5c ; oz., 10c ; 2 oz., 15c ; 1/4 lb., 20c ; lb., 50c

\section{New Zealand}

Entirely distinct from the true Spinach. Plant tall and spreading with numerous side shoots; leaves medium green, rather small and pointed; grows well in hot weather and under adverse conditions. Only the leaves are used for greens which are produced profusely all summer, but are killed at first frost. Sow fairly early in the pring, after soaking the seed in lukewarm water for several hours. Plant 3 or 4 seeds in hills 2 feet apart each way. Postpaid, pkt., $5 \mathrm{c}$; oz., 10c ; $1 / 4$ lb., $30 \mathrm{c}$; lb., $85 \mathrm{c}$.

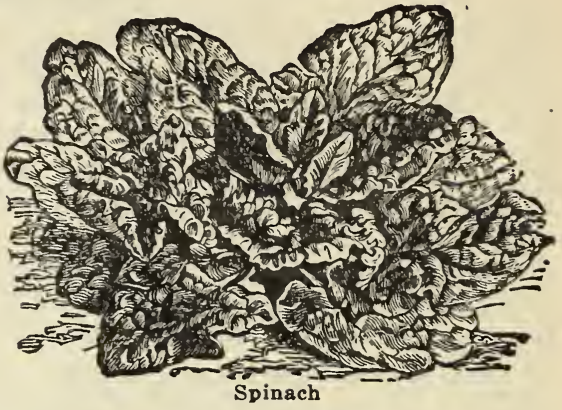

\section{SQUASH}

CULTURE-Squash is a quick growing vegetable and does best in sandy loam. It is strictly a hot weather plant and should not be planted until all danger of cool temperature is past. May and June are the principal squash planting months. After frost is past, plant in a warm. well pulverized, rich soil, 8 or 10 seeds in the hill, about 1 inch deep, the bush varieties 3 to 1 feet apart, the running sorts 8 to 10 feet. When well grown thin out, leaving three of the strongest plants in each hill. Apply Slug Shot or Arsenate of Lead to keep off bugs. Bush sorts, 1 ounce to 25 hills : 4 to 5 pounds to an acre. Running sorts 1 ounce to 10 hills; 3 to 4 pounds to an acre.

EARLY WHITE BUSH SCALLOP OR WHITE PATTY PAN - A very early summer squash; fruit flattened and scalloped, about 8 inches in diameter, comparatively smooth on the surface and sreamy white in color. Posptpaid, pkt., 5c ; oz., $10 \mathrm{c}$; $1 / 4 \mathrm{lb}$., $30 \mathrm{c}$; lb., $\$ 1.00$.

EARLY YELLOW BUSH SCALLOP OR YEL LOW PATTY PAN-Quite identical with White Bush, except in color which is deep orange and for this reason preferred by many.

Postpaid, pkt. $5 \mathrm{c}$; oz. $10 \mathrm{c}$; $1 / 4$ lb., $30 \mathrm{c}$; lb. $\$ 1.00$.

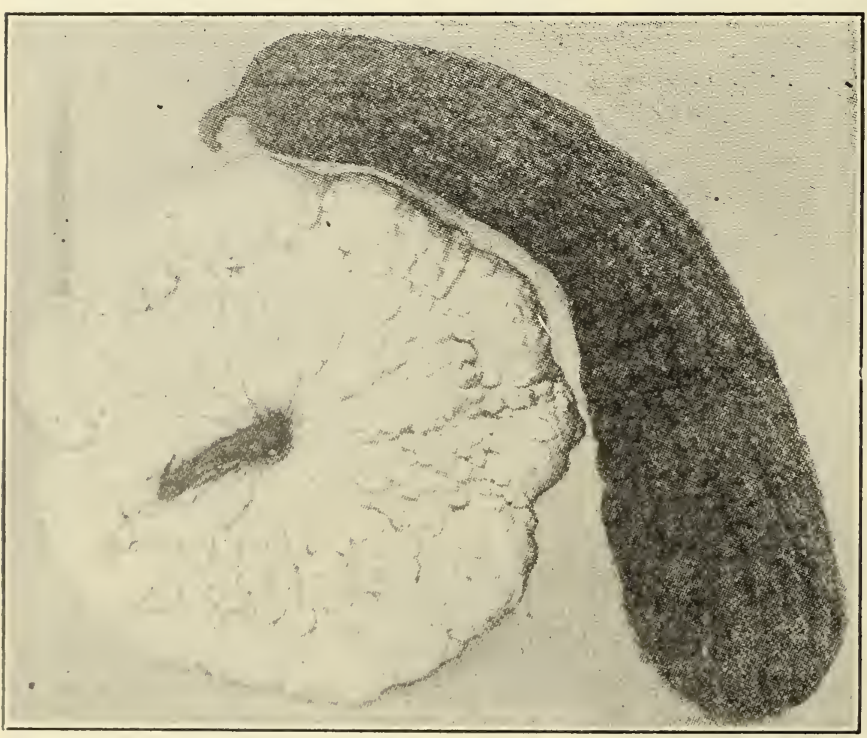

White Bush Scallop and Giant Summer Crookneck
GIANT S U M M E CROOKNECK (Bush) The largest and one of the earliest summer varieties, fruit often 2 to $21 / 2$ feet long, very warty and deep orange in color. Size, appear ance and fine qualities have contributed to the popularity of thi : squash. Postpaid pkt. $5 \mathrm{c}$; oz. $10 \mathrm{c} ; 1 / 4 \mathrm{lb} .30 \mathrm{c}$ lb. $\$ 1.00$.

I U B B A R D, IMPROVED (Running) The standard winter heavy and moderately warted; shell dark bronze green, showing more or less light green markings towards the blossom end. Flesh is bright orange-yellow, fine grained, thick and dry. Be ing handsome in appearance, a fine table rerotable and a good keeper. Hubbard, Improved is a splendid addition to the fall and winter gar den. Postpaid, pkt. 50 : oz. $10 \mathrm{c} ; 1 / 4$ lb. $30 \mathrm{c}$; lb. $\$ 1.00$. 


\section{TOMATO SEED}

CULTURE-For early use, sow in February or March, in a hot-bed or in boxes which should be placed near a window. When the seedlings are about 2 inches high, transplant in $2 \frac{1}{2}$ or 3 inch pots, or in rows 4 to 5 inches apart, keeping the temperature at about 60 degrees. Subsequent transplanting will make the plants stocky and strong. Do not set them in the open ground until all danger from frost is past. Then plant into a warm, sunny location, $3 \mathrm{ft}$. apart each way, and water freely until they are well established. One oz of seed will produce about 1500 plants; 5 oz. for an acre. Cover seed 1/4 inch.

SPARKS' EARLIANA-The earliest and best of the very early tomatoes. Fruit of fair size, round, very smooth and solid, and produced in clusters in center of the plant; color bright searlet. Very productive for an early sort.

Postpaid, pkt. 5c; oz. 25c; $1 / 4$ lb. 80 c; lb. $\$ 2.75$.

JUNE PINK-In habit of growth and productiveness it is identical with Earliana; it differs in being a large pink-fruited variety of spreading growth. The flesh is solid of fine texture, and slightly acid. Fruits flattened and somewhat ribbed. The best extra early purple or pink fruited variety.

Postpaid, pkt. $5 \mathrm{c}$; $1 / 2$ oz. 25c ; oz. $45 \mathrm{c}$; $1 / 4$ lb. $\$ 1.35$.

BONNY BEST-About a week earlier than Chalk's Jewel; fruit somewhat smaller but very smooth, solid and uniform, produced in clusters in center of the plant. Color bright red, ripening uniformly and is very productive. A good shipper, desirable color, an excellent tomato for any purpose.

Pestpaid, pkt. 5c; oz. $25 \mathrm{c} ; 1 / 4$ lb. $80 \mathrm{c}$; lb. \$2.75.

CHALK'S JEWEL-An exceptionally fine early variety, about two weeks later than Earliana. Fruit uniformly smooth, round and solid, color bright red. Very popular in this section on account of its productiveness and fine quality for so early a tomato.

Postpaid, pkt. $5 \mathrm{c}$; oz. $25 \mathrm{c}$; $1 / 4$ lb. $80 \mathrm{c}$; lb. $\$ 2.75$.
STONE-For many years Stone has been the standard main crop tomato and is more widely grown today than all other kinds. Nine-tenths of the tomatoes canned in the United States are Stone, and it is the best all-round variety for the home garden, trucker or canner. Stone is alwaye dependable, very vigorous and productive; fruits round, large, solid, smooth and deep red in color. Postpaid, pkt. $5 \mathrm{c}$; oz. $25 \mathrm{c} ; 1 / 4 \mathrm{lb}$. $80 \mathrm{c} ; \mathrm{lb}$. $\$ 2.75$.

MARGLOBE-Similar to the Livingston Globe only the fruit is red. It is resistant to nail-head rust and fusarium wilt. It is second early in maturity; the plants are medium large and erect. its foliage shading the fruit and preventing sun scald. Fruits are large, smooth and globular meaty and almost coreless. Very productive and well adapted for truck growing, shipping and canning.

Postpaid, plit. 5c; $1 / 2$ oz. $30 \mathrm{c}$; oz. $50 \mathrm{c}$; $1 / 4$ lb. $\$ 1.75$

PONDEROSA-An exceptionally large, purple fruited tomato and for home use one of the best: fruits very solid with few seeds and fairly smooth. Excellent for slicing and considered of finest quality, especially by those liking a tomato quite free from acid.

Postpaid, pkt. 5c; $1 / 2$ oz. $30 \mathrm{c}$; oz. 50c; $1 / 4$ lb. $\$ 1.75$.

BRIMMER-BEEFSTEAK OR TENDERLOIN - This splendid variety has the smooth and fine characteristics of the Stone and the size and fine qualities of the Ponderosa. The Brimmer in practicaliy all meat, being almost seedless. Fruits are purple in color, free from acid and are very attractive in taste and appearance. Postpaid, pkt. 5c; $1 / 2$ oz. $35 \mathrm{c} ;$ oz. $60 \mathrm{c}$; $1 / 4$ lb. $\$ 2.00$.

GOLDEN QUEEN or YELLOW TROPHYThe handsomest and best of all the yellow tomatoes. Highly esteemed for its deiicate flavor and meatiness. Ripens early, is large, smooth and solid. Color, golden yellow. Postpaid, pkt. 5c; $\mathrm{t} / 2$ oz., $25 \mathrm{c}$; oz., $40 \mathrm{c}$; $1 / 4$ lb., $\$ 1.25$.

TOMATO PLANTS-See page 22.

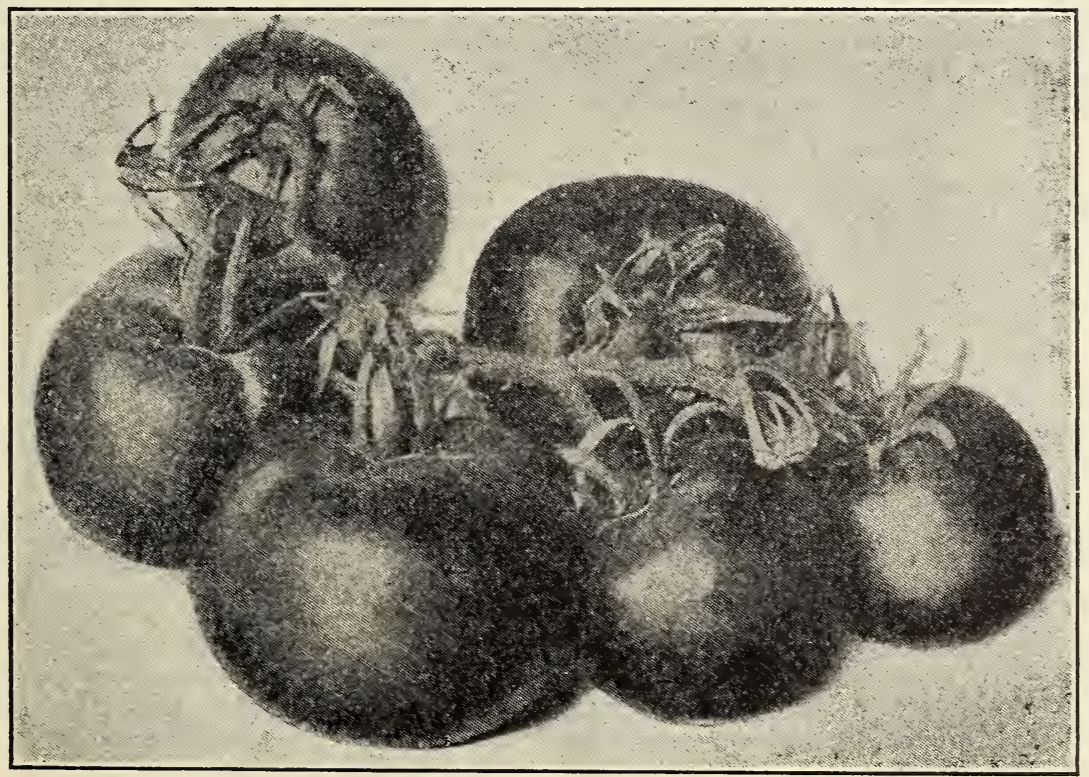




\section{TURNIP AND RUTA BAGA SEED}

CULTURE-Sow as early in the spring as possible so that the turnips may make their full size before hot weather. Purple Top Milan, Purple Top Strap Leaf and Purple Top White Globe are the best varieties for sprins planting. For fall or main crop, sow all the varieties listed below except Milan in July and August and Seven Top for salad as late as the last of September. Plant in rows $2 \mathrm{ft}$. apart, covering $1 / 2$ in. deep. When well started, thin out to about 4 inches apart in the row. Cultivate thoroughly and often. The Flea Beetle may be checked by spraying with Black Leaf " 40 " or Bordeaux Mixture. One oz. for $100 \mathrm{ft}$. of row; $2 \mathrm{lbs}$. per acre in rows.

TO KEEP FOR WINTER: Store Turnips and Ruta Bagas in a cool cellar and cover with sand, or they may be put into pits outside. Pile the turnips or Ruta Bagas on a well-drained situation, cover them with a few inches of straw and then sufficient earth to keep out frost.

\section{Extra Early Purple Top Milan}

At least a week earlier than any other turnip. Have small tops so that the rows can be planted close together. The roots are of medium size and flat, the flesh ivory white and the skin smooth. Unequaled for table use.

Postpaid, pkt., $5 \mathrm{c}$; oz., $10 \mathrm{c}$; $1 / 4$ lb., $20 \mathrm{c}$; lb. $65 \mathrm{c}$.

\section{Purple Top Flat Strap Leaf}

The most widely cultivated and best known variety; a very early, productive sort. Roots are flat, medium sized, purple or dark red above ground, white below, flesh white, tender and fine grained. Roots are in best condition for table use when about two and one-half inches in diameter but can be grown much larger for stock feeding. Postpaid, pkt. $5 \mathrm{c}$; oz. $10 \mathrm{c} ; 1 / 4$ lb. $20 \mathrm{c}$; lb. $65 \mathrm{c}$.

\section{Purple Top White Globe}

Almost a perfect globe in shape; flesh and skin white, colored purple or red above ground, very fine grained and sweet; a superior variety in eve ery way. This sort keeps well and is one of the best for market use. The roots when in best condition for table use are about two and onebalf inches in diameter, but can be grown much larger for stock feeding.

Postpaid, pkt. $5 \mathrm{c}$; oz. $10 \mathrm{c} ; 1 / 4 \mathrm{lb} .20 \mathrm{c} ; \mathrm{lb} .65 \mathrm{c}$.

\section{White Egg}

An early, oval or egg-shaped turnip, roots of medium size and smooth. Flesh frm and fine grained of snowy whiteness and very sweet. Particularly desirable for table use and can be sown as late as August. Can be planted in the spring as well as fall.

Postpaid, pkt. 5c; oz. 10c; $1 / 4$ lb. 20c; lb. 65c.

\section{Amber or Yellow Globe}

The best of the yellow-fleshed sorts. Roots globular and of large size; skin is clear yellow which is tinged green; flesh is light yellow fine grained and sweet. This variety keeps well and is a good cropper. A good table turnip when young and very valuable for stock feeding when full grown.

Postpaid, pkt. $5 \mathrm{c}$; oz. $10 \mathrm{c} ; 1 / 4$ lb. $20 \mathrm{c}$; lb. $65 \mathrm{c}$.

\section{SALAD TURNIP}

SEVEN TOP-Does not produce a good root but is a very hardy variety grown exelusively for the tops, which are used for greens. The most popular turnip in this section, grown for spring and winter salad. Sow early in the spring and as late as the last of September using 8 lbs. to the acre broadcast.

Postpaid, pkt. 5c; oz. $10 \mathrm{c}$; $1 / 4$ lb. $20 \mathrm{c} ; 1 \mathrm{~b} .65 \mathrm{c}$.

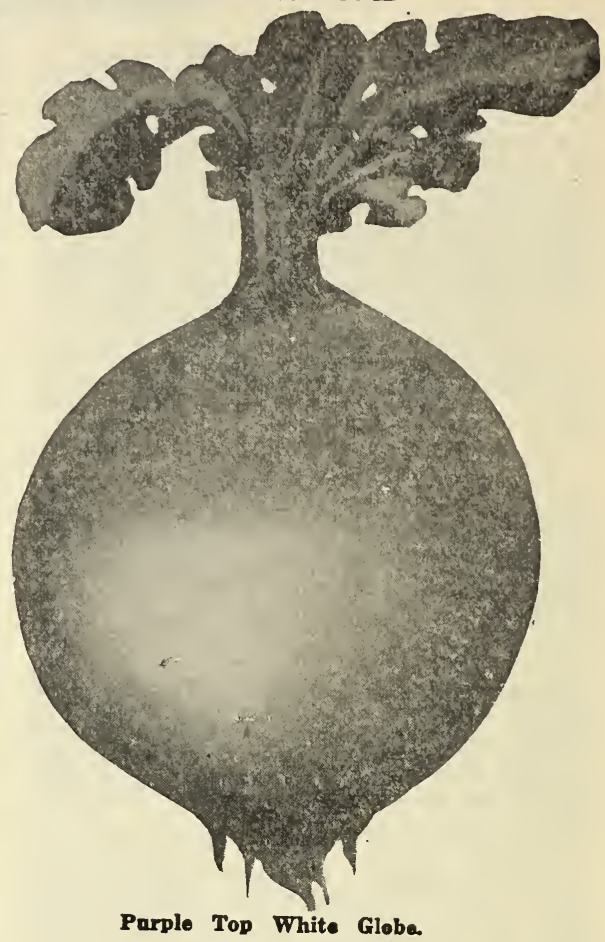

RUTA BAGA

The uses and value of the Ruta Baga are much the same as those of the Turnip. The Ruta Baga as a class have firmer flesh than Turnips but require a longer season for maturing and usually are more esteemed for winter use, while Turnips are better adapted for the early market. Under most conditions of growth Ruta Baga roots not so smooth on the surface nor as symmetrical in shape as Turnips but yield heavily, are superior keepers and are more highly prized for stock feeding.

IMPROVED AMERICAN PURPLE TOP (Long Island)-A hardy, productive variety with small neck; roots are large, oblong or globular in form with a very small tap root; color bright yellow with a purple top; flesh very solid, tender and sweet.

Postpaid pkt. $5 \mathrm{c}$; oz. $10 \mathrm{c} ; 1 / 4$ lb. $20 \mathrm{c}$; lb. $65 \mathrm{c}$.

\section{TOBACCO SEED}

One oz. will sow a bed of 50 sq. yards. The seed should be sown as early as possible after danger of frost is over. When the plants are about 6 inches high, transplant into rows 4 or $5 \mathrm{ft}$. apart each way, Use 8-4-4 Tobacco Fertilizer.

IMPROVED LARGE WHITE BURLEY-One of the best strains of burley tobacco. The stalks are large and strong, holding the leaves up out of the dirt. The leaves are large, broad, long and tapering, with white midribs, of very fine texture. Easy to cure and makes a heavy yield of rich bright leaf.

Postpaid, pkt., 10c; oz., 50c ; $1 / 4$ lb., $\$ 1.75$

JUDY'S PRIDE-An excellent strain of BURLEY tobacco, producing a bright leaf of high quality. The leaf is broad, long and tapering, with prominent white ribs. The stalk is strong and holds the leaves well up off the ground.

Postpaid, pkt. $10 \mathrm{c}$; oz. $60 \mathrm{c} ; 1 / 4 \mathrm{lb}$. $\$ 2.00$. 


\section{HARDY GARDEN IRIS}

Iris are the most effective if planted 3 of a kind in a clump. They are of easiest culture, blooming freely in any average soil. They are perfectly hardy and present a beautiful sight when in full bloom. The flowers are borne on long, strong stems above the foliage. They make good cut-flowers, lasting a long time in water.

CLARENCE WEDGE-Smoky purple.

FAIRY-White with blue border.

FLAVASCENS-Pale lemon sellow.

GRACCUS-Yellow with purple falls.

HONORABILIS-Golden yellow, falls a rich mahogany brown.

JUNIATA-Clear blue.

KRARPUT-Lavender with purple falls.

LEONIDAS-Plum color.

MIME CHEREAU-Pure white with a broad and

irregular border of clear blue.

OPERA-Reddish lilac, falls violet.

OTHELLO-Dark blue.

PURPLE KING-Rich red purple.

QUAKER LADY-Lavender, blue and gold.

WHITE KNIGHT-Snow white.

Postpaid, $25 \mathrm{c}$ each; 3 for $60 \mathrm{c}$; doz. $\$ 2.00$.

Not prepaid, $20 \mathrm{c}$ each; 3 for $50 \mathrm{c}$; doz. $\$ 1.80$.

\section{PEONIES}

Their requirements are very simple-a good, rich deep soil, and an open, sunny position; and a liberal supply of water during their growing season being sufficient to give an abundance and wealth of flowers, which rival the finest Roses in coloring and fragrance, and produce during their flowering season gorgeous effect not equalled by any other flower. The roots should be placed so that the crowns are covered with 2 inches of soil. Plant in spring as soon as frost is out of the ground, may also be planted in the fall. Fertilize with Vigoro or with Sheep Manure and Bone Meal.

We have large clumps in the following colors: red, pink, and white, of double Peonies.

Postpaid, each $45 \mathrm{c} ; 3$ for $\$ 1.15$.

\section{HYBRID-TEA ROSES}

RADIANCE-An ideal bedding Rose of American origin that continues to produce its large flowers throughout the most unfavorable hot sum. mer weather, when frequently many other varieties fail ; in color a brilliant carmine-pink, with salmon-pink and yellow shadings at the base of the petals; truly a Rose for every garden.

RED RADIANCE-A counterpart of Radiance from which it is a "sport" possessing all the good traits of that valuable variety, but differing in color which is a bright cerise-red.

\section{BY EXPRESS ONLY}

Not prepaid 65c each; 5 for $\$ 3.00 ; 10$ for $\$ 5.50$. Ask for prices in larger quantities.

\section{ROSE SPRAYS}

\section{Aphistrogen}

makes a complete spray for aphis and most sucking insects; prepared especially for roses and other plants. Mix one tablespoonful to quart of water ; 2 ozs. to the gallon.

Postpaid, 2 oz. bottle $60 \mathrm{c}$; $1 / 2$ pt. can $\$ 1.35$.

Not prepaid, 2 oz. bottle $50 \mathrm{c} ; 1 / 2$ lb. can $\$ 1.35$.

\section{unotrogen} a highly concentrated form of fungicide that will control mildew and black spot on roses. Will not discolor the foliage. Mix one tablespoonful to quart of water, 2 ozs. to the gal. Cannot be mailed. Not prepaid $1 / 2$ pt. $75 \mathrm{c}$; pt. $\$ 1.25$; quart $\$ 2.00$.

\section{Insectrogen} amplete spray for leaf shewing insects, including caterpillars, rose slug worms and Japanese Beetles. Mix one tablespoonful to quart of water 2 ozs. to the gallon. Cannot be mailed.

Not prepaid, 4 ozs. $60 \mathrm{c} ; 1 / 2$ pt. $\$ 1.00$; qt. $\$ 1.75$.
HARDY PERENNIAL PHLOX

Among hardy perennial plants no class is of more importance than the Phloxes, succeeding in almost any soil and position; and flowering through a long season; and while they will continue in good conditions and flower freely for many years without attention, yet they respond quickly to and are improved by liberal cultivation. We list only tall varieties.

ELIZABETH CAMPBELL-Bright salmon pink with lighter shadings and dark red eye; one of the handsomest and most attractive.

MRS. LINGARD-Longest spikes of any Phlox -blooms from the ground up; the earliest blooming, sweetly fragrant. Pure white, with small lavender eye.

MRS. JENKINS-A very free flowering early variety producing panicles of pure white flowers.

RHEINLANDER-A new variety of great beauty, a rare shade of salmon-pink intensified by a distinct claret-red eye. Flowers and truss of unusual size.

RYNSTROM-Bright- rose-pink flowers, combining into heavy, massive flower trusses, carried on strong stems.

THOR-A splendid new variety of a lively shade of deep salmon-pink suffused and overlaid with a scarlet glow. Very popular.

WIDAR - Light rosy violet with a white center, strong plants bearing magnificent trusses of large flowers.

Postpaid, 35c each; 3 for $75 \mathrm{c} ; 6$ for $\$ 1.40$; Not prepaid, $25 \mathrm{c}$ each; 3 for $65 \mathrm{c} ; 6$ for $\$ 1.25$;

PHLOX AMOENA-A useful variety for carpeting the ground, the rockery, or the border: it grows but 4 inches high and in spring is a sheet of rich pink flowers.

PHLOX DIAVANCATA CANADENSIS-One of our native species, which is worthy of extensive planting. Commencing to bloom early in April, and continuing through May, with large, fragrant lavender flowers on stems 10 inches high.

PHLOX SUBLATA ROSEA-Bright rose pink variety of creeping phlox or "Moss Pink." An early spring flowering type, with pretty moss-like evergreen foliage, which, during the flowering season, is hidden under the masses of bloom. An excellent plant for the rockery, or the border, and invaluable for carpeting the ground or covering graves.

Postpaid, 35c each; 3 for $85 \mathrm{c}$; 6 for $\$ 1.50$;

Not prepaid, $25 \mathrm{c}$ each; 3 for $75 \mathrm{c} ; 6$ for $\$ 1.35$;

\section{HARDY LILIES}

LILIUM AURATUM-(The Gold-Banded Lily of Japan). One of the finest and most popular hardy garden lillies. Flowers white, dotted crimson, with a clear golden band running through the center of each petal; very fragrant. A splendid lily for pots or for planting out in the shrub or plant border. The flowers are large. It is perfectly hardy with ordinary protection and suitable soil. Postpaid, $45 \mathrm{c}$ each; 3 for $\$ 1.15$; doz. $\$ 4.00$.

LILIUM REGALE-the REGALE LILY is generally considered the most beautiful of all lillies. Flowers are white suffused with pink and with a beautiful shade of canary-yellow towards the center. The fragrance is fascinating. Blooms in July. Plant 6 inches deep on a little sand for drainage. Postpaid, $35 \mathrm{c}$ each; 3 for $85 \mathrm{c}$; doz. $\$ 3.00$

LILIUM RUBRUM-This is the most popular and satisfactory of the Speciosum Lilies. It does equally well in open border or in pots. When fully open, the petals curve gracefully on the flower stem, exposing the beautiful markings. It is a white lily, spotted and rayed rosy red. Postpaid, $45 \mathrm{c}$ each; 3 for $\$ 1.15$; doz. $\$ 4.00$.

LILIUM TIGRINUM-(Tiger Lily). This lily, which is widely cultivated in this country, and looked upon as a native, originally came from China and Japan. The flowers are orange, spotted purple, opening in August and September on 2-4 foot stems.

Postpaid, $30 \mathrm{c}$ each; 3 for $65 \mathrm{c}$; doz. $\$ 2.40$. 


\section{DAHLIA AND OTHER BULBS}

Dahlias require plenty of room and thorough cultivation. Plant bulbs 4 inches deep, mixing $1 \mathrm{lb}$. of bone meal or 2 level tablespoonfuls of Vigoro in the hole in which the root is to be planted and mix thoroughly with the soil. Water regularly at least once a week in dry weather. Plant after danger of frost is past and as late as the first of June.

\section{Dahlias}

BALLET GIRL (Cactus) - A very large flower with long very finely quilled petals. Color, orange tipped white; some flowers solid orange on same plant.

Postpaid, 80c each; 3 for $\$ 2.25$.

EMMA MARIE (Cactus) - Color deep rose, tinting to cream at center. Flowers large, with full high centers, and borne erect on cane stiff stems. An early and free bloomer. Postpaid $75 \mathrm{c}$ each; 3 for $\$ 2.00$.

MAE GREFE (Cactus) - The largest pink cactus in existence. It is a strong, vigorous grower and free bloomer. Color pure pink, shading to rose pink, tinting lighter at center and tips of petals. 5 feet tall.

Postpaid $75 \mathrm{c}$ each; 3 for $\$ 2.00$.

GOLDEN WEST (Cactus)-Rich golden bronzy yellow, with scarlet shading at the center and base of the petals. The best bronze cactus for garden and cut flowers.

Postpaid 50c each; 3 for $\$ 1.35$.

SOPHY MOREY (CACTUS)-A giant Cactus that is ideal in every way ; large size, full form, long stiff stems, delicately beautiful color, good keeper, vigorous grower and profuse bloomer. Color white, lightly suffused and overlaid phlox purple. 4 feet tall.

Pastpaid 50c each; 3 for $\$ 1.35$.

SUNSET GLOW (CACTUS)-A very profuse bloomer, fine for garden and cut flowers. A splendid exhibition variety. Very early bloomer; flower carried on splendid stem 3 to 4 feet tall. The color is yellow at base of petal, outer part overlaid flame scarlet, tipped yellow.

Postpaid 40c each; 3 for $\$ 1.00$

MILLIONAIRE (Decorative)-Flowers are of gigantic size and of unusual depth; color a pleasing shade of lavender with a faint pink cast over-shading it.

Postpaid 75c each; 3 for $\$ 2.00$.

PORTHOS (Decorative)-The nearest to blue dahlia yet produced. A beautiful formed lavender blue of medium size, produced on long stiff wiry stems. Should be planted to get partial shade in middle of the day, as it is susceptible to the

Postpaid $75 \mathrm{c}$ each; 3 for $\$ 2.00$.

JERSEY BEAUTY (Decorative)-A famous prize winning variety; blooms are carried high above the foliage on long, strong stems; flowers are of immense size and of a vivid glowing pink color; a wonderful keeper when cut.

Postpaid 50c each; 3 for $\$ 1.35$.

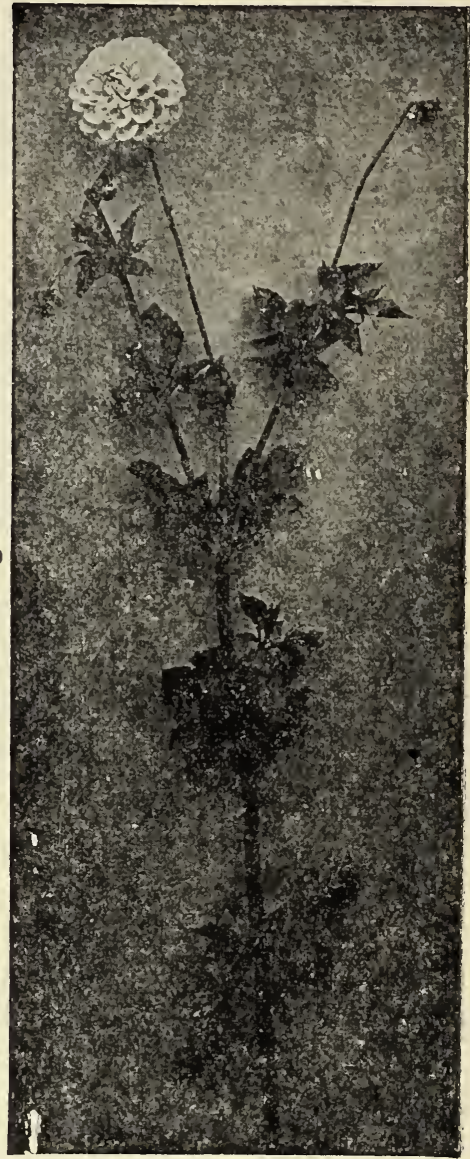

Ball or Show Dahlia
MRS. I. de ver WARNER (Decorative)-Large perfect flowers of charming color; a deep mauvepink on stout stems. A good grower and free bloomer. Can be grown to a diameter of 11 inches One of the best dahlias in cultivation.

Postpaid, 40c each; 3 for $\$ 1.00$.

MINA BURGLE (Decorative)-Considered the best red decorative dahlia, being a rich cardinal red. The plant is a strong, vigorous grower, producing flowers freely on long stiff stems.

Postpaid, 35c each; 3 for $85 \mathrm{c}$.

ETHEL MAULE (Show or Ball)-Pure white, slightly tinged pale lavender in the center. Flowers of large size and fine form.

Postpaid 50c each; 3 for $\$ 1.35$.

MAUD ADAMS (Show or Ball)-One of the most delicately lovely of all ball dahlias, being a clear shell pink. It is beautifully formed and an early bloomer, on fine stiff stem.

Postpaid 35c each; 3 for 85 .
RED DUKE (Show or Ball)-Rich dazzling cardinal red; splendid form with quilled petals.

Postpaid 35c each; 3 for $85 \mathrm{c}$.

ELEGANTA (Pompon) - A favorite variety with lovely deep pink blooms. The flowers are borne profusely and are fine for garden display and for cutting.

Postpaid 50c each; 3 for $\$ 1.35$.

RED BOY (Pompon)-A beautiful deep red pompon dahlia of fine form.

Postpaid 50c each; 3 for $\$ 1.35$.

SNOWCLAD (Pompon)-A pure white pompon dahlia of perfect form, early profuse and continuous bloomer. Petals of an exquisite texture.

Postpaid $35 \mathrm{c}$ each; 3 for $85 \mathrm{c}$.

\section{Hardy Chrysanthemums}

These are universally popular for outdoor bedding in the spring. They produce a lavish profusion of b'ooms. They are quite hardy if planted in a well-drained position, and, require only a slight covering of leaves or litter during the winter.

Pink, White, Red, Yellow. Postpaid, 40c each = 3 for $\$ 1.00$; $\$ 3.00$ per doz. 


\section{SUMMER FLOWERING BULBS AND ROOTS}

\section{Gladioli}

Attractive and easily grown summer bloomers, giving gorgeous effects in mixed beds, massed in large clumps, and when planted in clusters among shrubs. For a succession, plant at intervals from April till June. Plant 6 inches apart and 2 to 3 inches deep.

Mix sheep manure or vigoro with the dirt in each hill when planting.

ALICE TIPLADY - A splendid variety of the primulinus type. The flowers are large. Color a beautiful orange saffron. A very popular cut flower

CHICAGO WHITE-The very best early white with lavender markings in the troat; early blooming and one of the leading varieties for cut flowers.

LE MARECHAL FOCH-One of the most wonderful novelties; flowers of immense size, well opened and beautifully ruffled. Color, salmonpink, flaked and striped deeper at edges of petals.

MAIDEN'S BLUSH-Enchantress pink flowers of finest form on stiff slender stems. The most beautiful pink of the primulinus type.

MRS. FRANCIS KING-A rich salmon-red spotted with carmine. Flowers are carried on long, artistic spikes. A splendid cut flower and excellent keeper.

MRS. FRANK PENDLETON-The flowers are of largest size, borne on strong straight spikes. In color a lovely salmon-pink with brilliant deep red blotches in the throat. A color combination rivaling many of the finest Orchids in its richness.

ROSE 1910-Pure deep rose pink, with white center lines on lower petals. Extra large flower.

SCHWABEN-A most meritorious variety of wonderful vigor, with strong erect spikes and large well expanded flowers of a clear canary yellow with a small blotch of deep garnet in the throat.

Postpaid 3 for $30 \mathrm{c}$; $1 / 2$ doz. $55 \mathrm{c}$; doz. $\$ 1.00$

EVELYN KIRTLAND-Flowers of strong substance; color a beautiful shade of rosy nink, darker at the edge, fading to shell-pink at the center with brilliant scarlet blotches. Very beautiful.

LOUISE-Richest lavender. Large wide blooms, marked rich, royal purple. Nothing more beautiful.

MRS. DR. NORTON-Color is delicate pink, shading to rose at tips of pointed petals, yellow throat. Outside of flower rose a blend of wonderful tints, borne on long spikes.

-..VIRGINIA or SCARLET PRINCEPS-A beautiful soft raspberry red, begonia red in the throat. Makes a gorgeous display.

WAR-The finest of its color yet introduced. Flowers often measure 7 inches across. Color deep ox-blood red shaded crimson black.

Postpaid 3 for $35 \mathrm{c}$; $1 / 2$ doz. $65 \mathrm{c}$; doz. $\$ 1.25$.

GLADIOLI IN MIXTURE-Composed of high grade varieties and embracing a wide range of colors in a well balanced mixture.

Postpaid, 3 for $20 \mathrm{c}$; $1 / 2$ doz. $35 \mathrm{c}$; doz. $60 \mathrm{c}$; 100 for $\$ 4.00$.

\section{Lily of The Valley}

The Lily of the Valley is one of the best known and appreciated of all flowers. After once beins planted in a suitable place they will produce their graceful and sweet scented blooms every spring for an indefinite time. They do best in shady, moist place and should be fertilized well with pulverized Sheep Manure or with Vigoro. The roots can also be taken up and planted in pots for indoor blooming.

Postpaid, doz. $\$ 1.00 ; 50$ for $\$ 4.00 ; 100$ for $\$ 7.50$.

\section{Selected Cannas}

One of the best of all summering flower plants both for flowers and foilage for use in borders or beds. The flower spikes are of enormous size and most brilliant colors which continue to bloom from early summer until cut by frost. Plant in April and May when frost is out of the ground, deeply about $1 \frac{1 / 2}{2}$ feet apart and fertilize with Vigoro or Sheep Manure.

GLADIATOR-A very popular variety with al Canna lovers. It is a sturdy robust grower, 436 feet tall. The flowers are of immense size and showy color. The blooms are rich yellow, at tractively marked with bright crimson. The fo liage is green.

KING HUMBERT-This enormous flowering Canna is of a bright orange scarlet with bright red markings. It grows from 4 to 5 feet tall and has very large leaves, which are of a rich coppery bronze. This is a robust grower, succeeding almost anywhere and is the most popular of all bronze leaf Cannas.

MRS. ALFRED F. CONRAD-The large exquisite shaded salmon pink flowers are produced in abundance on robust, upright growing plants about 4 feet tall. The foliage is green.

STATUE OF LIBERTY-A very tall growing canna, height about 7 feet. The orchid type, blazing, flame-red flowers are immense. The foliage is of a rich, luxuriant bronzy shade. The leaves are larger than any other canna.

Postpaid, each 15c; 3 for $40 \mathrm{c}$; $1 / 2$ doz. $70 \mathrm{c}$; doz. $\$ 1.35$.

\section{Tuberose Bulbs}

This is one of the most fragrant flowers in cultivation and has a wide range of uses. It will make a good pot plant, can be bedded for cut flowers, or will make an ideal border plant. They are easy to grow and very popular with both florists and home gardeners. Plant outdoors in spring when ground is warm.

DOUBLE DWARF EXCELSIOR PEARL-This is the most popular variety. The flower spikes are about three feet tall and fully covered with fragrant double blossoms.

Postpaid, $1 / 2$ doz. $35 \mathrm{c}$; doz. $60 \mathrm{c}$

\section{Caladium Esculentum}

\section{(Elephant's Ear)}

One of the most effective plants in cultivation for beds, borders, or for planting out upon the lawn; they are used extensively in public parks where their decorative value is greatly appreciated. To obtain the best results should be planted where they will obtain plenty of water and an abundance of rich compost. When full size they stand six to ten feet high, and bear immense light green leaves, three to four feet long by two and one half wide. Plant when ground becomes warm, covering 3 inches deep.

First Size Bulbs-11-13 inches in circumference. Postpaid, $30 \mathrm{c}$ each; 3 for $85 \mathrm{c}$; doz. $\$ 3.25$.

Second Size Bulbs-9 to 11 inches in circumference. Postpaid, 20c each; 3 for $50 \mathrm{c}$; doz. $\$ 1.75$. 


\section{SELECTED FLOWER SEED}

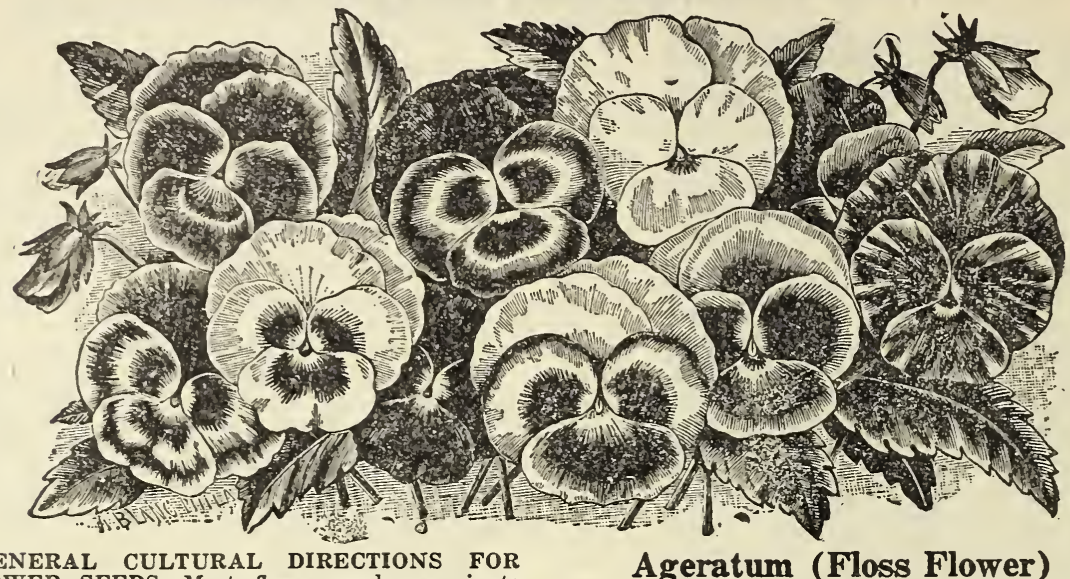

GENERAI CULTURAL DIRECTIONS FOR FLOWER SEEDS-Most flower seeds germinate in a rather light sandy loam, exposed to the sun, while a few are benefitted by partial shade. Nearly all hardy seeds vegetate better when planted in early spring as soon as the soil can be worked easily and has become warm.

A general rule for the seed-bed is to have the soil rich, level, and worked finely. Sow the seed evenly in the rows, cover with the finest of soil, about three times the diameter of the seed, and press the soil firmly over the seed. The soil should never become dry after the seeds have swelled; if it does, they will be sure to fail.

After the seeds are up, care must be taken to give them plenty of air and moisture, and yet not too much water, or they will "damp-off" (rot at the top of the ground). When transplanted to the bed or border, water frequently.

Flower seeds are sent postpaid at prices quoted.

PULVERIZED SHEEP MANURE-Is one of best fertilizers to use outdoors.

STIM-U-PLANT-An oderless plant food having a high percentage of nitrogen and phosphoric acid, is well adapted for use in doors.

VIGORO-Releases plant food in the soil and may be used to advantage in the flower bed or for potted plants.

\section{Alyssum (Sweet Alyssum)}

A free-flowering annual of quick, low growing habit producing white flowers which begin to bloom early in the spring, continuing throughout the season. Sweet Alyssum is an excellent border plant, as it is of close, compact habit and uniform in height. It is also desirable for hanging baskets or vases, trailing over the sides and producing a profusion of fragrant blooms. It does well in almost any kind of soil and is used extensively in rock gardens or for pot culture. Prefers a sunny location and a soil which has good drainage.

Sow the seed thinly early in the spring in shallow drills where the plants are to stand, covering thinly with fine soil. Thin the young plants to stand 4 inches apart. Height 4 to 8 inches.

Pkt. $10 \mathrm{c} ; 1 / 2$ oz. $25 \mathrm{c} ;$ oz. $40 \mathrm{c}$.

\section{Amaranthus}

LOVE LIES BLEEDING-Brilliant folfaged annuals growing 3 to 5 feet high, bearing long, drooping crimson flower spikes. Useful in borders of tall plants or for the center of large beds. They thrive best in a hot sunny location, not too rich soil and should be given sufficient room to develop their full beauty. Sow seed one eighth inch deep in open ground after all danger of cold is past or start indoors to set out later. Transplant to stand 2 to 3 feet apart.

Pkt. $10 \mathrm{c} ; 1 / 4$ oz. $30 \mathrm{c}$; $1 / \mathrm{g}$ oz. $50 \mathrm{c}$.
One of the best bedding hardy annuals produc ing a sheet of bloom from early summer till frost. Unlike many bedding plants, their flowers are not liable to be spoiled by rain, nor does the color fade out. Easily raised from seed, which is usually started in a hotbed or window box and transplated to the open ground in May. Can also be sown outdoors in May. Barely cover the seed and thin to stand about 12 inches apart. Can be grown as pot plants for fall and winter blooming.

MEXICANUM, BLUE-A fine branching variety, growing two feet tall, covered all summer and fall with clusters of azure blue flowers. 3 to 4 inches in diameter.

Pkt $10 \mathrm{c} ; 1 / 8$ oz. $20 \mathrm{c} ; 1 / 4$ oz. $35 \mathrm{c} ; 1 / 2$ oz. $55 \mathrm{c}$.

\section{Asters}

Are one of the most popular hardy annuals valuable alike for garden decoration or cutting.

In early spring sow in cold frames or in pots and boxes in the house, covering the seed with about $1 / 4$ inch of good soil. When the plants are strong enough, transplant about 12 inches apart in deeply dug, well prepared beds in sunny locstions. Can be sown in the open ground in May.

QUEEN OF THE MARKET-Very valuable for bedding and cutting, as they grow about 15 inches tall and they are the first asters to bloom. Measuring 3 to 4 inches in diameter.

Mixed colors, pkt. $10 \mathrm{c} ; 1 / 8$ oz. $25 \mathrm{c} ; 1 / 4$ oz. $45 \mathrm{c}$.

GIANT CREGO-This mid-season variety is one of the prettiest types. The flowers are of immense size, measuring 4 to 5 inches in diameter. They are fully double and the long graceful petals are most attractively curled and twisted, the flowers resembling Chrysanthemums. They are fine for cutting as they are borne on long strong stems, the plants growing from 2 to $21 \%$ feet tall. Sometimes called Ostrich Plume.

Mixed colors, pkt. $10 \mathrm{c} ; 1 / 8$ oz. $25 \mathrm{c} ; 1 / 4 \mathrm{oz}$. $45 \mathrm{c}$.

AMERICAN LATE BRANCHING-This variety blooms profusely during the late fall months, following the Crego Asters. The flowers are of enormous size and are exceptionally fine for cutting on account of the long stems. They grow from 2 to 3 feet tall. We offer the following colors: Pink, White, Rose, Lavender, also Mixed Colors. Pkt. $10 \mathrm{c}$; $1 / 8$ oz. $30 \mathrm{c}$; $1 / 4$ oz. $55 \mathrm{c}$.

AMERICAN BEAUTY ASTERS-These plants make a rounded bush $2 \frac{1}{2}$ to 3 feet tall, bearing immense flowers which measure 4 to 5 inches in diameter. These wonderful blooms are borne on strong stems, much longer and heavier than the earlier varieties. They start blooming after many other Asters have practically finished and will stand a great deal of heavy frost.

Mixed colors, pkt. $10 \mathrm{c} ; 1 / 8$ oz. $40 \mathrm{c} ; 1 / 4$ oz. $70 \mathrm{c}$. 


\section{SELECTED FLOWER SEED-Continued}

\section{Double Baby's Breath (Gypsophila Paniculata)}

A new double type of Gypsophila. A hardy perennial but will bloom the first year from early sown seed. The small double white flowers are borne most profusely. Attractive in the garden and very desirable for cutting. May be bunched with other flowers adding grace and lightness to any boquet. Height two to three feet. Sow the seed early where the plants are to bloom.

Pkt. $10 \mathrm{c}$; $1-16 \mathrm{oz}$. 50c; $\frac{1 / 8}{18} \mathrm{oz} .85 \mathrm{c}$.

\section{Bachelor's Button or Ragged Robin}

Centaurea or Dotible Cornflower are of the easiest culture and thrive well in any ordinary garden soil. They do best if sown as early in the spring as the ground can be worked into a fine loose condition. In a sunny and airy location they will bloom from June until frost. The plants grow 15 to 24 inches tall and make a fine show in the garden, besides producing excellent cut flowers. Cover seed about 1/4 inch deep, thin to 3 or 4 inches apart. Flowers should be kept picked so as to prevent plants exhausting themselves by seeding. It is a hardy annual and reseeds itself, the self sown seedlings appearing jear after year. DOUBLE BLUE-Pkt. 10c; 1/8 oz. $15 \mathrm{c} ; 1 / 4 \mathrm{oz}, 25 \mathrm{c}$.

\section{Balsam}

One of the oldest and best known summer blooming snnuals of easy culture. Desirable far garden or pot culture. Balsams need rich soil, hot sun, and plenty of water. Sow the seed half an inch deep in window boxes or hot beds early. or in the open ground in May, and transplant when two or three inches in height. Thin to stand 18 inches apart. The plants form symmetric, well branched, erect bushes, the branches being almost covered with the magnificent double flowers. Height 2 feet. Stimulate by weekly applications of liquid sheep manure. The delicate flowers of waxy texture are borne along the stems among the leaves.

MIXED DEFIANCE-A well balanced misture of all the best colors.

Pkt. $10 \mathrm{c} ; 1 / 4$ oz. $30 \mathrm{c} ; 1 / 2$ oz. $50 \mathrm{c}$.

\section{Begonias}

Few plants which can be grown so readily from seed will afford such a profusion and brilliancy of flowers as these tender perennials. Start the seed indoors any time during February, March, or April, and transplant to the open ground the middle of May. The seed is very fine and should be pressed into the ground without covering.

SPECIAL MIXTURE-This mixture comprises a wide range of shades of pink, red and white. Excellent for window boxes, pots, beds or borders.

Plt. $10 \mathrm{c}$; 1-64 oz. $35 \mathrm{c}$; $1-32$ oz. $55 \mathrm{c}$.

\section{Calendula-Pot Marigold}

A well-known, old-fashioned annual that has long been in favor; useful for borders and beds: and are now largely used by florists for cut flowers. They are of easy culture, succeeding in almost any soil and are in bloom from early summer till frost. Plants are one and one-half to two feet high. For the best results plant seed early indoors and transplant to place when danger from frost is past. Satisfactory results may also be obtained from sowings made out of doors sfter ground is warm and dry. Plants should be thinned to twelve inches apart in the row.

THE BALL-Extra double, bright orange, free flowering rariety.

Pkt. $10 \mathrm{c} ; 1 / 2$ oz. $50 \mathrm{c}$; oz. $85 \mathrm{c}$.

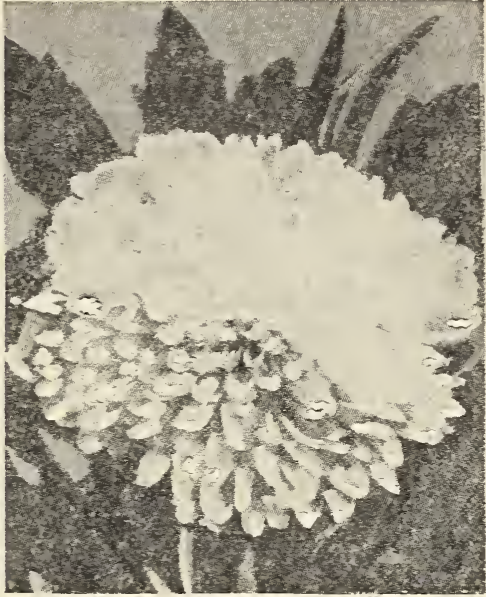

Aster

Calliopsis

A showy and beautiful free-flowering annual, of the easiest culture, doing well in any sunny position, blooming all summer, and excellent for cutting and massing. It is best to sow them where they are to bloom, corering seed $1 / 2$ inch deep, thin out to stand 2 feet apart. By keeping the old flowers cut off the flowering season can be lengthered until frost. Can be sown up to July 1st.

TALL MIXTURE-Contains a great number of large and small flowering varieties.

Pkt. $10 \mathrm{c} ; 1 / 4$ oz. $25 \mathrm{c} ; 1 / 2$ oz. $45 \mathrm{c}$.

\section{Candytuft}

A hardy dwarf annual of easiest culture, freeblooming, showy, and useful for beds, borders and edgings. Excellent for cut flowers. Height one foot. Sow seeds where plants are to bloom in rows 8 in. apart, thinning out to afford plenty of room, as they branch freely.

UMBELLATA MIXED-Pkt. 10c; $1 / 4$ oz. 25c.

\section{Canna Seed-Indian Shot}

Very showy tender perennials, having large tropical foliage surmounted by handsome spikes of blooms in many glowing colors. Fine plants can easily be raised from seed started in pots indoors during February in light sandy soil and set in the open during May. Soak seeds in lukewarm water until ther show evidence of swelling. Cover with 1/2 in. fine soil. Keep soil moist. The roots must be lifted in the fall and stored in dry soil in a cool but frost-proof place.

IMPROVED LARGE-FLOWERING, MIXEDSeed saved from the newest and best varieties, which will produce strong sturdy plants with arge flowers. Pkt. 10c; $1 / 2$ oz. $25 \mathrm{c} ;$ oz. $40 \mathrm{c}$

CANNA ROOTS are listed on page 29.

\section{Carnation}

These very popular farorites are valuable for culture in the open ground in summer and for pot culture in winter. Seeds of the Marguerite type somn in the spring, will, by August, prodace plants that will be full of bloom until frost takes them; or they may be cut back, potted, and carried over winter in a cool room. Especially desirable for bedding as an annual and for cut ting. Seed may be sown outdoors early in spring, using well pulverized soil, preferably sandy loam. Make rows one foot apart and cover seed with one-fourth inch of fine soil firmly pressed down. When two inches high, thin to twelve inches.

MARGUERITE-Extra early double mixed; 12 to 15 inches tall; pkt. $10 \mathrm{c}$; $1 / \mathrm{s}$ oz. $25 \mathrm{c}$; $1 / 1 \mathrm{oz}$. $40 \mathrm{c}$. 


\section{SELECTED FLOWER SEED-Continued}

\section{Chrysanthemums}

These are altogether different from the large flowered Chrysanthemums grown by florists. They are hardy annuals from Northern Africa. The foliage is a rich dark green, firmly cut and quite ornamental. The plants grow 12 to 13 inches high. Seeds should be sown thinly in shallow drills early in the spring. Thin out to 6 inches apart. A free flowering border plant valuable for cutting. They bloom profusely from July until October. For fall blooming sow in June.

CORONARIUM, DOUBLE MIIXED - Compact bushy growth, about 18 inches in height. The flowers are double, including a wide range of colors. Pkt. $10 \mathrm{c}$; $1 / 4$ oz. $25 \mathrm{c}$; $1 / 2$ oz. $40 \mathrm{c}$.

\section{Cockscomb}

Free-blooming annuals, growing best in rather light soil, not too rich; make grand border plants and are attractive for pots. Seed can be sown under cover in early spring and planted out in May, or may be sown out of doors in May. Thin to stand three feet apart. Plenty of moisture is important. Grows twelve inches tall and is valuable as a cut flower.

DWARF MIXED-A fine mixture of the best dwarf varieties. Pkt. $10 \mathrm{c} ; 1 / 80 \mathrm{oz} .40 \mathrm{c} ; 1 / 4 \mathrm{oz} .75 \mathrm{c}$.

\section{Coleus}

Magnificent ornamental foliage plants for house or garden culture. The leaves are of many shapes, and the shades and colors are of remarkable beauty. Sow in shallow pots in rich light soil. Cover the seed lightly with earth and keep the plants in an even moist temperature. Transplant to the open ground in bed or border as soon as danger of frost is over. For house plants seed may be sown indoors in the fall. Tender perennial plants about one to two feet high.

RAINBOW MIXTURE-This fine mixture contains a wonderful assortment of extra large leaved types of many colors. The plants are all of tall strong growing habit, and the leaves are exceptionally bright in color.

Pkt. $10 \mathrm{c} ; 1-32$ oz. $45 \mathrm{c} ; 1-16$ oz. $80 \mathrm{c}$.

\section{Columbine or Aquilegia}

Charming hardy plants, bearing in countless numbers through May and June exquisite clear, blue, white, rose, yellow, purple and striped blossoms. For planting in permanent borders or edges of shrubbery this old-fashioned favorite is one of the best. They thrive well with ordinary garden culture, but do best in partially shaded nooks. Few hardy perennials are so easily grown from seed. Will bloom first season if sown very early. Sow the seed, which is of rather slow germination, in open ground early in spring in any rich, well drained garden soil. In permanent bed plants should have at least one foot each way. Keep clear of weeds and give each year a dressing of well rotted manure or sheep fertilizer. Seed may also be sown outdoors in fall. Hardy herbaceous perennials; two to three feet high.

LONG SPURRED HYBRIDS-Make excellent cut flowers-Pkt. $10 \mathrm{c} ; 1-16 \mathrm{oz} .35 \mathrm{c} ; 1 / 8 \mathrm{oz} .60 \mathrm{c}$.

\section{Coreopsis or Perennial Calliopsis}

This is one of the finest of hardy plants, with large, showy bright yellow flowers, produced in the greatest abundance from June till frost. As a cut flower they stand near the head among hardy plants, having long stems and lasting in good condition a week or more. Easily grown from seed, flowering the first year if sown early. Sow outdoors early in spring where plants are wanted to bloom covering seed one-half inch deep: thin to two feet apart. May also be sown in fall out doors. Height two feet.

GRANDIFLORA-Large flowered golden yellow. Pkt. $10 \mathrm{c} ; 1 / 4$ oz. $25 \mathrm{c} ; 1 / 2$ oz. $45 \mathrm{c}$.

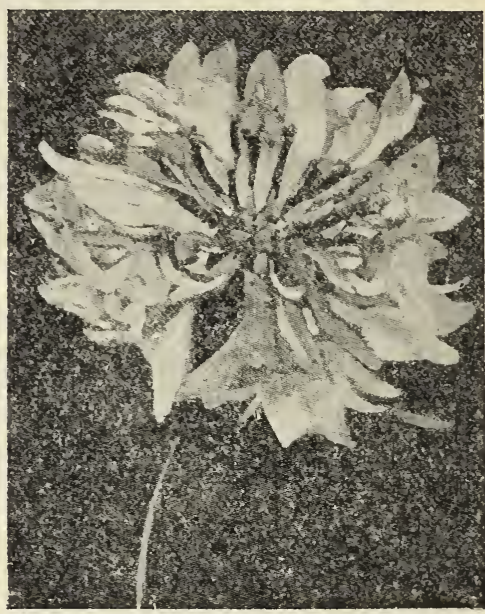

Bachelor's Button or Cornflower

\section{Cosmos}

Beautiful autumn-blooming, hardy and rapidgrowing annuals. They produce beautiful flowers in pure white, pink and crimson shades, furnishing an abundance of cut blooms for autumn decoration when other flowers are scarce.

Sow outdoors early in spring in rather light soil, not too rich, and preferably in a sunny situation. Cover the seed with one-fourth to one-half inch of fine soil firmly pressed down. If planted in rows, make the rows abnut two feet apart and when the young plants are well up, thin from four to six inches apart in the row.

EARLY-FLOWERING MIXED-This new strain of early-flowering Cosmos is very valuable for cooler sections. The flowers are of enormous size, measuring 3 inches or more in diameter. The plants grow 5 to 6 feet high and are covered with magnificent flowers during the fall until frost.

Pkt. $10 \mathrm{c} ; 1 / 4$ oz. $25 \mathrm{c} ; 1 / 2$ oz. $40 \mathrm{c}$; oz. $70 \mathrm{c}$.

EARLY-FLOWERING DOUBLE-A mixture of fine double flowers of large size. Pkt. 10c; $1 / 8$ oz. $35 \mathrm{c} ; 1 / 4$ oz. $65 \mathrm{c} ; 1 / 2$ oz. $\$ 1.10 ;$ oz. $\$ 1.90$.

\section{Canterbury Bell}

Handsome, easily grown herbaceous plants of stately branching habit and profuse bloom for beds and back grounds. They produce bellshaped or saucer-shaped flowers of rich color. Usually grown as a hardy biennial, but if seed is sown very early indoors, it may be treated as a tender annual. Sow seed outdoors early in spring. in rows about two feet apart. Cover lightly with fine soil, firmly pressed down. Thin to 18 inches apart. Protect in cold weather. Height $21 / 2$ feet.

MIXED-A mixture of single and double varieties. Pkt. $10 \mathrm{c} ; 1 / 8$ oz. $35 \mathrm{c} ; 1 / 4$ oz. $65 \mathrm{c}$.

\section{Dahlia Seed}

Dahlias can easily be grown from seed. If seed is planted early indoors and transplanted after danger of frost is past, many plants will bloom the first year. They produce their flowers in great abundance from August until frost. These half hardy perennials form roots which should be dug in the fall, allowed to dry and then stored in a frost proof place.

LARGE FLOWERED DOUBLE-A wonderful assortment of fine colors. Seed from double varities. Pkt. $10 \mathrm{c} ; 1-16 \mathrm{oz} .35 \mathrm{c} ; 1 / 8$ oz. $60 \mathrm{c}$.

CACTUS-FLOWERED MIXED-A well known and very popular type. Flowers are double of large size and many bright colors.

Pkt. $10 \mathrm{c} ; 1-16$ oz. $40 \mathrm{c} ; 1 / \mathrm{s}$ oz. $75 \mathrm{c}$ 


\section{SELECTED FLOWER SEED-Continued}

\section{Daisies}

Daises are very popular for borders and for filling in open spaces in the flower bed. The plants thrive in a fairly rich soil when they get plenty of sunshine. As soon as the ground is warm sow seed thinly and barely cover from view. SWAN RIVER DAISY - (Brachycome) Free flowering, dwarf growing annuals; covered the greater part of the summer with a profusion of bright blue flowers; excellent for borders and pot culture. Height 12 inches. Thin to stand 6 to 8 inches apart.

Pkt. $10 \mathrm{c} ; 1 / 8$ oz. $25 \mathrm{c} ; 1 / 4$ oz. $45 \mathrm{c}$.

ENGLISH DAISY OR BELLIS-A favorite perennial plant, but to get the best results it should be sown each year, usually sown in the spring but August is the best time for sowing. Grows 6 in. tall. Excellent for borders, lowbeds and rock gardens. White and various shades os rose and red mixed in double flowers. Thin to stand 6 inches apart.

Double Mixed-Pkt. 10c; 1/8 oz. 45̃c.

SHASTA DAISY-Splendid perennial plants with large single white flowers with yellow centers. The plants produce an abundance of bloom, borne on long stems and excellent for cutting. To get best results, sow seed in boxes indoors and when plants have made some growth, transplant to stand $11 / 2$ to 2 feet apart. Height 2 feet.

Pkt. $10 \mathrm{c} ; 1 / 8$ oz. $35 \mathrm{c} ; 1 / 4$ oz. $60 \mathrm{c}$.

\section{Delphinium}

\section{(Hardy Perennial Larkspur)}

The Delphinium with its long clustered spikes of beautiful irregular flowers, often with long spurs, is a most exquisite flower. They are very effective as background for borders and for planting among shrubbery. Sow seed in fall or early in spring, thin out to stand 1 to $11 / 2$ feet each way. A hardy perennial growing about three feet tall.

CHOICE MIXED-A balanced mixture of choice colors with beautiful long spikes.

Pkt. $10 \mathrm{c} ; 1-16$ oz. $25 \mathrm{c}$; $1 / 8$ oz. $40 \mathrm{c}$.

\section{Dianthus or Pinks}

Few flowers can equal these annuals in beauty and profusion of blooms. They are easily grown in any soil but make their finest display in a fairly heavy and fertile soil, developing into handsome plants which are simply covered with blooms all during late summer and fall. Height, 12 inches. Unexcelled for borders, beds or for cutting. Sow the seed the middle of April in the open. Cover the seed with $1 / 4$ inch of fine soil.

FINEST DOUULE MIXED-An unusually fine mixture of double flowers in great variety; of different colors and markings. The individual blooms are quite large and come in various shades of pink, rose, scarlet, crimson and maroon.

Pkt. $10 \mathrm{c} ; 1 / 8$ oz. $20 \mathrm{c} ; 1 / 4$ oz. $35 \mathrm{c}$.

\section{Dusty Miller}

This popular annual is a foliage variety of Centaurea, of graceful drooping habit of growth. It has finely cut silvery foliage, growing about 12 inches. Fine for bedding, vases hang ing baskets and pots; also extensively used for margins. As an edging to $a$ bed of darkleaved Cannas or Scarlet Sage these are particularly effective. Sow the seed early indoors, and transplant in May or sow outdoors when ground is warm. Pkt. $10 \mathrm{c} ; 1 / 8$ oz. $25 \mathrm{c} ; 1 / 1$ oz. $45 \mathrm{c}$.

\section{Feverfew}

An old garden favorite with dark green finely cut foliage, throwing up clusters of pure whit double flowers. A hardy annual 12 to 15 inches high. Sow the seed outdoors the latter part of April. They do best in a sunny location and are attractive either in beds, borders or as cut flowers. Cover with $1 / 8$ inch fine soil, thin to stand one foot apart. Pkt. 10c; 1/4 oz. $35 \mathrm{c}$.

\section{Forget-Me-Not}

This is a favorite old-fashioned flower, bearing in profusion, especially in fall and spring, clusters of dainty blue five-petalled blossoms. It thrives well in the shade or open border but flourishes best in a moist, shady situation.

For bloom the first year sow indoors in February or March, and transplant as soon as the ground is warm enough, or sow outdoors as early as possible, covering seed one-half inch deep; thin to six inches apart. Seed may also be sown in fall. Hardy perennial but usually does better if given some protection during winter.

ALPESTRIS, BLUE-Dwarf, free-flowering bushes. Excellent for borders or beds. Light blue flowers standing out sharply from the rich green foliage. Pkt., 10c; $1 / 8$ oz., 20c; $1 / 4$ oz., $35 \mathrm{c}$.

\section{Four-0'clock or Marvel-of-Peru}

Large and beautiful, old-fashioned plants of erect bushy nabit, about $2 \frac{1}{2} \mathrm{ft}$. high, which produce in profusion a succession of brilliantly colored tube-shaped flowers, that open about four oclock in the afternoon, remaining open all night and usually are closed before noon the next day. The flowers are red, white, yellow, or are striped and blotched in shades of these colors. A hardy annual. Very desirable for borders, along a wire fence, or as the background of a flower garden, blooming during the late summer and zutumn. Sow seed in spring in open ground after danger of frost is over, covering one-half inch deep. For best development allow two or three feet apart each way. They thrive in a loose loamy oil and need plenty of water during growing season.

TALL MIXED-A fine mixture of many bright colors. Pkt. 10c; oz. 20c; 4 oz. 55c.

\section{Foxglove or Digitalis}

Beautiful tall spikes of white, pink, rose, yellow, purple and mottled flowers. Grows 4 feet high. It is a stately plant, useful for planting in the mixed border. Seed may be sown outdoors after danger from frost is over, but for best results start in boxes and transplant. The seed is very small and should be covered lightly and kept moist until plants are well established, when they should be transplanted to two feet apart. May be sown outdoors in fall. Hardy biennial or perennial, usually blooming the second season. FINE MIXED-Pkt. $10 \mathrm{c} ; 1-16 \mathrm{oz}$. 25c; $1 / 8 \mathrm{oz}$. $40 \mathrm{c}$.

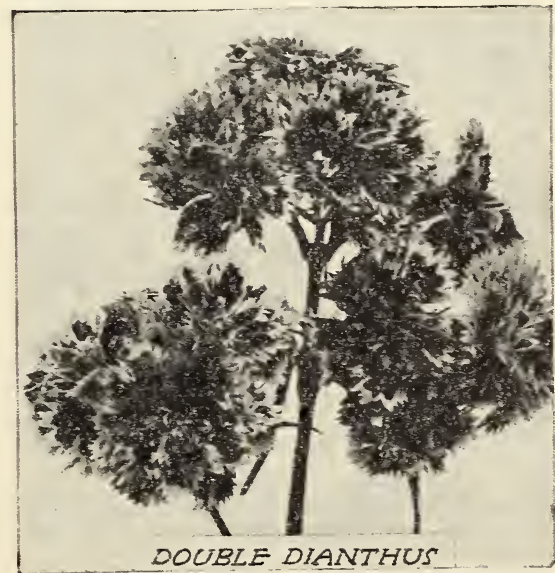




\section{SELECTED FLOWER SEED-Continued}

\section{Gaillardia or Blanket Flower}

Remarkable for the profusion, size and brilliancy of their flowers. They grow about 15 inches tall and continue in bloom from early summer till November. Excellent for beds, borders or for cutting. They thrive in almost any soil, require little or no protection and take care of themselves. Sow seed out doors early in spring; cover one-fourth inch deep. Make rows eighteen inches apart and thin eight to ten inches apart in the row; or a longer season of bloom may be secured by planting in frames and transplanting.

DOUBLE MIXED-These annuals are very easily grown. They are very showy and give a wonderful color effect. This mixture contains white, yellow and red in the proper proportions.

Pkt. $10 \mathrm{c} ; 1 / 4$ oz. $25 \mathrm{c} ; 1 / 2$ oz. $40 \mathrm{c}$.

\section{Hollyhock}

One of the finest tall flowering hardy perennial border plants. The foliage is an unusually attractive shade of green from which grow bold spikes of peony like blooms in exquisite shades and colorings. Sow seed $1 / 2$ inch deep, any time from early spring until early August in open ground and in the autumn transplant to permanent position two or three feet apart. The following summer they will bloom. The double varieties grow 6 to 8 feet high. Flowers measure 3 to 4 inches in diameter.

DOUBLE MIXED-A selection of the best colors that will help to set off any garden. Postpaid, pkt. 10c; 1/8 oz. 30c.

\section{Larkspur}

Quick growing and free-flowering annuals which produce stiffly erect spikes of beautiful flowers in great profusion. They are strictly annuals, being distinct from the Delphinium or Hardy Larkspurs in this respect. Sow seed $1 / 4$ inch deep as early in the spring as posoible where they are to bloom. When the young plants are well started, thin out or transplant to stand 6 to 12 inches apart. Very showy and easily cultivated.

The plants do best in cool and moist ground. Larkspurs are admirably adapted for borders or beds, but they are also very useful for cutting.

DOUBLE MIXED-Contains a mixture of the best tall annual Larkspur about 3 feet high and in fine color shades. Pkt. $10 \mathrm{c} ; 1 / 4$ oz. $25 \mathrm{c}$.

\section{Heliotrope}

Half hardy perennial; $11 / 2$ to 2 feet high. Splendid border and bedding plants, highly esteemed for the fragrance of their branching clusters of small flowers. The seed is hard to start and should be sown early in the spring, in mellow soil indoors, and when plants are one to two inches high, put into pots. Transplant to bed when three to four inches high. They thrive in a sunny location and need plenty of water when in bloom. While it is a perennial it will not stand any frost and is therefore started afresh every year, unless plants are removed to the house before frost comes. Can be started from cuttings.

GIANT HYBRIDS MIXED-Clusters measure 6 to 12 inches across. Their fragrance is delightful and pronounced. The colors range from white through shades of violet and blue.

Pkt. 10c: 1-16 oz. 30c; $1 / 8$ oz. 50c.

\section{Lobelia}

These half hardy annuals, usually about six inches high are charming plants, well adapted for bedding, pots or rockeries. They make a neat edging for beds of white star-like flowers and are very effective in masses, being covered with flowers a long time. They are grown extensively in hanging baskets. The flowers are usually blue with lighter center and are borne in neat clusters, each irregularly lobed flower being about five-eighths inch across. Seed may be sown outdoors after danger of frost is over; or start the plants in pots, in greenhouse or hotbed, early in spring and transplant in May to place outdoors. Cover seed very lightly.

FINEST MIXTURE-Pkt. $10 \mathrm{c} ; 1 / 8$ oz. $35 \mathrm{c}$. 


\section{SELECTED FLOWER SEED-Continued}

\section{Marigold}

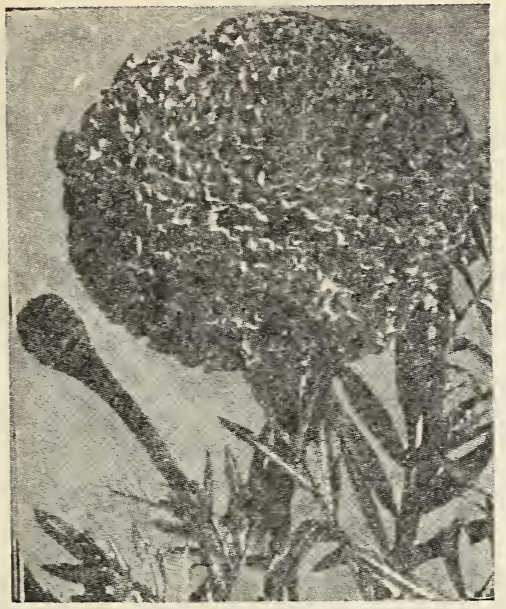

This is a fine old-fashioned garden plant with \& brilliant display of yellow and orange flowers. The foliage is bright green. The African varieties are tall, usually one and one-half to three feet, and are well adapted for large beds, backgrounds or mixed borders, while the French are more dwarf and are often used for borders and pot culture as well as bedding.

For best results start seed early indoors and transplant six inches apart when danger from frost is over, but good blooms of both varieties of Marigold are often successfully obtained from seed planted in the open ground after danger from frost is past. Make the rows one foot apart. Use well pulverized soil, preferably light sandy loam and cover the seed with about one-fourth inch of fine soil firmly pressed down. When about two inches high, thin six to twelve inches. Hardy annuals: in bloom till frost comes.

AFRICAN DOUBLE, MIXED-A well-balanced mixture, Pkt, $10 \mathrm{c}$ : $1 /$ oz. $25 \mathrm{c}$; 16 oz, $40 \mathrm{c}$

FRENCH DOUBLE MIXED-Includes wide range of colors. Pkt. $10 \mathrm{c} ; 1 / 4$ oz. $25 \mathrm{c} ; 1 / 2$ oz. $40 \mathrm{c}$.

\section{Mexican Fire Bush or Kochia}

This most popular ornamental annual is also known as Summer Cypress or Burning Bush. Makes a pyramidal-shaped, cypress-like bush two to three feet tall, with feathery light green foliage, deepening until it becomes a lovely crimson hue about September. Excellent for hedges along garden walks. Sow outdoors early in spring, covering one-fourth inch deep. Make the rows two feet apart and thin eighteen inches apart. For earlier blooming start indoors and transplant to open ground. Plt. $10 \mathrm{e} ; \mathrm{I} / \mathrm{oz} 20 \mathrm{e}$

\section{Mignonette}

A well known hardy annual, growing one foot high and producing dense cone-shaped flowerspikes. It is often used for cutting to combine in bouquets with other more pretentious flowers lacking its delicate and pleasing fragrance. Seed is usually sown outdoors after danger of frost is over and if sown at intervals in spring and early summer a succession of bloom, under favorable conditions, is assured till frost. Well pulverized soil, preferably light sandy loam, should be used and the seed covered one-fourth inch deep. Make rows one foot apart; thin to six inches. For very early blooming seed may be sown in the fall, or started indoors and transplanted. May also be grown in pots.

FTNEST MIXED-Plt. 10e; $1 / 4$ o. $25 \mathrm{e}$.

\section{Nasturtium}

For ease of eulture, duration of bloom, brillianey of coloring and general excellence, nothing excels these hardy annuals. All they need is a moderately good soil in a well-drained sunny position, and from within a few weeks from the time they are sown until hard frost comes there is an endless profusion of blossoms. After danger from frost is rast, sow seed one inch deep and thin plants to 6 inches apart for Dwarf Varieties and 16 to 20 inches apart for Tall or Climbing Varieties. One ounce sows 15 feet of row.

TALL VARIETIES MIIXED-A mixture of tho best giant flowering varieties. Pkt. 5c; oz. 15e ; 2 oz. $25 \mathrm{c} ; 1 / 4 \mathrm{lb}$. $45 \mathrm{c}$; lb. $\$ 1.35$.

DWARF VARIETIES MIXED-A mixtare of the very finest large flowering Dwarf Nastur tiums in existence. Pkt. $5 \mathrm{c}$; oz. 15c; 2 or. 25e; $1 / 4$ lb. $45 \mathrm{c} ; \mathrm{lb}$. $\$ 1.35$.

\section{Poppies}

These most beautiful hardy annuals and perennials are of easy and quick growth. Their gorgeous flowers are borne throughout the summer.

As early in spring as ground can be worked sow the seed, which is quite small, where the flowers are to bloom as the annual varieties do not bear transplanting. Pulverized soil, preferably light sandy loam, should be used. Make rows fifteen inches apart and cover seed onefourth inch deep. When two inches high, thin from six inches to one foot. To insure continuous bloom during a long season the flowers should be cut regularly and no seed pods allowed to form.

CALIFORNIA POPPY - Eschscholtzia (mixed colors)-This hardy annual growing one foot high is especially valuable for growing in flower beds or borders, also for cut flowers. This is a well balanced mixture of fine varieties of California Poppy producing bright showy sellow flowers. Sow where plants are to bloom.

Pkt. $10 \mathrm{c} ; 1 / 2$ oz. $30 \mathrm{c}$; oz. 50c.

SHIRLEY, DOUBLE HYBRIDS-These beautiful new hardy annuals produce large double and semi-double flowers in a wonderful range of colors. They are remarkable for their many delicate shades. about 20 inches high.

Pkt. $10 \mathrm{c} ; 1 / 2$ oz. $30 \mathrm{c} ;$ oz. $50 \mathrm{c}$.

DOUBLE PEONY-FLOWERED, MIXED-Large double flowers of all colors, borne most profusely. They are hardy annuals and closely resemble a small Peony. About $2 \mathrm{ft}$. high.

Pkt. 10c; $1 / 2$ oz. $30 \mathrm{c}$; oz. $50 \mathrm{c}$.

ICELAND POPPIES- While these are hardy perennials, they flower the first year from seed. blooming almost as quickly as the annual sorts. They are of graceful neat habit, with bright green fernlike foliage, formed in tufts, from which issues slender stalks from 12 to 18 inches high, bearing their brilliant flowers in endless profusion; most useful for cutting, for which purpose pick when in bud, and, if the seed pods are picked off, continue in flower the entire season. They remain evergreen throughout the winter, com into bloom early the following spring. SUNBEAM is an improved strain of robust, growing habit with long stems and large flowers. Colors white, lemon, yellow and orange scarlet.

Pkt. $10 \mathrm{c} ; 1 / 8$ oz. $30 \mathrm{c} ; 1 / 4$ oz. $50 \mathrm{c}$.

ORIENTAL POPPIES-These hardy perennials should be sown in early spring in the open ground as soon as it is fit to work. The plants disappear during July and August, appearing again as soon as the weather gets cool. Sow seeds where plants are to bloom. It is well to mark the places where they are planted with a stake to insure the roots against disturbance during their annual resting period.

The scarlet blooms are carried on long heavg stems about $2 \frac{1}{2}$ feet high. Pkt. $10 \mathrm{c} ; 1 / 8 \mathrm{oz}$. $30 \mathrm{c}$ : 


\section{SELECTED FLOWER SEED-Continued}

\section{Pansies}

These well known hardy perennials are usually grown as annuals or biennials. They are not hard to cultivate and bloom profusely for many months.

Seed may be sown indoors very early in spring, or a little later in the open ground, and transplanted when an inch high. Such plants will commence to bloom in June. If sown in July, the plants will bloom in the fall, or if sown in September, the following spring. Well pulverized soil should be used and the seeds covered oneeighth to one-fourth inch deep with fine soil firmly pressed down. The largest and best flowers are produced by young plants which have been grown rather slowly in a partially shaded situation, and in very rich soil; coolness and moisture are necessary. A situation sheltered from high winds and exposed to the morning sun is most favorable and frequent sprinklings are advantageous. Grown indoors pansies make a good winter blooming pot plant.

GIANT TRIMARDEAU MIXED-A complete mixture of all the giant flowering varieties. Flowers of richest and most varied shades. Plants very hardy and vigorous.

Pkt. $10 \mathrm{c} ; 1-16$ oz. $30 \mathrm{c} ; 1 / 8$ oz. $50 \mathrm{c}$.

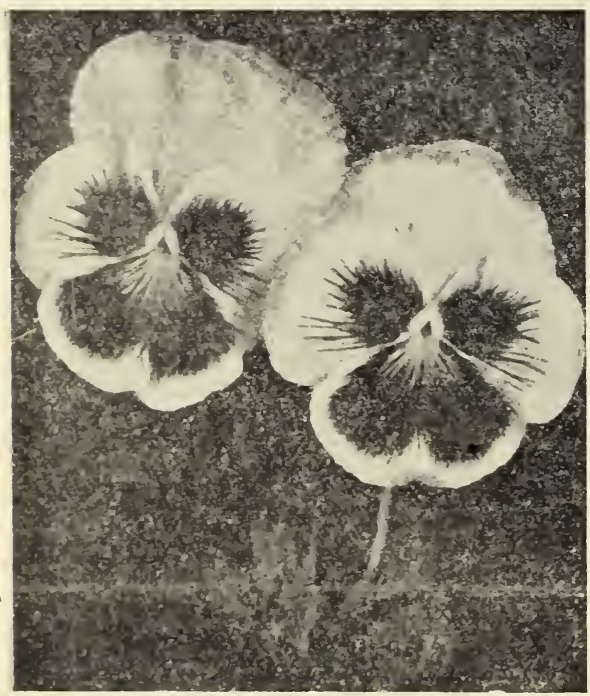

Giant Trimardeau Pansies

\section{Phlox Drummondi}

Nothing can surpass these beautiful annuals in the magnificent display of their many and brilliantly colored flowers. Sown in the open ground in the early spring or fall, they come into flower in June, and are literally covered with bloom till frost. Use well pulverized soil, preferably sandy loam. Make the rows one foot to fifteen inches apart and cover the seed with one-fourth inch of fine soil firmly pressed down. When two inches high, thin six to eight inches apart. The compact, bushy plants are beautiful for borders. They grow 15 inches tall. The closely formed fower-heads with their long stems will make fine cut-flowers.

FINE MIXED-Is composed of the finest and most distinct varieties and will give a greatly varied assortment of brilliant colors. The trusses are large, well rounded, and closely formed, and the individual florets are of the largest size.

Pkt. $10 \mathrm{c} ; 1 / 8$ oz. $20 \mathrm{c} ; 1 / 4$ oz. $35 \mathrm{c}$.

\section{Petunia}

These tender perennials blooming the flrst year and growing about one and one-half feet high, are unsurpassed for massing in beds. They are also used along walks and driveways and are often grown in window boxes. Their richness of color, duration of bloom and culture will always make them popular. They endure drought exceptionally well. The seed may be sown outside in well prepared ground early in May; to facilitate sowing the seed may be mixed with sand or dry soil scatter the mixture and just press in the ground. Thin the seedlings to 8 to 12 inches apart. It is an advantage to sow the seed which is very fine and costly, early in boxes in the house or hotbed for window boxes, baskets and also for bedding out.

DOUBLE PETUNIA-FANCY FRINGED-An excellent, carefully hand-pollenized strain yielding a large percentage of plants having double, finely fringed flowers. A splendid variety of colors and many beautiful combinations. Seed very costly.

Pkt. $30 \mathrm{c} ; 2$ for $50 \mathrm{c}$.

BURPEE'S DEFIANCE-This strain of Petunias has a reputation for enormous size and range of colors. The colors are indescribably rich and varied, including many fine self colors and a good assortment of mottled, striped, blotched, and veined flowers. Pkt. 25c; 2 for $45 \mathrm{c}$.

BALCONY PETUNIA-For window or porch boxes, dry banks, terraces, or among rockwork, the Balcony Petunias supply an unsurpassed floral effect until frost. Flowers measure nearly 3 inches in diameter.

Pkt. $15 \mathrm{c} ; 1-16$ oz. $55 \mathrm{c}$; 1/8 oz. $\$ 1.00$.

HYBRIDA, MIXED-A fine mixture of all bedding varieties and many others belonging to this class. Plt. $10 \mathrm{c}$; $1-16$ oz. $20 \mathrm{c}$; 1/8 oz. $35 \mathrm{c}$.

\section{Portulaca \\ (Sun Plant or Moss Rose)}

A very beautiful hardy annual, unsurpassed in brilliancy. The rlants are low-growing and creep along the ground. They thrive well in almost any mer weather. The finest flowers are produced the mer weather. The finest flowers are produced the there are heavy dews at night. Sow seed outdoors, after weather is warm and settled, where doors, aps one foot apart. They should have a sunny situation. Well pul. verized soil should be used but it does not need to be rich. Cover seed about one-eighth inch deep Thin to two inches apart. For massed beds seed can be sown broadcast, the soil sifted on and the whole bed carefully pressed with a board. Height about nine inches.

DOUBLE MIXED. Is unsurpassed for brilliancy and beauty. Pkt. $10 \mathrm{c} ; 1-16 \mathrm{oz} .30 \mathrm{c}$.

\section{Scabiosa or Mourning Bride}

This hardy annual is an old fashioned but most attractive flower. Its great abundance and long succession of rich colored, fragrant blossoms on long slender stems nearly 2 feet in length, make it one of the most useful decorative plants of the garden. Desirable for cutting as well as for beds arower heads about two inches and borders. Flower heads about two thimbleshaped cone, resembling a pin cushion. Seed may be sown as soor as ground can be worked; for earlier blooming sow in hotbed early in spring and transplant 18 inches apart.

LARGE FLOWERED DOUBLE MIXED-A complete mixture of all the finest colors.

Pkt. 10c; $1 / 4$ oz. 30c; $1 / 2$ oz. $50 \mathrm{c}$. 


\section{SELECTED FLOWER SEED-Continued}

\section{Sweet Peas}

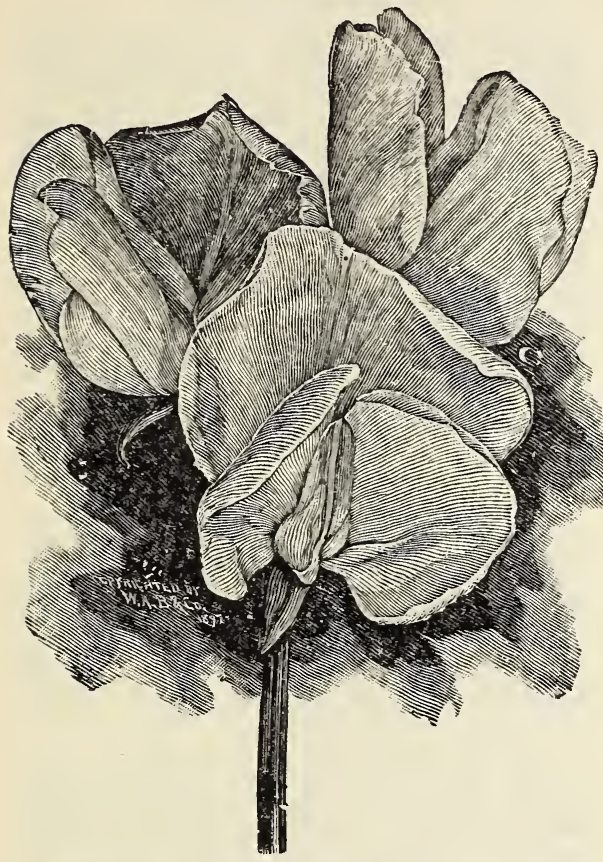

Sweet Peas should have a place in every garden. Their long blooming season extends from early summer until very hot dry weather and no other climber equals it for cutting either for use in bouquets or for table decoration.

CULTURE-Early in spring make a trench three to four inches deep in rich, mellow soil, so arranged that no water can stand in it and plant the seed in the bottom, covering at first only one inch deep. Sweet Peas are often a little difficult to start. If the soil is too dry they will remain a long time without germinating; if it is too wet and cold they will not sprout at all. In soils composed largely of clay, put about one inch of sand in the bottom of the trench and sow the seed on this, covering with more sand. Cover the row with a board to shed the rain and protect the soil from the hot sun but remove this as soon as the young plants appear. When the plants are two inches high, cultivate and as they grow gradually fill up the trench. When the plants are about five inches high it is desirable to furnish some support for the vines to run upon, preferably a wire netting firmly supported by stakes to prevent sagging, but strings or brush are often used with satisfactory results.

Early planting, thorough cultivation and plenty of fertilizer are necessary for best results. Roots should not be allowed to become too dry. Water should be applied thoroughly once or twice a week in dry weather, early in the morning or late evening.

Fall planting, usually after October 15th, has proven very successful in this section and often insures better growth and earlier blooming. Planting is the same as in spring except that the seed should be firmly covered with soil which should be somewhat ridged above the rows to improve drainage. In freezing weather the rows should be covered with a mulch of litter or manure which should gradually be removed upon the approach of warm weather.
The blooms should be picked before they form pods or the plants will soon stop flowering. One ounce will plant a single row of 25 feet.

SPENCERS OR ORCHID FLOWERED, MIXED - This mixture contains the cream of the finest named Spencers, which are the largest sweet peas grown. Pkt. $10 \mathrm{c} ;$ oz. $25 \mathrm{c} ; 1 / 4$ lb. $75 \mathrm{c} ; \mathrm{lb} . \$ 2.50$.

\section{Scarlet Sage or Salvia}

The well-known Scarlet Sage is a handsome flowering, tender perennial of branching, bushlike growth. To have Salvia in bloom early in summer, the seed should be sown in March, in boxes of light rich soil, $1 / 4$ inch deep; placed in a warm, sunny window, and when the young plants are well started, they should be set in pots and kept growing rapidly until the nights are warm. Then they should be planted 3 feet apart in the flower-bed.

SPLENDENS (Large Flowering Scarlet Sage). This is by far the largest-flowering variety of Scarlet Sage. Well-grown plants measure 4 feet across and 3 to 4 feet high.

Pkt. $10 \mathrm{c}$; $1-16$ oz. $30 \mathrm{c} ; 1 / 8$ oz. $50 \mathrm{c} .1 / 4$ oz. $85 \mathrm{c}$.

\section{Salpiglossis or Velvet Flower}

These Petunia like flowers are easily grown and make very showy bedding or border plants with richly colored, funnel-shaped flowers which are borne on long graceful stems. The flowers of purple, scarlet, crimson, yellow, buff, blue or almost black are beautifully veined or penciled. They are produced abundantly during the entire summer, and are certainly worthy of more general cultivation than they have heretofore had. As they lend themselves readily to artistic arrangement they are very desirable for cut flowers.

For early blooming seed may be started indoors as early as the middle of March and the young plants set out in the garden one foot apart, or seed may be sown outdoors after settled warm weather. Blooms from August to October. Half hardy annual; about two feet high.

FINEST MIXED-Flowers of many beautiful shades, finely veined or penciled. A choice mixture of large flowering varieties. Pkt. 10c: $1 / 8$ oz. $20 \mathrm{c} ; 1 / 4$ oz. $35 \mathrm{c}$.

\section{Stocks or Gilliflower}

The Stock is one of the most popular annuals, either for bedding or pot culture; for brilliancy and diversity of color, fragrance, profusion and duration of bloom it is unsurpassed. Sow outdoors early in spring, using well fertilized, carefully pulverized soil and cover seed with onefourth inch of fine soil firmly pressed down. Make the rows fifteen inches apart; thin to six inches apart. For earlier blooming start indoors and transplant when the ground is warm.

TEN WEEKS MIXED-A large flowering, double, early blooming variety of many fine color shades, borne profusely on strong, stocky spikes. Height 15 to 18 inches. Pkt. $10 \mathrm{c} ; 1 / 8$ oz. $35 \mathrm{c}$.

CUT AND COME AGAIN-Beautiful mixture of double flowers borne on fine strong stems. Particularly fine for cutting. Grows 18 inches tall. Pkt. $10 \mathrm{c} ; 1 / 8$ oz. $35 \mathrm{c} ; 1 / 4$ oz. $55 \mathrm{c}$.

\section{Straw Flower or Everlasting}

Large full, double daisy-like flower heads with prominent center, produced in various shades on stems of good length. They make a fine effect in beds and borders and as cut flowers, and also desirable as dried specimens and for use in making winter bouquets. For this purpose the flowers should be gathered when on the point of expand. ing. Sow early in spring; cover with $1 / 4$ inch fine soil; thin to one foot apart each way. Hardy annual itwo to two and one-half feet high

CHOICE MIXED-Contains all the brightest colors properly blended. Pkt. $10 \mathrm{c}$; $1 / 4$ oz. $35 \mathrm{c}$. 


\section{SELECTED FLOWER SEED-Continued}

\section{Snapdragons}

Antirrhinums or Snapdragons are undoubtedly one of the best cut flowers which can readily be grown from seed, while for beds or borders they are a constant source of pleasure, being in flower all the time. For blooms the first season outdoors, sow seed very early under glass and transplant to open border as soon as the ground is warm and dry, in rich loamy soil in a sunny situation, setting one foot apart each way and giving them plenty of water, cover plants with a mulch on approach of cold weather. Seed may be sown in the open from May to September: cover thinly with fine soil firmly pressed down. Thin to twelve inches apart. Fall grown plants may be transplanted into pots and flowered in the house. Snapdragons are hardy annuals or biennials which bloom the first year, and so they are treated like annuals and sown every year.

HALF DWARF MIXED-A complete mixture of the tallest of this variety growing about 15 inches high. Covered with magnificient spikes in brilliant colors. Pkt. $10 \mathrm{c}$; $1-16 \mathrm{oz} .35 \mathrm{c}$.

\section{Sunflowers}

Hardy annuals, which grow readily in almost any soil but do best on unshaded land well supplied with moisture. Sow seed outdoors in spring after danger of frost is over, in rows two to three feet apart and cover about one-half inch deep. When the young plants are about four inches high, thin to 2 feet apart.

DOUBLE CHRYSANTHEMUM-FLOWEREDA wonderful Sunflower with fully double blooms like a giant Chrysanthemum 6 to 8 inches in diameter. The heads are made up of thousands of small fringed retals, forming a broad thick flower. The plants grow nearly 7 feet tall and are cove ered with the mammoth blooms. The color is a bright golden yellow.

Pkt. $10 \mathrm{c}$; $1 / 2$ Oz. $35 \mathrm{c}$; oz. $55 \mathrm{c}$

MINIATURE-Covered with hundreds of small double flowers; of brightest yellow, of pyramidal krowth, with bright neat foliage. Grows 3 feet tall. The flowers are fine for cutting.

Pkt. $10 \mathrm{c} ; 1 / 2$ oz. $25 \mathrm{c}$; oz. $40 \mathrm{c}$.

LARGE RUSSIAN-This has very large single heads borne at the top of a single unbranched stalk often $10 \mathrm{ft}$. tall. Used extensively for feeding poultry and is an excellent egg producer. Sow seed as soon as ground is fit for planting corn, in rows three to four feet apart and at least two feet apart in row. Cultivate the same as corn. This variety will yield 1000 pounds or more of seed per acre. Sow 5 lbs. to the acre in drills 36 inches apart

Pkt. 5c; $1 / 2$ lb. 20c; lb. 30c; 2 lbs. $55 \mathrm{c}$.

For larger quantities inquire for prices.

\section{Sweet William}

A well-known, attractive, free-flowering hardy perennial, growing about 11/ ft. high and pro ducing a splendid effect in beds and borders with their rich and varied flowers. The colors are exceedingly varied, ranging from white through many shades of rose, lilac, red, carmine, crimson and maroon to nearly black, usually two shades to each plant. Seed may be sown outdoors any time from very early in the spring until the early fall, preferably in rich, mellow soil, in rows one foot apart. Cover seed with one-fourth inch of fine soil firmly pressed down. When two inches high, thin to six inches apart. There are usually no flowers until the second season, but if seed is started very early under glass and transplanted. blooms may be had late in autumn. The old clumps may be divided but it is usually more satisfactory to start vigorous young plants each year.

DOUBLE MXED-Fine double flowers in a sreat variety of colors. Excellent for beds a borders. Pkt. $10 \mathrm{c}$; $1 / 8 \mathrm{oz} .25 \mathrm{c}$; $1 / 4 \mathrm{oz} .40 \mathrm{c}$.

\section{Verbena}

One of the most popular flowers lending itself willingly to many uses. For beds, borders, mounds, vases and window boxes it is particularly fine, and is frequently used for an undicular to tall plants like lillies. Verbenas usually flower well from seed sown in open ground in May. Germination will be hastened if the seed is soaked in lukewarm water before planting. It is desirable to have the soil well fertilized and carefully pulverized. Cover seed about onefourth deep. When the young plants have three or four leaves transplant in rows two feet apart and about twenty-four inches apart in the row, choosing preferably a sunny situation. Earlier blooming may be had if plants are started indoors and transplanted in the open ground after danger of killing frost is over. Hardy annual trailer one foot high.

MAMMOTH MIXED-Extra choice mixture of arge flowering varieties.

Pkt. $10 \mathrm{c} ; 1 / 8$ oz. $30 \mathrm{c} ; 1 / 4$ oz. $50 \mathrm{c}$.

\section{Wallflower}

A favorite garden flower, producing large spikes of fragrant blooms of many colors. Useful for beds, borders and winter house plants. Sow early and transplant while small. As cold weather approaches put into pots for winter blooming. Tender perennial growing about $11 / 2 \mathrm{ft}$. high.

TALL DOUBLE MIXED - The spikes are closely set with double flowers of many shades, including chocolate-brown, orange, purple, crimson, bright red, and many other fine colors.

Pkt. $10 \mathrm{c}$; $1-16$ oz. $40 \mathrm{c}$; $1 / 8$ oz. $70 \mathrm{c}$.

\section{Wild Garden Flowers}

Under this heading we offer a mixture of the easiest and surest growing flowers that can be sown broadcast or in drills and which, with little care, will produce a bright effect in places that otherwise would be nothing but a collection of unsightly weeds. This mixture will furnish an abundance of flowers for cutting. Sow the seed in well prepared open ground, when danger of cold weather is past, covering lightly with finely pulverized soil firmly pressed down. Keep the weeds out and water occasionally in dry weather. Pkt. $10 \mathrm{c}$; 0z. $25 \mathrm{c}$; $1 / 4 \mathrm{lb}$. $70 \mathrm{c}$; 1 lb. $\$ 2.25$.

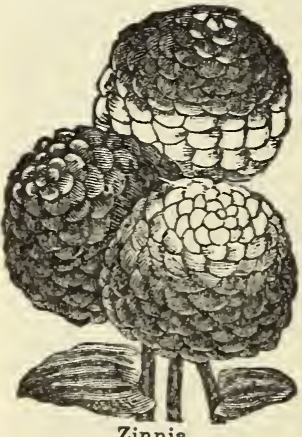

\section{Zinnia}

Some times called Youth and Old Age, suitable for gardens and for cutting. Zinnias grow well and bloom freely even under the most adverse circumstances of location and weather, and may be counted upon for a continuous show of blooms from July until frost. Sow the seed early in spring, in open ground in good rich soil, in rows one and onehalf feet part, covering about $1 / 4$ inch deep. When the plants are one to two inches high, thin to six inches apart. Half hardy annual growing two to three feet tall. Start under glass for earlier blooming.

GIANT MAMMOTH MIXED-This magnificent large-flowered type is unsurpassed. The blooms are of immense size when well grown, averaging $81 / 2$ to $41 / 2$ inches in diameter and often 3 to 4 inches in depth. Pkt. 10c; 1/8 oz. 20c; $1 / 4$ oz. $85 \mathrm{c}$.

DAHLIA FLOWERED MIXED-A complete mixture of all the best colors. Flowers are borne on long sturdy stems above the foliage from midsummer until frost. Flowers of immense size.

Pkt. $10 \mathrm{c} ; 1 / 8$ oz. $30 \mathrm{c} ; 1 / 4$ oz. $50 \mathrm{c}$. 


\section{VINES OR CLIMBING FLOWERS}

\section{Balloon Vine or "Love in a Puff"}

A graceful tender annual climber, rapidly growing 6 to 10 feet high. Small white flowers, which eventually turn into a seed pod resembling a balloon and for this reason of great interest to children. Sow the seed outdoors in open ground early in spring. Covering with $1 / 2$ inch of fine soil. Plant should have some support to run upon

Pkt. $10 \mathrm{c} ; 1 / 4$ oz. $15 \mathrm{c} ; 1 / 2$ oz. $25 \mathrm{c}$.

\section{Black-Eyed Susan or Thunbergia}

A half hardy annual and very elegant, slendergrowing climber rapidly covering wire trellises and also useful for vases in the garden or house. Grows about $4 \mathrm{ft}$. high. They are very attractive if grown simply trailing on the ground. The flowers are white, light yellow and deep orange with a black eye. Blooms continuously from June until October. Sow the seed indoors in March or April or out doors in May. Thin out or trangplant to twelve inches apart.

Pkt. $10 \mathrm{c} ; 1 / 8$ oz. $25 \mathrm{c}$; $1 / 4$ oz. $40 \mathrm{c}$.

\section{Cardinal Climber}

A rapid growing annual climber which if plantA in a warm sunny situation, will attain s height of twenty feet in a season. The brilliant scarlet flowers are not large, but are borne in such profusion as to almost cover the vines from top to bottom. They bloom all during summer and fall until frost. The foliage is quite dense and the leaves fringed. Seed is usually sown outdoors early in spring in the row where the plants are to remain. Cover seed one-half inch deep. Germination will be hastened if the soil is warm and kept in moist condition. Thin the young plants six to eight inches apart. If very early blooming is desired, seed should be started indoors.

Pkt. $10 \mathrm{c}$; $1 / 8$ oz. $40 \mathrm{c} ; 1 / 4$ oz. $75 \mathrm{c}$.

\section{Clematis-Paniculata}

Splendid hardy perennial climber growing 12 to 15 feet and covered with a dense mass of pure white star-like fragrant flowers that bloom for several weeks. A fine climber for porches, ete. and very easily grown. Sow early in the spring and very easily grown. Sow early in the spring pulverized soil firmly pressed down.

Pkt., 10c; 1/8 oz., 20c; 1/ oz, 30c.

\section{Cobaea Scandens or Cathedral Bells}

A half hardy perennial of rapid growth, attaining a height of 20 feet during the season; valuable for covering trellises, arbors, trunks of trees, etc will cling to any rough surface. Large, bellshaped blue flowers. In planting, place seeds edgewise and merely cover with light soil ; to get early results start the seed indoors in March or April in rather dry soil, or sow out-of-doors in May. Pkt. $10 \mathrm{c} ; 1 / 4$ oz. $25 \mathrm{c}$; $1 / 2$ oz. $40 \mathrm{c}$; oz. $70 \mathrm{c}$.

\section{Cypress Vine}

One of the most popular vines, with very delicate fern-like foliage, and masses of beautiful, small, star-shaped scarlet flowers. Sow in May, first soaking the seeds in warm water for a few hours; cover seed one-half inch deep. Soil should be warm and kept moist. Tender annual growing 15 feet tall. May be grown in porch or window boxes. Pkt. $10 \mathrm{c}$; $1 / 2$ oz. $25 \mathrm{c}$; oz. $45 \mathrm{c}$.

\section{Kenilworth Ivy}

A well-known trailing tender perennial which will seed itself from year to year and is most useful for covering rock-work or stumps. Small, inconspicuous, lilac-colored flowers. Sow early in spring in open ground, covering seed lightly with pulverized soil firmly pressed down. It can be sown in boxes or hanging baskets any time of the year. Grows about $4 \mathrm{ft}$. high.

Pkt. $10 \mathrm{c} ; 1 / 8$ oz. $30 \mathrm{c}$; $1 / 4$ oz. $55 \mathrm{c}$.

\section{Kudzu Vine}

This is a perennial climber which rearly starts new shoots from the crown of the roots. One of the most rapid growing of all climbers, providing a dense screen of large, rich green leaves. The purple flowers are borne in clusters. Well-grown vines attain a height of 40 to 50 feet in a single season. The seed can be started indoors in March or in open ground in May. Protect the roots with straw during severe freezing. Soak seed before planting.

Pkt. $10 \mathrm{c} ; 1 / 4$ oz. $35 \mathrm{c} ; 1 / 2$ oz. $55 \mathrm{c} ;$ oz. $85 \mathrm{c}$.

\section{Moon Flower}

These beautiful tender annuals grow rapidly and will reach a height of 20 to 30 feet. The foliage is large, dense and luxuriant, affording splendid shade for porches. Plant the seed one inch deep in rich soil in spring when the ground is warm. soak seed for 12 hours in warm water before planting. The flowers open at sundown.

WHITE-SEEDED-The vines bear thousands of immense white flowers, many measuring 6 inches across. Pkt. $10 \mathrm{c} ; 1 / 2$ oz. $30 \mathrm{c} ; 0 \mathrm{z} .50 \mathrm{c}$.

\section{Morning Glory}

A handsome showy climber of easy culture and suitable for covering arbors, windows, treillises, old stumps, etc. The flowers are most brilliant in the morning. Hardy annual, growing $15 \mathrm{ft}$. high Seed is sown outdoors early in spring in row where plants are to remain. Well pulverized soil should be used and the seed covered $1 / 2$ inch deep.

MMPERIAL JAPANESE, MIXED-A strong grower with enormous flowers in many soft and delicate shades. Do not sow until the weather is quite warm and the nights are settled. It climbs readily and blooms freely. Pkt. $10 \mathrm{c}$; 1/2 oz. $20 \mathrm{c}$.

\section{Scarlet Runner}

An annual, growing 15 feet high. This bean produces a rapid growing vine; bearing large sprays of bright scarlet flowers. Very ornament al. Sow three inches deep, when all danger of frost is past. Thin to stand 12 to 18 inches apart. Pkt. $5 \mathrm{c}$; $1 / 4 \mathrm{lb} .15 \mathrm{c}$; $16 \mathrm{lb}$ lb. $25 \mathrm{c}$.

\section{GOURDS}

Interesting and very useful trailing annuals with curiously shaped fruit, commonly known as Ornamental Gourds. The vines are of easy culture and make a rapid growth, so are much used for covering old fences, trellises, stumps, etc. The foliage is ornamental, and the markings of some of the fruit extraordinary. Do not plant the seed till danger of frost is over, and select light, rich soil and a sunny situation. Leave 2 or 3 plants to a hill and water freely.

MIXED GOURDS-This includes a general mix. ture of all the different gourds from the small to the large-sruited varieties.

Pkt. $10 \mathrm{c}$; $1 / 2$ oz. $25 \mathrm{c}$; oz. $40 \mathrm{c}$.

\section{Castor Oil Bean-Ricinus}

A half hardy annual growing 12 to 14 feet high and producing ornamental plants with palm like foliage and showy fruits, giving to the garden magnificent sub-tropical effects : even a single plant forming a pyramid of leaves. Also considered valuable as an aid in driving moles out of the garden. Castor Oil Bean is a gross feeder and does best in rich moist soil.

CHOICE MIXED-Very beautiful and of tall, strong growing habit in many beautiful colors. They need no support.

Pkt. $5 \mathrm{c}$; oz. 20c; 4oz. 55c; 1lb. $\$ 1.90$. 


\section{CHEROKEE BRAND CLOVER SEED}

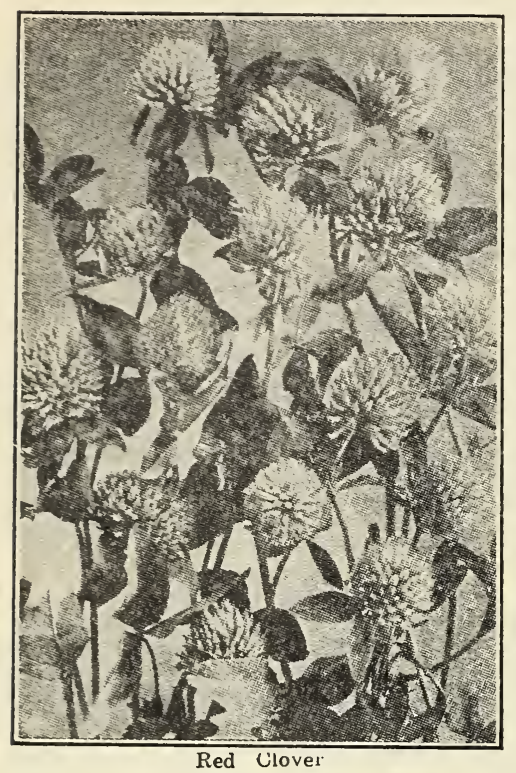

\section{Alsike Clover}

Alsike clover grows thicker, has a finer stem than red clover, has plenty of leaf, and makes better hay and more and better grazing than red clover and will grow on soils too acid, too wet, or too deficient in lime to produce a paying crop of other clovers. It is hardier and will stand greater extremes of heat and severely cold weather than any other clover. It is adapted to a variety of soils, succeeding on light upland and loamy as well as on bottom lands; alsike clover hay also contains a higher per cent of digestible protein. Sow 6 to 8 lbs. per acre. $1 / 2$ to 1 inch deep.

Postpaid lb. 35c; 2 lbs. $70 \mathrm{c}$; pk. $\$ 4.80$ 1/2 bu. $\$ 9.25$; bu. (60 lbs.) $\$ 18.00$.

Not prepaid (bags extra), about $\$ 17.00$.

\section{Crimson Clover}

An annual of French origin, makes a growth from 20 to 30 inches high, has a bright crimson blossom from $11 / 2$ to 3 inches long, and when in full bloom, is a thing of beauty It is a winter crop, and should be sown in July, August or September. As a manurial crop its worth in fertilizer value is hard to compute, being equal to one to three tons of commercial fertilizer.

Sow Crimson Clover on every piece of land that will be unoccupied by another crop next winter. Whether you grow it for grazing, for hay or for improving your land, it will pay handsomely.

If sown at last working of corn there is no extra labor involved and the only expense is the cost of the seed. Sow 15 to 20 lbs. per acre, 1 to 2 in. deep. Seed should be inoculated with Stimugerm. Write for prices.

\section{Japan Clover or Lespedeza}

Recommended especially for grazing erop on waste or idle lands and worn out soils. Once started it soon spreads but does not become a pest as it is easily subdued by cultivation. Roots penerate and break up hard sub-soils and gather nitrogen from the air. Relished by stock. Sow in spring or fall 20 to $25 \mathrm{lbs}$. per acre. Can be sown with other elovers, Red Ton, and Bermuda Grass. Postpaid, lb. 30c ; 2 lbs. $55 \mathrm{c}$; 5 lbs. $\$ 1.20$; 10 lbs. $\$ 2.30$; bu. (25 lbs.), $\$ 5.50$. Not prepaid (bags included), about $\$ 5.00$ bu.

\section{"Cherokee Brand"}

Represents a superior quality of Clover Seed recleaned and tested for high purity and strong germination. The wing of clover seed is absolutely essential to proper crops and to keep up the fertility of the land. imestone will quickly bring it back to proper shape. It a good time to fertilize when you sow clover as it not increases the yield of clover, but prepares the land r the grain or other crops that are to follow. Use 300 $400 \mathrm{lbs}$. to the acre.

Prices on clovers fluctuate and those quoted are only proximate. When you are ready to buy, write for rm quotations. Inoculate all clovers with Stimugerm

AGS ARE INCLUDED IN POSTPAID PRICES

ON FIELD SEEDS. AT NOT PREPAID PRICES

ON FIELD SEEDS, WHERE CHARGE IS MADE

FOR BAGS, THE CHARGE IS AS FOLLOWS :

FOR BUSHEL OR MORE $40 \mathrm{c}$ EACH.

\section{Red Clover}

This valuable perennial is not only one of the most exchent Hay and Forage crops, but it is a great Boil Red Clover can be cut 2 or 3 years from ne seeding, and on good land will yield two cuttings year. When sown alone use 10 to 12 lbs. per aere, to 1 in. deep. Excellent results are obtained by $80 \mathrm{w}-$ for hay, a mixture of 1 bu. of Orchard Grass, 1 bu. all Meadow Oat Grass with 8 lbs. of Red Clover to an re. If to be used also for pasture, an addition of 6 s. Red Top or Herd's Grass to the above mixture will

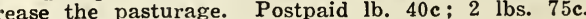

$\$ 5.15 ; 1 / 2$ bu. $\$ 10.00$; bu. (60 lbs.) $\$ 19.00$.

\section{ot prepaid (bags extra), about $\$ 18.00$ per bu.}

\section{Mammoth or Sapling Clover}

This is similar to Red Clover, both in appearance of the seed and its habits of growth, the difference being that it usually grows larger and is later in maturing $I t$ is considered superior as a soil improver on account of the extra growth. It is a good variety for thin soils, or to seed with Timothy, as it matures about the same time. Sow 10 to 12 lbs. per acre by itself or $6 \mathrm{lbs}$. of Clover and $8 \mathrm{lbs}$. of Timothy. Postpaid lb. $45 \mathrm{c} ; 2$ lbs. $85 \mathrm{c}$; pk. $\$ 5.65$; $1 / 2$ bu. $\$ 11.00$; bu. (60 lbs.) $\$ 20.00$.

Not prepaid (bags extra), about $\$ 19.00$.

\section{White Dutch Clover}

This perennial does well in nearly all parts of the South. In this section it is indigenous to all kinds of soils. Is especially valuable and largely used in Lawn and Pasture Mixtures. It makes a small, close, compact growth. If sown alone, sow 6 to $8 \mathrm{lbs}$. an acre; more largely sown with other grasses; in this case, use half the amount. Sow in either spring or fall, but not in hot summer weather. Postpaid lb. 55c; 2 lbs. $\$ 1.00 ; 5$ lbs $\$ 2.25$ 10 lbs. $\$ 4.25$. Not prepaid (bags extra), lb.45c; 2 lbs. $85 \mathrm{c} ; 5$ lbs. $\$ 2.00 ; 10$ lbs. $\$ 3.90$.

\section{White Blossom Sweet Clover}

\section{(Scarified Seed)}

Wherever dairy farming is practiced, the pasture problem is becoming a serious one. On account of the large amount of forage produced by Sweet Clover (a biennial) and the ease with which it can be grown on almost any soil, it use has practically doubled in the last few years. When cutting for hay, cut it tall : then you will have a good second crop as the tall stubble will bud out all around the stalk and many new shoots will start up. If cut low, within three or four inches of the ground, no second growth will result and the roots will die. This applies also to pasturing. Do not turn stock into Sweet Clover pasture until the growth is at least foot and a half tall. If this is done, the new growth will furnish constant pasture all season. Very valuable for bee pasture. Always inoculate seed with Stimugerm. Sow 12 to 15 lbs. per acre, $1 / 2$ to 1 inch deep. Postpaid lb. 20c; 2 lbs. $35 \mathrm{c}$; pk. $\$ 2.30$; $1 / 2$ bu. $\$ 4.25 ;$ bu. (60 lbs.)

$\$ 8.00$. Not prepaid (bags extra), about $\$ 7.00$. 


\section{ALFALFA OR LUCERNE}

Alfalfa is a good investment on certain kinds of land in Western North Carolina. Once established, it lasts for years and yields 3 to 5 cuttings of nutritious and palatable hay each season. To insure permanency, it must be cut every time it comes into bloom. It does not exhaust the soil, but enriches it

Sow Alfalfa only on deep, well-drained, good land that is not underiaid by a stiff, hard pan that the roots cannot penetrate. The land should contain an abundant supply of decomposed vegetable matter; a green crop turned under and lime at the rate of three tons to the acre. Do not sow on weedy land and keep free from weeds at all times. Do not attempt to grow Alfalfa without inoculating, except on fields where it has previously been grown. Sow 300 to 500 lbs, of soil from an Alfalfa Field on each acre; or use Stimugerm, described on this page.

Sow 20 to 30 lbs. to the acre broadcast. In the spring sow about the same time as oats are sown in this section. It may also be sown from August to October 1st. Corer one inch deep in light, loamy soil, three-fourths to one inch in heavier soils. We offer North Western grown seed, a type that has done well in Western North Carolina. We do not advise alfalfa unless soil snd drainage conditions are right and the planter is willing to start the crop correctly as outlined above. Postpaid, lb., $40 \mathrm{c}$; pk., $\$ 5.00$; $1 / 2$ bu., $\$ 9.75$; bu (60 lbs.), $\$ 19.00$. Not prepaid (bags extra), pk., \$4.75; $1 / 2$ bu., $\$ 9.25$; bu., $\$ 18.00$. Before buying, ask for current prices.

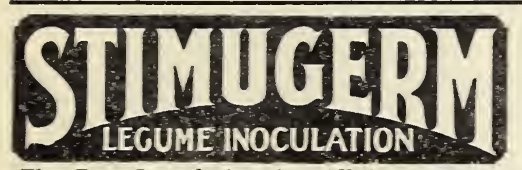

The Best Inoculation for All Legume Seeds

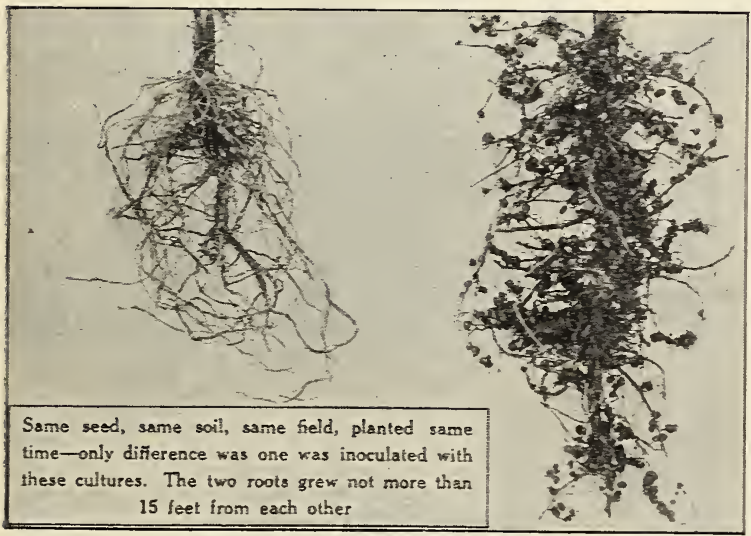

Prices for Clovers and Alfalfa

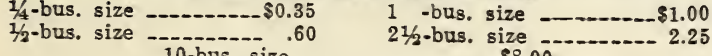

Means Better Soils Better Crops

\section{Less Fertilizer Expense}

Seeds of all legumes-Clorers, Alfalia, Sweet Clovers, Beans, Peas, Vetches, Soy Beans, Cowpeas, etc. - will sield far better results if inoculated with Stimugerm, and, in addition, leave in the soil a heavy deposit of nitrogen which benefits all succeeding crops in the rotation.

WHAT STIMLGERM WILL DO

Stimugerm will reduce your fertilizer bills, give you larger crops, and improve your soil by producing nodules on the roots of legumes, as shown in the illustration above. No other inoculant is as strong and virile. No other inoculant will give the profusion of nodules.

When ordering, be sure to state what crops you wish to inoculate.

Prices for Lespedeza, Soy Beans, Canada Field Peas and Vetch.

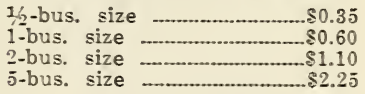

Special Garden Size for Garden Peas, Beans, and Sweet Peas, will inoculate $15 \mathrm{lbs}$. of seeds, $25 \mathrm{c}$.

\section{FLOWER BOXES AND STANDS}

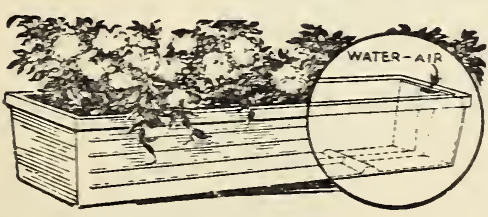

These FLOWER BOXES are made of coppered steel, coated with lead, which will not rust or deteriorate like galvanized iron. They have a patented self irrigating and air-circulating system. Finished in Old Ivory, Red or Green. All sizes are 6 inches deep and 7 inches wide.

\begin{tabular}{lll} 
& & \multicolumn{2}{c}{ Postpaid } & Not Prepaid \\
26 inches long & 1.70 & 1.50 \\
32 inches long & 2.20 & 2.00 \\
38 inches long & 2.75 & 2.50 \\
44 inches long & 3.25 & 3.00
\end{tabular}

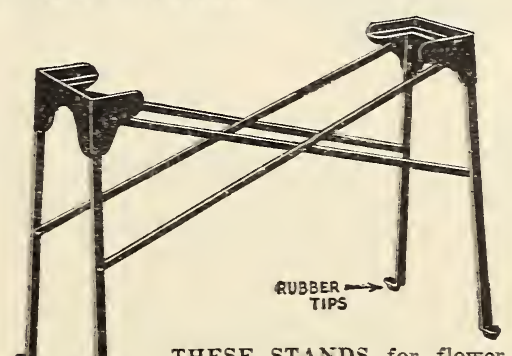

THESE STANDS for flower boxes are very strong and have rubber tips on legs to prevent scratching hardwood floors. They are shipped unassembled and go together with bolts furnished.

Postpaid Not Prepaid

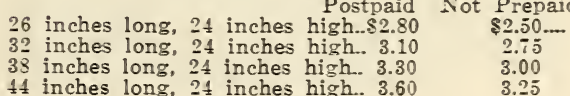




\section{CHEROKEE BRAND GRASS SEED}

\section{Timothy}

This most important perennial ranks unsurpassed as the hay producer of America. All livestock, especially horses, relish and thrive on it. Timothy prefers good stiff loamy soils containing an abundance of moisture, and is peculiarly adanted for the heavy clay soils of mountainous districts. It is a rapid grower, producing the best crop the first year. However, by manuring or topdressing with our special grass fertilizer the succeeding years may bring equally as good yields of this wonderful hay crop. Since it matures with Sapling Clover, Red Top, and Meadow Fescue, any or all of these are valuable additions both in production of larger yields of hay or grazing. If sown with Sapling Clover, the clover will help to supply nitrogen. 8 lbs. Timothy, and $6 \mathrm{lbs}$. Sapling Clover, to the acre.

A good pasture is $6 \mathrm{lbs}$. Timothy, $5 \mathrm{lbs}$. Red Top or Herds Grass, 7 lbs. Meadow Fescue and 5 lbs. Sapling Clover to the acre. Alone sow 12 to $15 \mathrm{lbs}$. to the acre. Postpaid, lb. $15 \mathrm{c} ; 2 \mathrm{lbs} .25 \mathrm{c}$; pk. $\$ 1.25$; $1 / 2$ bu. $\$ 2.45$; bu. (45 lbs.) $\$ 4.40$. Not prepaid (bags extra), about $\$ 3.65$ bu.

\section{Orchard Grass}

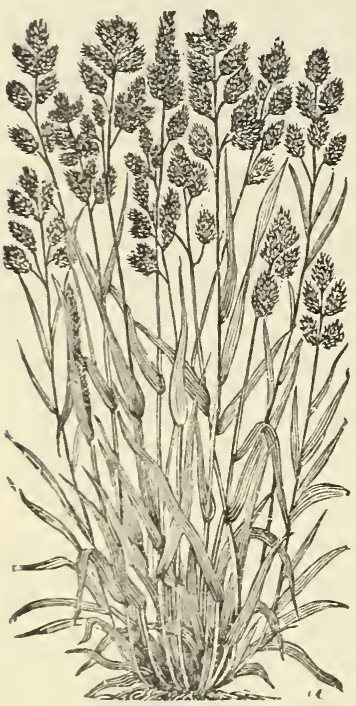

This deep rooted perennial grass is probably the best known and most universally used of all varieties of grass. It is very hardy and u c ceeds anywhere in the United States, yielding enormous crops of most nutritious hay for grazing. All livestock a re very fond of it, green or dry, and it endures con s t ant cropp in $g$ better than an $y$ other g $r$ a 8 8. It has been found that Orchard Grass is peculiarly adapted for growing in the shade, and that while it succeeds well on soils of sandy texture, the ideal soils are clay uplands or stiff soils. For finest quality hay it should be cut just before blossoming when the stem is less hard and the pitch of the stem is still soft and sweet. After bein $\%$ mown. Orchard Grass grows up quickly and yields a heavier aftermath than any other variety of grass. Since this variety grows in tufts, to obtain best results Red Clover or Tall Meadow Oat Grass, both of which mature at the same time, should be sown with Orchard Grass. The usual rate of seeding of such a mixture is 8 lb.s. Red Clover, $14 \mathrm{lbs}$. Orcharel Grass, and 11 lbs. Tall Meadow Oat Grass per acre, or $8 \mathrm{lbs}$. Red Clover and $21 \mathrm{lbs}$. of Orchard Grass per acre. Orchard frass sown alone requires 2 bushels per acre. For pastures, Red Top. Kentucky Blue Grass, Canada Blue Grass, Rye Grasses, and Clovers, are very desirable additions to Orchard Grass. Fertilizer applied in March or April at the rate of 300 to $400 \mathrm{lbs}$. to the acre increases the yield.

the ordinary sorts. Postnaid, lb. 65c; 5 lbs. \$2.75; 10 lbs. $\$ 5.30$. Not prepaid (bags included), lb. $55 \mathrm{c} ; 5$ lbs. $\$ 2.50 ; 10$ lbs. $\$ 4.90$.

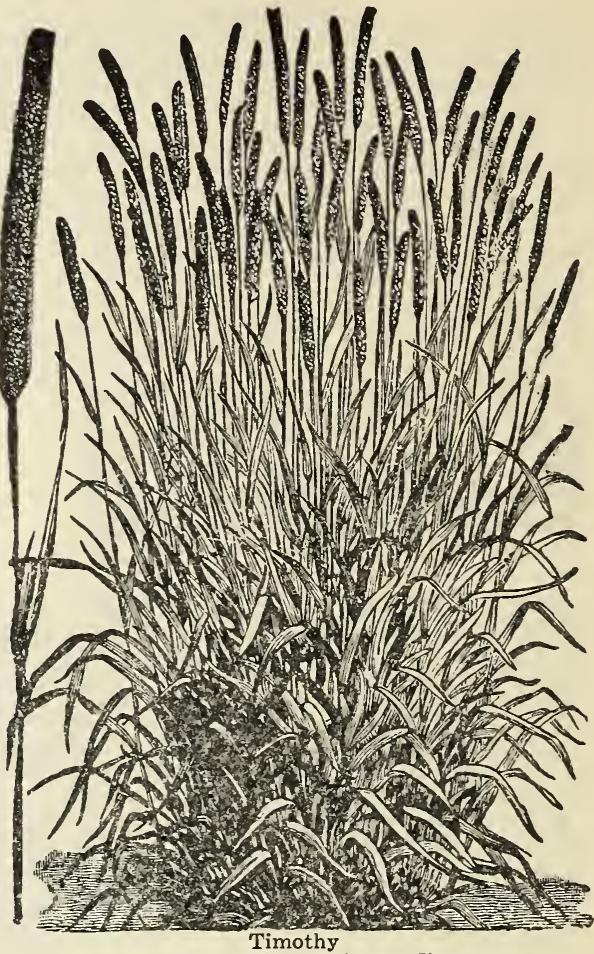

Tall Meadow Oat Grass

This perennial is most highly esteemed for pastures on account of its early and luxuriant growth of an abundant supply of foliage, which is greatly relished by cattle both during early spring and autumn. It is the first green grass of spring, and yields steady grazing until late fall, even during extreme drought or cold. For hay, two cuttings can be made each season, and for green feed four or five can be had under favorable conditions. It matures with Orchard Grass and Red Clover and mixed with these produces large yields of finest quality hay. All pasture mixtures should be composed of a percentage of this excellent year-round grazing crop. Sow 25 or $30 \mathrm{lbs}$. to the acre in spring or fall.

Sown with Orchard Grass and Red Clover, use 11 lbs. Tall Meadow Oat Grass, 14 lbs. Orchard Grass and $8 \mathrm{lbs}$. Red Clover to the acre.

Postpaid, lb. $30 \mathrm{c} ; 2$ lbs, $55 \mathrm{c} ; 1 / 2$ bu. $\$ 1.35$; bu. (11 lbs.) \$2.65. Not prepaid (bags included) bu. $\$ 2.25 ; 5$ bu. or over, $\$ 2.20$ bu.

\section{Bermuda Grass}

This is a most valuable grass for pasturage, hay, lawns, etc., in the lowlands of the South, where other grasses do not grow well due to the extreme heat. It stands hot weather remarkably well. We do not advise sowing it in the mountain section of Western North Carolina, except for hillsides and railway embankments, to keep them from washing. The seed should be sown broadcast 7 to $10 \mathrm{lbs}$. to acre from end of April to July Do not sow too early, as the seed will not germinate in cool weather. Cover seed lightly not more than half an inch. As this grass is very hard to eradicate it should not be used for temporary pasture. Our seed is Arlzona grown and forms a finer stem and grass than the ordinary sorts. Postpaid, lb. $65 \mathrm{c} ; 5$ lbs. $\$ 2.75$; $10 \mathrm{lbs}$. $\$ 5.30$ Not prepaid (bags included), lb. $55 \mathrm{c} ; 5$ lbs. $\$ 2.50 ; 10$ lbs. $\$ 4.90$. 


\section{CHEROKEE BRAND GRASS SEED-Continued}

\section{Red Top Or Herd's Grass}

A very hardy, native perennial grass well adapted for such a variety of situations that while succeeding best on moist lands, Red Top also flourishes in almost any soil and under all conditions, even withstanding hottest climates. Because it is perhaps our most permanent pasture grass every good hay and pasture mixture sown should contain a liberal quantity of this most excellent grass. It remains green for the greater part of the year, and its long trailing stems form a very close-matting turf that is not affected by trampling. Sow 10 or $12 \mathrm{lbs}$. to the acre.

Postpaid, lb. 35c; 2 lbs. 65c; 5 lbs. \$1.45; 10 lbs. $\$ 2.65 ; 25$ lbs. $\$ 5.65 ; 50$ lbs. $\$ 10.50$.

\section{Kentucky Blue Grass}

This true perennial combines more true points of excellence than any other grass. It is the most widely distributed of all native grasses. The densely creeping root stock, spreading habit and smooth even growth of fine texture and richest green color render Kentucky Blue Grass highly suitable for producing the rich velvety green turf so envied in all good lawns. It forms an early close turf in almost any soil, dry, rocky, sandy or gravelly, and withstands dry weather admirably. It takes several years to establish a heavy sod, and should, therefore, be sown with other grasses. Soils of Western North Carolina should be heavily limed before sowing lawns of Blue Grass. It is also most valuable for pastures because of its productiveness and the wonderful nourishing qualities of the green food. Sow 25 to $30 \mathrm{lbs}$. per acre for pasture and 75 to 100 lbs. per acre for lawns.

Postpaid, lb. 50c; 2 lbs. 95c; 5 lbs. \$2.20; 10 lbs. $\$ 4.15 ; 25$ lbs. $\$ 9.65 ; 50$ lbs. $\$ 18.50$.

\section{Meadow Fescue Or Randall Grass}

One of the grasses most used in permanent or temporary meadows for mowing or pasture as it remains green all winter. It succeeds best in cold, moist, light soils, in well-drained meadows and low valleys rich in organic matter. It reaches full development the second or third year, and then far exceeds most grasses in productiveness of a very superior feed, dry or green. After being mown, it grows up quickly. It is highly relished

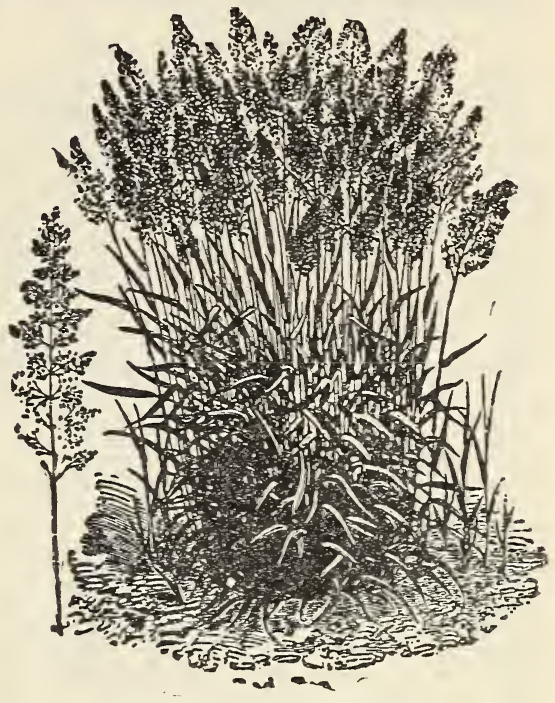

Red Top or Herd's Grass

Perennial Or English Rye Grass

An early maturing, quick growing grass, making fine grazing and hay. Excellent mixed with other grasses, furnishing valuable permanent pasture and hay. It is also being largely sown in lawns. When sown alone, sow $30 \mathrm{lbs}$. to an acre. Postpaid, lb. $35 \mathrm{c} ; 2$ lbs. 65c; 5 lbs. \$1.35; 10 lbs. $\$ 2.50$.

\section{Italian Rye Grass}

This grass resembles English Rye Grass considerably, but is not recommended for lawns or golf courses. It is a very valuable, vigorous growing grass, suitable for furnishing in a very short time a splendid green pasture. It forms a good turf, and stands the dry weather remark$y$ spring. ft. high. ic ; $5 \mathrm{lbs}$. c: 5 lbs.

\section{THE PRICE OF ORCHARD GRASS SHOULD BE}

Postpaid lb. 30c; 2 lbs. 55c; 1/2 bu. $\$ 1.70$; bu. (14 lbs.) \$3.15.

Not prepaid (bags included), bu. $\$ 2.75 ; 8$ bu. or over $\$ 2.65$ bu.

d thrives fail. Is no heat. ly, yield1. It is 3 on acgrowth. tana, out is well adapted for almost any soil. The roots penetrate deeply into the ground. which enables it to withstand severe drought. It is extremely valuable both for lawns and pastures as a bottom grass, and thrives well in the shade. It is sown at the rate of 30 lbs. per aere alone, but recommended only for use in mixtures.

Postpaid, lb. $85 \mathrm{c} ; 2$ lbs. $\$ 1.60 ; 5$ lbs. $\$ 3.85$; 10 lbs. $\$ 7.50$.

\section{Creeping Bent Grass}

This is a most valuable grass for lawns and putting greens. It is of rapid growth and spreading habit, and the stoloniferous roots which penetrate deep into the soil form a strong enduring turf that is actually improved by constant trampling. Creeping Bent is a grass of fine texture. Postpaid-Lb. $\$ 1.10 ; 2$ lbs. $\$ 2.00 ; 5$ lbs. $\$ 4.70$; 10 lbs. $\$ 8.85$. 


\section{CHEROKEE BRAND GRASS SEED}

\section{Timothy}

This most important perennial ranks unsurpassed as the hay producer of America. All livestock, especially horses, relish and thrive on it. Timothy prefers good stiff loamy soils containing an abundance of moisture, and is peculiarly adanted for the heavy clay soils of mountainous districts. It is a rapid grower, producing the best crop the first year. However, by manuring or topdressing with our special grass fertilizer the succeeding years may bring equally as good yields of this wonderful hay crop. Since it matures with Sapling Clover, Red Top, and Meadow Fescue, any or all of these are valuable additions both in production of larger yields of hay or grazing. If sown with Sapling Clover, the clover will help to supply nitrogen. 8 lbs. Timothy, and $6 \mathrm{lbs}$. Sapling Clover, to the acre.

A good pasture is $6 \mathrm{lbs}$. Timothy, $5 \mathrm{lbs}$. Red Top or Herds Grass, 7 lbs. Meadow Fescue and 5 lbs. Sapling Clover to the acre. Alone sow 12 to 15 lbs. to the acre. Postpaid, lb. $15 \mathrm{c} ; 2$ lbs. $25 \mathrm{c}$. pk. $\$ 1.25$; $1 / 2$ bu. $\$ 2.45$; bu. (45 lbs.) $\$ 4.40$. Not prepaid (bags extra), about $\$ 3.65 \mathrm{bu}$.

\section{Orchard Grass}

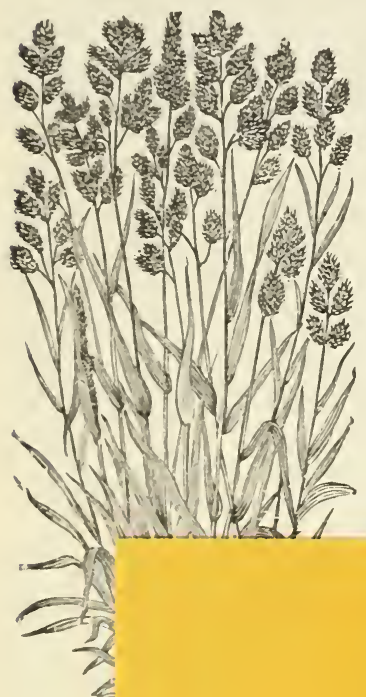

This deep rooted perennial grass is probably the best known and most universally used of all varieties of grass. It is very hardy and $s$ u c e e d s anywhere in the United States, yielding e normou crops of most nutritious hay for grazing. All livestock a $\mathrm{re}$ very fond of it, green or dry, and it endures con s t ant cropp in $\mathrm{g}$ better than a $n y$ other g r a 8 . It has been found that Orchard Grass is peculiarly adapt-

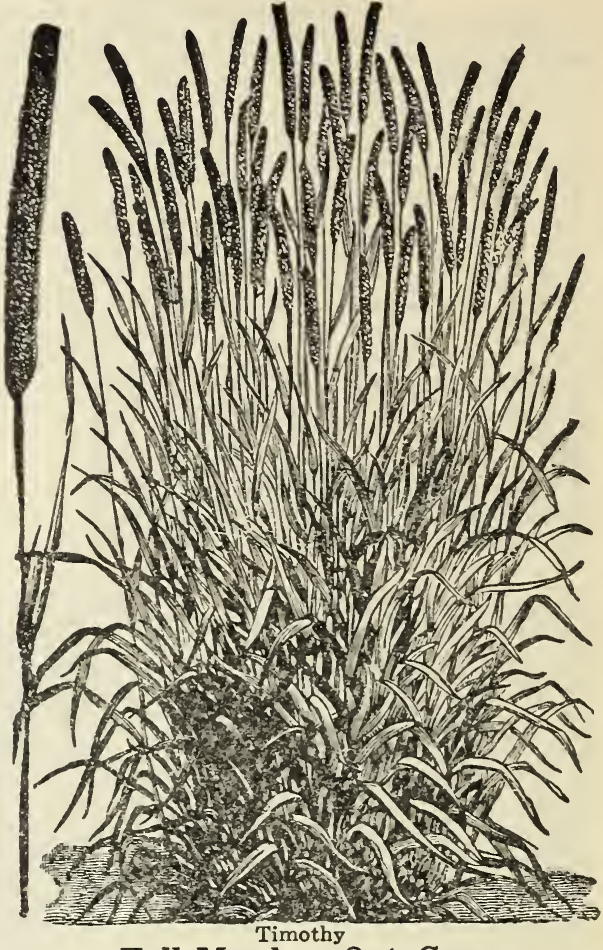

Tall Meadow Oat Grass

This nerennial is most highly esteemed for pastures on account of its early and luxuriant growth of an abundant supply of foliage, which is greatly relished by cattle both during early spring and autumn. It is the first green grass of spring, and yields steady grazing until late fall, even during extreme drought or cold. For hay, two cuttings can be made each season, and for green feed four

should bi

stem is 10

soft and

grows ur

than any

ety grow

Clover or

mature a:

chard $\mathrm{Gr}$ :

mixture

Grass, and 11 lbs. Tall Meadow Oat Grass per acre, or $8 \mathrm{lbs}$. Red Clover and $21 \mathrm{lbs}$, of Orchard Grass per acre. Orchard Grass sown alone requires 2 bushels per acre. For pastures, Red Ton. Kentucky Blue Grass, Canada Blue Grass, Rye Grasses, and Clovers, are very desirable additions to Orchard Grass. Fertilizer applied in March or April at the rate of 300 to 400 lbs. to the acre increases the yield.

the ordinary sorts. Postpaid, lb. 65c; 5 lbs. $\$ 2.75$; 10 lbs. $\$ 5.30$. Not prepaid (bags included), lb. $55 \mathrm{c} ; 5$ lbs. $\$ 2.50 ; 10$ lbs. $\$ 4.90$.

except for hillsides and railway embankments, to keep them from washing. The seed should be sown broadcast 7 to 10 lbs. to acre from end of April to July Do not sow too early, as the seed will not germinate in cool weather. Cover seed lightly not more than half an inch. As this grass is very hard to eradicate it should not be used for temporary pasture. Our seed is Arizona grown and forms a finer stem and grass than the ordinary sorts. Postpaid, lb. 65c; 5 lbs. $\$ 2.75$; 10 lbs. $\$ 5.30$. Not prepaid (bags included), lb. $55 \mathrm{c} ; 5$ lbs. $\$ 2.50 ; 10$ lbs. $\$ 4.90$. 


\section{CHEROKEE BRAND GRASS SEED-Continued}

\section{Red Top Or Herd's Grass}

A very hardy, native perennial grass well adapted for such a variety of situations that while succeeding best on moist lands, Red Top also flourishes in almost any soil and under all conditions, even withstanding hottest climates. Because it is perhaps our most permanent pasture grass every good hay and pasture mixture sown should contain a liberal quantity of this most excellent grass. It remains green for the greater part of the year, and its long trailing stems form a very close-matting turf that is not affected by trampling. Sow 10 or $12 \mathrm{lbs}$. to the acre.

Postpaid, lb. 35c; 2 lbs. 65c; 5 lbs. $\$ 1.45$; 10 lbs. $\$ 2.65 ; 25$ lbs. $\$ 5.65 ; 50$ lbs. $\$ 10.50$.

\section{Kentucky Blue Grass}

This true perennial combines more true points of excellence than any other grass. It is the most widely distributed of all native grasses. The densely creeping root stock, spreading habit and smooth even growth of fine texture and richest green color render Kentucky Blue Grass highly suitable for producing the rich velvety green turf so envied in all good lawns. It forms an early close turf in almost any soil, dry, rocky, sandy or gravelly, and withstands dry weather admirably. It takes several years to establish a heavy sod, and should, therefore, be sown with other grasses. Soils of Western North Carolina should be heavily limed before sowing lawns of Blue Grass. It is also most valuable for pastures because of its productiveness and the wonderful nourishing qualities of the green food. Sow 25 to $30 \mathrm{lbs}$. per acre for pasture and 75 to 100 lbs. per acre for lawns.

Postpaid, lb. 50c; 2 lbs. 95c; 5 lbs. $\$ 2.20$; 10 lbs. $\$ 4.15 ; 25$ lbs. $\$ 9.65 ; 50$ lbs. $\$ 18.50$.

\section{Meadow Fescue Or Randall Grass}

One of the grasses most used in permanent or temporary meadows for mowing or pasture as it remains green all winter. It succeeds best in cold moist, light soils, in well-drained meadows and low valleys rich in organic matter. It reaches full development the second or third year, and then far exceeds most grasses in productiveness of a very superior feed, dry or green. After being mown, it grows up quickly. It is highly relished by cattle and is most nourishing. Sow 30 to $40 \mathrm{lbs}$. to the acre.

Postpaid, lb. 45c; 2 lbs. 80c; 5 lbs.\$1.85; 10 lbs. $\$ 3.50$.

\section{Red Or Creeping Fescue}

A creeping-rooted species forming a close and lasting turf, especially adapted for dry and sandy soils. Thrives on poor soils, gravelly banks and exposed hillsides. Valuable for shady places in lawns and golf courses. Sow $30 \mathrm{lbs}$ per acre.

Postpaid, lb. 60c; 2 lbs. $\$ 1.10 ; 5$ lbs, $\$ 2.50$; 10 lbs. $\$ 4.75$.

\section{Crested Dogstail}

A true perennial, forming a smooth compact and lasting turf. It thrives best on rich, moist land, but is well adapted for almost any soil. The roots penetrate deeply into the ground which enables it to withstand severe drought. It is extremely valuable both for lawns and pastures as a bottom grass, and thrires well in the shade. It is sown at the rate of 30 lbs. per acre alone, but recommended only for use in mixtures.

Postpaid, lb. $85 \mathrm{c} ; 2$ lbs. $\$ 1.60 ; 5$ lbs. $\$ 3.85$; 10 lbs. $\$ 7.50$

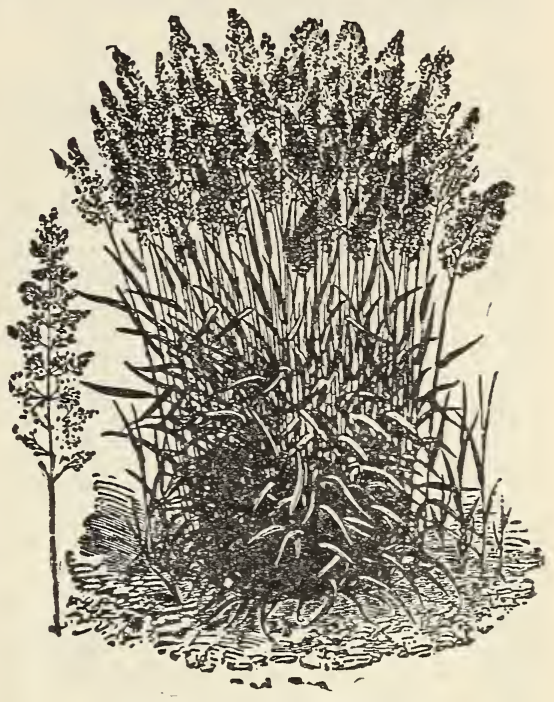

Red Top or Herd's Grass

Perennial Or English Rye Grass

An early maturing, quick growing grass, making fine grazing and hay. Excellent mixed with other grasses, furnishing valuable permanent pasture and hay. It is also being largely sown in lawns. When sown alone, sow $30 \mathrm{lbs}$. to an acre. Postpaid, lb. 35c; 2 lbs. 65c; 5 lbs. \$1.35; 10 lbs. $\$ 2.50$.

\section{Italian Rye Grass}

This grass resembles English Rye Grass considerably, but is not recommended for lawns or golf courses. It is a very valuable, vigorous growing grass, suitable for furnishing in a very short time a splendid green pasture. It forms a good turf, and stands the dry weather remarkably well. This grass can be sown with success either in the fall of the year or very early spring. On rich land it will grow from 2 to $3 \mathrm{ft}$. high.

When sown alone use $30 \mathrm{lbs}$. to the acre.

Imported. Postpaid, lb. 35c; 2 lbs. $65 \mathrm{c}$; $5 \mathrm{lbs}$. $\$ 1.35 ; 10$ lbs. $\$ 2.50$.

Domestic. Postpaid, lb. $25 \mathrm{c} ; 2$ lbs. $45 \mathrm{c} ; 5$ lbs. $80 \mathrm{c} ; 10$ lbs. $\$ 1.50$

\section{Sheep's Fescue}

Sheep's Fescue prefers dry uplands and thrives in poor shallow soils when other grasses fail. Is is very hardy, resisting cold or extreme heat. Although of dwarf habit, it grows thickly, yielding large quantities of nutritious feed. It is largely used on lawns and golf courses on account of its fine foliage and dense dwarf growth. Sow 30 ibs. per acre. Postpaid, lb. 60c: 2 lbs. $\$ 1.10 ; 5$ lbs. $\$ 2.50 ; 10$ lbs. $\$ 4.75$.

\section{Creeping Bent Grass}

This is a most valuable grass for lawns and putting greens. It is of rapid growth and spreading habit, and the stoloniferous roots which penetrate deep into the soil form a strong enduring turf that is actually improved by constant tramp ling. Creeping Bent is a grass of fine texture. Postpaid-Lb. $\$ 1.10 ; 2$ lbs. $\$ 2.00 ; 5$ lbs. $\$ 4.70$ 10 lbs. $\$ 8.85$. 


\section{CHEROKEE BRAND GRASS SEED-Continued}

\section{Sudan Grass}

This grass is an annual belonging to the Sorghum family. The first seed was secured from Khartum, Sudan, in 1909. When planted in rows and cultivated in fairly rich soil it grows to a height of 7 to 9 feet and has stems $1 / 4$ in. in diameter. Broadcasted it rarely exceeds 3 to 5 feet in height and the stems are much finer in diameter. Sudan Grass is not particular about the soil but it does best in fairly rich clay loam. Belonging to the Sorghum family, it has a short growing season, maturing for hay from about 75 to 80 days. This yuality allows for its use as a catch crop. Should not be planted until the soil has become wal'm in the spring. Sudan Grass is easy to cut cures readily and yields from 2 to 4 tons of cured hay per acre. It is best to cut just after full bloom, so that it will have as much time as possible for the second growth. After cutting it renews its growth promptly and in about 40 to 50 days another cutting is ready. Sudan Grass makes a very nutritious and palatable hay which is greatly relished by both cattle and horses. Can be sown in drills or broadcast. When in drills about $2 \mathrm{ft}$. apart, it requires about $10 \mathrm{lbs}$. of seed to an acre. If broadcast or drilled thickly, 20 to 25 lbs. to an acre is required. Sudan Grass with Soy Beans produces a good yield of well balanced forage. Broadcast 50 lbs. Soy Beans with $10 \mathrm{lbs}$. Sudan. Cut for hay about time Soy Beans are nearly full grown. Postpaid, lb. $25 \mathrm{c} ; 2$ lbs. $45 \mathrm{c}$; 5 lbs. $90 \mathrm{c} ; 10$ lbs. $\$ 1.55$; 25 lbs. $\$ 3.00$; 50 lbs. $\$ 5.50$. Not prepaid (bags included), lb. $15 \mathrm{c}$; 2 lbs. $30 \mathrm{c} ; 5$ lbs. $65 \mathrm{c}$; $10 \mathrm{lbs}$. $\$ 1.20 ; 25$ lbs. $\$ 2.50$; 50 lbs. $\$ 4.50 ; 100$ lbs. $\$ 8.00$.

\section{Rough Stalked Meadow Grass}

A spreading, thickly matted, stoloniferousrooted species, forming a fine turf and adapted for shaded portions of lawns. It thrives on rich, moist soil and in sheltered situations, but not on dry land. Valuable for forming bottom grass in mixtures for permanent pastures. Sow $20 \mathrm{lbs}$. to the acre. Postpaid, lb. 70c; 2 lbs. $\$ 1.35$ 5 lbs. $\$ 3.25 ; 10$ lbs. $\$ 6.00$.

\section{Cyclone Seed Sower}

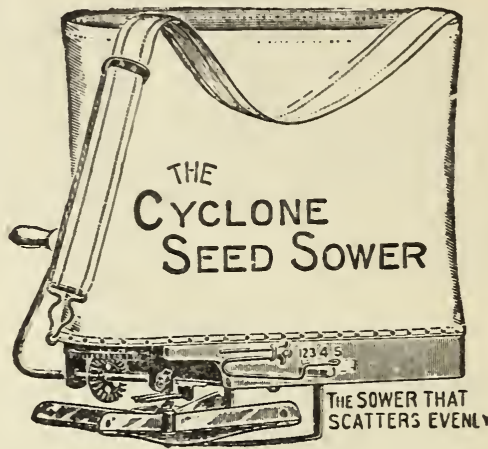

This sower is guaranteed to distribute seed perfectly and evenly, will not throw seed in an upward direction or against the operator, but direct and evenly to the land; sows clover, timcthy, red top or herd's grass, oats, millets, sorghum cane, rye, wheat, buckwheat, turnip and other seeds that are sown broadcast. Time and money can be saved by the use of this sower. Price, $\$ 2.00$ each. Postpaid, \$2.15.

\section{Wood Meadow Grass}

This grass is especially fitted for shaded positions in the lawns and woodland parks, where other grasses will not grow. Very permanent and hardy, resisting extremes of heat and cold. One of the first grasses to show a rich growth in the spring. Creeping roots are formed under ground, and make a good turf. Excellent for pasture. Sow 30 lbs, to acre. Wood Meadow Grass is used in our Shady Park Mixture.

Postpaid, lb. $70 \mathrm{c} ; 2$ lbs. $\$ 1.35$; 5 lbs. $\$ 3.25$; 10 lbs. $\$ 6.00$.

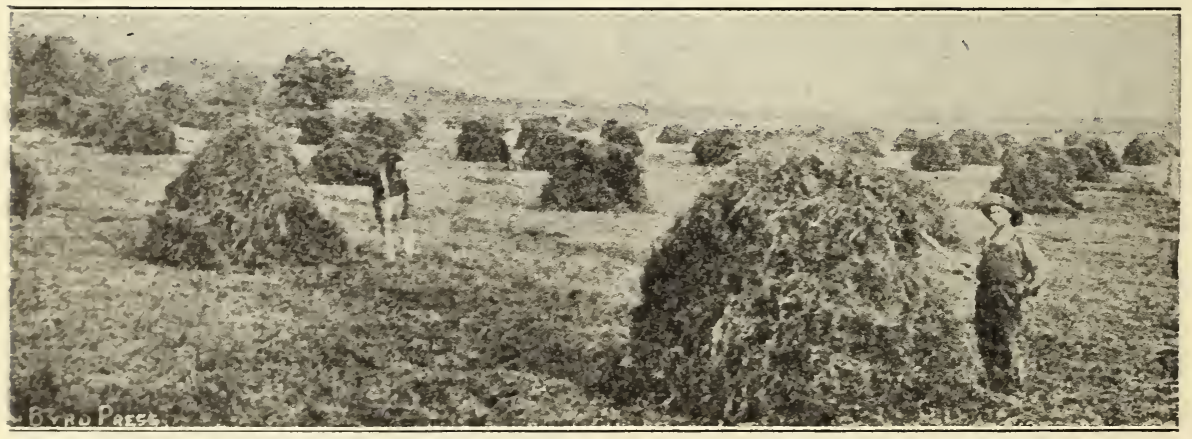

\section{Cherokee Pasture and Hay Mixture}

It has been proven conclusively that many kinds of grass and clover seeds mixed together in proper proportion will produce on any soil a much larger yield and a more nutritious crop. It will give more cuttings and a longer period of grazing. Where a single grass is sown there will be vacant places that will fill un with weeds, while in a mixture there is seed adapted to all soils and as a result the whole surface will be covered with good grasses. Each and every variety of grass has its peculiar characteristics, some will withstand extreme drought, some are early and some are late and as a result a well-balanced mixture will give a green pasture under all conditions.

Our "CHEROKEE PASTURE MIXTURE" for upland and lowland is a mixture best adapted to the soils of Western North Carolina, and many of our customers that bought at first in small quantities are now sending in large repeat orders. The mixtures are giving the greatest satisfaction. When ordering, please state whether for upland or lowland. Sow 25 to $30 \mathrm{lbs}$. to the acre.

Postpaid, lb. $45 \mathrm{c} ; 2$ lbs. $80 \mathrm{c} ; 5$ lbs. $\$ 1.75 ; 10$ lbs. $\$ 3.25 ; 25$ lbs. $\$ 7.50 ; 50$ lbs. $\$ 14.00$. 


\section{MISCELLANEOUS AND FORAGE CROPS}

\section{Buckwheat}

Buckwheat will make a crop quicker than any other grain, does well on any land but it is especially adapted to poor land. It is easy to grow and a good soil improver. When turned under it is fine to smother out weeds. Largely grown for bees, greatly increasing the production of honey. Should not be sown until eight or ten weeks before frost, as the grains will not form in hot weather. Sow one bushel to the acre.

JAPANESE-The earliest and most prolific of all buckwheat, makes the largest grain, and makes fine flour.

Postpaid, lb. 20c; 2 lbs. $30 \mathrm{c} ; 1 / 2$ pk. $60 \mathrm{c}$; pk. $\$ 1.00$; bu. (48 lbs.) $\$ 3.25$.

\section{Barley (Beardless)}

Beardless Barley makes a bigger yield and is taller, larger and stiffer than the bearded variety. Being beardless it is easily handled, and can be fed to stock without danger, same as oats; cattle are very fond of the hay; heads are sixrowed; hulls remain tight after being cut; long heads; ripens 60 to 90 days. Can be sown in Aurust and cut in October. For spring sow in February and March and cut in June. Sow 146 to 2 bu. to the acre.

Postpaid, lb. 20c; 2 lbs. 30c; $1 / 2$ pk. 60c; pk. $\$ 1.00$; bu. (48 lbs.) $\$ 3.25$.

\section{Mangel-Wurtzel or Stock Beets}

A splendid winter feed for cattle and hogs. Increases the milk flow. Yield larger crops than turnips, and are higher in feeding value. Plant in the spring in drills two to two and one-half feet apart, covering with one inch of soil firmly pressed down. Cultivate frequently. When about three inches high, thin out until the plants stand about ten inches apart. One ounce sows $50 \mathrm{ft}$. of drill. Sow 6 to 8 pounds to an acre.

MAMMOTH LONG RED (NORBITON GIANT) - The best for stock feeding as it containg the most nutritive value The part of the beet above sround is red or rose colored and the part below ground is white. The flesh is white, tinged red or rose color. The roots grow very large and straight. Very productive and a good keeper.

Postpaid, oz, 10c; 1/4 lb, 20c; lb, 60c

Not prepaid, $1 \mathrm{~b} .50 \mathrm{c} ; 5 \mathrm{lbs}$. and over, $40 \mathrm{c}$ per $\mathrm{lb}$.

GOLDEN TANKARD-The best known and most largely grown yellow mangel. Roots large, nearly cylindrical in shape, narrowing abruptly at both ends; skin deep orange yellow; flesh zoned yellow and white; sweet and productive; light gray above the ground, deep orange below. Especially recommended for dairymen on account of its wonderful milk producing properties.

Postpaid, oz., 10c; $1 / 4$ lb., 20c; lb., 60c.

Not prepaid, $1 \mathrm{~b} .50 \mathrm{c} ; 5 \mathrm{lbs}$. and over, $40 \mathrm{c}$ per $1 \mathrm{~b}$.

\section{Canada Field Peas}

Canada Field Peas make a fattening and milk producing food that will grow on land that will not produce a grain crop, and at the same time improve the soil by gathering and storing nitrogen. In this respect it is almost equal to the clovers. They yield heavy crops that may be either grazed or made into hay that stock eat sreedily and thrive on. Vines grow 4 to 5 feet high, but can be grazed when 6 to 10 inches high If not grazed too closely, a second growth may be had. Pasturing the peas makes them stool out better and results in a finer growth of vine and 3 better hay. Sow as soon as the ground can be Forked. Sow one bushel to the acre and plow in 4 inches deep and then drill in one bushel Oat to the acre to hold the vines off the ground. If own alone use 11/2 bushels to the acre. Inoculate the Peas with Stimugerm.

Postpaid, Gal. 85c; pk. $\$ 1.50$; I/2 bu. $\$ 2.75$; bu. (60 lbs.) $\$ 5.00$.

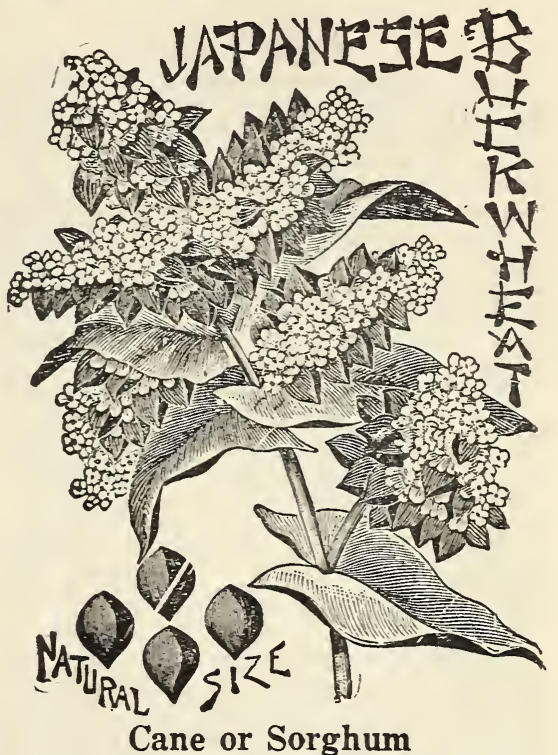

Is used for forage and making sorghum. One of the very best crops for dairy cattle that can be grown, giving bigger yields per acre than any other forage crop. Plant when the ground becomes thoroughly warm on a well drained clay loam in rows $3 \frac{1}{2}$ feet apart or sow broadcast.

In drills use 5 to 8 lbs. to the acre. Broadcast sow 50 to $70 \mathrm{lbs}$. to the acre. Cultivate as you would corn. After the flowering stage is passed, but not earlier, it may be pastured or cut for fodder. Cane may be grown with cow peas and soy beans.

EARLY AMBER-Produces a large yield of nutritious hay; grows 10 to $12 \mathrm{ft}$. high, has excellent stooling tendencies; can be cut twice for hay if planted early. An excellent green or cured feed.

Postpaid; Gal. 60c; pk. $\$ 1.05$; 1/2 bu. $\$ 1.90$; bu. (50 lbs.) $\$ 3.40$.

EARLY ORANGE-Considering by many to be the best yielder of all the cane forage crops; produces large stalks. About 10 days later than Amber. May be used for syrup.

Postpaid; Gal. 60c; pk. $\$ 1.05$; $1 / 2$ bu. $\$ 1.90$; bu. (50 lbs.) $\$ 3.40$.

\section{Broom Corn, Improved Evergreen}

This is the best variety for making brooms; is tall and straight with fine green color when cured. Plant 6 to 8 lbs. to an acre, 1 inch deep in $81 / 6$ foot rows, thinning out to 8 to 10 inches apart in the rows. Cultivate early and often and harvest when seed becomes soft and milky. Postpaid, lb. $30 \mathrm{c} ; 2$ lbs. $50 \mathrm{c}$ : 5 lbs. $\$ 1.10 ; 10$ lbs. $\$ 1.85$. Not prepaid (bags included), 1b. 20c; 5 lbs. $85 \mathrm{c}$; $10 \mathrm{lbs}$. $\$ 1.60$.

\section{Millet}

TENNESSEE GROWN CULTIVATED GOLD. EN MILLET-Millet furnishes food for live stock in the form of grain, fodder and pasture. Sow one bushel broadcast to the acre from the middle of May through July. Makes the best hay if cut in blossom and carefully cured. Can be used with Cow Peas, sowing 3 pecks of Millet and $1 \mathrm{bu}$. of Cow Peas to the acre.

Postpaid, ib. $20 \mathrm{c} ; 2$ lbs. $30 \mathrm{c}$; $1 / 2$ pk. $70 \mathrm{c}$ : pk. $\$ 1.10$; $1 / 2$ bu. $\$ 2.00$; bu. (50 lbs.) $\$ 3.65$. 


\section{MISCELLANEOUS AND FORAGE CROPS}

\section{Seed Oats}

The spring varieties of Oats are planted from February to April and the fall varieties from September to November. Usually 2 to $3 \mathrm{bu}$. are sown broadcast to the acre. Drilling requires 116 to $2 \mathrm{bu}$. to the acre.

Write for prices in larger quantities than quoted.

BURT OR NINETY-DAY-This is the quickest growing, most prolific, and surest cropping of all spring oats. It is a sure header, early maturing (about two weeks earlier than other varieties) and is rustproof. The healthy, clean and vigorous growth produces an abundant yield of bright, heavy grain. Burt Oats are especially adapted for poor soils.

Postpaid, pk. 60c ; $1 / 2$ bu. $95 \mathrm{c}$; bu. (32 lbs.) $\$ 1.60$.

RED RUSTPROOF-They are vigorous growers, robust and productive, and have heavy heads. They are also preferred for sowing in the spring on low grounds and on land where other varieties seem inclined to rust.

Postpaid, pk. 60c; I/s bu. $95 \mathrm{c}$; bu. ( $32 \mathrm{lbs}$ ) $\$ 1.60$

WHITE SPRING-A very popular variety in Western North Carolina. It is an excellent yielder of bright, clean grain ; is extremely hardy and grows taller than other varieties.

Postpaid, pk. 60c; $1 / 2$ bu. $95 \mathrm{c}$; bu. ( 32 lbs.) $\$ 1.60$

WINTER TURF-The wide popularity of Winter Turf Oats is probably due to their hardiness, eince there is no other variety that can withstand such extreme cold. Experiments in practically all climates prove that these Oats seldom winter kill. It has remarkable stooling tendencies and is a heavy yielder of bright grain which very often weighs 35 to $40 \mathrm{lbs}$. per bushel.

Sow from September till November, or early in the spring. Postpaid, pk. $70 \mathrm{c}$; $1 / 2$ bu. $\$ 1.10$; bu. (32 lbs.) $\$ 1.90$.

FULGHUM-The Fulghum is probably the most popular of the rust-proof winter varieties. Its productiveness, probably more than any of its other good qualities, has contributed to the wide popularity it has attained. They stool out splendidly, have large, full heads, fine, plump grains and strong straw that stands about 3 feet high. the length of the straw is well worth considering if the oats are to be cut for hay. Sow from September till November or early in the spring.

Postpaid, pk. 60c; $1 / 2$ bu. $95 \mathrm{c}$; bu. $\$ 1.60$.

\section{Seed Rye}

Rye is a good crop to grow whether wanted for grain, for grazing, for green feed, for turning under to improve the condition of the soil, or for growing as a cover crop to prevent winter leaching of plant food from the land. It will thrive on a greater variety of soils than wheat, does well in dry seasons and on lands too poor to produce a profitable crop of wheat. For feeding green rye will furnish green food earlier in the spring than most other forage plants.

Sow $11 / 2$ bu. to the acre broadcast any time from July to December before freezing weather sets in. On poor land sow early. For grazing crop, we suggest sowing with Hairy or Winter Vetch. 25 to 30 lbs. of Vetch with one bushel of Rye (56 lbs.) to the acre. Inoculate the Vetch with Stimugerm.

MOUNTAIN RYE-This rye is much hardier than other varieties and withstands the severest winters without injury. For this reason and because it is acclimatized we recommend it above all other ryes for use in this section. Ask for prices about the first of July.

ABRUZZI RYE-The best rye for light lands. Gives a quick, vigorous growth with large wellflled heads. Matures earlier than Mountain rye. Ask for prices about July 1st.

\section{seed Wheat}

Wheat is sown in this section during the months of October and November at the rate of 5 pecks to the acre. We stock both the slick and bearded varieties. For smut use $1 \mathrm{lb}$. copper sulphate to 20 gals, water.

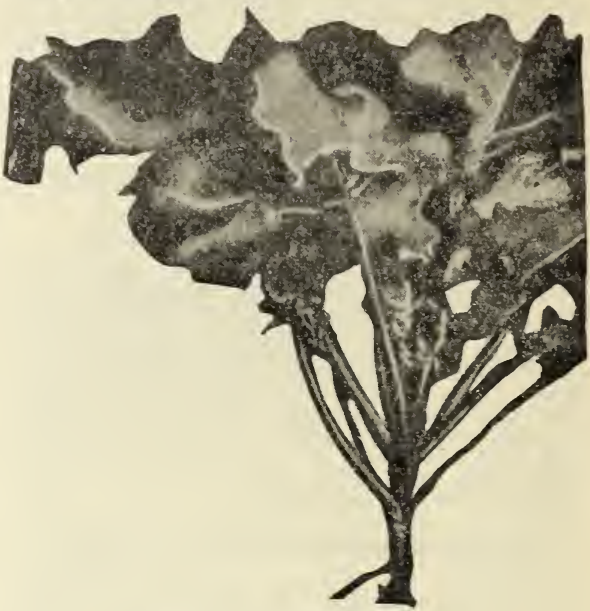

\section{Rape-Dwarf Essex}

Rape is possibly the cheapest of all forage crops to produce. Requires only eight pounds of seed to the acre and practically the same seed bed preparation as corn. Unlike corn and many other crops, Rape requires no cultivation from the time it is seeded until it is ready to pasture. It is ready to pasture in about sixty days after seeding, one acre affording excellent forage for ten to fifteen hogs or sheep. Rape can be sown alone or in combination with other grain and grass crops. Rape sown in combination with oats makes excellent forage the oats being drilled in at the rate of one bushel per acre and the rape seed sown broadcast at the rate of five to six pounds per acre. Another good combination and one possibly used more extensively than all others is RAPE SEED, OATS and RED CLOVER. Rape Seed five to six pounds per acre, oats one bushel and Red Clover eight pounds per acre. Red Clover and Rape sown broadcast and the Oats drilled in. Forage crops such as Rape seed are especially desirable land coverings for the winter months when the soil is subject to washing, the firmly rooted plants adding stability to the soil as well as producing considerable revenue from land that would otherwise stand idle throughout the winter months.

Rape is practically a year-round crop. With successive planting, Rape forage can be obtained for almost twelve months of the year. Seeding can be done from April to October, and usually as late as the last of November. Forage will be ready in late spring, growing luxuriantly throughout summer, fall and winter months and up until early spring. Rape can be sown to good advantage at the last plowing of corn, following oats or wheat and other summer crops. Idle acres can be made to produce liberally during the winter months when no other crops are being grown and the crop pastured until spring when the land can be used for other purposes. Rape or the combinations mentioned above furnish splendid green feed for chickens very economically.

Postnaid, lb. 30c; 2 lbs. 50c; 5 lbs. $\$ 1.00$

Write for prices in larger quantities. 


\section{MISCELLANEOUS AND FORAGE CROPS}

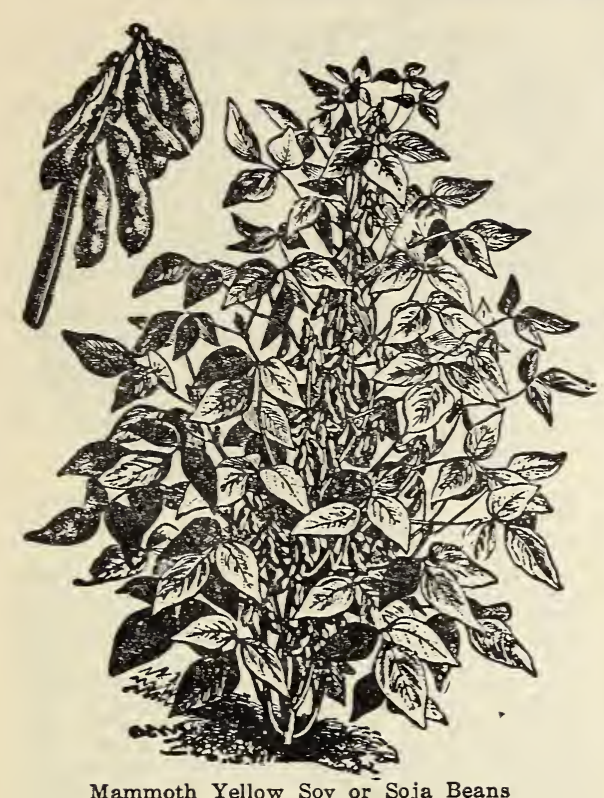

Mammoth Yellow Soy or Soja Beans

\section{Cow Peas}

Cow-Peas make one of the largest yielding and most nutritious forage crops known. There is also no surer or cheaper means of improving and increasing the productiveness of the soil.

Cow Peas can be grown on any soil that is not too wet and do not require expensive fertilizer and improve the conditions of the soil by adding nitrogen to it, but a top dressing of $16 \%$ Acid will increase the yield and improve soil conditions still further. Inoculating seed with Stimugerm will further increase the nitrogen gathering qualities of the peas and insure a still more abundant yield. Plant about 2 inches deep.

Alone sow $1 \frac{1}{2}$ bu. to the acre in May, June and July. To enable the vines to be cut and harvested to better advantage, one bushel of peas should be sown with $1 / 2$ bushel of Soy Beans or with one peck of cane. For a hay crop, one bushel can be sown with three pecks of millet to the acre.

WHIPPOORWILL-Is more largely grown than any other named variety, probably because of its long vine, usually six feet long, and because of its large yield of both hay and peas. It matures early, makes an upright growth, making it easy to cut. Has brown speckled seeds that are easily threshed. Ask for prices the last of April.

BRABHAM-The seeds are similar in appearance to Whippoorwill, but smaller, and do not require to be seeded as thickly as other kinds. Is particularly valuable where it is desired to cure for hay. One of the best varieties for very poor land. Ask for prices the last of April.

CLAY-One of the medium late varieties. Vigorous growth of vine and running habit. A good variety for soil-improving and very popular in all the Southern states. Ask for prices the last of April.

MIXED COW PEAS-Preferred by many farmers where the crop is intended for soil improving; they will grow thicker than separate varieties, producing better crop of vines and forage. Ask for prices the last of April.

\section{Soy or Soja Beans}

Soy Beans have a higher feeding value than Cow Peas and stock seem to like the hay better. As a milk and butter producer, Soy Beans are equal to alfalfa and are considered superior to cotton seed meal and corn; makes an excellent winter feed for young cattle, sheep and horses when fed with roughage. Can be sown either broadcast at the rate of 1 to $11 / 2$ bushels to the acre or in drills about a peck to the acre. Plant in May or June, not over 2 inches deep.

Soy Beans can be grown with other crops, yielding a larger crop of forage, $1 / 2$ bushel soy beans to one bushel of cow peas to the acre, or one bushel of soy beans with a peck of cane, make a good combination. 10 lbs. of Sudan Grass with $50 \mathrm{lbs}$. soy beans will give a better balanced feed as the Sudan Grass is low in protein, while that of soy bean is high. If the seed is inoculated with Stimugerm a better stand will be assured, growth will be promoted and soil conditions improved enormously.

MAMMOTH YELLOW-We handle this variety only, as it is the most extensively grown for beans and forage, both of which it yields in great abundance. It grows more than 3 feet high, is erect in growth and can be cut with a mower. Ask for prices.

\section{Vetch-Hairy, or Winter}

Vetch is rapidly coming into favor as a winter cover crop, also desirable to plow under for green manure, or can be pastured or cut for hay. All kinds of stock relish it and thrive on it. It is claimed that a ton of Vetch Hay contains 50 lbs. of nitrogen and the roots and stubble $121 / 2$ lbs. more. Yields several tons of hay to the acre on good land. If sown in the spring, it will produce a crop which can be cut for hay in midsummer and second growth pastured afterwards.

Alone sow 50 to $60 \mathrm{lbs}$. to the acre. Can be used with Oats, sowing 25 to $30 \mathrm{lbs}$. of Vetch with 1 bu. Oats.

In the fall when most generally sown, it is best to use 25 to $30 \mathrm{lbs}$. of Vetch with $1 \mathrm{bu}$. Rye. Cover seed 1 to $11 / 2$ inches deep. September and October are the best months but ordinarily November is not too late. Vetch does well on any well-drained land, is never known to winter kill, and is wonderfully drought resisting. We cannot too strongly recommend Vetch, especially for fall sowing. It not only protects the land from winter leaching, but furnishes a fine pasture in the early spring and if not grazed too closely can be cut for hay, and when turned under it improves the land immensely. When Vetch is sown in a field for the first time the seed should be innoculated. This can be done by using Stimugerm. Ask for prices.

\section{Pop Corn}

A profitable crop especially for boys and girls to raise as it can be sold to grocers and popcorn venders. It is also one of the best crops for forage and early feed as it produces an abundant crop of the highest feeding value. For fodder plant $1 / 2$ bu. to the acre in 3 to 4 foot rows. By July it is full grown and has an abundance of ears in the milk. This crop can be cut and fed to stock. It can also be planted up to July 4 th. When planted for corn it should be planted much thinner, one stalk to the hill, every three or four inches in the row. Pop Corn and Cow Peas Mixed-make an ideal combination and the cheapest of hay. Use one-fourth bushel of Pop Corn three-fourth bushels of Cow Peas per acre. It cures easily and makes a balanced ration.

WHITE RICE-Best and most popular variety for popping. Pops pure white and the qualitv is the highest. Very prolific, producing 1 to 6 ears to the stalk. Postnaid, pkt, 10c; 1/ lb. $15 \mathrm{c}$ lb. $25 \mathrm{c} ; 2$ lbs. $45 \mathrm{c} ; 5$ lbs. $90 \mathrm{c} ; 10$ lbs. $\$ 1.50$. 


\section{SELECTED FIELD SEED CORN}

CULTURE-Grown for ears, 14 lbs. of seed per acre are planted in hills. For ensilage, 16 to 18 lbs. per acre planted in rows. For green feed crop use 50 to $100 \mathrm{lbs}$. per acre, broadcasted or planted thickly with a grain drill. Plant from April to July. To secure an abundant and paying crop use plenty of well rotted manurf and $250 \mathrm{lbs}$. 16\% Acid Phosphate per acre.

\section{Early Yellow Dent}

A high yielding, early maturing variety producing big yields on good land. A medium rough ear 10 to 12 inches long and bright yellow color. Grains are deep and closely set on small cob 14 to 16 rowed. Stalks are sturdy and have a distinct two-eared characteristic, making this variety an extra heavy yielder. Especially popular, due to its early maturity and drought resisting qualities. Planted during early spring for a quick green feed crop and a main crop for grain. Matures in 90 to 100 days. Postpaid, lb. 20c: 2 lbs. 30 c; $1 / 2$ pk. 80 c ; pk. $\$ 1.35 ; 1 / 2$ bu. $\$ 2.45$; bu. (56 lbs.) $\$ 4.50$.

\section{White Snowflake}

A splendid early maturing variety, siving a heavy yield of grain or fodder for ensilage; also makes a good roasting ear and fine meal. Suitable alike for earliest planting or the main crop or as a catch crop as it can be planted as late as July. Large, moderately smooth ears, 8 to 11 inches long, with medium depth pure white grains and usually 2 ears to the stalk. Broad leaves borne on heavy stalks growing 7 to 8 feet tall allowing close cultivation. Matures in 90 to 110 days. Postpaid, lb. 20c: 2 lbs. $30 \mathrm{c}$; $1 / 2$ pk. $80 \mathrm{c} ; \mathrm{pk}$. $\$ 1.35$; $1 / 2$ bu. $\$ 2.45$; bu. (56 lbs) $\$ 4.50$.

\section{Boone County White}

Standard medium late maturing white variety, extensively used for grain and ensilage. The ears are from 9 to 12 inches long, $7 \frac{1}{2}$ to $81 / 2$ inches in circumference, containing 18 to 24 rows, 1 to 2 ears to the stalk. The cob is medium size, and pure white in color. The ears are quite uniform in size, shape and appearance. Kernels are pearl white, quite deep. This variety grows a large stalk from 10 to 12 feet high, with an abundance of foliage. Will grow on poor thin land and produces a good crop even in dry seasons. Matures in 110 to 120 days. Postpaid, lb. $20 \mathrm{c} ; 2$ lbs. $30 \mathrm{c} ; 1 / 2$ pk. $80 \mathrm{c} ;$ pk. $\$ 1.35$; $1 / 2$ bu. $\$ 2.45$; bu. (56 lbs) $\$ 4.50$.

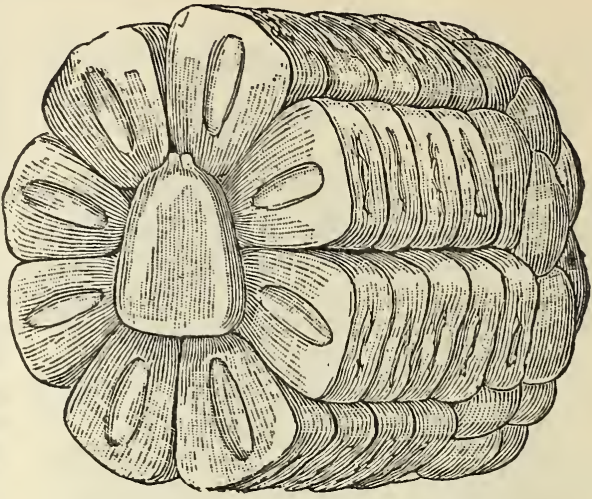

\section{Hickory King}

A late maturing prolific variety, with very broad and firm flat grains. The ears average about 8 inches long. The cob is exceedingly small, not much larger than a man's finger, and has 10 or 12 rows. Fine for meal and makes good roasting ears. It is especially recommended for high land and can be depended upon to produce a crop on poor, thin land; on good land it bears two or three ears to the stalk. Our seed in very carefully grown; selected in the field, hand shelled, nubbed at both ends. Matures in 115 to 125 days. Postpaid, lb. 200: 2 lbs. 30 c; $1 / 2$ pk. 80 c ; pk. $\$ 1.35$; $1 / 2$ bu. $\$ 2.45$; bu. (56 lbs.) $\$ 4.50$.

\section{Hastings Prolific}

This late maturing variety is particularly adapted to heavy bottom lands and for seasons when there is an excess of rainfall. It is a rather hard flinty corn, pearly white on medium sized ears up to 12 inches long. Stalks are 10 to 12 feet tall, producing 2 to 5 ears. Good for ensilage and fine for making hominy and meal. The ears are well filled at both ends; the cob is small; the shuck is heavy and covers the ear tightly; protecting it from birds and insects, and preventing loss in wet seasons. Matures in 115 to 125 days. Postpaid, lb. $20 \mathrm{c}$; 2 lbs. $30 \mathrm{c}$; $1 / 2$ pk. $80 \mathrm{c}$; pk. $\$ 1.35$; $1 / 2$ bu. $\$ 2.45$; bu. (56 lbs.) $\$ 4.50$.

\section{Eureka Ensilage.}

This is a medium late maturing corn, being fine for ensilage, as it is tall and leafy,

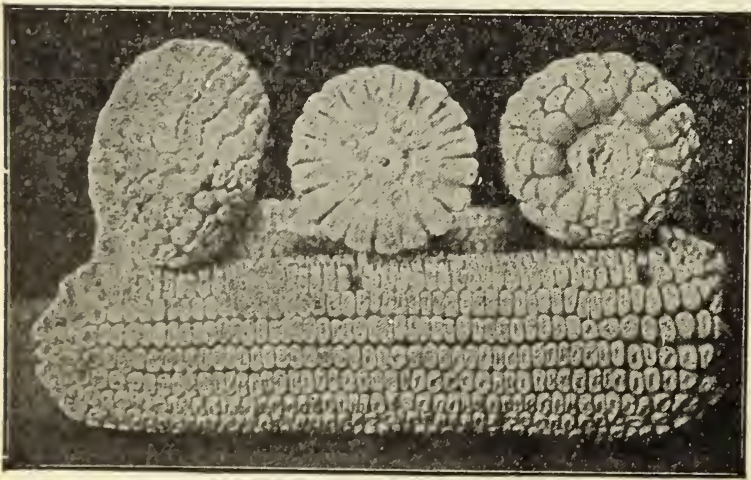
growing 12 to 15 feet high and producing an enormous growth of fodder. This corn also ranks high as a field corn, being a heavy yielder, producing one to two ears to the stalk, the ears frequently over 12 inches. Eureka corn should be grown on bottom lands and low grounds, as it is a prolific corn and such corn should only be grown on good land. Matures in 110 to 120 days.

Postpaid, lb. 20c; 2 lbs. 30c; $1 / 2$ pk. $80 \mathrm{c} ;$ pk. $\$ 1.35$; $1 / 2$ bu. $\$ 2.45$; bu. (56 lbs.) $\$ 4.50$.

BEFORE BUYING YOUR SEED CORN WRITE FOR CURRENT PRICES NOT PREPAID 


\section{COMMERCIAL FERTILIZERS}

Prices are for Cash, F.O.B. Asheville, subject to market change. When you are ready to buy, ask for firm price. No articles on this page, except Stim-U-Plant and Grogreen, can be mailed.

The Yield And Quality Of Vegetables Depend Upon Continuous And Rapid Growth

\section{Acid Phosphate}

Analysis 16 Per Cent Available Phosphoric Acid. Recommended for all grain, cow peas and soy beans on rich bottom lands. Beneficial results follow the addition of acid phosphate to stable, barnyard, sheep and poultry manure. Invaluable to use after plowing under a cover crop. Acid Phosphate contains from 40 to 50 per cent calcium sulphate or land plaster, which is of value as an absorbent of liquid manure; also as an insecticide against cucumber, melon and squash pests. Apply 300 to $500 \mathrm{lbs}$. to an acre. Price Bag (200 lbs.) $\$ 2.5 \mathrm{C}$; ton $\$ 22.50$.

\section{Grain And Grass Fertilizer}

Analysis: 2\% Ammonia ; $8 \%$ Available Phosphoric Acid; $2 \%$ Potash. This is a quick acting and excellent fertilizer, especially prepared for grain and grass crops. The great popularity of this fertilizer is due to the increased production of crops and the permanent improvement of the soil that has resulted by its use. Also good for vegetables. Apply 500 to 700 lbs. per acre.

Price-Bag, 200 lbs. $\$ 3.15$; ton $\$ 29.00$.

\section{Vegetable and Potato Fertilizer}

Analysis: $4 \%$ Ammonia; $8 \%$ Available Phos. phoric Acid; $4 \%$ Potash. Apply 800 to $1000 \mathrm{lbs}$. to the acre. This complete fertilizer is especially prepared for beans, peas, cabbage, tomatoes, potatoes, tobacco, and all vegetables. The proportions are well balanced for soil conditions in this section. The ingredients dissolve quickly and supply available plant food immediately, producing wonderful results by the stimulation of the vegetable plants into a luxuriant growth. 100 lbs. $\$ 2.25$; Bag (200 lbs.) $\$ 4.00$; ton $\$ 37.50$.

TOBACCO FERTILIZER (8-4-4)-Specially prepared for tobacco crops. Bag (200 lbs.) $\$ 4.10$; ton $\$ 38.50$

\section{Pure Raw Bone Meal}

Approximate Analysis: 20\% Available Phosphoric Acid: $4 \frac{1}{2} \%$ Ammonia equivalent to $3.70 \%$ Nitrogen. Bone Meal is an excellent slow acting fertilizer for all kinds of fruit trees, rose bushes, grape vines, bulbs, geraniums, ferns, palms, and other potted plants; and for grass erops. It dissolves gradually, supplying food steadily during the growing season. For lawns, etc., use $200 \mathrm{lbs}$, to every 3000 square feet; one ton per acre and work in well. As a top dressing use one-half the above amount.

Not prepaid 5 lbs. $35 \mathrm{c} ; 10 \mathrm{lbs} 60 \mathrm{c} ; 25 \mathrm{lbs}$. $\$ 1.25$

so lbs. $\$ 2.00$; 100 lbs. $\$ 3.50$; Bag (200 lbs.) \$6.50;

$1 / 2$ ton $\$ 31.00$; ton $\$ 60.00$.

\section{Pulverized Sheep Manure}

This is a pure, natural manure, and its effect is immediate. It is excellent for mixing with the soil for greenhouse plants-one part of manure and ten parts soil. Strewn over and dus into the flower or vegetable garden or placed directly in drills or hills it promotes a rapid, steady growth until maturity. Being free from noxious weeds, it is vastly superior to stable manure for enriching lawns. It makes the richest, safest and quickest Liquid Manure. For use in liquid form, $1 \mathrm{lb}$. to 5 gallons of water will make a liquid which can be used safely daily if aecessary. For lawns and gardens apply 100 lbs. to every 1000 sq. ft., 1 to 2 tons per sere and work in thoroughly. As a top dressing use one-half the abore amount.

Not prepaid 5 lbs. 30c; 10 lbs. 50c; 25 lbs. $\$ 1.00$ 50 lbs. $\$ 1.75$; Bag (100 lbs.) $\$ 3.00$; 500 lbs. $\$ 13.75$ 1,000 lbs. $\$ 25.00$; ton $\$ 48.00$.

\section{Nitrate of Soda}

Used as a top dressing at the rate of one ounce to the square yard in the early spring and again when the plants are half grown. Can be mixed with its equal weight of acid phosphate and worked well into the soil. For home gardens it is safer to apply as a solution, using I ounce to 2 gals. of water. Keep off foliage.

Not prepaid lb. 10c; 5 lbs. $40 \mathrm{c} ; 10 \mathrm{lbs}$. $75 \mathrm{c}$; 25 lbs. $\$ 1.25 ; 50$ lbs. $\$ 2.25 ; 100$ lbs. $\$ 4.00$; 200 lbs. $\$ 7.50$.

\section{ARCADIAN SULPHATE OF AMMONIA}

A dependable and lasting form of ammonia $251 / 4 \%$; equivalent to $203 / 4 \%$ of Nitrogen.

For lawns apply two pounds Sulphate of Amonia for each 1000 square feet. Sprinkle with water after each application.

Not prepaid, 5 lbs. $45 \mathrm{c} ; 10$ lbs. $75 \mathrm{c} ; 25 \mathrm{lbs}$. $\$ 1.50$; 50 lbs. $\$ 2.50 ; 100$ lbs. $\$ 4.50 ; 200$ lbs. $\$ 8.00$.

\section{Tobacco Dust}

The high percentage of potash and ammonia in this excellent fertilizer renders it invaluable for mulching. Can be used in connection with other fertilizers on lawns and for cucumbers, squash and melons, as it aids in driving off ants and other insects. Alone use 100 lbs. to every 1000 square $\mathrm{ft}$. or one part Tobacco Dust with ten parts soil or equal weight of acid phosphate and work in.

Not prepaid 5 lbs. $30 \mathrm{c} ; 10$ lbs. $50 \mathrm{c} ; 25$ lbs. $\$ 1.00$; 50 lbs. $\$ 1.75$; Bag (100 lbs). $\$ 3.00$.

\section{Hydrated Lime}

Sweetens soil where too much acidity exists and helps flowers, vegetables and grass to grow. Use 1 pound to 20 square feet or 50 pounds to 1,000 square feet of new lawn, and half that quantity for top dressing old ones.

Not prepaid, $10 \mathrm{lbs} .25 \mathrm{c}$; $50 \mathrm{lbs} .75 \mathrm{c}$.

\section{GRANULATED PEAT MOSS}

It is invaluable as a soil conditioner as it adds humus, improves the texture, conserves moisture and aerates the soil. It is used extensively for mixing in soil for pot plants, window boxes and it is excellent medium in which to grow bulbs. The rich mellow texture that it imparts to the soil puts it in ideal condition for the making of a lawn, a flower or a vegetable garden. It is also used for mulching perennial plants and rose beds as well as evergreens. Peat Moss may also be used for packing and storing bulbs, such as Cannas, Dahlias, etc.

Not postpaid, 5 lbs. $30 \mathrm{c} ; 10 \mathrm{lbs} .50 \mathrm{c} ; 25 \mathrm{lbs} \$ 1.15$; 50 lbs. $\$ 2.00$; 100 lbs. $\$ 3.50$; bale (about 170 lbs $\$ 5.00$.

\section{Stim-U-Plant}

A highly concentrated, odorless fertilizer for the vegetable and flower garden, shrubs and house plants. The analysis is guaranteed 11 per cent nitrogen, 12 per cent phosphoric acid, 15 per cent potash, an ample amount of each plant food to insure a quick and strong growth of all plants, earlier maturity of garden vegetables, and a generous supply of blooms from flowering plants. Postpaid, 30-tablet pkg. 25 cts.; 100-tablet pkg. 75 cts.; 1000-tablet pkg. $\$ 3.50$.

\section{Grogreen}

A wonderful fern food and indoor plant stimulator. Postpaid ; 4 oz. pkt. $12 \mathrm{c}$; 5 pks. 50c: Not prepaid, pkt. $10 \mathrm{c}$. 


\title{
INSECTICIDES AND FUNGICIDES
}

\section{No Article On This Page Can Be Mailed Except Those Quoted "Postpaid"}

\author{
Please write for prices in larger auantities than quoted below, stating quantity wanted.
}

ANTROL-A complete control system of combating ants, consisting of special glass containers and Antrol syrup. Cottage set containing nine receptacles and $6 \mathrm{oz}$. bottle of syrup, $\$ 1.50$; extra pt, bottles of syrup, $95 \mathrm{c}$ each; extra receptacles, $15 \mathrm{c}$ each.

ARSENATE OF LEAD-An arsenical polson for use against "chewing" insects.

Use 1 to $11 / 2$ lbs. Arsenate of Lead to $50 \mathrm{gal}$. lons of water. Arsenate of Lead is also used in combination with Bordeaux Mixture and Dry Lime Sulphur as described under those articles. Price, lb. $35 \mathrm{c} ; 3$ lbs. $75 \mathrm{c}$.

"BLACK LEAF 40"-Destroys "sucking" insects such as Aphis (Plant Lice), Thrips, Leaf Hoppers. Contains $40 \%$ of nicotine. One ounce bottle makes about 6 gallons: 1/ $\mathrm{lb}$. bottle makes from 40 to 150 gallons. 1 teaspoonful to 1 gallon of water. It has been discovered to be a very efficient control for Poultry Lice.. Write for folder. Price, 1 oz. $35 \mathrm{c}$; $1 / 2$ lb. bottle $\$ 1.25 ; 2$ lb. tin $\$ 3.25 ; 10 \mathrm{lb}$. tin $\$ 11.85$.

BORDEAUX MIXTURE-A standard fungicide and may be used in combination with inaecticides. Its use is indispensable in the control of black rot of grapes and the blight of potatoes. It is also used for apple-scab, bitter-rot, cedar rust, leaf spot and downy mildew. Use 6 to 7 pounds to 50 gallons of water. To make a combined Fungicide and Insecticide, add 3 to $4 \frac{1}{2}$ lbs. Arsenate of Lead to 150 gallons of the diluted mixture. Not prepaid, lb. 25c; 4 lbs. 80c.

CALCIUM ARSENATE-Used as dust for Bean Beetle and Potato Bugs. Mix 1 lb. Calcium Arsenate with 9 lbs. Hydrated Lime. Apply 15 to 20 lbs. of mixture per acre. Lb. 25c; 3 lbs. 50c.

COPPER SULPHATE (Blue Stone or Vitriol)Used in making Bordeaux Mixture in combination with hydrated lime. For smut in grain, $1 \mathrm{lb}$. Copper Sulphate to 20 gals, water, and use as quickly as possible. As a poultry laxative, use $1 \mathrm{oz}$. to 10 gals. water.

Postpaid, lb. 30 c; 5 lbs. 95 c; 10 lbs. \$1.65.

Not prepaid, 1b. 20c; 5 lbs. $75 \mathrm{c} ; 10$ lbs. $\$ 1.40$.

COW EASE-A light spray for using on cows and horses to prevent flies, gnats and mosquitoes. Postpaid, qt. 65c; $1 / 2$ gal. \$1.10; gal. \$1.75.

Not prepaid, qt. $50 \mathrm{c}$; $1 / 2$ gal. $85 \mathrm{c}$; gal. $\$ 1.50$.

DRY LIME SULPHUR-For control of all scales, San Jose, Oyster Shell, etc., when trees are in a dormant state, use 12 to 15 lbs, to 50 gallons of water.

For control of Apple and Pear Scab, use 3 to 4 lbs. Dry Lime Sulphur and $1 \mathrm{lb}$. Arsenate of Lead to 50 gals. of water.

For summer spray to make a combined Insectieide and Fungicide, use $2 \frac{1}{2}$ to 3 lbs. Dry Lime Sulphur and 1 to $1 \frac{1}{2}$ lbs. of Arsenate of Lead to 50 gallons of water.

Postpaid lb. 40c: 5 lbs, $\$ 1.40 ; 10$ lbs, $\$ 2.25$ Not prepaid, lb. 30c; 5 lbs. $\$ 1.25 ; 10$ lbs. $\$ 2.00$.

DOWCO-A powdered combination of Bordeanx and Arsenate of Lead, thus forming a remedy for both fungus diseases and "chewing" insects on flowers, vegetables, potatoes, tomatoes, melons, berries, grapes, etc Fine for roses, etc., except against Aphis, Thrips and Leaf Hoppers, for which add "Black Leaf 40" to Dowco Also an effective summer spray for all fruit trees except pearh and Japanes? plum.

Use $1 \mathrm{lb}$. with 6 to 8 gals. water or 6 to 8 evel teaspoonfuls to 1 gallon of water.

Price lb. $35 \mathrm{c}: 4$ lbs. $\$ 1.20$.
90-10 DUST-A poison combination eonsisting of $90 \%$ Sulphur and $10 \%$ Arsenate of Lead Splendid for dusting roses and all plant against mildew and "chewing" insects.

Price lb. $15 \mathrm{c} ; 5$ lbs. $65 \mathrm{c} ; 10$ lbs. $\$ 1.20$.

FLY DEATH-A spray for use around the house against flies and mosquitoes. Outfit consists of a tin sprayer and $6 \mathrm{oz}$. can of liquid.

Postpaid, $60 \mathrm{c}$; Not prepaid $50 \mathrm{c}$.

Refils (6 oz. cans) Postpaid $30 \mathrm{c}$; Not prepaid $25 \mathrm{c}$. Quart, postpaid $\$ 1.15$; Not prepaid, quart $\$ 1.00$.

FISH OIL SOAP (Formerly Called Whale Oil Soap)-Used for combating many insects infesting trees, vines and plants. For indoor plants, $1 \mathrm{lb}$. to 8 gals water. For outdoor plants, $1 \mathrm{lb}$ to 4 gals. water. Kerosene Emulsion can be made from fish oil soap by adding kerosene in the proper proportion.

Postpaid; $1 \mathrm{lb}$. Can 40c; 6 Cans $\$ 1.75$

Not prepaid; 1 lb. Can 30c; 6 Cans $\$ 1.50$.

HAMMOND'S GRAPE DUST-A practical and usually effectual remedy against most powdery mildews on flowers and fruits, especially on grapes and roses. Apply with bellows or powder sprayer. Postpaid lb. box $40 \mathrm{c}$; Not prepaid $30 \mathrm{c}$.

MAGNESIUM ARSENATE-Used for controlling the Bean Beetle pest and will not burn the tender bean foliage. 2 lbs, makes 100 gals. solution, sufficient to spray one acre. 2 to 3 level tablespoonfuls to 1 gallon of water. $2 \mathrm{lb}$. pkg. $65 \mathrm{c}$.

PARA DICHLOROBENZINE-Insecticide for Peach Tree Borer. In May or during September and October use $1 / 2$ to $11 / 2$ ounces to each tree, depending on size.

Postpaid, lb. 60c; 5 lbs. $\$ 2.20 ; 10$ lbs. $\$ 4.00$

Not prepaid, lb. $50 \mathrm{c} ; 5$ lbs. $\$ 2.00 ; 10 \mathrm{lbs} . \$ 3.75$.

RED CROSS RAT AND MOUSE EMBALMER -A most effective poison against rats and mice. It dries them up mummifies the dead bodies and leaves no odor, providing a sufficient amount is used to insure every rat getting enough Used by biggest flour mills grocers, railroads, etc. in United States. Price, $25 \mathrm{c} ; 50 \mathrm{c} ; \$ 1.00$.

SLUG SHOT-A fine powder, easily distributed by duster, bellows or in water by spraying. It is thoroughly reliable in killing worms, bugs, fungi, etc., on roses and vegatables. Also used to control Mevican Bean Beetle. Can be used on ripening fruits, berries and vegatables, as it is practically non poisonous to man.

Postnaid lb. 35c; 5 lbs. $75 \mathrm{c} ; 10$ lbs. $\$ 1.40$

Not prepaid, lb. $25 \mathrm{c} ; 5$ lbs. $60 \mathrm{c} ; 10$ lbs. \$1.15.

SNAROL-An effective bait for controlling Cutworms, Girsshopners, Snails, Slugs and Sow Bugs. Not injurious to plants or other vegetation. One pound, 50 cts.; three pounds, $\$ 1.00$.

SULPHO TOBACCO SOAP-A combination of Nicotine, Sulphur and Soap for spraying against Aphis, Mealy Bug, Red Spider and many other sucking insects; especially recommended for Roses. 8 oz. cake makes 4 gals. solution. Aleo an excellent soap for dogs and other animals.

Postpaid, $30 \mathrm{c}$; Not prepaid $25 \mathrm{c} ; 5$ cakes $\$ 1.00$.

VERMINGO-Insecticide and Disinfectant. It kills by contact, bed bugs, roaches, fleas, moths, lice, ants, etc. Use freely in house as disinfece tant. Postpaid, pint, 65c; at., \$1.05; gal., \$2.75. Not prepaid, pt., $50 \mathrm{c}$; qt., $85 \mathrm{c}$; gal. \$2.50.

WEED KILLER-Destroyes Poison Ivy, Weeds and Grass anywhere that vegetation is not wanted. To be diluted at the rate of 1 quart to 8 to 10 gallons water. Quart, 75c. 


\section{HUDSON BULL DOG BARREL SPRAYER}

The Hudson Bull Dog Sprayer develops a working pressure of $200 \mathrm{lbs}$. It is adapted for orchard work, vineyards, spraying shade trees and ornamental shrubs, for use with stock dips and disinfectants in stock yards, cattle pens, hog houses, chicken ranches, etc. or for whitewash and coldwater paints. Easily moved from place to place in a wagon or sled.

Pump is of compound, high pressure, horizontal type. Fitted with ball valves accessible without dismantling the pump: Seamless brass cylinder and piston with brass bushings: Large air chamber and $200 \mathrm{lb}$. pressure gauge. Tank is a 50 gallon welded steel barrel which will not warp or dry out. Fitted with swinging agitator. Fastened to skids with steel straps. Skids are of first grade lumber, securely bolted together. Well painted. Discharge Equipment consists of 6 feet of $3 / 8$-inch spray hose and a 4-foot extension rod, -total 10 feet, Ideal spray nozzle and leakless brass shut-off valve. Fitted for two leads of hose, one outlet' capped.

No. 47, Complete as shown, $\$ 60.00$.

\section{Hudson Bamboo Spray Pole}

Hudson Bamboo Spray Poles are brass lined. This lining is in one piece, locked to the poles at both ends. Will not turn inside the bamboo," because of the special end castings. Fitted with adjustable brass drip shield and stop cock. Recommended for all work where an extension rod longer than 4 feet is required.

No. 44. $10 \mathrm{ft}$. Price with stop cock $\$ 3.90$.
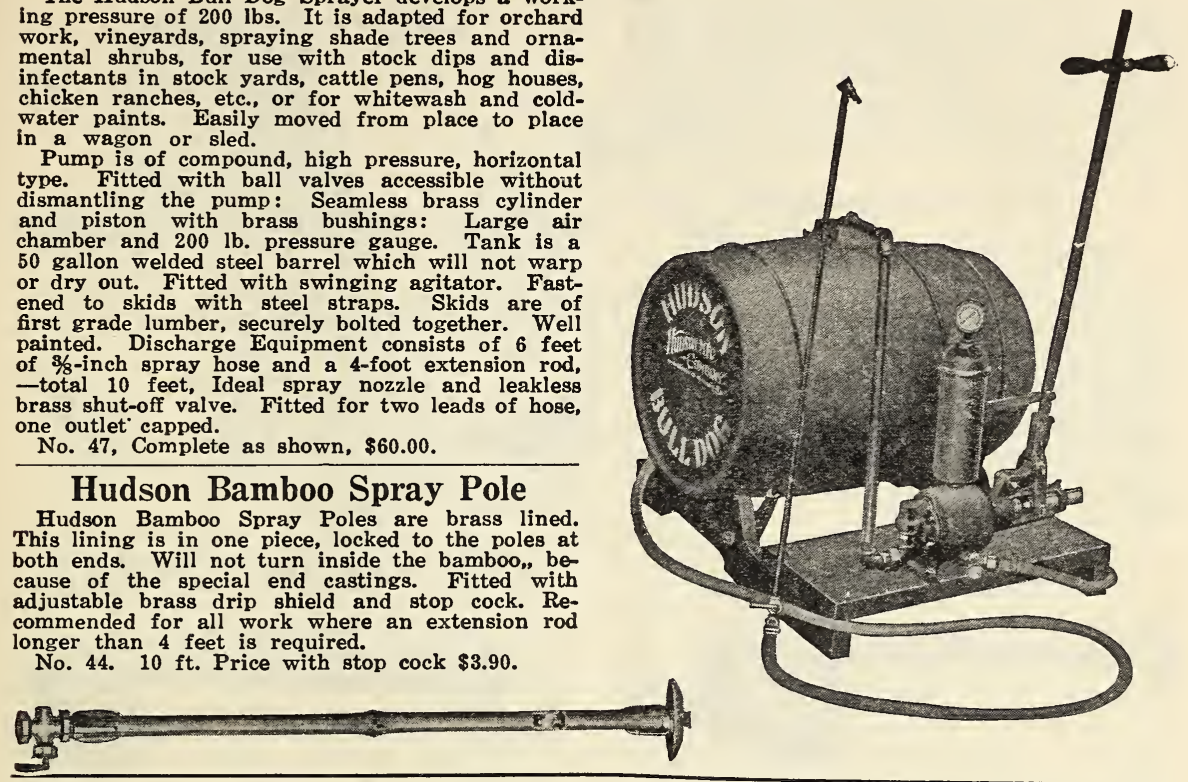

\section{Perfection Compressed Air Sprayer}

The Perfection Sprayer combines all the essential features of a successful compressed air sprayer. The tank is riveted and soldered exactly like a steam boiler. It will withstand any pressure with perfect safety to the operator. The pump is all brass and properly proportioned. The Nozzle is the most satisfactory shut-off nozzle made; it will close tight under any pressure and there is consequently no leakage or damage to clothing, floors, etc. It will handle all solutions.

The Perfection is a practical Sprayer for use around the orchard, barn, outhouses; on truck farms ; in onion, melon and small potato fields. It will handle whitewash and cold-water paints in a most satisfactory manner. The uses are many and varied.

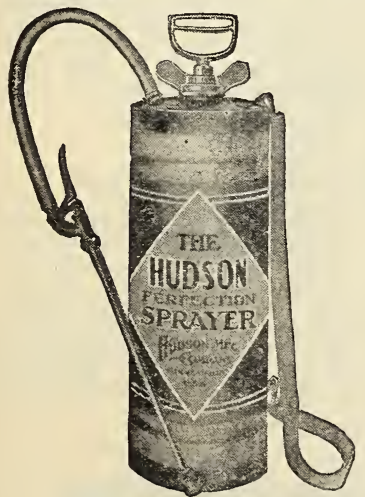

Tank - 71/2 inches diameter, 20 inches high ; capacity approximately four gallons. Made in either galvanized or brass. T h brass tank is recommen d e d when e ver a strongly corra sive solution is used, because it resists the action of the solution better than the galvanized. Copper - bearing g a l v a n ized sheet is used exclusively in the galvanized tank, as that is rust resisting and gives the sprayer a longer life.

Brass Tank $\$ 9.50$

Galvanized Tank

If to be sent parcel post please add $25 \mathrm{c}$ to cover postage and packing.

\section{Hudson Junior Sprayer}

The Hudson Junior Sprayer is a high pressure compressed air sprayer. It is particularly adapted for the backyard garden or small truck farm, for use around the chicken house, in the dairy barn, hog pen, or for disinfectants in hotels, restaurants, theatres \& other public buildings. It is substan. tially made and thoroughly tested under actual working conditions at factory.

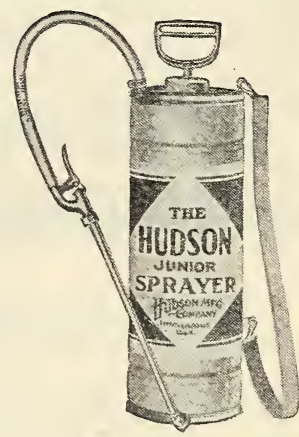

Galvanized Tank-61/2 in. diameter, 17 in. long: capacity approximately $21 / 2$ gallons.

Pump-18/4 inches diameter, 15 inches long, seamless brass tubing. Equipped with special cupped Hudson leather and heavy rod. Valve is brass, automatic in operation, operates perfectly under all pressures. Seals into tank by a half turn of the handle. Releases by reversing the process.

Postpaid, $\$ 5.25$; Not prepaid $\$ 5.00$

\section{Aphis Fitting No. 146}

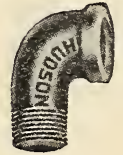

For use with Perfection and Hudson Junior Sprayers. The attachment permits spraying under surfaces of low-lying plants and shrubs. Postpaid, 35c ; Not prepaid, 30c. 


\section{ARMSTRONG STANDARD SPRAY PUMP}

The Armstrong Standard Spray Pump is a very simple and unusually powerful direct acting pump that meets every spraying requirement. It may be used with a bucket, barrel or knapsack-for spraying fruit and garden crops, disinfecting, whitewashing, spraying cattle dip and fly spray, washing automobiles, fire fighting and countless other purposes.

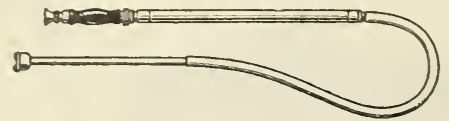

Pump only for Spraying from Bucket.

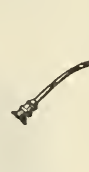

Made entirely of brass, there is nothing about it to dry out or rust, no leather washers to rot.

By different combinations of the nozzles, sprays are produced, varying according to the need, from a fine mist to a straight stream. The nozzle for force of this spray resists the wind and penetrates the thickest foliage. You can spray the tallest fruit tree from the ground.

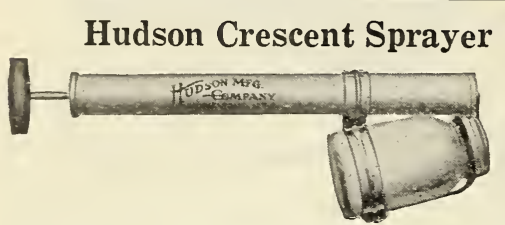

The Hudson Crescent possesses sanitary features which appeal to many people. Any quart size Mason jar can be used. A change from one solution to another can be made by simply changing jars. It is a strong, well made sprayer equipped with double discharge tubes which produce a wide fan-shaped spray.

Pump is heavy tin. Tank is quart glass Mason jar, furnished with gasket to prevent leakage.

Postpaid, 90c; Not prepaid, $75 \mathrm{c}$.

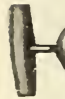

\section{Rainbow Liquid Sprayer}

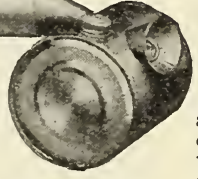

The Rainbow Sprayer is very serviceable for light work, and is economical in the use of material. Used for liquid sprays on flowers and vegetables, and for handling Cow Ease, Vermingo, Noxicide and other disenfectants around the home, chicken houses, etc. Tank: one full quart capacity; made of heavy tin, lockseamed and leakproof. Postpaid $60 \mathrm{c}$. Not prepaid $50 \mathrm{c}$.

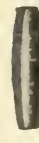

\section{HUDSON POWDER SPRAYER}

\section{Hudson Major Duster}

The MAJOR handles Arsenate of Lead, Calcium Arsenate, Magnesium Arsenate and similar poisons very efficiently. Fitted with powder strainer to prevent clogging. The extension pipe has two angle nozzles for spreading the dust under the leaves of low-growing plants.

Postpaid \$1.40. Not prepaid \$1.25.
Armstrong Standard Pump With Knapsack And Potato Extension Attachment.

\begin{tabular}{|c|c|c|}
\hline Un & $\begin{array}{l}\text { Postpaid } \\
5.10\end{array}$ & Not Postpaid \\
\hline sack & 4.15 & . $\quad 4.00$ \\
\hline Exter & 1.10 & 1.00 \\
\hline erinary Nozzle ..................... & .55 & .50 \\
\hline plete Outfit ..................... & 10.90 & 10.50 \\
\hline Per Ft................ & .20 & 18 \\
\hline
\end{tabular}

\section{Lowell Continuous Sprayer}

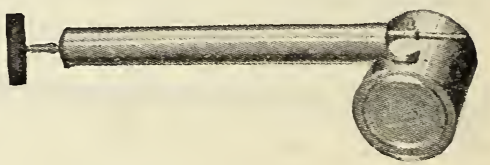

The Lowell Continuous Sprayer is a tin sprayer, which delivers a continuous mist like spray. Will handle any solution which does not contain sediment. $11 / 2 \times 14$ inch air chamber. 3-16 inch brass ball check valve. Capacity one full quart. Postpaid $\$ 1.00$. Not Prepaid 90c.

\section{Hudson Bellows Duster}

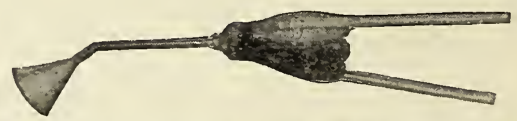

The Hudson Bellows Duster is used with Arsenate of Lead, Calcium Arsenate and other powdered insecticides in truck gardens, potato patches, tobacco fields, cotton fields, etc. The funnel unscrews from the bellows so that the powder is put directly inside the duster. It is kept constantly agitated by the action of the bellows, providing a uniform discharge.

Postpaid, \$2.00. Not prepaid, \$1.75.

\section{Hudson Powder Sprayer}

The Hudson Powder Sprayer will handle all dry powdered insecticides such as Slug Shot, Calcium Arsenate, etc., in a very satisfactory and economical manner. It is particularly adapted to combat the Bean Beetle pest as the powder can be blown up under the powder can be blown up under the ing about cne quart; lockseamed and leakproof. Postpaid, 60c. Not prepaid, 50c.

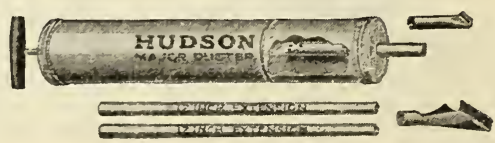




\section{ORCHARD, LAWN AND GARDEN TOOLS}

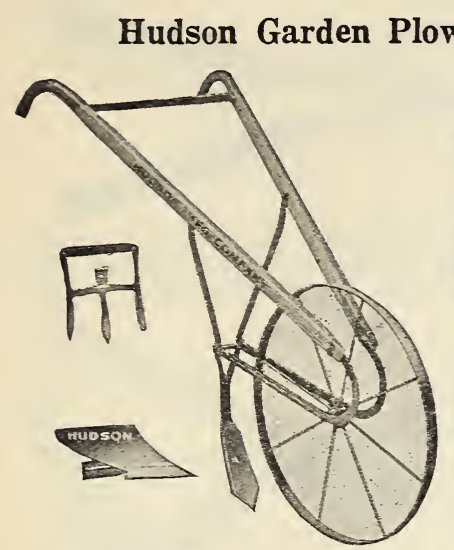

The Hudson Garden Plow is a favorite with truck farmers and home gardeners. It is a great time saver and pays for itself in a few days.

The Plow and double-pointed shovel, are made of regular plow steel. Surfaces are polished and lecauered and cutting edges sharpened. Combimation Rake and Scuffer hoe is malleable iron with carbon steel blade. Frame is steel with adjustments for varying the pitch of the tools. Handles are seasoned hardwood, reinforced at tips with steel straps to prevent splitting, and adjustable in height. Wheel is 24 inches high with $1 \frac{1}{4}$ inch tire, insuring easy running.

Price, \$4.50.
Hudson Seeder and Single or Dou= ble Wheel Cultivator. No. 201

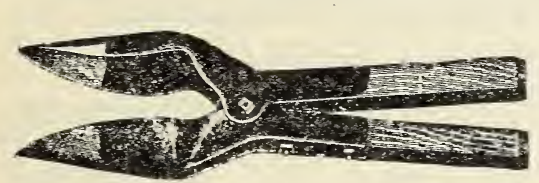

POST HOLE DIGGER-Hardwood handles, round taps, square shoulders, fitted into one solid socket and bolted; one piece solid steel blades of first quality; blades 9 inches long. Digs 6-inch bole; length over all, 57 inches; point of blades polisbed. Not Prepaid, $\$ 2.00$.

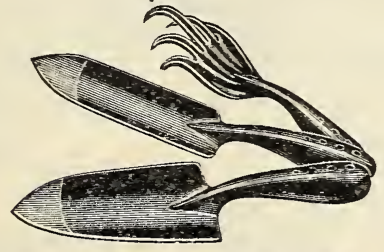

THREE PIECE GARDEN SET.

Set of Three Tools: One regular Trowel, one Transplanting Trowel, and one Weeder. All made of heavy pressed steel, handsomely finished. Price, per set, Prepaid, $85 \mathrm{c}$.

Not Prepaid, 75c.

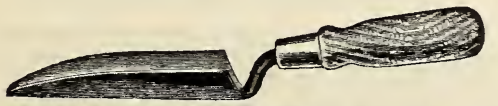

GARDEN TROWEL No. T10-Six-inch heavy crucible steel forged one piece, half polished and green enameled blade. Wrought ferrule. Hardwood handle. Postpaid, \$1.00: Not Prepaid, 90c.
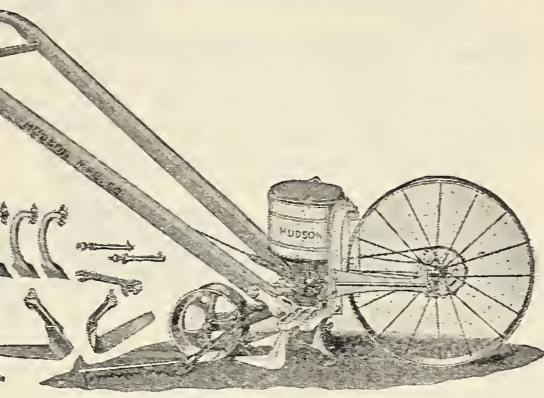

This machine is a combination outfit which, may be used as a hill or drill seeder, double or single wheel cultivator, plow or hoe, as conditions require. It is readily converted from one. use to another.

As a seeder, this machine opens the furrow, drops the seed, closes the furrow, packs the earth, and marks the next row-all in one operation. The seed regulator is made entirely of brass, with openings die cut to insure absolute uniformity. This gives perfect control of the seed flow and insures a uniform drop. Sows all seeds from beans down to the finest garden variety, in continuous. drills, or hills $4,6,8,10,12$ or 24 inches apart. Adjustments in furrow-opening shoe and furrow. coverer permit planting at any depth up to 2 inches. Complete as illustrated. (No. 201), \$21.50.

Single Wheel Seeder only (No. 205) \$18.00.

GARDEN TROWEL NO. T25-6 inch one-piece heavy rolled steel blade for transplanting. Postpaid 35c. Not prepaid 25c.

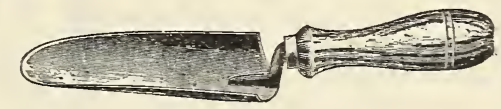

GARDEN TROWEL No. T20-6-inch rolled, steel, riveted blade, half polished and green en: ameled. Malleable tang.

Postpaid, 45c; Not Prepaid, 35c.

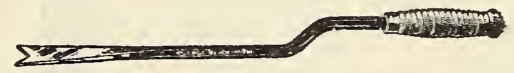

DANDELION DIGGER NO. 219-Made of octogon tool steel tempered 15 in. long. Can also. be used for an asparagus knife.

Postpaid, 60c; Not Prepaid, 50c.

\section{WATERING POTS}

Galvanized

Not Prepaid

4 qt.

6 qt.

.... $\$ .75$

6 at 8.95

8 qt. $\ldots-\ldots-\ldots 1.00$

10 qt. …_...

12 qt. …........\$ $\$ 1.30$

16 qt. …....... $\$ 1.50$

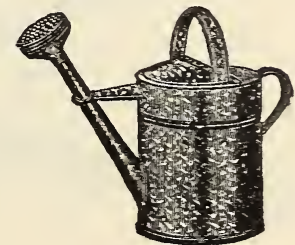




\section{ORCHARD, LAWN AND GARDEN TOOLS-Cont.}

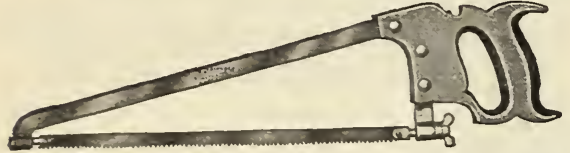

DISSTON PRUNING SAW No. 19-Crucible blued steel blade; polished flat steel frame, slightly tapered; riveted socket; swivel stretcher; adjustable blades; beechwood handle.

Postpaid \$2.10. Not prepaid, $\$ 2.00$.

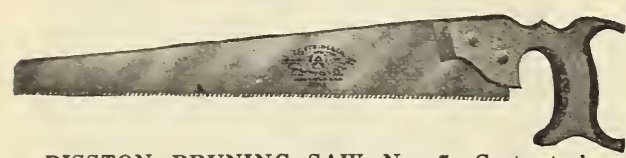

DISSTON PRUNING SAW No. 7-Cast steel blade, applewood handle, polished edges; 2 brass screws, length 18 inches.

Postpaid, $\$ 1.60$. Not Prepaid, $\$ 1.50$.

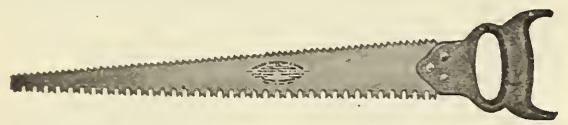

DISSTON PRUNING SAW No. 4-Duplex, double edge, cast steel blade, polished. Quick acting teeth on one side and plain teeth on reverse edge; beechwood handle, polished; 3 brass screws : 16 inches. Postpaid, \$1.85. Not Prepaid, \$1.75.

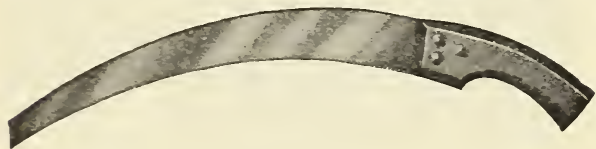

DISSTOY PRUNING SAW No. 50-Crescent shape; crucible steel blade, polished, carved beechwood handle, brass screws; 14 inches.

Postpaid, \$1.35. Not Prepaid \$1.25.

\section{DISSTON POLE PRUNERS-A} practical tool for orchardists, foresters, farmers and other users of pruning tools. The stout solid steel hook on the end of the pole is hooked to branch to be cut; a pull on the lever and the operation is completed. Immediately the lever is brought back into position for another cut by a coil spring attached to pole and lever.

$6 \mathrm{ft} ., \$ 3.00 ; 8 \mathrm{ft} ., \$ 3.50 ; 10 \mathrm{ft}$., $\$ 4.00 ; 12$ ft., $\$ 5.00$. Cannot be mailed.

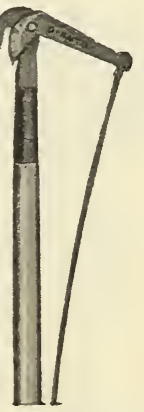

DISSTON'S LOPPING SHEAR No. 1-Polished

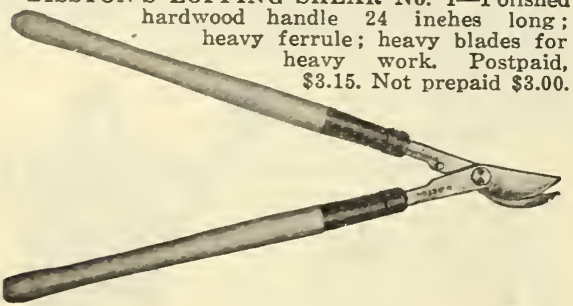

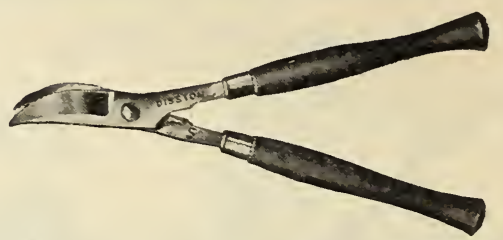

DISSTON'S UTILITY LOPPING SHEAR NO. 5 9 inch black handles; full polish $31 / 4$ inch blades. Postpaid, $\$ 2.15$. Not prepaid, $\$ 2.00$.

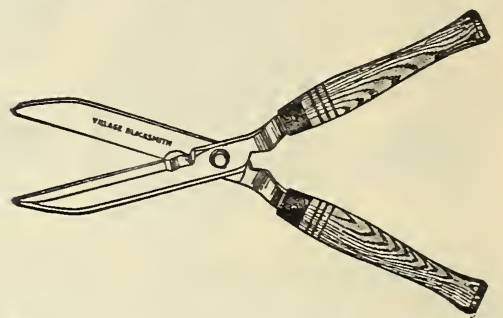

HEDGE SHEAR No. 900-Forged crucible steel notched, hammer finish; hardwood handles; blade 9 inches. Postpaid, \$2.75. Not Prepaid, \$2.50.

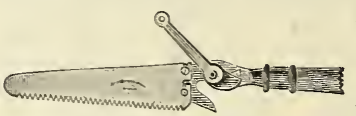

DISSTON'S LIT-

T L E G I A N T AND SAW - A cal and very useful tool for the small practiand private estate. Furnished only as illustrated without pole or rope.

Postpaid, \$3.60. Not prepaid, \$3.35.

PRUNING SHEAR No. 312-California pattern. Length

9 in. High grade tempered steel blade.

Double flat

brass spring

Adjustable

ratchet nut. Postpaid, \$1.45. Not prepaid, \$1.35.

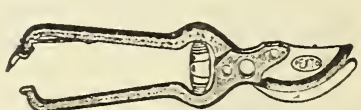

$P R$ U N I N G SHEAR No. 311 -California pattern. Length 9 in. Tempered tool steel blade. Vo-

lute spring. Postpaid, \$1.05. Not prepaid, 95c.

L A D I E S'

ROSE SHEAR

-A beautiful

finished, full

polished and

nickel plated

shear. Length 6 inches. Tempered steel blade.

Postpaid, $\$ 1.60$; Not prepaid, $\$ 1.50$.

\section{GRAFTING WAX}

Trowbridge's Grafting Wax has been on the market for over fifty years. It is the oldest and best on the market.

Postpaid, 1/2 lb. Cake 35c. 6 Cakes $\$ 1.65$.

Not prepaid, $3 / 2$ lb. Cake, $30 \mathrm{c} ; 6$ cakes $\$ 1.50$. 


\section{ORCHARD, LAWN AND}

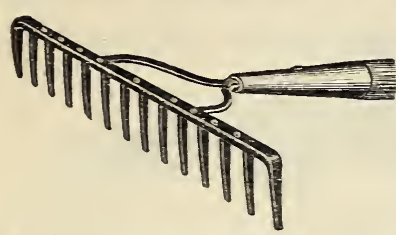

G A R D E N

RAKE-BLUE

GRASS No. 14

-Best quality

steel. The teeth

a re made of

polished steel

in pairs solidly

riveted to the

channel st e e l

head. The end teeth are crimped, which prevents their bending sideways. Made with wrought steel braced tang, making it the strongest and most durable rake on the market. Straight grain white ash handle. Not prepaid, $\$ 1.25$.

GARDEN RAKE-CICLONE No. 14-Solid

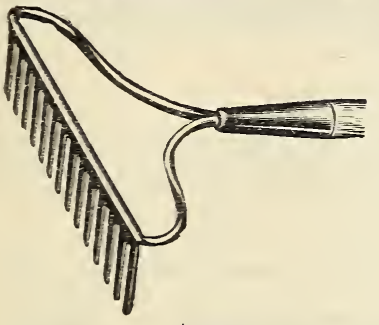

bow, head and

teeth forged

from one piece

of steel, bonze

finish. $51 / 2$ foot

straight grain

white ash

handle.

$\mathrm{N}$ ot $\mathrm{P}$ re-

paid $\$ 1.00$

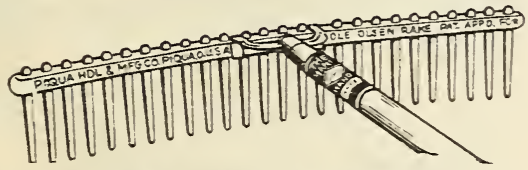

WOOD LAWN RAKE-Wood head, teeth and handle: malleable socket and lugs; socket fastened to head by two lugs that grip around the head. Straight grain white ash handle. Length of head 23 inches; 26 teeth $3 \frac{11}{4}$ inches long. This is a splendid rake to use on very fine smooth lawns, but is not adapted for rough ground. Not prepaid $\$ 1.00$.

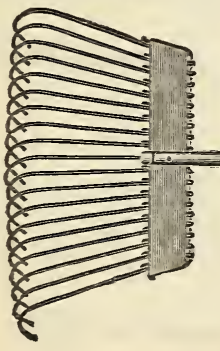

BRUVIE RAKE-JAP PANNED STEEL, flexible finger, flat teeth slightly bent. Hardwood handle 48 inches long. ....... pot prepaid $\$ 1.00$.

BRLME RAKE-BAMBOO-Not prepaid 50c.

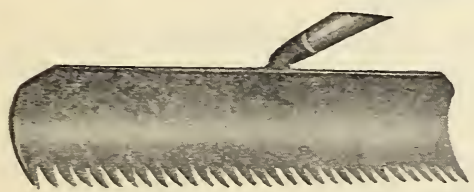

DANDELION RAKE P. E. 16-Uuequalled for removing yellow dandelions. When it is pulled across the lawn, the stems, leaves and blossoms are wedged between its teeth and easily pulled out. It is also a first class rake for general work. Not Prepaid, \$1.00.

ANY RAKE POSTPAID 25c EXTRA.
GARDEN TOOLS-Cont.

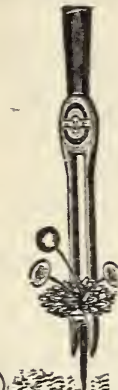

\section{The "Out-U-Kum" Weed Puller}

\section{AN ENTIRELY NEW PRINCIPLE}

A slight Push and Pull thoroughly loosens the surrounding soil and removes not only the weed, but the entire root. Indorsed by New York State Agricultural Experiment Sta. tion. A thoroughly practical tool that does the trick. Total length $3 \mathrm{ft}$. Postpaid 85c; Not prepaid \$75c. -The result of 40 years of methods for exterminating moles. In them are combined the best features of all former devices. Reddick Mole Traps are recommended by golf experts. They have been adopted by many of America's leading country clubs.

Postpaid, \$1.25.

Not prepaid, $\$ 1.00$.

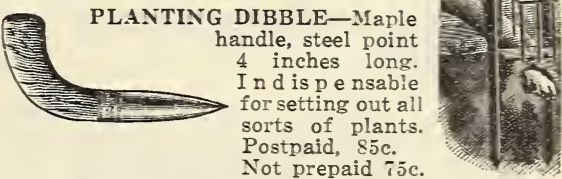

TURF EDGER No. 15i-Polished steel blade of excellent quality, b r onze finish, solid shank, 4 ft. white ash handle. $\mathrm{Th}$ is tool trims smoothly all sods and is a great labor-saver. Postpaid, \$1.75. Not Prepaid, \$1.50.

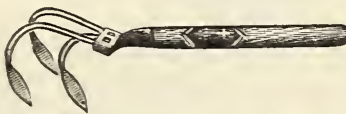

MIDGET WEED. ER-Has a nineinch handle and is designed for cultivating flowers, small shrubbery, etc., where the most careful hand work is required. It is the ideal implement for the thousands of women who tend a small garden.

Postpaid, 60c; Not Prepaid, 50c.

NO. 33-3 PRONG CULTIVATOR-Same as the Midget but with 4 foot handle.

Postpaid, \$1.10; Not Prepaid, Sj̄c.

MAGIC WEEDER No. 0.M.-Four bright heary steel wires are securely mount-
ed in black ebonized handle;
ened in. bright steel blade fast-
ting large weeds, ete. for entusefulness. Postpaid, 55c. Not Prepaid, 50c.

LAWN RAKE No. P24-Steel wire teeth rakes

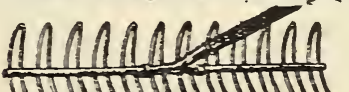
have always been particularly suitable for raking lawns. They stir the soil around roots of grass without digging up or disturbing young seedlings of the law's. Not Prepaid, 75e. 


\section{ORCHARD, LAWN and GARDEN TOOLS-(Cont'd)}

FLORAL SET No. BF3-Composed of hoe, shovel

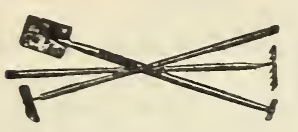
and rake. The handles are short, making them particularly adapted for working in flower beds or children's gardens.

Postpaid, \$2.25.

Floral Set No. BF3.

Not Prepaid, $\$ 2.00$

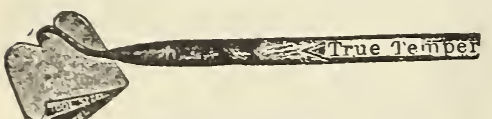

GARDEN HOE (Pine Knot)-Best quality steel blade, polished; fitted straight grain white ash handle thoroughly seasoned. Postpaid, \$1.25. Not Prepaid, $\$ 1.00$.

GARDEN HOE (Cyclone)-Same style as "Pine Knot" hoe illustrated above but made of cast steel. Straight grain white ash handle.

Postpaid, $\$ 1.00$. Not prepaid, $75 \mathrm{c}$.

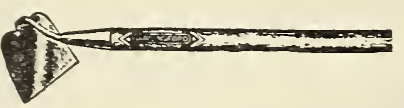

LADIES' HOE-First quality steel, polished, gold bronzed shank and ferrule, straight-grained white ash handle. A durable hoe of light weight for the garden and flower culture.

Postpaid, $90 \mathrm{c}$. Not prepaid, $75 \mathrm{c}$.

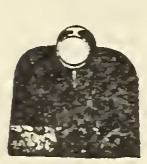

UNHANDLED EYE HOE-

Finest quality crucible steel; can be filed or sharpened; seven inch blade.

Postpaid, 90c; Not prepaid 75c. With handle, Postpaid \$1.25. Not Prepaid, $\$ 1.00$.

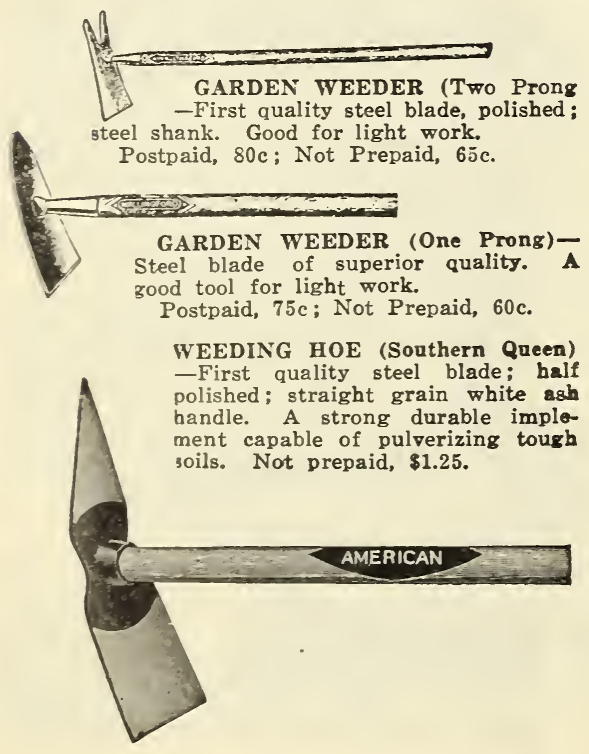

GARDEN MATTOCKS

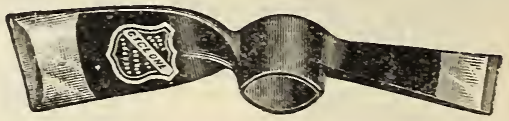

CYCLONE NO. 322-Solid cast steel body and bits; japanned body; polished tempered bits. Complete with hickory handle $\$ 2.00$.

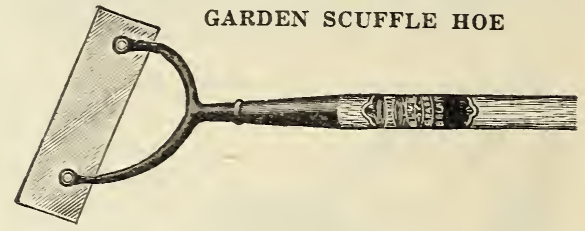

Blade $21 / 2 \times 8$ inches. Sharpened on both long edges. $5 \mathrm{ft}$. handle permits the tool to be pushed ahead and pulled back without lifting from the ground.

Not prepaid $\$ 1.35$.

POTATO HOOK (4 tines)-Broad oval tines

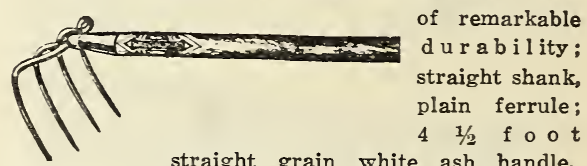
Price, No, straight grain white ash handle.

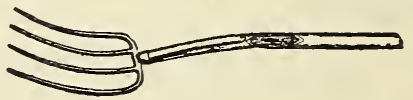

PITCH FORK - Strap ferrule; gold and blue finish; straight grain white ash handle. We offer only one fork; a superior quality in steel; tines 10 inches long; spread 8 inches wide; $41 / 2$ ft. handle. Postpaid $\$ 2.00$; Not prepaid $\$ 1.75$.

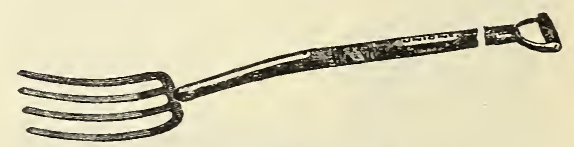

SPADING FORK-Fine bronze finish: angular steel tines of first quality; straight grained white ash handle. This tool is indispensable to all gardeners in preparing hotbeds, etc., for small seeds. Postpaid $\$ 2.00$; Not prepaid, $\$ 1.75$.

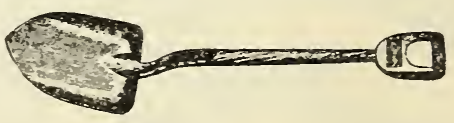

SHORT HANDLE SHOVEL-Extra cast steel ; plain back socket strap; straight grain white ash handle. Used for dirt, coal, manure, etc.

Postpaid $\$ 2.25$; Not prepaid, $\$ 2.00$.

Can furnish this shovel with square point at same price.

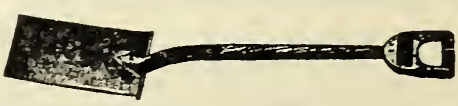

SHORT HANDLE SPADE-Square point, polished; $12 \mathrm{in}$. blade length, $71 / 2$ in. width; handle best white ash 27 inches long.

Postpaid $\$ 2.25$; Not prepaid $\$ 2.00$. 
ORCHARD, LAWN AND GARDEN TOOLS-Cont'd.

\section{GRASS HOOK}

No. 3-With pa-

tented offset. Swings perfectly in the hand with little muscular effort. Forged cut-

lery steel. Temp-

lery, steel. Temp-

ered, ground sharp
and whetted. Postpaid, 85c; Not Prepaid, $75 \mathrm{c}$.

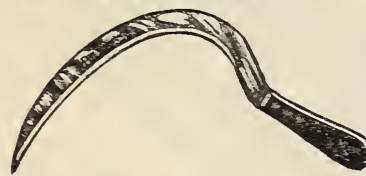

GRASS HOOK No. 2 - Forged crucible steel, carefully, tempered, ground sharp, ready for use.

\section{BIG INDIAN}

GRASS HOOK ... Scythe pattern. Tempered crucible steele blade. Heary aluminum bronzed $\mathrm{m}$ a 1 le able shank. Corrugated handle. Postpaid $85 \mathrm{c}$. Not prepaid $75 \mathrm{c}$.

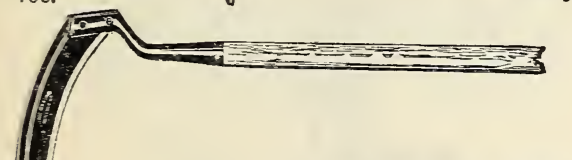

GRASS HOOK No. 6-Long handle, (43 inches) grass hook, 12 inches; erucible blade, tempered and gronnd.

Postpaid, \$1.50. Not Prepaid, \$1.25.

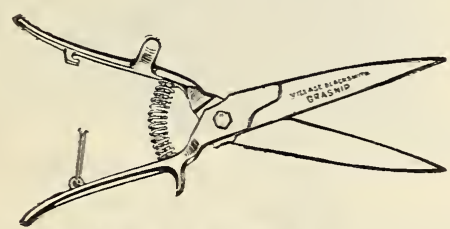

GRASNIP NO. 1

A practical all-round shear, for grass, vines, light shrubbery, etc. Ground cutlery steel blade with long cutting edge. Malleable red baked enameled handles; 13 inches over all.

Postpaid, \$1.10. Not prepaid, \$1.00.

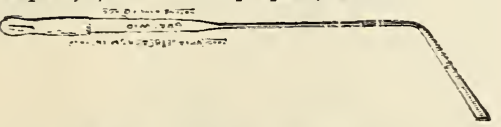

\section{GRASWIP NO. 160}

Made of forged tool steel. Cuts with forward and backward swing.

Postpaid, \$1.15. Not prepaid, $\$ 1.00$.

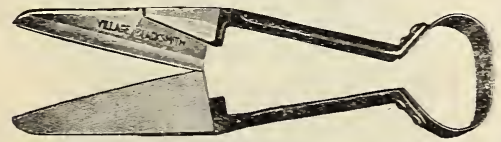

GRASS SHEAR No. V52-Trowel shank. Cutlery steel. 6 in. blade. Green enameled handle and spring. Full polished edges.

Postpaid, $85 \mathrm{c}$. Not prepaid, $75 \mathrm{c}$.

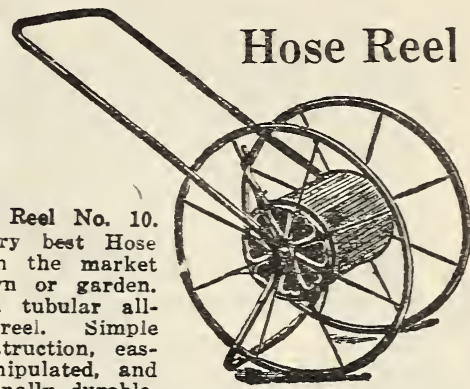

Hose Reel No 10. The very best Hose Reel on the market for lawn or garden. It is a tubular all metal reel. simple in construction, easexeeptionally durable.

The corrugated iron

drum is 9 inches in diameter; the wheels are $211 / 2$ inches in diameter; capacity, $100 \mathrm{ft}$. of hose. Do not wear the hose out dragging around on the ground. The reel keeps it clean and makes the best of care simple. Price, $\$ 5.00$.

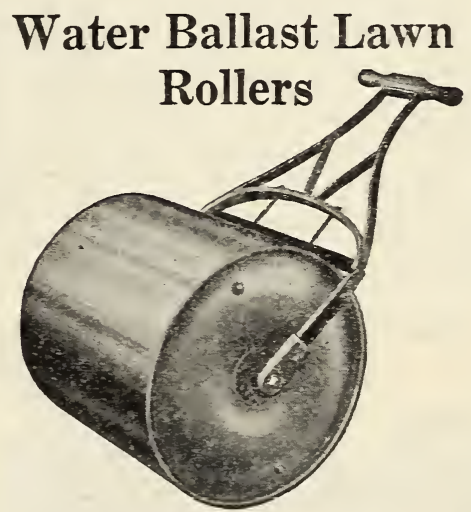

Buch Water Ballast kullers have high carbon steel axles and roller bearings. The eleetrically welded steel drum may be filled with water or sand to increase the weight. It is the most satisfactory roller on the market. It is durable and strong; can be made any weight up to eapacity of individual roller, and is easy to handle.

\begin{tabular}{c|c|c|c|c|c}
\hline & & \multicolumn{4}{|c}{ WEIGHTS } \\
\hline No. & Dis. & Length & Empty & $\begin{array}{c}\text { Filled } \\
\text { with } \\
\text { Water }\end{array}$ & PRICE \\
\hline & In. & In. & \multicolumn{1}{|c|}{ Pater } \\
\hline 601 & 14 & 24 & 70 & 175 & $\$ 17.00$ \\
602 & 18 & 24 & 85 & 265 & 20.00 \\
603 & 24 & 24 & 110 & 420 & 23.00 \\
604 & 24 & 32 & 130 & 566 & 26.00 \\
\hline
\end{tabular}

\section{TOBACCO KNIFE}

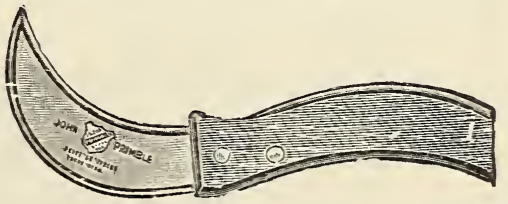

No. 3Pt.-Crucible steele blade $3 \mathrm{t} / 2$ inches long with double cutting edge. Curved handle 6 inches long. Postpaid $60 \mathrm{c}$; Not prepaid $50 \mathrm{c}$. 


\section{PENNSYLVANIA LAWN MOWERS}

Pennsylvania Lawn Mowers are the result of many years of scientific study, combined with practical knowledge of many and varied conditions under which they may be used. It is known everywhere as the lawn mower of quality. Let this quality solve the ever perplexing troubles of a smooth running and even cutting machine. Pennsylvania Junior Ball Bearing

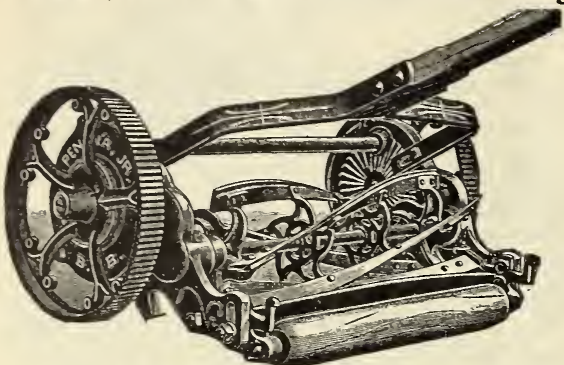

The Pennsylvania Junior has all the good points that a high grade mower should have and some features that make it the most perfect grass cutter in the world. Its self-sharpening features alone will make it worth its cost to the user, as it will save this expense until the blades are worn out, in average use a dozen years or more.

Blades: Five crucible tool steel, oil hardened and water tempered. Gears: A triple set on each side. Wheel Base extra long, cuts smoothly over uneven ground. Wheels 10 inches; open spokes. Bottom Knife: Raised edge of tempered, crucible tool steel. Height of Cut: $1 / 4$ to $15-16$ inch. Will cut grass 6 inches high.

Price 17 in., $\$ 30.00 ; 19$ in. $\$ 33.00$.

Great American Ball Bearing

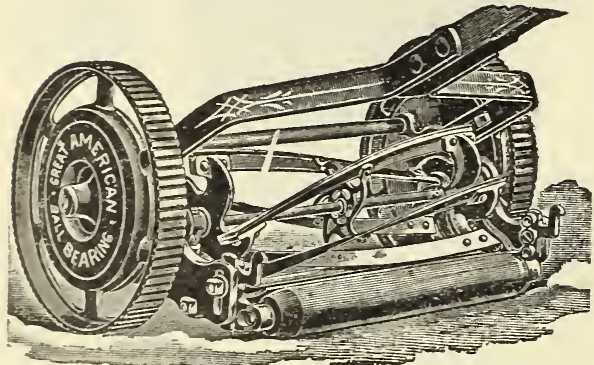

The Great American Ball Bearing is the best all-around mower of its type in the world. The perfectly-fitting ball cups and cones insure an easy running machine.

Blades: Five crucible tool steel, oil hardened and water tempered. Gears: Double; one in each drive wheel; cone and cups, hardened tool steel ; extra large balls of highest quality. Wheels: 10 inches. Bottom Knife: Self-sharpening; raised edge; crucible tool steel, insuring long service. Height of Cut: $1 / 2$ to $1 \frac{1}{2}$ inches, will cut grass 6 Inches high.

Price 17 inch $\$ 22.50 ; 19$ inch $\$ 25.00$.

Delta Ball Bearing

Best value in a low priced ball bearing mower. Blades: Four crucible tool steel, hardened and tempered. Gears: Internal: one in each wheel, Bearings; Full "Pennsylvania Quality" bearings. Wheels: 8 inches: spoke rim. Parts: Malleable and cast: accurately machined to insure noiseless service. Bottom Knift: Enos natent: self sharpening: tempered spring steel. Height of Cut: $1 / 2$ to $11 / 4$ inches. Will cut grass 5 inches high. Price, 16 in. $\$ 12.00$.

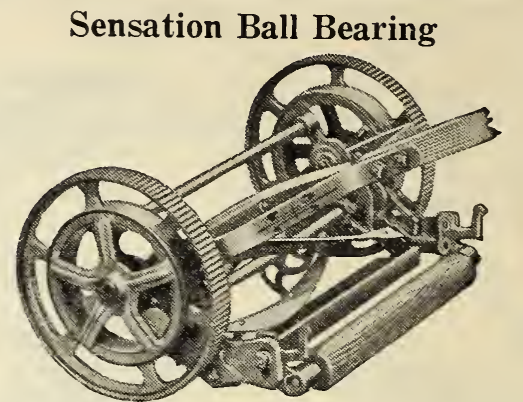

The SENSA'IION is one of the latest additions to the Pennsylvania line of mowers and answers the need of a high grade mower at a moderate price. It is handsomely finished in gold touched up with blue. 9 inch wheels, $51 / 2$ inch cylinder, 4 crucible steel blades, automatic spring adjustment on cylinder cones. Height of cut $1 / 2$ to $11 / 2$ inch; will cut grass 5 inches high.

Price 14 inch, $\$ 10.00$.

\section{Wm. Penn Ball Bearing}

The WILLIAM PENN is practically the same mower as SENSATION except it has five blades and a sixteen inch cut. For a large lawn it is worth the $\$ 2.50$ difference in price.

Price, 16 inch, $\$ 12.50$.

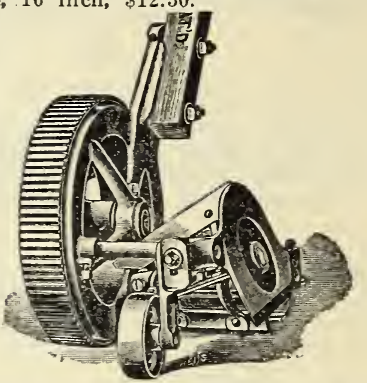

\section{Pennsylvania Undercut}

\section{B. B. Trimmer}

The unique construction of the undercut trimmer permits cutting, not only close up to a wall, fence, tree, etc., but it will get the grass under a fence or rock-cut bass of tombstones, house foundations, and other places hitherto out of reach of anything but hand shears.

The slanting side plate and conical cylinder make it possible to cut all grass left by the regular style of lawn mower; $91 / 2$ in. drive wheel ; 4 blade cylinder. Width of Cut: 51/2 inches. Price, $\$ 12.00$.

\section{Grass Catcher}

A metal bottom catcher made of finest quality, extra heavy white duck with heary galvanized wire frame and adjustable steel hooks to fit any size mower. Not prepaid $\$ 1.50$.

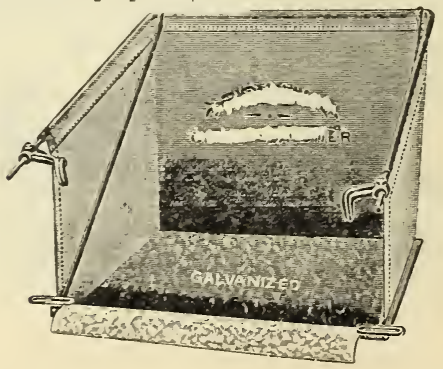




\section{BUCKEYE INCUBATORS-The Perfect Hatchers}

The successful poultry breeder is the man or woman who has learned by experience, and when you find thousands of such breeders using a certain article year after year, you must be convinced that they have found that article to be absolutely satisfactory or they would not be using it. And when the article in question happens to be an incubator, the machine on which they must depend for the production of all the chickens they raise, it is a foregone conclusion that they could not be successful unless the incubators they are using are producing the highest percentage of the highest grade chicks, the kind of chicks that enables them to perpetuate their stock and turn their product into profit.

Over 500,000 satisfied users represent the proof that we offer in support of Buckeye superioritylittle breeders, big breeders, beginners, expertsbreeders that include every class from boys and girls with a little 65 -egg machine up to the tremendous poultry plants with capacities of 50,000 eggs and more, all uniting in the same verdict. Catalog sent on request.

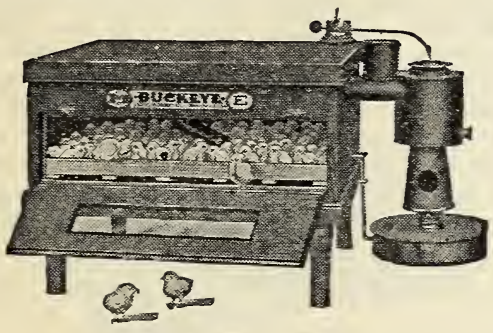

Style "E," No. 14.

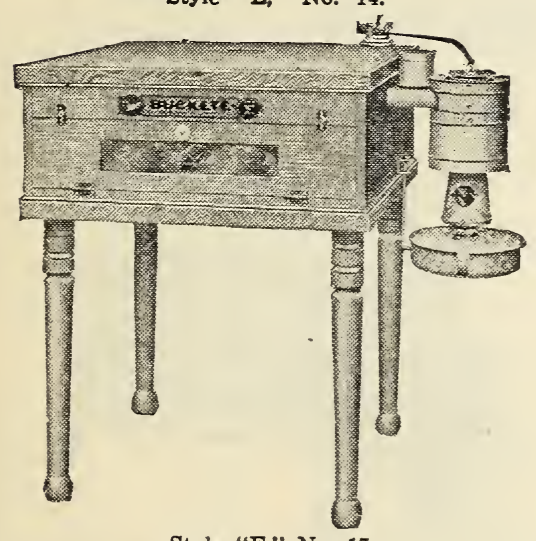

Style "E," No. 17.

Prices Of Style "E" Incubators

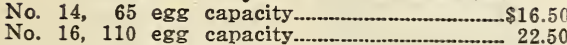

No. 16, 110 egg capacity...................................... 22.50

No 16 and 17 equiped with automatic turning trays.

Style "E" Incubators are low in price and at the same time give universal satisfaction. Hundreds of poultrymen in Western North Carolina are ready to vouch for this superior low-price incubator.

Incubator Thermometers

Price, postpaid $\$ 1.00$

Catalog of Spare Parts will be furnished Buckeye owners on request. Complete hine of repair parts carried in stock.

\section{Buckeye Standard Incubator}

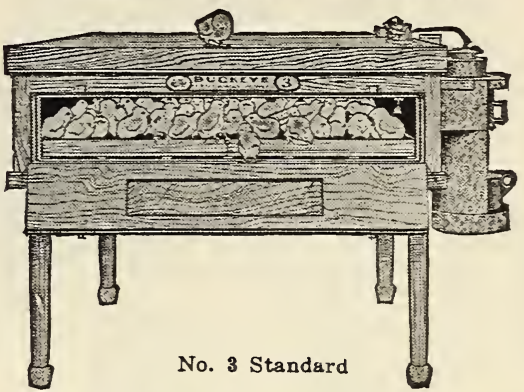

Buckeye "Standard" Incubators are equipped with every desirable device that could possibb add to the efficiency of an incubator. Only the best of materials are used and each machine $b$ inspected by the National Board of Insuranes Underwriters before they leave the factory. It requires no artificial moisture, will operate satisfactorily in any climate, and requires no attention to the regulator from the time a hatob is started until it is finished.

It is not necessary to have any previous experience to operate a Buckeye. The entire Buckeye system is so simple that a boy or girl can operate it as satisfactorily as an experienced operator. Buckeye Standard Incubators are equipped with every desirable device that can possibly be added to an incubator. The bis breeders say that there is nothing left undone, nothing to be wished for, in the "Standard." Each machine carries Underwriter's Guarantee.

\section{Prices Buckeye Standard Incubators}

No.1, 120 egg capacity............................... \$ 30.00 No. 2,175 egg capacity ………...................... 35.00

No. 3, 250 egg capacity …................................... 46.50

No. 4, 350 egg capacity........................................ 55.00

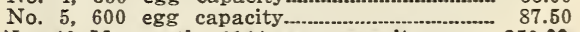

No. 40 Mammoth, 1144 egg capacity__.__ 250.00

All standard incubators equipped with automatic turning trays.

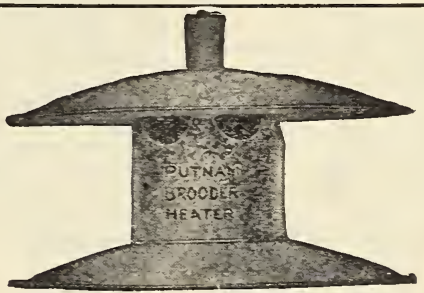

Putnam Brooder Heater

A practical and inexpensive 60 chick capacity brooder heater. Burns a minimum amount of oil and requires filling but once a week. The other materials required to install a Putnam outfit are any sort of packing box such as a shoe box, one sixth yard of oil cloth and a few nails. Full instructions as to how to construct the outfit and operate the brooder are furnished with every Putnam. Descriptive folder sent on application.

Postpaid, \$4.75.

PUTNAM WICKS (Wire Wrapped)-Postpaid, $20 \mathrm{c}$ each, 5 for $75 \mathrm{c}$. 


\section{BUCKEYE BROODERS}

\section{Blue Flame Brooder}

Burns oil and is easy and convenient to operate. Gives at all times aniform heat. As there are no cur tains on these brooders, there is always an abundant supply of fresh air, which baby chicks need as much is heat.

Nos. 80 and 81 are termed "Warm Climate" brooders and are equipped with the same size burner as No. 27A instead of the Giant Burner supplied with No. 28A and 29A.

No. $27 \mathrm{~A}, 200$ chicks.......................... $\$ 16.75$

No. $2 S A, 350$ chicks..............................\$19.50

No. $29 \mathrm{~A}, 500$ chicks..........................\$21.50

No. 80,350 chicks............................... 17.50

No. 81,500 chicks.............................. 18.50

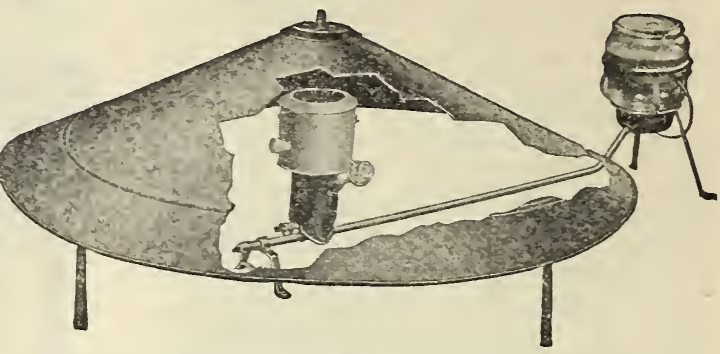

Buckeye Blue Flame "Colony" Brooders

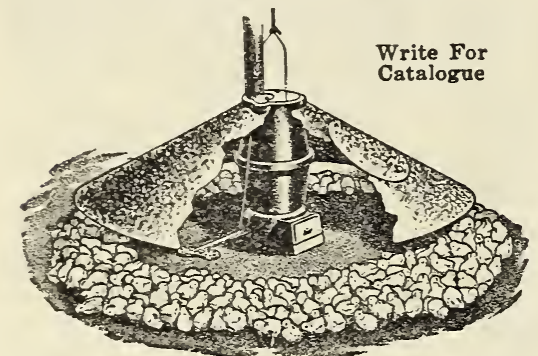

\section{Buckeye Colony Brooder}

Coal Burner Brooder that provides constant temperature, supply of pure, fresh air, plenty of exercise and no possible chance for crowding, every essential for the welfare of growing chicks, with such automatic regularity that all unfavorable conditions are eliminated. It requires little attention, is inexpensive to operate, and raises more and stronger chicks than any other brooder.

No. 117, 350 chicks.

$\$ 14.75$

No. $118, \quad 500$ chicks................................................... 18.50

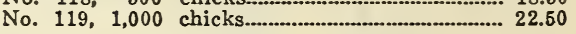

\section{POULTRY SUPPLIES}

\section{Top-Fill Cleanable Fountain}

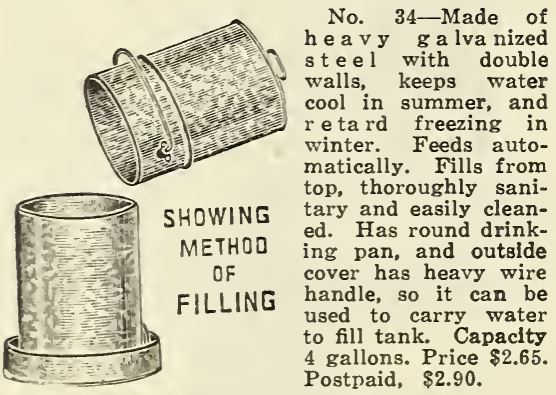

Moe's Insulated Fountains

Thick double walls packed with an efficient insulating material, which keeps the water at an even temperature in winter or summer.

Feeds the water automatically, no valves or springs. Made of heavy Balvanized iron with strong carsying handle.

No. 5, 2 gals. $\$ 2.90$ each.

No. 6,3 gals.,

$\$ 3.50$ each.

No. 7, 5 gals., $\$ 4.50$ each.

Postpaid 30c extra.

\section{Horizontal Swinging Fountain}

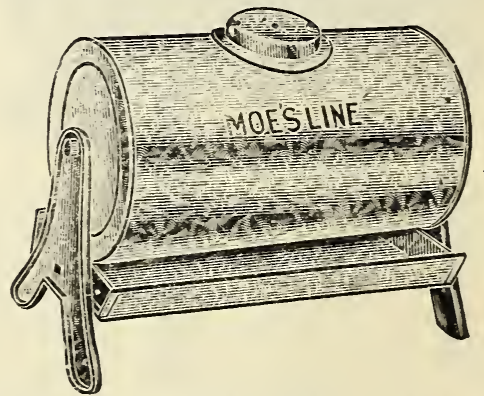

No. 43. A new type fountain of large capacity, filled through 5 inch cleaner opening at the top. Tank 12 inches diameter, 21 inches long. swings on two pivots and when inverted feeds automatically as needed. Mounted on stout $\mathrm{gal}$ vanized steel legs, with heavy drinking pan about 7 inches above the floor. Capacity 10 gallons, size of drinking pan 12 inches by 22 inches.

Price $\$ 4.00$ each. Postpaid $\$ 4.35$.

\section{Buttermilk Feeder}

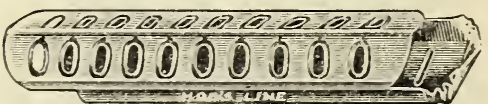

No. 137-Heavy tin plate feeding troughs witr sliding top. Easy to clean.

Price 25c; Postpaid 35c. 


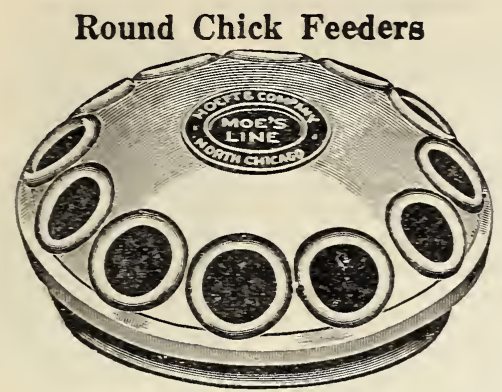

No. 12-Made of galvanized iron with 12 feed. holes. A great feed saver as chicks eannot get into it and contaminate the feed. Also used for water, $20 \mathrm{c}$ each; postpaid, $30 \mathrm{c} ; 6$ for $\$ 1.35$. No. 11-Same as No. 12 except has 8 holes, Price $10 \mathrm{c}$ each. Postpaid, $20 \mathrm{c}$ each; 6 for $75 \mathrm{c}$.

No. 132-Same style and size as No. 12 but made of bright charcoal tin plate which is not ffected by milk acids. Makes an sbsolutely afe and sanitary feeder for buttermilk and sour milk. Price $30 \mathrm{c}$ each ; postpaid, $40 \mathrm{c}$ : 6 for $\$ 2.00$

Large Capacity Chick Feeders

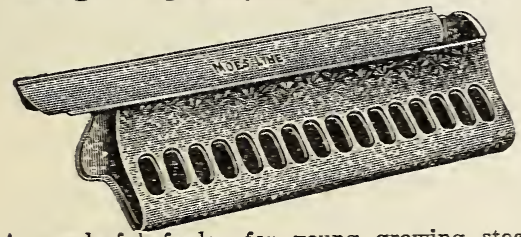

A wonderful feeder for young growing stock, and a great time and labor saver when chicks are raised in large numbers. Made of heavy galvanized iron.

Sliding top cover, easy to fill and clean, and the birds cannot roost on the cover or sides to foul the feed.

No. 140-Capacity 10 quarts. 16 openings on each side, so that 32 chicks can feed at one time. Price $\$ 1.00$ ea.; Postpaid, $\$ 1.20$.

No. 141-Capacity 17 quarts. 27 openings on each side, so that 54 chicks can feed at one time. Price $\$ 1.60$ ea.; Postpaid, $\$ 2.00$.

\section{Grit And Shell}

\section{Boxes}

Grit, shell, and chareoal, are recognized an essential part of the diet, insuring healthy fowls. They cannot be more economically supplied than in our grit and ahell boxes.

No. 45,2 compartments $40 \mathrm{c}$; postpaid, $55 \mathrm{c}$.

No. 9,3 compartments $75 \mathrm{c}$; postpaid, 9uc.

No. 90,4 compartments $\$ 1.00$; postpaid, $\$ 1.15$
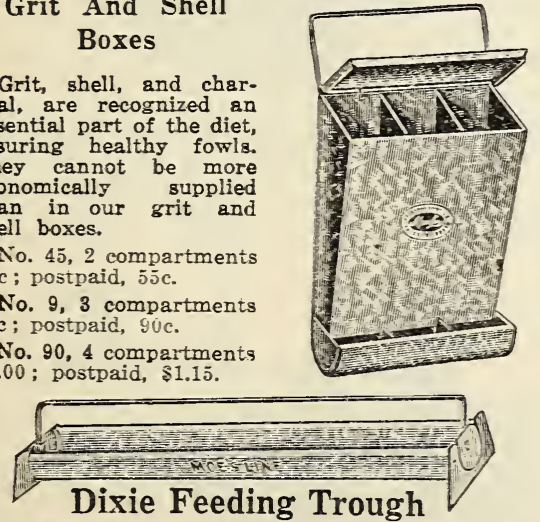

No. 460-Made of best quality galvanized steel. Easily filled and cleaned, has turned in flange to prevent waste of feed. Fitted with heavy wire top guard to keep chicks out of feeder.

Price 20c; Postpaid 30c.

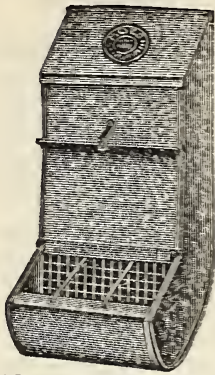

\section{Dry Mash Hopper}

The curved bottom of the hopper keeps the feed within easy reach of the birds. The gradual enlargement from top to bottom prevents clogging. The wire grid and wires running from the flange through the wire grid prevents any chance of the fowls throwing out or wasting feed. The sloping cover prevents the birds from roosting on the hopper, and when both covers are closed. it is rat and mouseproof. No. 35, Capacity 10 qts._... $\$ 1.50$; postpaid, $\$ 1.70$ No. 36, Capacity 14 qts._........\$1.70; postpaid, $\$ 1.90$ No. 13 , Capacity 22 qts........ $\$ 2.20$; postpaid $\$ 2.45$ No. 37 , Capacity 32 qts........... $\$ 2.60$; postpaid, $\$ 2.85$

\section{"Big Boy" Feeders}

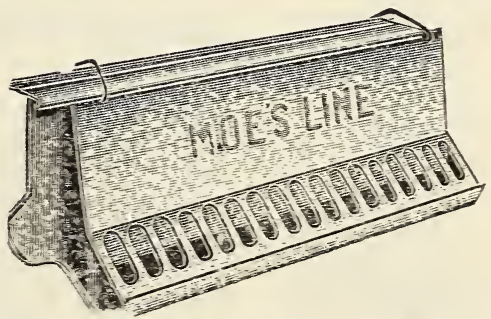

No. 160-Especially designed for growing stock. Capacity 75 pounds of mash. 34 wide openings. An excellent feeder for turkeys. Has sliding cover and is easily cleaned.

Price \$3.50. Postpaid \$3.i5.

\section{Double Feeding Troughs}

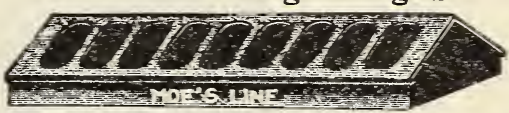

Made of best quality Galvanized Iron with center partition. Can be used for two kinds of feed. Sliding top, easy to fill and clean.

No. 58, 12 in. long......................... No. 59, 18 in. long ………-............ $40 \mathrm{c}$; Postpaid $50 \mathrm{c}$ No. 60, 24 in. long ……....................50 ; Postpaid $60 \mathrm{c}$

\section{Peerless Feeders}

For pigeons, baby chicks and growing fowl. Made of heavy galvanized iron. Suitable for either large or small flocks, as it has large capacity and thirty chicks can feed at one time. The hopper is adjustable ap or down for different kinds of mash and ieed. It can be set to feed slowly or rapidls. Bottom coneshaped so contents will not clog. Vertical feeder holes make it impossible for chicks to fowl or waste the feed.

No. 192, Capacity 10 qts., $\$ 1.35$ each; postpaid $\$ 1.55$.

No. 193, Capacity 18 qts. \$1.75 each; postpaid

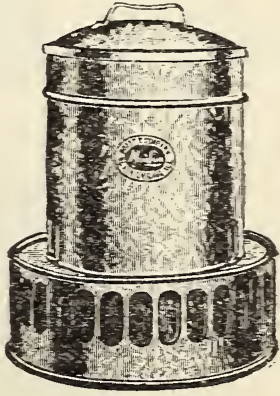
2.00 . 


\section{O. K. Warm Water Fountains}

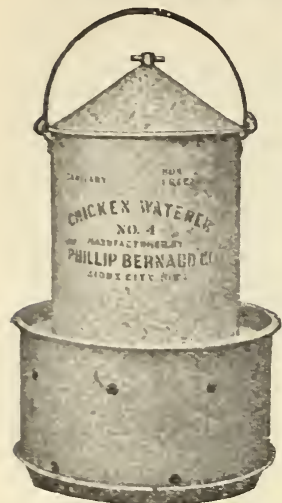

No. 4, 8 gals.

No. $10,10 \mathrm{gals}$

\section{Star Fountain}

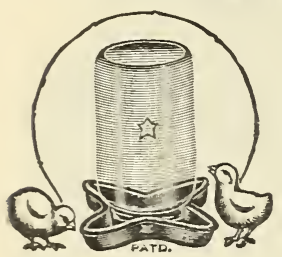

No. 133-Fits any

Mason Jar. (We do not furnish the glass jars.) Made of bright charcoal tin plate, which is not affected by milk acids. Makes an absolutely safe and sanitary feeder for buttermilk and sour milk. Postpaid, 20c each: 6 for $75 \mathrm{c}$. Not prepaid,

\section{Gallon Sanitary Fount}

No. 74 - This

style is made with permanent bot-

toms. A strong, substantia 1 wall fount at a low price. It is manufactured from galvanized iron.

The capacity is 5 gallons. Can be used in combination with Heater shown below.

Postpaid, $\$ 2.00$. Not prepaid $\$ 1.75$.

\section{No. 10 Fountain Heater}

Can be used with all styles of $f$ ou $\mathrm{n}$ ains. preven $t s$ water from freezing. Effectively 801 . ves the problem of $a$ un iform supply of fresh. clear water at all $t i \mathrm{mes}$, no matter how cold the weather.

The lamp fount or bowl holds sufficient kerosen to burn for seven days.

Price, \$1.90 each; Postpaid, \$2.10.

\section{Moe's Improved Wall Fountains}

Made of heavy galvanized iron, in 8 sizes. The covered outlet keeps out $d \mathrm{a}_{\mathrm{t}} \mathrm{and}$ dirt, and the outlet is further protected by a removable plate which prevents any floating rubbish from being drawn into reservolr.

No. 98-1 gal. $\$ 1.00$. Postpaid, \$1.15.

No. $99-2$ gal. \$1.40. Postpaid, \$1.60.

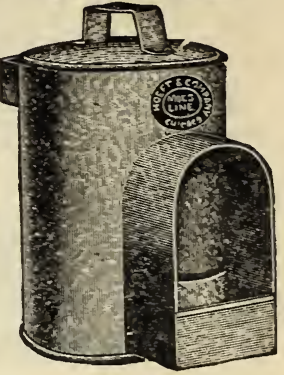

Horizontal Poultry Fountain For Baby Chicks and Growing Stock

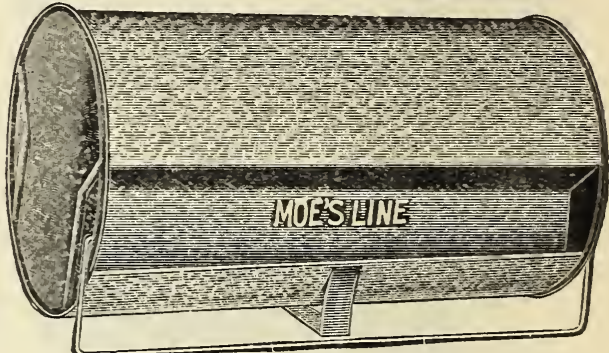

Designed for baby chicks and growing stock. Made of best quality tight coated galvanized iron, strong and substantial, the water feeds automatically and the construction provides a large drinking surface. They are solid and compact yet light in weight and easy to carry about. Have a heavy wire carrying handle. Length 12 inches, diameter $61 / 2$ inches. Capacity about 2 gallons.

No. $135,80 \mathrm{c}$ ea.; Postpaid $\$ 1.00$.

\section{Mason Jar Fountain}

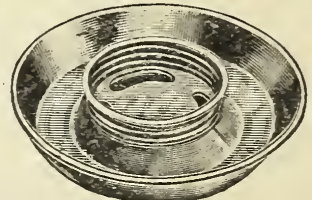

Made of heavy terne plate, a rust resisting metal, and the finest fountain of its kind on the market. No solder used in its construction.

Made in one size and fits any Mason jar in sizes 1 Pint, 1 Quart, and 2 Quarts. (We do not furnish the glass jars.) Postpaid, 20c each ; 6 for 75c. Not prepaid, 10c each.

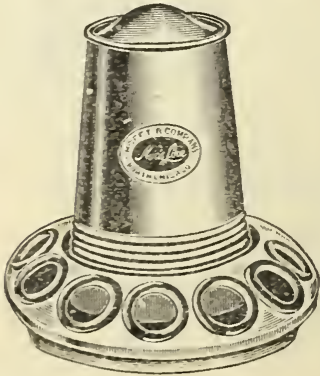

\section{Adjustable Milk}

\section{Fountain}

Magazine Feeder in tin plate. Ad. justable up and down to feed slowly or rapidly, any kind of milk or feed. Capacity about two quarts. Has 12 feeder holes.

No. $139-65$ c each postpaid, $80 \mathrm{c}$. 


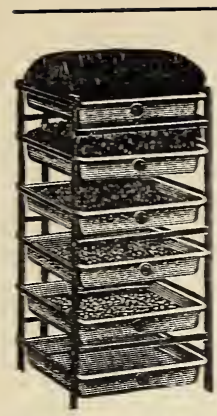

\section{Moe's Oat Sprouter}

Frame is of steel, $8 \mathrm{ft}$ high, well braced and nestly painted. Has six interchangeable heavy galvanized iron pans, 16 in. by 18 in. Five of the pans have perforated bottoms to secure the proper drainsge, and the bottom pan is solid to hold the drippings. No lamp or heater required. Best results are obtained if the sprouter is placed in 8 cellar near the furnace or in a room with a temperature of 65 or 70 desrees. Use good oats and soak them in water for about 12 hours, then fll the trays to a depth of about 1 in. Sprinkle and stir with a paddle each day until they sprout Then discontinue stirring, but continue to sprinkle daily. Postpaid, $\$ 5.80$; Not prepaid, $\$ 5.50$.

\section{Poultry Punch No. 39}

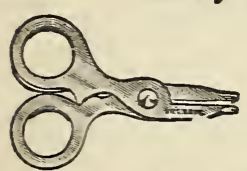

A new improved punch. scissors type. Works easily, cuts clean and does not pinch the foot.

Convenient to earry in vest pocket, and the lower end is an excellent cigar cutter.

Nickel Plated Finish, length, 316 in.

Postpaid, 40c. Not prepaid, 35c.

\section{Adjustable Leg Bands}

Made of sheet alumin. um, with large raised numbers, easy to read Irom a distance. Adjustable for any size fowl. Accurately made and quickly applied. Num-

1 to $50-1$ to $100-101$ to 200 etc up to 998 which is the highest number made
12 bands _-...\$ 0.15
100 bands
$\$ 0.65$
¿5 bands _... .25
500 bands
3.00

\section{Celluloid Leg Bands}

Colored Leg Bands are made of celluloid, in fast colors. They are of a proper temper, keep their shape, light in weight and very durable. Will not fade, and are weather proof. Quickly put on or removed, and make it easy to keep an accurate register of your birds.

Furnizic, American and Mediterranean breeds of chickens, also for baby chicks and pigeons. Four colors, yellow, green, pink and dark blue. When ordering state what size fowl the bands are required for and the color preferred.

\section{POULTRY SIZES}

12 bands _.... $\$ 0.15$

25 bands $\ldots . . . . . . .25$

50 bands ........... 40

100 bands ........... 3.25

500 bands ........... 6.00

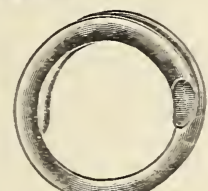

Made of white porcelain, natural in appearance, and aniform in size. Will not easily break.

They induce the hen to lay where she should - in

the nests provid. ad for her.

Postpaid, doz. 45c. Not prepaid, doz. $35 \mathrm{c}$.

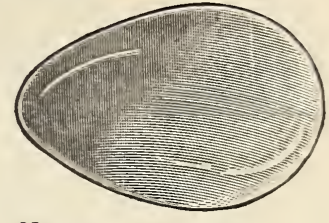

\section{Raffia (Natural Only)}

Raffia is used for many purposes, chiefly for basket making, tieing vegetables, etc. By using Diamond Dyes beautiful colors may be secured and Raffia dyed in this way can be made up into many useful articles.

Postpaid, $1 / 2$ lb. $35 \mathrm{c}$; lb., 60c: 5 lbs., $\$ 2.50$. Not prepaid, $1 / 2$ lb., $30 \mathrm{c}$; $1 \mathrm{~b} ., 50 \mathrm{c}$; 5 lbs., $\$ 2.25$.

\section{Wood Labels (Painted) FOR POTS AND GARDEN PLANTS}

Per 100 4 inch for Pots.............................................. $\$ 0.40$ .50 12 inch for Pots___ 2.00 3 inch wood, wired for trees, shrubs,$$
\text { etc. _. }
$$

If to be sent Parcel Post, please add $10 \mathrm{c}$ per 100 and $25 \mathrm{c}$ per 500 to above prices.

\section{Specialties for Stock and Dogs}

BLACKMAN'S MEDICATED SALT BRICK - The best Salt Brick on the market. A worm medicine, blood purifier, kidney regulator. Tonic and appetizer for all classes of livestock. Postpaid, 30c. Not prepaid, $25 \mathrm{c}$ ea., 5 for $\$ 1.00$; doz. for $\$ 2.25$.

BENNETT'S MILK BONE DOG BISCUIT AND MILK BONE PUPPY BISCUITEPure food for dogs, a complete scientifleally balanced food. Postpaid, 25c and $50 \mathrm{c}$.

Not prepaid, $20 \mathrm{c}$ and $40 \mathrm{c}$.

PERFECTION DOG FOOD-One of the best and most popular dog foods on the market today. Postpaid, $10 \mathrm{lbs} ., \$ 1.20 ; 25 \mathrm{lbs}$., $\$ 2.30$; 50 lbs., \$4.25. Not prepaid, 25 lbs., $\$ 2.00 ; 50$ lbs., $\$ 3.50 ; 100$ lbs., $\$ 6.50$.

WATER GLASS (Egg Preserver)-In the spring months low prices of eggs frequently play horoc with profits uriless these cheap

\section{Caponizing Tools}

Write for booklet that will give information how pour market stock may be made to yield $100 \%$ more. I is done wit Philadelphia caponizing tools.

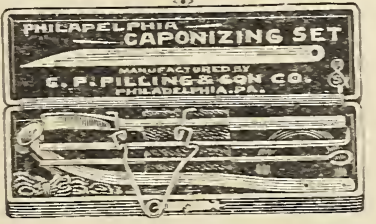

Postpaid, per set. $\$ 4.00$ eggs are taken off the market. There are two very simple solutions to the problem. One is to hatch surplus eggs the Buckeye was. Another is to put them up in Water Glass. One quart of Water Glass will preserve 15 to 20 dozen egs. Full directions on every can. Postpaid, qt. 55c; Not prepaid $40 \mathrm{c}$. PIGEON CHICK SIZE8

12 bands -... $\$ 0.10$

25 bands

50 bands

bands

00 bands ........... 1.20

00 bands .......... 2.50

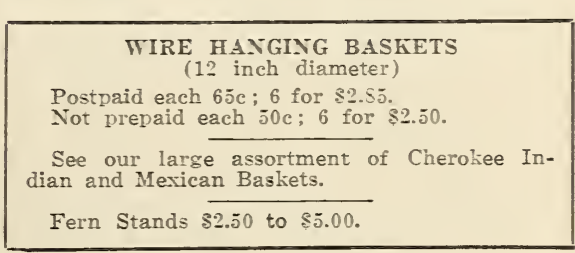




\section{MAKE POULTRY PAY A PROFIT}

Success in the Poultry Business depends to rreat extent on feeding the correct leeds, using the proper remedies the minute disease appears in the fluck, and keeping the house and nests free of vermin. Poultry raising has become a real business and must be conducted as such.

We sell a general line of Globe Feeds, manufactured by the Albert Dickinson Company, Chicago, IIl. Globe Feeds are first class in every particular, and are maintained at a uniform high standard of excellence. There are many cheaper feeds, but cheap feeds are always expensive in the long run. The prices of all grain leeds fluctuate constantly, hence it is not possible to list prices in this catalog. Prices will be ubmitted on application.

We will be glad to furnish you with booklets

GLOBE "ALL MASH" STARTING RATIONThis is a new feed, which is to be fed without Scratch Grain. This is a decidedly improved system of feeding, as the ration is balanced correctly and it is not left to the poultry raiser to proportion the scratch feed. It should be fed for the first six weeks, then begin using Globe "All Mash" Growing Ration.

GLOBE BABY CHICK SCRATCH-This is a finely crushed grain that should be fed to baby chicks with Chick Mash, when the "All Mash" Starting Ration is not used. Helps to build tissue, bone and body.

GLOBE "ALL MASH" GROWING RATIONThis feed should be fed in equal amount with "All Mash" Starting Ration from the 6 th to 8 th week and then should be fed alone until the 16th week. No Scratch Grain is needed.

GLOBE GROWING SCRATCH-This grain should be fed to growing chicks with Growing Mash when the "All Mash" Growing Ration is not used.

GLOBE EGG PRODUCER - A laying mash which is a well balanced mixture of the following feeds: dried buttermilk, fine ground meat scraps, corn gluten feed, linseed oil meal, oat flour, soy bean oil meal, corn feed meal, wheat middlings, wheat bran, fine ground alfalfa meal, bone meal. This feed should be kept before the layers at all times.

GLOBE HEN SCRATCH-An evenly balanced ration mixed from the very best grains. Should be fed with Egg Mash at all times; and with "All Mash" Laying Ration during the winter and moltIng season.

GLOBE MILK PRODUCER-One of the best dairy feeds manufactured and an enormous seller in the large milk producing sections. giving full directions about feeding "All Mash" Feeds.

A very valuable Poultry Book, published by The Albert Dickinson Company, describing Globe Feed and treating of poultry raising in general, will be mailed free of charge upon request.

GLOBE RABBIT FEED-This feed is a complete balanced ration for quick growth and better furs. It is made up as follows: dried buttermilk, coarse alfalfa meal, ground oats, crushed oats, ground barley, corn feed meal, wheat bran, linseed oil meal, bone meal, molasses, calcium carbonate and $1 / 2$ of 1 per cent salt.

GLOBE CALF MEAL-Raises fine calves to six months of age at a big saving over milk feeding method. Write for folder.

GLOBE BREEDING PIGEON FEED-A well balanced feed, made from wheat, buckwhest. kaffir cor'n, millet, hemp, and Canada field peas.

GLOBE UTILITY PIGEON FEED-Highly recommended for Growing Pigeons. It lacks sufficient quantity of Canada Field Peas for breeding Pigeons. With or without argentine corn.

FOUST'S HEALTH GRIT-A health tonic for pigeons. A mixture of salt, sea shells, rock grit, etc. Postpaid, 5 lbs., 35c; 10 lbs., 65c; 25 lbs., $\$ 1.45 ; 50$ lbs. $\$ 2.65$. Not Prepaid, 5 lbs. $25 \mathrm{c}$ : 25 lbs. $\$ 1.00 ; 50$ lbs. $\$ 1.90 ; 100$ lbs. $\$ 3.50$.

BEEF SCRAPS-Very high in protein and an essential egg producer and muscle builder. Needed especially in the winter.

CRUSHED OYSTER SHELL-Should be kept available for fowls at all times; forms egg shells. Coarse or fine: Postpaid, 5 lbs. 25c ; 10 lbs. 45c: 25 lbs. $\$ 1.00$; 50 lbs. $\$ 1.65$. Not Prepaid, per lb. $3 \mathrm{c}$; bag (100 lbs.) $\$ 1.50$.

LIME GRIT-A neecssity for both young and old stock. Don't expect your birds to grind their food with oyster shell alone. Coarse or fine: Postpaid, 5 lbs. 25c; 10 lbs. 45c: 25 lbs. $\$ 1.05$; 50 lbs., \$1.85. Not Prepaid, per lb., 3c ; bag (100 lbs.), $\$ 1.75$.

CHARCOAL - Aids digestion; purifies the blood, and generally promotes the good health and vigor of your birds. Coarse or fine: Postpaid, 5 lbs., 55c; 25 lbs., $\$ 1.75$; bag (50 lbs.). $\$ 2.75$. Not Prepaid, lb., 7c; bag (50 lbs.), $\$ 2.00$.

DON SUNG-Chinese Tablets for Egg Laying. Scientifically compounded to make a balanced tonic and regulator for hens and to stimulate egg laying. Postaid, 45 tablets $50 \mathrm{c}$; 135 tablets, $\$ 1.00$.

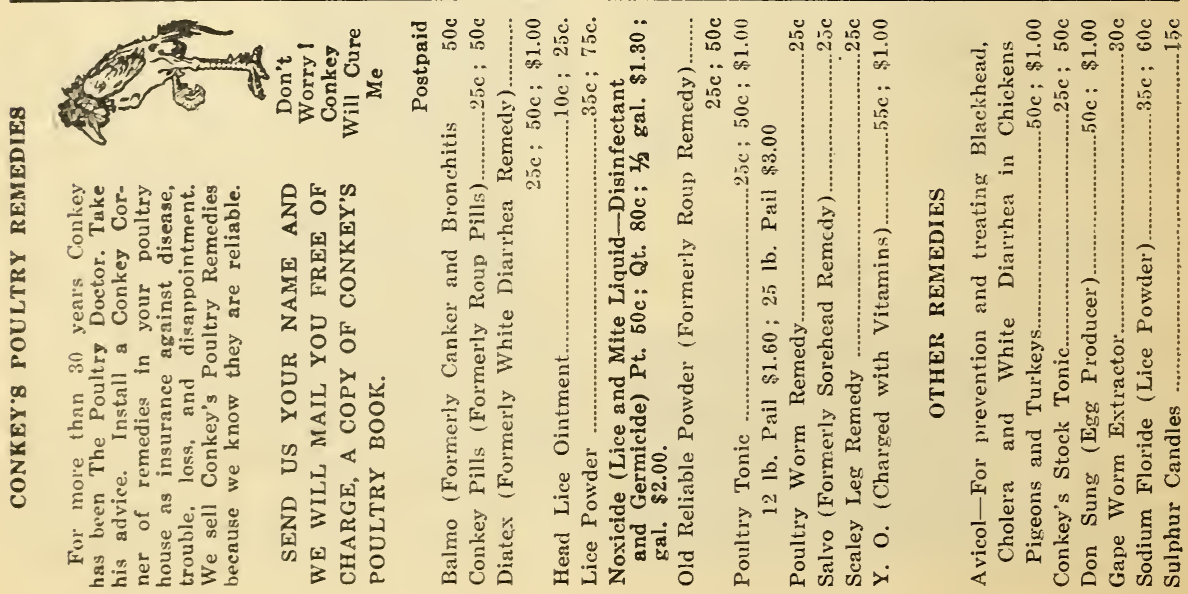


ORDER BLANK FOR SEEDS, ETC.

All prices in this catalog, except where otherwise noted, are based on customer paying transportation charges. Please see page 1 for Parcel Post rates, conditions of sale, direction for ordering, sending money, etc.

\section{ASHEVILLE SEED COMPANY ASHEVILLE, N. C.}

Please Do Not Write Here

Date Received

Date Filled

Filled $\mathrm{By}$

Shipped By

Order Number

\section{Amount Enclosed}

Check.

P. O. Money Order

Exp. Money Order.

Cash

Stamps

County

State

R. F. D.

Box

(Ladies, please prefix Miss or Mrs.; the latter using husband's initials)

Postoffice $-$

(If different from Postoffice)

Express or Freight Office

ASHEVILLE SEED COMPANY gives no warranty, express or implied, as to description, quality, productiveness, or any other matter, of any seeds, bulbs or plants they send out and they will be in no way responsible for the crop. If the purchaser does not accept the goods on these terms, they are at once to be returned, money will be refunded and no sale has been made.

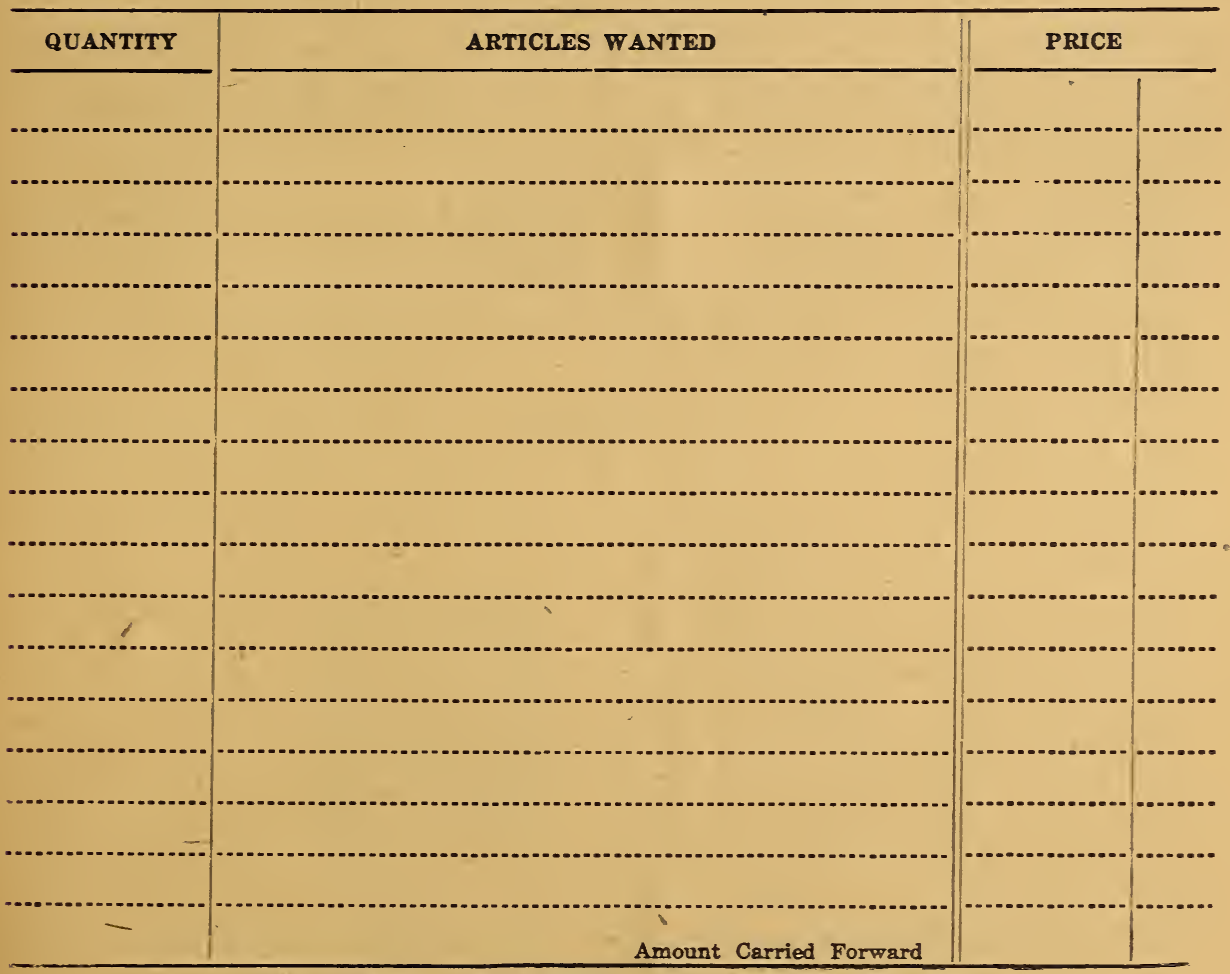


PRICES SUBJECT TO CHANGE WITHOUT NOTICE

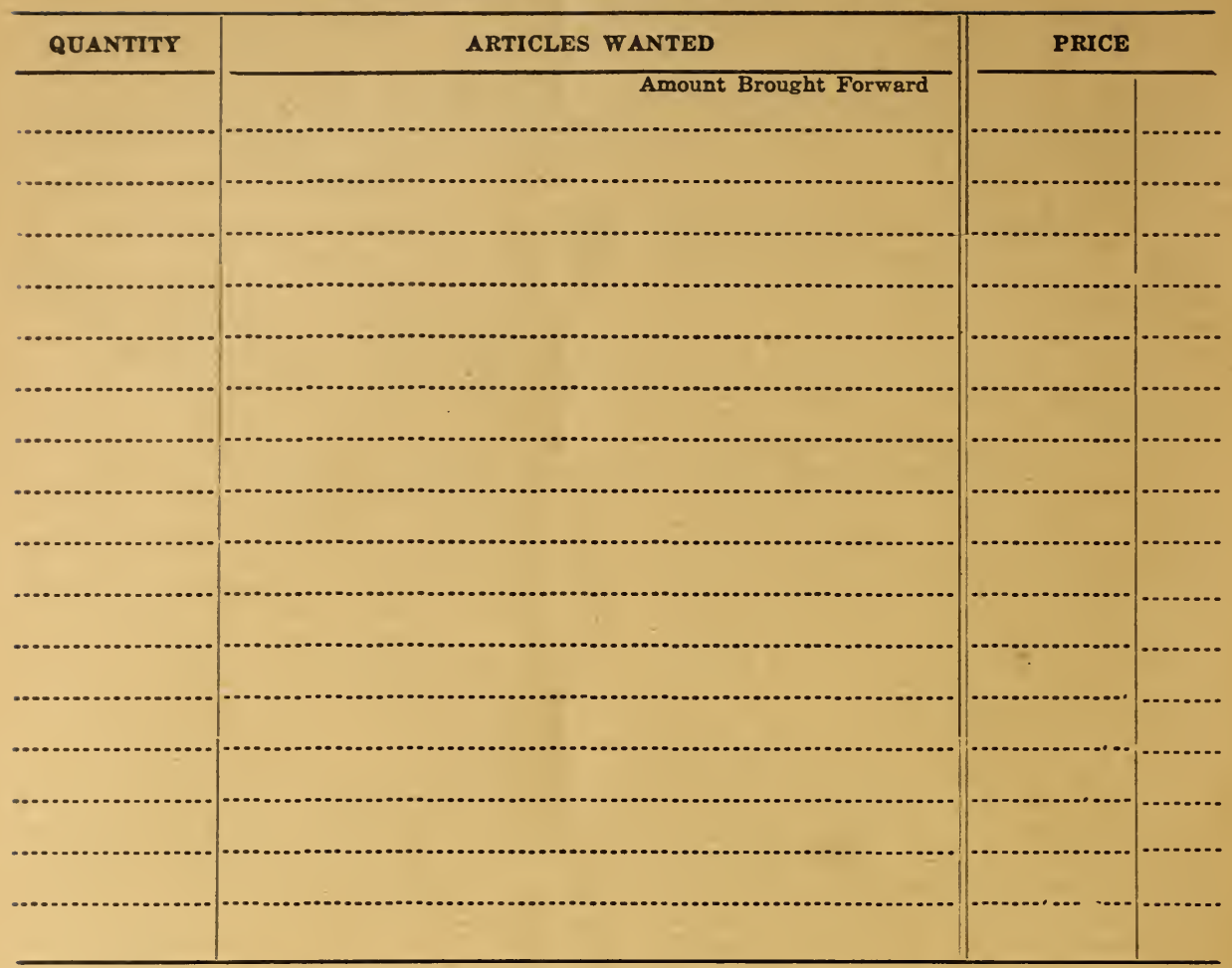

By carefully checking this list before sending your order, a great saving may be made in transportation cost, and you may also find that an important and an immediate necessity has been omitted.

$\begin{array}{llll}\text { Garden Seed } & \text { Lawn Seed } & \text { Insecticides } & \text { Garden Tools } \\ \text { Flower Seed } & \text { Bulbs } & \text { Fungicides } & \text { Orchard Tools } \\ \text { Field Seed } & \text { Fertilizers } & \text { Dusting Materials } & \text { Lawn Tools } \\ \text { Poultry Supplies } & \text { Incubators } & \text { Sprayers } & \text { Feeds, Etc. }\end{array}$

Kindly list below the names of any friends whom you think would be interested in receiving our catalog.

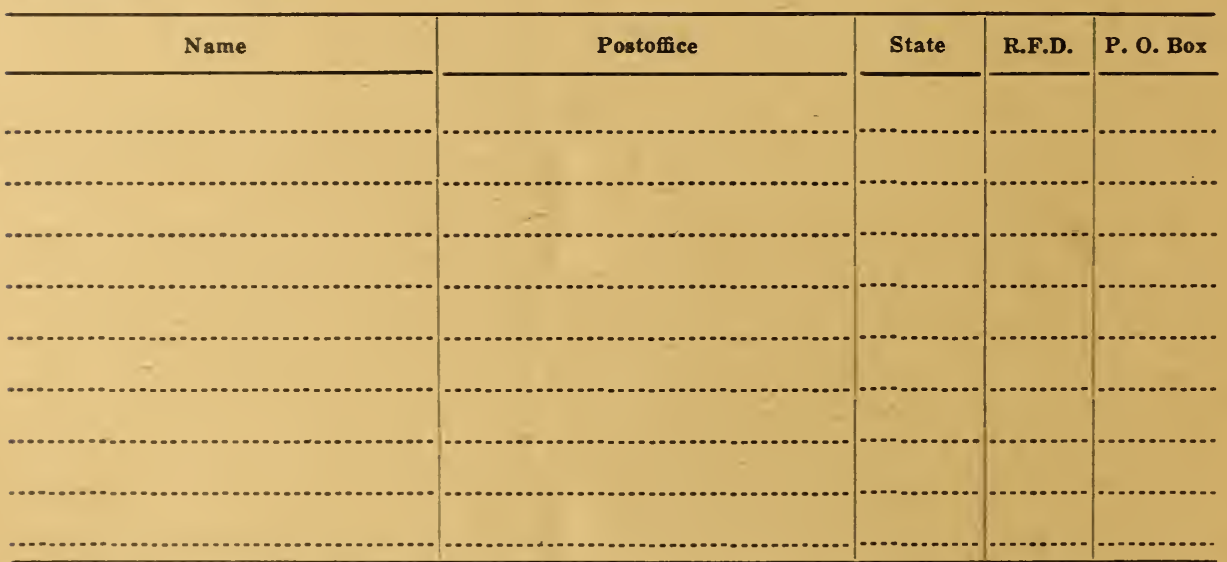


FLOWER POTS AND SAUCERS

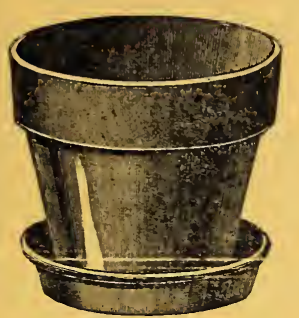

Full inside measurements. Six at dozen rate, fifty at hundred rate. Shipped by freight or express. We pack carefully but do not assume any responsibility for breakage. No clay flower pots or saucers sent by mail.

\section{STANDARD POTS}

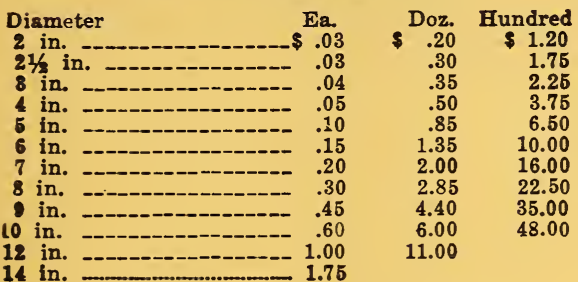

\section{FLOWER POT SAUCERS}

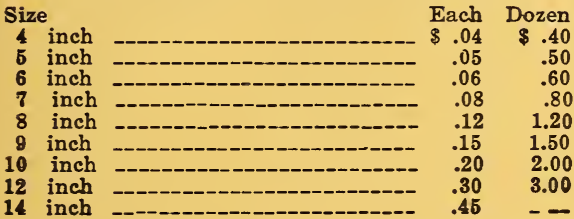

\section{NEPONSET WATERPROOF PAPER FLOWER POTS}

\begin{tabular}{|c|c|c|c|c|c|}
\hline & & Not & Prepaid & & Postpaid \\
\hline Diam. & Doz. & 100 & 1000 & Doz. & $100 / 1000$ \\
\hline $21 / 2 " \quad \ldots \ldots$ & .15 & .65 & 5.50 & .25 & 5.75 \\
\hline 8" & .18 & .85 & 7.50 & .28 & 7.85 \\
\hline 81/2" & .20 & 1.15 & 10.00 & .30 & $1.35 \mid 10.50$ \\
\hline
\end{tabular}

\section{GLASS CLOTH}

It is a substitute for glass but much cheaper and in many ways superior. It does not break like glass and it admits the valuable ultra-violet rays of the sun. Fine for hot beds, poultry bouses, scratch shed's, porches, etc.

Not prepaid, Yard 40c; 6 yards $\$ 2.25 ; 10$ yards $\$ 3.50 ; 15$ yards $\$ 5.00$.

Hot bed sash with 2 yards cloth $\$ 3.00$.

\section{CEDAR}

\section{PLANT} TUBS

These tubs will last twice as long as cypress tubs. They are highly finished with black hoops, handles and legs.

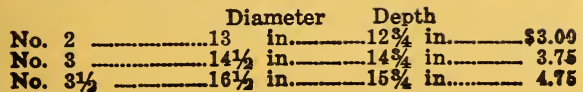

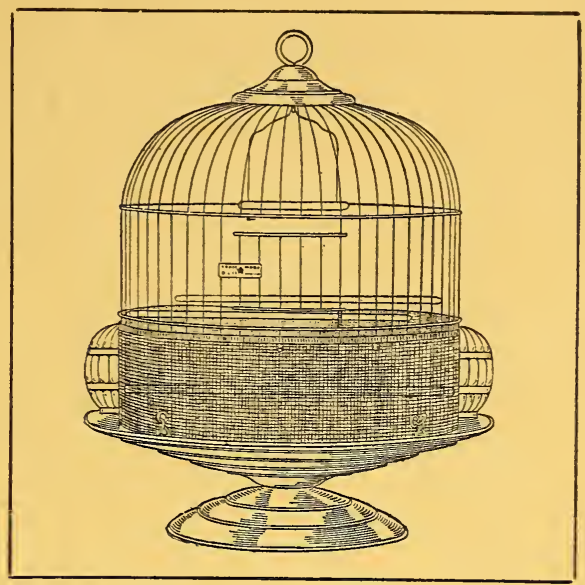

\section{BIRD CAGES}

We carry a large assortment of japanned, brass and colored cages priced from $\$ 2.00$ to $\$ 18.00$. Cage stands from $\$ 2.50$ to $\$ 9.00$. Cage illustrated above is a 3 rail brass cage, 101/4 inches in diameter. Postpaid $\$ 3.25$; Not prepaid $\$ 3.00$.

\section{BIRDS}

In the fall and winter months we handle Imported Canaries, Paroquets, Parrots, etc. Write for prices. We also keep in touch with breeders of Domestic Canaries and we are always glad to bring prospective buyers and sellers together.

\section{BIRD SUPPLIES POSTPAID}

Philadelphia Bird Seed....2 pkts. 50c: 6 for $\$ 1.25$ Mixed Bird Seed.......................2 lbs. $50 \mathrm{c}$; 5 lbs. $95 \mathrm{c}$ Mixed Parrot Seed..-.-.--.-.-....... $35 \mathrm{c} ; 2$ lb. Box. $60 \mathrm{c}$ Sunflower Seed._...................... 35c; 5 lbs. $\$ 1.25$

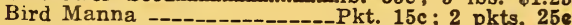
Magic Song Restorer-_-_-_Box $35 \mathrm{c} ; 2$ box $60 \mathrm{c}$ Silver or Red Gravel_------Pkt. 25c; 2 pkts. $40 \mathrm{e}$ Bird Bitters Bird Mite Powder.Mite Powder Gun Merican Leg Salve.-.-.ea, 20c Cuttle Fish Bone and Holder................... 10e Bird Coloring (Orange) Bird Moulting Pepper-_-_---_-_- pkt. 25c Bird Nesting - Bird Baths Cage Cups Cage Springs ---_---_-_- $35 \mathrm{c}$ Cage Hooks

\section{GOLD FISH AND SUPPLIES}

We carry a large stock of Gold Fish for delivery from September to April each year. The prices of these Fish range from 10 cents to 75 cents each. If Fish are to be shipped by ex. press, at buyers risk, add to price of Fish wanted 10 cents extra for bucket, holding six Fish; 15 cents for bucket holding twelve Fish. Cannot be mailed.

Fish Bowls, Crystal and Colored.........10c to $\$ 5.00$ Aquariums........................................... $\$ 30$ to $\$ 20.00$ Castles, postpaid_................. $\$ 35$ to $\$ 1.00$ Fish Food Wafers postpaid, pkt.___nc to $\$ 1.00$

Bowls and Aquariums can only be sent via express. We pack carefully but will not be responsible for breakage. 
ASHEVILlE SEED CO., ASHEVILLE, N. C.

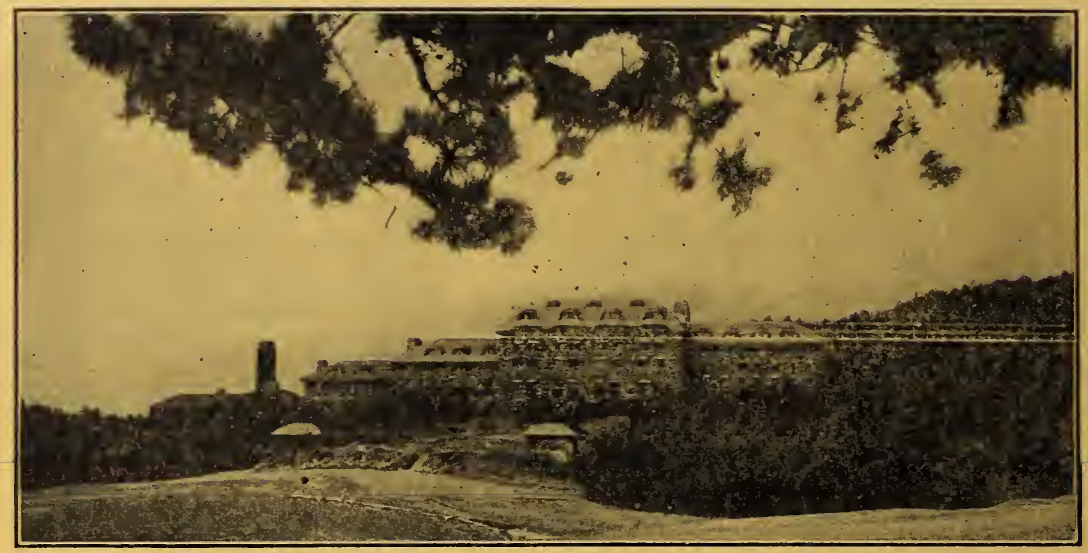

Grove Park Inn: Vigoro used on the grounds of this internationally famous institution gives results "almost like magic" according to Mr. C. R. Cook, Chief Engineer.

\section{Avoid Gardening Failures-Use Vigoro}

Successful gardening is dependent upon proper feeding. Not the old makeshift methods but with a complete plantfood containing all the elements that plant life requires for normal healthy growth.

Such a food is Vigoro. Complete, properly balanced, clean and odorless. It can be sown by hand like grass seed.

For a thick growth of healthy grass, beautiful flowers, leafy shrubs and trees, and crisp vegetables, use Vigoro.

Full directions in every bag. Get enough now for everything you grow.

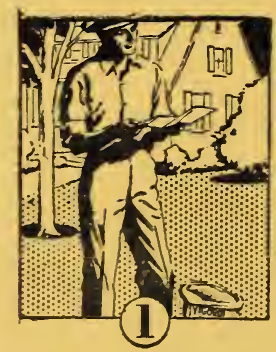

Read Simple Directions

$100 \mathrm{lb}$. bag . . $\$ 5.00$

$50 \mathrm{lb}$. bag . . 3.00

$25 \mathrm{lb}$. bag . . 1.75

$5 \mathrm{lb}$ bag . . .50

12 oz. pkg . . . 10 All f.o.b. Asheville, N.C.

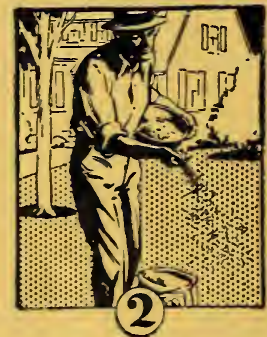

Broadcast Vigoro Evenly

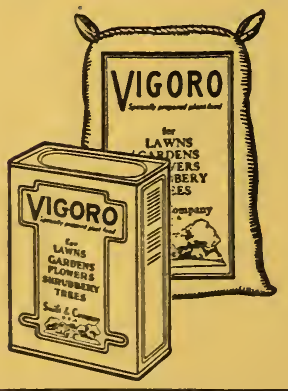

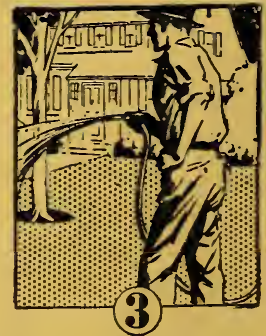

Wet down Thoroughly

A product of

Swift \& Company for lawns,flowers, vegetables, shrubs and trees. 